
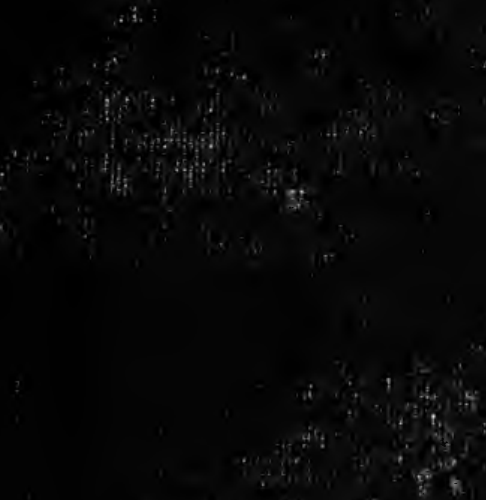


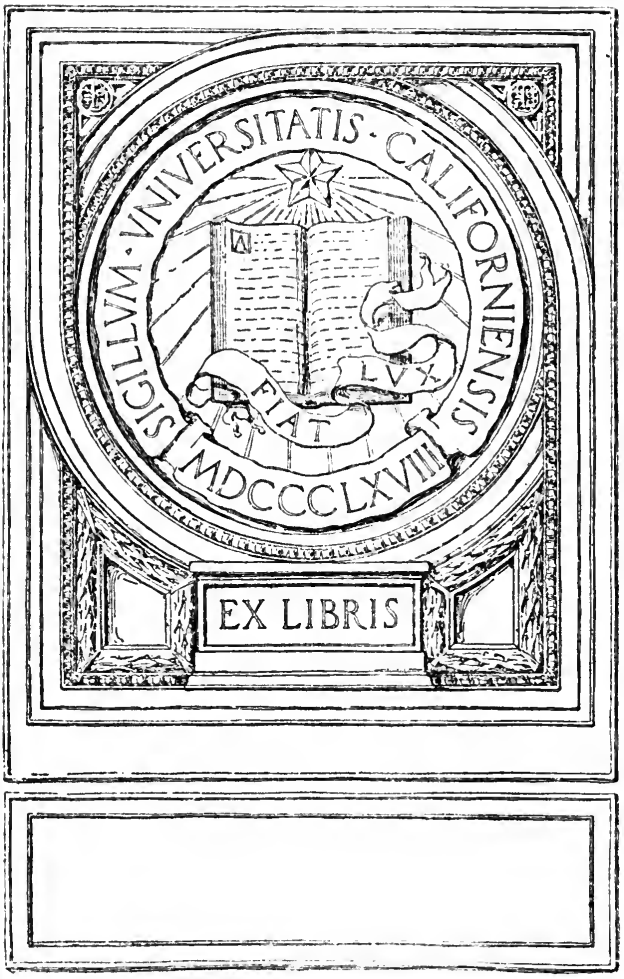



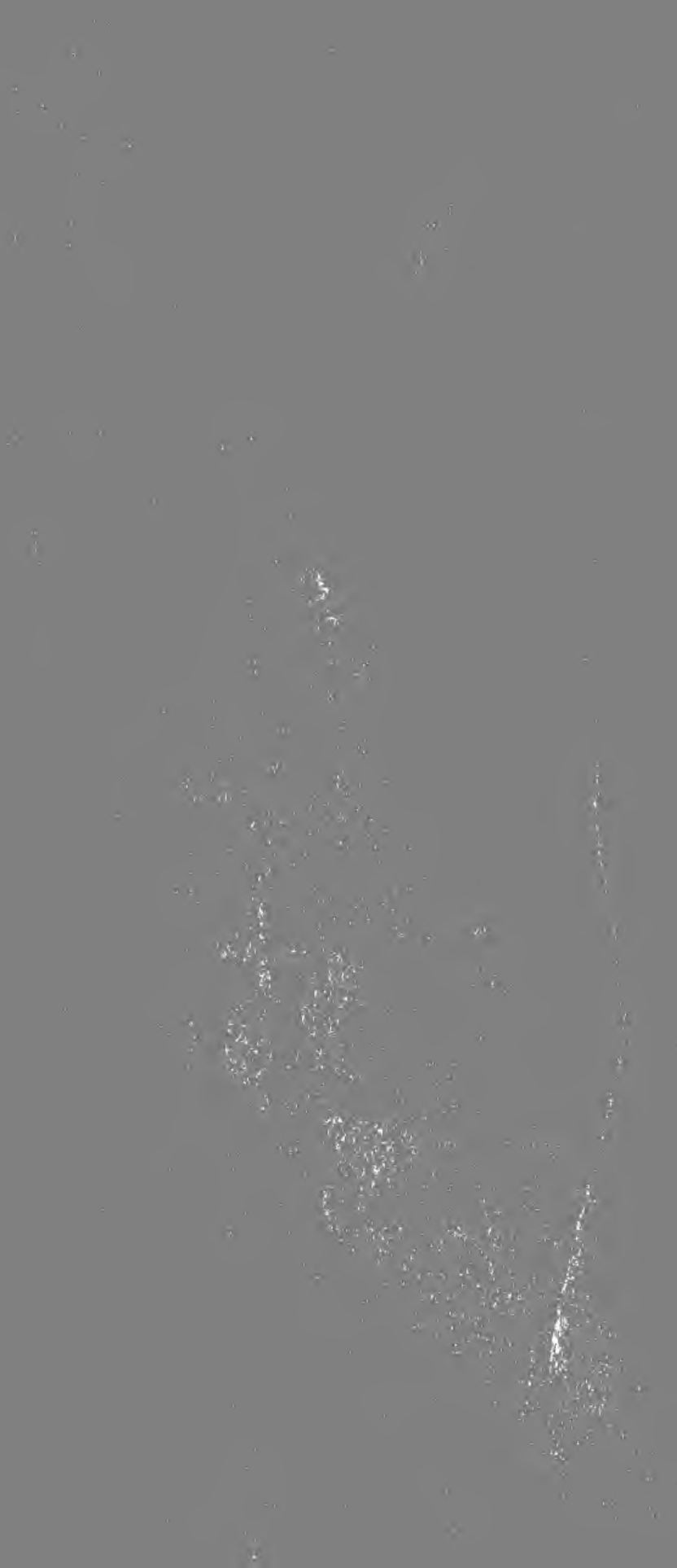


\section{MUNICIPAL ADMINISTRATION}




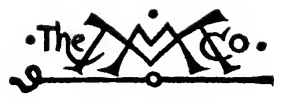




\section{UN I C I P A L}

\section{A D M I N ISTRATION}

BY

JOHN A. FAIRLIE, Ph.D.

ASSISTANT PROFESSOR OF ADMINISTRATIVE LAW UNIVERSITY OF MICHIGAN

Now Work

THE MACMILLAN COMPANY

LONDON: MACMILLAN \& CO., LTD.

1910 


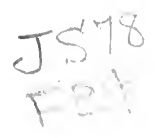

Coprrient, 1901,

Bt THE MACMILLAN COMPANY.

Set up and electrotyped. Published November, rgor. Reprinted August, rgo6 ; September, 19 ro.

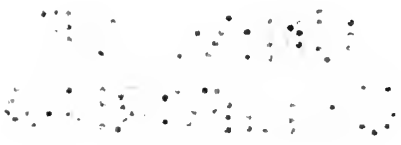

Norwood Fises⿱

J. S. Cushing \& Co. - Berwick \& Smith Co. Norwood, Mass., U.s.A. 


\section{PREFACE}

MucH has been written on various aspects and problems of municipal administration, and some brief general outlines have also appeared; but nothing has thus far been published which can claim to be more than a partial or an elementary treatment, as indeed the authors would be the first to admit. This stage of fragmentary writing has been a necessary and an important one in developing the discussion and literary treatment of a new subject of large and growing significance. It would seem, however, that the time has now come for a more comprehensive and more systematic treatise, and it is as an attempt in this direction that the writer makes bold to present this work.

The title, "Municipal Administration," probably conveys a general idea of the subject to the minds of readers. Yet such is the vagueness and uncertainty with which words are used that it will be worth while to make the conception more exact by some definition of terms. Administration is a general term with the widest range of meaning, applying to the management of any kind of business. In reference to public affairs, administration is the detailed execution of general policies, the application of laws. It is to be contrasted and distinguished from legislation, and is indeed the work of public officials, established and set in operation by legislative measures. Municipal administration is that branch of public administration intrusted to municipal officials. The duties of such officials are almost exclusively of an administrative rather than a legislative character; and for that reason the title given is preferred to the less definite term "municipal government."

It is necessary, further, to note more carefully the scope of the word "municipal." In English and American law a.

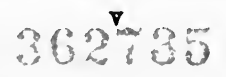


municipality is any subordinate public authority created by the central government and vested with the legal rights of a corporation. The term applies to the local authorities in cities, villages, counties, special authorities such as school and park boards, and even to incorporated townships as in Massachusetts. In this sense, municipal administration would include the whole field of local government. But the local administration of public affairs in cities or urban districts is so strongly differentiated from that in rural districts, and is, moreover, so much the more important, that, by common usage, municipal is often confined to urban or city communities, and is so used in this work. There is indeed a further restriction by which, where there are several local incorporated authorities in a city, only one (usually the most important) is called the municipal corporation; but it is impossible to recognize local variations of this kind, and municipal will be held to include all of the local public authorities in a city.

These definitions show that the book deals primarily with the cities of the world. But what constitutes a city? Legal definitions vary widely in different countries and in the different American states; and the word is often applied to petty villages as well as to metropolitan communities. Moreover, the dictionaries in their attempts to express the general meaning of the word have used phrases so vague that they fail to convey any definite idea. There are, in fact, three essential elements which must exist to form a city, and all of these must be represented in the definition : (1) the geographical fact of a definite local area on which buildings are for the most part compactly erected; (2) the sociological fact of a large community of people densely settled on the given area; and (3) the political fact of an organized local authority or authorities controlling the public affairs of the community. Combining these elements, a city may be defined as "A populous community, inhabiting a definite, compactly built locality, and having an organized public authority." This statement includes all the necessary features which go to make up a city, while omitting 
the exact details of legal definition which vary so widely. Where necessary to establish a statistical standard, the writer believes a minimum limit of twenty thousand population is about the figure at which real urban conditions come into existence; while urban communities of over one hundred thousand population may be classed as great cities.

It will be noticed that the form of definition given emphasizes the fact of population, which is the most important element and the factor most often meant when the word "city" is used. But the order of phrases can be readily rearranged to represent the secondary meanings of the word.

Cities are the mark of civilization advancing beyond the stage of self-sufficing agricultural villages. The urban community is both product and sign of the division of labor into agriculture, commerce, and industry, since an essential element of the city as here defined is the absence of agriculture in the city proper; and hence the need of trade in agricultural supplies to the city, which cannot long exist without a return trade of city products to the country.

The prime factors, too, in the development of cities are the development of commerce and industry. It is true some cities have been deliberately planted for military, administrative, or political reasons; but these cities have no stable basis or permanence as a community, and can have none until they become commercial or industrial centres. A purely political or military city, supported by contributions either from the surrounding country or from outlying provinces, may be maintained only so long as the army holds its power or the government continues at that place.

The commercial and industrial city has a much more permanent position. It obtains the sustenance for its inhabitants not by forced contributions, but indirectly from its own resources and activities. It thus has a vitality of its own, and may maintain itself for centuries, as have Damascus, Marseilles, and Cadiz. The economic bases of city life are not, however, altogether immutable. The Otto- 
man conquest, which closed the commercial routes from Europe to the East, caused the decline of Aleppo and seriously affected the prosperity of Venice. But such cases are rare; and the economic city usually persists from age to age.

It is due to the irresistible tendency of modern industrial development to mass population at trade and manufacturing centres that the nineteenth century, and especially the latter part of it, has seen the constant enlargements in the area and population of former cities and the appearance and rapid growth of new cities. In all the important countries of the world the rural district has become a town; the town a small city; the small city a large one; the large one a metropolis.

At each stage of growth the need or the opportunity for exercising new public activities in order to satisfy local wants has been felt, while at the same time progress in technical efficiency has opened the way for further additions to the functions of government. Add to this the spread of democratic ideas, which has raised the concepts of human rights and human dignity, and has thus induced public bodies to extend their activities so as to elevate the social condition and the culture plane of the lower classes. From all of these causes the scope of all forms of public activity has been broadened and deepened; and especially within the cities has the work of the municipal authorities expanded with stupendous increments far beyond even the startling development of cities and city population.

It is this recent and significant development of municipal activities which has made the question of municipal administration one of vital importance, and the study of it a subject worthy of the attention of students of political science.

The present work begins with a historical survey of cities and municipal government, treating briefly of ancient and mediæval cities and more at length of the development during the nineteenth century. From the time of the Greek city-state, when the city was the sum and centre of political 
life, the movement until the end of the eighteenth century is, on the whole, one of the growth of larger political units, which absorb many functions of the early city and subordinate the city to the state. But with the recent development of urban communities and municipal activities, the direction of the current has changed, and cities have again become important factors in the life of the times.

In the second part there is a general survey of the active functions of municipal administration. In this discussion two aspects of municipal activity need to be borne in mind. In the first place, the municipal authorities in many lines are acting as agents of the central government, performing what may be called state functions of local administration. In the second place, the municipality acts as a distinctly local corporation in serving the special local needs of the community. It is not possible to draw hard and fast lines in classifying the various functions into these groups. But in the main the municipality acts as agent of the state in reference to public health and safety, the work of charity and education; while the various undertakings described in the two chapters on municipal improvements belong for the most part to the domain of special local functions.

The third part deals with the problems of municipal finance; and different chapters consider questions of expenditure, debt, income, and finance administration. In the fourth part the various methods and problems of municipal organization are discussed, with special reference to recent tendencies and proposed reforms in American cities.

No attempt is made to deal with the local politics of any particular city; nor in the discussion of municipal functions can technical details of the various departments be given. The book aims rather to give a general knowledge of the whole field of municipal administration for those interested in public affairs, and at the same time to form the groundwork for more detailed investigation to those who make this a special field either for academic study or for practical work. 
It is necessary to make clear the relation of some parts of the book to other published writings. Part II is to some extent a development from certain chapters which I prepared for a monograph on Municipal Functions, published in Municipal Affairs for December, 1898; and considerable data then used have been incorporated into the present work. A few other portions have appeared in much their present form. Chapter V, on American Municipal Development, is revised from an article in "A Municipal Program"; the section of Chapter VIII on Police Administration appeared in the Political Science Quarterly for March, 1901; and Chapter XVI, on Finance Administration, contains large excerpts from a paper on that subject read at the meeting of the National Municipal League at Rochester, N.Y., in May, 1901, and published in the proceedings of that meeting.

The sources used in the preparation of the book are too numerous for mention here. They are indicated freely in the bibliographical references at the beginnings of the chapters and in the footnotes. Personal observation and investigation have also been made in a number of American and European cities; and for aid in these researches my sincere thanks are due to many kind friends and public officials.

Hartard Club, New Yore,

September 5, 1901. 


\title{
CONTENTS
}

\author{
PART I \\ MUNICIPAL HISTORY \\ CHAPTER I
}

The Cities of Antiquity . . . . . . . . 3

CHAPTER II

Mediaval Citiks $•$ •

CHAPTER III

European Cities, 15th-18th Centuries $\quad$ - $\quad$ - $\quad 32$

CHAPTER IV

The English Borodghs • • • • • • • 42

CHAPTER V

Municipal Development in the United States • • • 72

CHAPTER VI

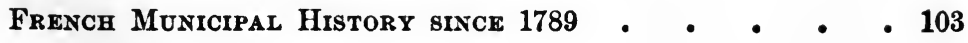

CHAPTER VII

German Cities in the Nineteenth Centurt • • • • 114 


\section{PART II}

\section{MUNICIPAL ACTIVITIES}

\section{CHAPTER VIII}

Pubuic Health and Safety.

Police Administration, Fire Brigades, Health Departments, Building Departments, Economic Regulation.

\section{CHAPTER IX}

Charities and Provident Institutions - • • • 182

Poor Relief, Pawnshops, Savings Banks.

CHAPTER X

Education

Schools, Libraries, Museums.

\section{CHAPTER XI}

Municipal Improvements. I

- 225

Streets, Bridges, Sewers, Scavenging, Baths, Parks.

\section{CHAPTER XII}

MUnicipal Improvements. II . • • • • • 270

Waterworks, Public Lighting, Urban Transportation, Docks, Markets, Cemeteries, Municipal Ownership.

\section{PART III}

MUNICIPAL FINANCES

CHAPTER XIII

Municipal Expenditures

\section{CHAPTER XIV}

Municipal Debts 
CHAPTER XV

Municipal Revenues

MUNTIPAL REVENUES

\title{
CHAPTER XVI
}

Finance Administration $•$ •

\author{
PART IV \\ MUNICIPAL ORGANIZATION \\ CHAPTER XVII
}

The Council • • • • • • • • • • • 375

CHAPTER XVIII

Administrative Officials . • • • • • • • 399

CHAPTER XIX

The Mayor • • • • • • • • • • 411 ?

\section{CHAPTER XX}

Proposed Plans of Municipal Organizatiox • • • 422 
intis. 


\section{PART I}

\section{MUNICIPAL HISTORY}





\title{
MUNICIPAL ADMINISTRATION
}

\section{PART I - MUNICIPAL HISTORY}

\author{
CHAPTER I \\ The Cities of Antiquity
}

Authoritles. - Maspero: The Dawn of Civilization. - Currios : History of Greece.-Grote : History of Greece. - SchömaNk: Antiquities of Greece. - Mans: Ancient and Mediæval Republics. - Mommsen: The History of Rome; Roman Provinces. - Fowlen: The City-State of the Greeks and Romans. - Lanciasi: Ancient Rome in the Light of Recent Discoveries. - Lanciavi : The Ruins and Excavations of Ancient Rome. - Gibron: Decline and Fall of the Roman Empire. - W. LiebzмАм : Städteverwaltung in römischen Kaiserreiche.

Although a striking characteristic of the nineteenth cen. tury, the phenomenon of great cities is by no means confined to this period, and such cities are to be found from the very beginning of recorded history. In the river valleys of the Nile and the Euphrates, where both fertile soil and easy transportation were at hand, the earliest civilizations developed the well-known cities of Thebes, Memphis, Babylon, and Nineveh, with other important places, whose names are perhaps not so familiar.

In her early history, Egypt was a self-sustaining and commercially isolated country; and there seem to have been no important cities other than the two political centres just named-Memphis and Thebes. But when in later times foreign commerce and intercourse developed through the influence of the Phœnicians and Greeks, new cities arose: Kopton on the trade route from the Sinaitic peninsula to Libya, with Cosseir on the Red Sea as its shipping port; 
Sais and Naucratis on the Delta of the Nile, in connection with the trade of the Mediterranean.

Almost nothing, however, is known of what we would call municipal conditions in these cities. The centre of interest in Egyptian history is the monuments, which were not in the cities and were not municipal works.

The great Oriental cities of Assyria and Babylonia were for the most part palace cities, where the royal residence was the centre of the whole. Maspero names fifteen cities of ancient Chaldea, in two groups, southern and northern. The most important of these were Lagash and Uru, near the mouth of the Euphrates, and Babylon farther north. To the east of Chaldea, Susa, the capital of the Elamites, is said to have vied with the richest cities of the Euphrates, Uru and Babylon, in antiquity and magnificence. As the lines of commerce from the Euphrates to the Mediterranean developed, Damascus began its important career, which has continued for so many centuries. Later, as the Phœnicians carried trade still farther west, their home ports of Tyre and Sidon grew to be considerable cities; while the trading posts established along the Black Sea, on the Mediterranean, and even on the coasts of Spain and Britain, laid the foundation for future cities such as Paphos in Cyprus, Rhodes, Gades (Tarshish, Cadiz), and Carthage.

Little more can be said of the municipal conditions in these cities than of the early Egyptian cities. It is known that in ancient Tyre the water supply was furnished by an aqueduct from the springs in the mountains, - probably one of the earliest instances of the kind. It may be assumed that in cities almost exclusively commercial in character, where political institutions were undeveloped, the range of public activity even for the local needs of the urban populations was extremely limited.

It was Greece that first showed the possibilities of the city in the political sphere. The city here was not merely a trading post, or the residence of the ruler of a large area, but the centre and sum of political life. The physical con- 
ditions of the country prevented for a long time the formation of large empires ; and each city was thus independent and self-ruled. Athens, Sparta, Corinth, Thebes, Calchis, Phœcea, each combined both the economic and political features of city life. Our word "politics," indeed, comes from the Greek word for city, and means literally the public affairs of the city.

But the Greek cities were not alone those in Greece proper. Probably influenced by the Phœnicians, the Greeks early took to maritime employments, and more certainly imitated them in founding trade cities. By the eighth century B.c. the founding of Greek cities on the coast of Asia Minor and the neighboring islands (Miletus, Ephesus) had gone so far that the Egean might be regarded as a Greek sea; and as the stream of emigration and commerce progressed further, still more new cities arose. Greeks founded the cities of Abydus, Cyzicus, and Synope, on the Dardanelles and Sea of Marmora; and thence along the coast of the Black Sea appeared Trapezus, Phasis, Tanais, and Obia, trade centres for the products of Armenia and the traffic from the great northern rivers, now in Russia. Other lines of trade led to Thrace; up the Adriatic to Corcyra ; to the Italian mainland at Cumæ, Rhegium on the Straits, and other points on the Gulf of Tarentum; to Sicily at Naxos and Syracuse; and finally to Marseilles (600 B.c.).

These Greek colonies were not, like the Phœnician ports, simply trading posts with temporary settlements; but, like the city-state in the home country, were permanent cities, political as well as economic centres. The cities of Sicily and Southern Italy became a Greater Greece (Magna Groecia) beyond the seas. And although all the Greek cities were related by trading lines, and still more by their common civilization and common religion, yet each was an independent community, with a vigorous political life and a large sphere of public activity.

Of the Greek cities, Athens is undoubtedly not only the most important, but also the most studied and the best known. We can therefore take that city as exemplifying 
the highest development of municipal conditions at this period.

Like all the other Greek cities, Athens was not a municipality, but a city-state, and there was no distinction in public activity between these functions which we would now call municipal and those which we would call state or national. For our purposes, however, the distinction needs to be remembered; and it is not necessary to consider here the Athenian system of judicial, military, and naval administration, or the regulation of economic activities. Of the functions now considered as properly municipal, police and sanitary regulation, if it existed at all, was extremely unimportant, but public works were undertaken to a large extent, and both charity and education were subjects of public action.

A public water supply existed at Athens from an early date, subterranean aqueducts having been built by the Pisistratidæ (527-510 B.c.). Roads from Athens to the surrounding country were also built by the Pisistratidæ with artistic monuments for milestones, bearing inscriptions in hexameter and pentameter. The port of Piræus was systematically laid out with two main streets and a large central square for business, the most celebrated example of the kind in ancient times; the work was done by Hippodamus of Miletus, who later laid out the cities of Thurii and Rhodes. The harbors and warehouses at the Piraeus were also owned by the government, and dues or tolls charged for their use by the merchants. There was also a large amount of public lands regularly cultivated, while the silver mines at Laurium formed one of the main resources of the government, until they were exhausted by the reckless system of mining employed.

Although so many of the sources of production were under public control, they were not operated by public officials, but were regularly let out on stated payments for longer or shorter periods to private capitalists who worked them for their own advantage, - early examples of the modern system of municipal franchises. There was indeed almost no public administration. Not only were the industrial enterprises of 
the government administered by private capitalists, but the taxes also were similarly farmed out, and the principle of personal service by private individuals was very largely used,in the choruses at the theatres, in the public games, in the judicial administration; and even in military affairs the furnishing of ships of war was a duty of wealthy citizens.

The system of public charities at Athens presents some peculiar features. The most important work of the kind was the distribution of imported grain to large parts of the population - a system often resorted to in other large cities in ancient times, and above all in Rome. Other aid was given by paying the poor for their services in the judicial administration, and furnishing them free seats at the great theatrical exhibitions.

Education was also under public control, especially that of young men in their duties as citizens; and closely connected with this was the physical training of the young men, with a view to military service. The higher education of culture and art was promoted in connection with the religious ceremonies in the theatres and temples; and the results in the development, especially of the drama and sculpture, mark a record of achievement which no other people have attained. It has been suggested, however, that the lavish expenditures for the famous buildings on and around the Acropolis were economically unsound, and helped to exhaust the material energies, and thus aided the decline of Athens.

A word as to Athenian finances. The principal sources of public revenue were:-

Revenues from public properties and industries; revenues from courts, which yielded a considerable net income; tribute from the allies; customs on imports and exports; octrois, duties collected at the city gates; taxes on resident aliens; and in emergencies, a direct property tax on all persons under the protection of the government.

The empire of Alexander differed from that of Persia, which it supplanted, in its development of commerce and city life. Alexander himself founded seventy so-called cities, 
thus recognizing the autonomous Greek city-community as the basis of his empire, in contrast to the former village life of the East. These cities differed in one respect from the Greek cities of the preceding period: they were not independent states, and, although with power of internal selfgovernment, were subordinate to the empire; they were municipalities rather than cities, although the Roman name had not yet appeared. The ancient cities of Greece itself were also placed in the same subordination to the larger empire.

No single city could now secure for itself the protection from external attack which was necessary to render economic progress possible. A more extensive form of political organization was necessary; and the city was superseded by the higher type of political life. But although no longer the organ for political and military administration, the economic importance and economic life was more fully organized, and given opportunities to develop with the powers of local government.

The new cities established by Alexander were deliberately planted; and many were systematically laid out by Democrates the architect. The same policy was followed by the successors of Alexander in the various districts into which his empire was divided. Under the Diadochi (cir. 300 B.c.) there were two hundred so-called cities in the Hellenized world; and although most of these were hardly worthy the name, there were many important places.

The two most famous cities of this period were Alexandria and Antioch. Alexandria was the centre of the grain trade from Egypt, and the emporium for products of India and Arabia coming by caravan and by sea from the Malabar coast of Hindostan to the harbors on the Red Sea constructed by the Ptolemies. The most important public works at Alexandria were the harbor and mole with its lighthouses, and the famous library. Antioch also was a commercial centre, for caravan trade from the East via the Euphrates. Rhodes, an old city, had risen to large importance, having succeeded to the naval supremacy which 
Athens had lost; and the harbor of Rhodes ranks among the greatest public works of the time. The Greek colonial cities in the Mediterranean continued to be centres of industry and depots of commerce; and, like the new cities were also centres of Greek learning, science, and art, which were extending Hellenic culture and civilization from Marseilles to Babylon.

Municipal development at this period consists entirely in the appearance of new cities. The public activities of the cities remained as they had been, - the construction of public buildings, harbors, quays, bridges, and aquaducts forming by far the most important functions. With all the activity in these directions, however, street paving seems to have been very exceptional, and street lighting as yet entirely unknown.

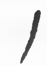

THE ROMAN PERIOD

The history of the expansion of Rome is the history of the conquest and foundation of a large number of cities; and in the Roman world there was an almost exclusive preponderance of cities and an absence of country populations and dwellings. The relation of these cities to the government at Rome at first varied widely. The neighboring Italian regions, which were first acquired, were treated rather as allies than as conquered districts. Each of the allied cities was under Roman rule in political and military affairs; but each was allowed to maintain its own customs, and so far as possible its own constitution. The local magistrates preserved even a considerable measure of judicial independence; and on the whole the communal autonomy involved much more real freedom than had been the case in Greece after the Persian struggle made the union of Greek cities necessary, for in Italy there was no tribute.

As the Roman power extended beyond Italy, the forms of conquest became more common. Nevertheless, the flourishing commercial cities, both Greek and Phœnician, thus included in the Roman dominion, preserved by treaty many rights and privileges. In some cases, as at Cadiz, 
Marseilles, Messina, and Athens (the civitates foderato), these treaties secured to the cities a formal independence and a real self-government. In other cases, cities classed as immunes - such as Utica, Smyrna, and Ephesus - were free from fiscal burdens. A larger number, but mostly less important places, did not enjoy self-government, but were under the rule of prefects, and were subject to the burdens, without enjoying the privileges, of Roman citizens. Tribute was naturally continued from those cities which had formerly been subject to Carthage or Macedon, and was also required from other cities in conquered territory outside of Italy. In still another class were the colonies, or new cities, founded to secure a conquered territory by transferring groups of veteran soldiers, to whom lands were allotted as a reward for their public services. These new municipalities from the first enjoyed much autonomy; but the maintenance of good government there was considered a matter of imperial concern. They were under occasional surveillance, and the frequent rescripts of the emperors on their affairs gradually assimilated divergent customs.

These distinctions between cities gradually disappeared. The policy of granting the Roman franchise to the inhabitants of other cities than Rome was inaugurated by Claudius, carried on by succeeding emperors, and finally culminated in the notable edict of Caracalla (211-217 A.D.) which conferred the civitas on all, both Latini and peregrini, under the sway of Rome. With this final step came the abolition of the exemption of citizens from taxation, and thus all cities were placed on a common basis. The Roman municipal town, thus evolved, has been defined in terms which answers almost perfectly to our present ideas, as "a community of which the citizens are members of the whole nation, subject to the same burdens, but retaining the administration of law and government in all local matters which concern not the nation at large." And it is interesting to note the close analogy between the legal concept of the Roman municipality and our own: in the required sanction of the State to its existence, in the power of the majority, in its fictitious personality, 
and the consequent responsibility before the courts for the obligations of its officers, and in its property rights. ${ }^{1}$

The appellation of city was no less vague in the time of Rome than it is to-day; and local pride and the poverty of language bestowed the same title upon the metropolis of Rome and many a petty village. Ancient Italy is said to have had 1200 cities, Gaul could boast of an equal number, Spain exhibited a list of 360 , Asia contained 500, and even Africa $300 .{ }^{2}$ But using the word in the stricter sense in which it has been defined.in these pages, the number and greatness of the cities in the Roman Empire are most significant. In the first century after Christ several cities of over 100,000 were in existence, while Rome has been estimated at from one to two millions, and Alexandria probably attained half a million. Even the latter figure was not reached again until the seventeenth century (by London and Paris), and the million mark not until the eighteenth century. In Italy, the splendor of ancient Verona may be traced in its remains; yet Verona was less celebrated than Aquileia or Padua, Milan or Ravenna. In Gaul, were Marseilles, Arles, Nismes, Narbonne, Toulouse, Bordeaux, Autun, Vienne, Lyons, Langres, and Treves, whose ancient condition was equal and perhaps superior, in Gibbon's opinion, to that at the time he wrote (1780). In Britain, York and London were seats of commerce, and Bath was celebrated for its medicinal waters. Carthage had risen in new splendor from its ashes. Capua, Corinth, and other cities in Greece were no mean places. In Asia were such important cities as Laodicea, Pergamus, Smyrna, and Ephesus. The capitals of Syria and Egypt (Antioch and Alexandria) held a still superior rank, looking down with disdain on a crowd of dependent "cities," and yielding with reluctance to the majesty of Rome itself.

As Athens was taken as the highest type of the Greek city, so imperial Rome stands preëminent among the cities of the Roman world, and a study of its municipal aspects affords lessons of interest and value. These show many features

1 Dillon, Law of Municipal Corporations, pp. 3, 4.

2 Gibbon, Decline and Fall of the Roman Empire, ch. 2. 
which correspond to those of the large cities of our present day, thus demonstrating that compact populous communities have special conditions and needs which demand special provisions for their health, safety, convenience, and good government. The water supply of ancient Rome formed a stupendous series of works. ${ }^{1}$ The first aqueduct was begun as early as 312 B.C., and the final system consisted of fourteen aqueducts, varying from $7 \frac{1}{2}$ to 59 miles in length, and aggregating 359 miles. Of this total 54 miles were above ground, the channel being carried on magnificent masonry arches, sometimes at a height of a hundred feet. This method of construction was used, not because the Romans did not understand the principle of the siphon, but because the soft metals then in use for pipes were not strong enough for the enormous hydrostatic pressure at the bottom of the valleys, if the conduits followed the surface of the earth. The water supply system not only included the aqueducts, but also large dams and storage reservoirs to collect the water in the hills. Drains and sewers were also constructed through the city, and the Cloaca Maxima, built twenty-five centuries ago through unstable marshy ground, is still in use, and ranks among the great triumphs of engineering skill.

From early days Rome had a body of watchmen, whose principal duty was in combating fires; but the system proved entirely inadequate to the conditions in the time of Augustus, and that emperor reformed the service and organized a force of seventy-five hundred guards, divided into seven battalions, each with its own headquarters. These acted both as a fire brigade and a police force; but the preservation of order and the protection of property continued to be poorly effected, one great difficulty being the absence of any system of lighting the streets at night. ${ }^{2}$ The police also regulated street traffic, and enforced the removal of waste and the repair and pavement of streets by the property owners. ${ }^{3}$ The early city had developed without public regulation of street lines or

1 Lanciani, Ancient Rome, pp. 52-62.

2 Ibid., p. 206.

Mommsen, History of Rome, V, p. 374. 
building construction; but after the burning of the city by Nero it was rebuilt on the plans made by the imperial architects, Severus and Celer, which provided wide streets and large squares where formerly had been filthy, densely built quarters. Under the new regulations the line of frontage of each new building had to be sanctioned by the authorities, and the height of private houses was limited to twice the width of the street. ${ }^{1}$

Public places of resort were frequent in Rome. At the end of the third century A.D. there were eight campi, or commons, - set aside mostly for foot races and gymnastic exercises, - eighteen fora, or public squares, with an aggregate area of twenty-five acres, and about thirty parks or gardens, which, first laid out by wealthy citizens for private grounds, had been absorbed by the government by purchase, by bequest, or by confiscation. The most famous of the public squares, known as the Forum, was in early days the market-place, and its western side was lined with butcher shops. By the end of the republic, however, this was completely changed, and the place had become an exchange for contractors and brokers - a prototype of Wall Street. The markets were then to be found elsewhere: the porticus Minucia served as a corn exchange, and the forum Olitorum as a market for fresh vegetables. ${ }^{2}$

Rome was also famous for its public baths. Evidently the water system did not reach most of the houses in Rome; and baths were built for general use, at first by private speculators. Agrippa left his thermce to the people, and the number of public balnea was largely increased by succeeding emperors. ${ }^{3}$ At the end of the third century A.D. there were eleven large public baths, besides over nine hundred smaller private establishments, with total accommodations for over sixty thousand persons at one time. ${ }^{4}$ These baths were much more than mere bathing-places; they were places of

1 Lanciani, Ancient Rome, pp. 122-123.

Ibid., pp. 74, 80, 94.

- Becker, Gallus, pp. 390 ff.

4 Lanciani, Ancient Rome, p. 89. 
resort and amusement, such as our modern clubs and theatres, and hence important factors in the social life of the city.

The great amphitheatres, circuses, and other places of public amusement were also built, and the spectacular shows in them furnished, by the government. The Circus Maximus alone could accommodate 285,000 spectators, all comfortably seated; the Circus Flaminius 150,000, and the Coliseum $87,000 .^{1}$

Another important work that may be classed as municipal was the harbor at Ostia. This was begun by Claudius, and perfected by Trajan, the latter's work including an enclosed inner harbor with 18 feet depth of water, with quays 2156 yards long, and warehouses aggregating 17,500 feet in length. There were also public warehouses in Rome for storing the grain imported by the government. ${ }^{2}$

This importation and the distribution of grain was the principal government work of poor relief. At first undertaken to meet special emergencies, in later times this public gratuity was a regular service, which reached enormous dimensions. Toward the end of the empire, public ovens were erected, and daily allowances of bread were given in place of the monthly distributions of grain. Special provisions were also made by the government for the importation of supplies of oil, wines, and other luxuries, which were given to the inhabitants of Rome on very easy and liberal terms. So far did this government aid go that the poorer citizens of Rome were almost exempted from labor. ${ }^{3}$

There do not seem to have been any government schools in Rome. There were, however, a number of large libraries. The first was built and opened 717 A.U.c., and by the time of Trajan there were six public libraries, besides many private libraries. The total number of volumes has been estimated at from 400,000 to $700,000.4$

In the early days Rome, like other Italian cities, had

1 Lanciani, op. cit., p. 216.

2 Ibid., pp. 238-240.

- Gibbon, Decline and Fall, chs. 17, 31.

- Lanciani, op. cit., p. 184. 
followed the Greek methods of public administration, developing, however, in the magnitude and complexity of the transactions. There was at first no tribute to be farmed, as at Athens; but the duty of collecting rents from the public domain was regularly put up at auction. Ships and military supplies were furnished by army and navy contractors. And the Appian Way, the aqueducts, and other public works were constructed by contract. The tenure of the city magistrates was so short that there was no other way in which such works could be satisfactorily organized and carried out than by letting them to private capitalists. ${ }^{1}$ But as the city developed, mismanagement and corruption became frequent. Under the empire, however, there was a radical change in the system of administration, which was not the least important of the changes in the governmental system at that time. Augustus organized an imperial administrative service which did away with the contractors, not only at Rome, but for all of the public works of the empire; and the greater part of the public works and buildings in Rome were constructed under this régime of direct public administration.

The other large cities closely followed Rome in the nature of their municipal activities. Amphitheatres, theatres, temples, porticos, arches, baths, aqueducts, drainage systems, all conducive to the health, devotion, and pleasure of the citizens, were to be found throughout the empire; and while these did not in every case represent municipal activity, they were all intended for public benefit. Even in Rome the greater number and most conspicuous buildings (as the Coliseum, the Baths of Titus, the Temples of Peace, the Forum of Trajan) seem to have been the work of the emperors in a personal rather than governmental way; and in various provincial cities many edifices were erected by private individuals. But there were also many instances of distinctly municipal action. The Coliseum at Rome was almost immediately duplicated on a smaller scale by edifices of the same design erected at the expense of the cities of Capua and

1 Cunningham, Western Civilization, ch. 2. 
Verona. The great bridge of Alcantara was thrown over the Tagus by a few Lusitanian communities. The aqueducts of Spoleto, Metz, and Segovia were works of no mean sort, surpassed only by the preëminence of those at Rome. ${ }^{1}$ At Antioch and Alexandria the water supply was distributed to the separate houses and shops, ${ }^{2}$ which appears to be more than was done in Rome. Antioch also had eighteen district baths, and is famous as the only city of antiquity of which we have positive information that the streets were lit at night, - although even in this case it is not known what were the means employed. A large number of cities had elaborate systems of sewers; Cologne, for example, in this respect and in its water supply had reached a point not regained until the nineteenth century. ${ }^{3}$ In most large cities there were regularly paved streets, but this work was probably done by the property owners, perhaps under pressure from the municipal authorities.

The outlay for public works of these sorts comprised the principal expenditure of the Roman municipalities. Other important items were the expenses of public amusements and of quartering soldiers. Probably some poor relief was given, as at Rome; but there was no organized system of charities, no municipal hospitals, and no public schools. The revenues of the municipalities were derived very largely from municipal property - lands, fisheries, mines, quarries, water rents, and other public works. There were also municipal tariffs, and receipts from fines, and fees collected from persons elected to office, while work was often executed by municipal slaves.

There was little popular influence in the government of these municipalities. There was a municipal senate or council, which directed the administration and also acted as local legislature. This council varied in number in different cities, but one hundred members was a usual number. The councillors were chosen for life, except that they might be

1 Gibbon, Decline and Fall, ch. 2.

2 Mommsen, Roman Provinces, II, 141, 185.

- Liebenam, Städteverwaltung in römischen Raiserreiche. 
removed at quinquennial revisions of the list. Former magistrates were ex officio members and formed a predominant part of the councils. ${ }^{1}$

From early in the second century the centralizing tendencies of the imperial government began to curtail the autonomy of some important municipalities, and step by step these tendencies developed until the central government gained complete control of the municipal towns. Extravagance, incompetence, and corruption in the municipal governments opened the way for this development. The earliest signs of it are found in the occasional appointment, by the emperor, in special circumstances, of a curator, or financial overseer, of a certain city to regulate expenditure, to prevent extravagance and misappropriation of funds, and to put the finances of the city on a sound basis. At first these officers were commonly Roman citizens and men of experience, who ranked far above the municipal magistrates; they were regularly selected from a different city, and did not take up residence in the city in which they acted. By the third century the curator had become an ordinary and regular official in many cities, selected from among those citizens who had already held office, sometimes directly by the emperor, but in other cases by the municipal senate, which was becoming more and more a mere instrument for executing the will of the central government. In the fourth century the curatores appear as the keepers of the lists and valuations of property of the different classes; and it is clear that they steadily encroach on the powers of the supreme board of magistrates, taking the entire management of the finances, property, and public works of the city, deciding questions between the state and any individual citizen, and becoming, with the municipal senate, the means by which the central government controlled and taxed the cities. ${ }^{2}$

The recognition of the Christian Church by Constantine led to further important changes in municipal government,

1 Liebenam, Städteverwaltung in römischen Kaiserreiche.

${ }^{2}$ Mommsen, Roman Provinces, I, 302; W. M. Ramsay, Cities and Bishoprics of Phrygia, II, pp. 369-370. 
which developed more fully after the downfall of the empire. Before the action of Constantine the Christian clergy had been only private persons; they now became important magistrates. In many places where the Christian religion was dominant, the civil municipality, finding the responsibility of government too great in the period of declining prosperity which had already begun, handed over to the Church the temples and even the law courts and basilicas; and the various public buildings were transferred and adapted to Christian uses. As time went on, in many cities the office of curator, which was compulsory, gratuitous, and costly to the holder, came to be filled usually by the bishop of the city. Thus the bishop of each city with his clergy took charge of all public affairs; the municipal senates had lost their authority, and the clergy took their place. ${ }^{1}$

1 Kitchin, History of France, I, 51-53. 


\section{CHAPTER II}

\section{Mediaval Cities}

Authorities.-Emerton: Mediæval Europe, ch. 15. - Haluam: Middle Ages, note to ch. 2, ch. 4. - MARTiv : Histoire de France, Bk. 19, passim. - Thierry : Lettres sur l'histoire de France, Nos. 13-24. - Thierry: Essai sur l'histoire des Tiers Etat. - GrRY : Documents sur les relations de la royauté avec les villes en France, 1180-1314. - FuACH : Les origines de l'ancienne France. - Luchaire: Manuel des institutions française. - Lucha IRE : Les communes française a l'époque des Capetiens directes. - HegeL : Geschichte der Städteverfassung von Italien. - HegeL : Städte und Gilden der germanischen Völker im Mittelalter.-MAUrer : Geschichte der Städteverfassung in Deutschland.-KAllsen: Die deutschen Städte im Mittelalter. - GierKe : Das deutsche Genossenschaftsrecht. - Sонм : Die Entstehung des deutschen Städtewesens. VoN Bü Low : Der Ursprung der deutschen Städteverfassung. - Ashrer : In Quarterly Journal of Economics, X, 359.-De CALonse: La vie municipale au XVe siècle.

THE Germanic invasions which led to the downfall of the Western Roman Empire mark also a serious retrogression in city life throughout Western and Southern Europe. In Northern Gaul, Rhætia, and Noricum there were large areas where Roman traditions retained but a feeble influence; and the cities of Great Britain ceased to exist as centres of social life. Many of these towns were dependent for their prosperity on commerce ; they had been depots where goods were collected for exchange, or whence corn was shipped to Rome ; and the interruption of their commerce was fatal to their existence. Others, which had been centres of manufactures, no longer found opportunities for procuring materials or disposing of their products. The economic basis of city life was destroyed, or even at best served only to maintain a greatly diminished population. The administration of municipal affairs in the cities fell most generally to the control of the Church. The movement which had begun in the time 
of Constantine now became general. The civil municipal officers sank into insignificance, while the bishops and clergy succeeded to their powers. The codes of Theodosius and Justinian contain innumerable edicts placing the management of municipal affairs in the hands of the clergy; and the ecclesiastical municipal system thus developed was the prevailing type during the early Middle Ages. ${ }^{1}$

In Southern Gaul, Spain, and Italy some of the old municipalities survived the storm and maintained the traditions of the Roman period. But they were few and far between, and their municipal life was on a much more contracted scale than heretofore.

These movements did not, however, directly affect the cities of the East. Constantinople, Damascus, and Alexandria remained important places. After the rise of the Mahometan and Arab power, new cities of importance appeared, in connection with the development of trade. The capitals, Bagdad and Cairo, were the largest and most famous; Bassorah on the Persian Gulf, Trebizond on the Black Sea, and Samarcand on the route to China were all considerable towns. And in Spain, whither the Arab power extended, the cities of Toledo, Cordova, and Granada arose into prominence. Cordova, the capital of the Spanish caliphate, was said to have in the tenth century 200,000 houses, 600 mosques, 80 schools, and 300 baths. $^{2}$

\section{ITALIAN CITIES}

Beginning in the eleventh century, we find a revival of city life throughout Southern and Central Europe, and though on a much smaller scale than the great cities of the Roman Empire, this movement played an important part in the larger political history of the time. This revival of city life was due in considerable degree to the commercial development resulting from the contact of the East and West in the Cru-. sades. The Italian towns furnished ships to the Crusades, established commercial ports in the new Latin principalities

1 Guizot, Civilization in Europe, pp. 52-53.

2 Gibbon, Decline and Fall, ch. 51. 
in Syria, by degrees supplanted the Greek traders in Constantinople, and developed trade with China via the Black Sea, the Russian rivers, and Samarcand, and also with the East India spice islands through Alexandria. The ascendancy among the Italian towns in this trade was first held by Pisa ; but toward the end of the thirteenth century this was wrested by Genoa, although Pisa continued an important city until 1406, when the place was purchased by Florence, and the policy of the latter was to promote the development of Leghorn as its port. Meanwhile Venice was contesting with Genoa for the position of supremacy, which it finally gained. The Venetian trade was not only with the East, but also by land to the German cities, and westward by water to Lisbon, to England, and to the low countries.

Related to these South European currents of trade were several important ports in France-Marseilles, Montpellier, Aigues-Mortes, and Barcelona in Catalonia (Spain). These commercial cities were also centres of industry, - the southern French towns for the manufacture of woollen goods, Italian cities for silk manufacture, which also promoted the development of cities off the coast, such as Lucca and Florence. Other Italian cities of importance were Bologna, Padua, Brescia, Modena, and Sienna.

Along with the development of population in these centres came the revival of cities as local communities, which gradually won a position outside of the feudal system of the time, and in many places revived practically the city-state of earlier history. The earliest mediæval artisans were, like the agricultural laborers, serfs, but one stage above the true slave. Step by step, these artisans organized themselves into gilds which dealt with the feudal lord as a body; and by combining these artisan gilds with associations of merchants, gradually local communal organizations were perfected, independent of the feudal power.

The type of government first evolved throughout Northern Italy was that known as the consular, first instituted at Milan about 1093, and at Genoa in 1100 A.D. The executive 
officers were known as consuls - generally twelve in each city; by the side of these were officials known as judices or sapientes, forming a council, and below these stood the parlamentum, or general assembly of all full citizens. The basis for this organization was the merchant and artisan gilds.

During the contest between the Italian cities and the emperors, whenever the latter gained possession of a city he appointed a single governor known as the podesta; and from this time the other cities seemed to find an advantage in the single executive, and in place of consuls elected a podesta, who was regularly a stranger, chosen for a short time (one year or six months). In these latter cases, however, the podesta was limited by two councils, and the parlamentum was retained for cases of special importance.

The typical city for this process of development is Milan, but with minor local differences it holds good also for the other cities of Lombardy, Tuscany, and Romagna. In Florence and the cities of Central Italy the gilds assumed a more outspoken political character, and gained exclusive control over the government. In Venice, however, - an old Roman community largely exempt from Germanic influences, - the aristocratic element always maintained the upper hand, and the "Closing of the Grand Council" in 1297 definitely fixed the select list of families into whose hands alone the government of the republic was to rest. In the other Italian cities, after the thirteenth century, there was a gradual rise to power within the democracies of a new aristocracy based upon certain well-marked families. From the fifteenth century some one of the great families in each community forced its way to leadership, and these finally became the petty monarchs of the sixteenth and seventeenth centuries.

It would be easy to go into further detail in the study of the organization of government in these cities, and to note their part in the political history of the time, especially as the internal undertakings of the cities were of much less importance than has been already noted in ancient cities. These mediæval Italian cities never attained the dimensions 
of the largest cities, - Florence, for example, at the height of its power did not have over 150,000 population. But we are here concerned only with their municipal affairs.

The principal local public work in the early period was the construction of walls, ramparts, and fortifications for defensive purposes in the military struggles; and these walls, by making it possible for the city to hold its own against attack, aided in the future development of the city. And as the cities grew beyond the old walls, new walls had to be constructed. Thus the first walls of Milan were built in 900 , and extended walls were made in $\mathbf{1 1 8 3 .}$

During the twelfth century Pisa built her cathedral; Milan undertook irrigation works which permanently enriched the soil of Lombardy; and in other cities ports for the development of water commerce, and roads, were provided. By the fourteenth century the growth of the cities in population, extent, and wealth brought about the amplification of streets and public places. In Venice the canals were deepened and wooden bridges replaced with stone structures. The first stone bridge there was built in 1360; the famous Rialto was not built in stone until 1591. The Milan town hall, built in 1415, was one of the earliest public buildings of note; and it was followed during the next hundred years by many public buildings in other cities.

Outside of public works, municipal functions developed only to a very limited degree. There were small bodies of night watchmen, while the military forces of the cities could also be used for purposes of internal police. Regulations to prevent fires were established, but evidently no organized fire brigades. There were some municipal institutions for the relief of the poor, but ecclesiastical charities continued to be the most important. The following items from the budget of Florence for the year 1366 will illustrate the status of municipal finance in these Italian cities: ${ }^{1}$ -

1 Larouse, Encyclopédie Universelle, Article "Commune." 


\section{REceIPTS}

Octrois on merchandise .

Octrois on wines . . . . . . . . 59,300 "

Taxes on country districts . . . . . . . 30,100 "

Salt tax .

Confiscated property of rebels and exiles

14,450 “

7,000 “

3,000 " "

Tax on money-lenders.

Tax on contracts

Tax on slaughter-houses

Tax on loyers .

Tax on grain and mills.

Tax on citizens chosen as podestas in other cities

11,000 “

19,400 - “

4,050 “

4,250 “

3,500 “

Tax on houses

Total

\section{EXPENDitures}

Salary of podesta and household .

15,240 livres.

Salary of captain of the guard

Salary of sheriff (executeur de justice)

Salary of mounted guard

Salary of six hundred night watchmen .

Ambassadors .

Military guard in fortresses

Total ordinary expenditures

$\frac{5,500}{300,000}$ “

The total of ordinary expenditures equals 39,119 florins. The balance of the revenues were expended for extraordinary purposes, in which are included expenditures for walls, bridges, churches, and other public works.

\section{SPAIN AND FRANCE}

In Spain, the municipal movement began even before that in Italy, and developed along independent lines. As early as 1020, the city of Leon received a charter of incorporation; and this was soon followed by charters to other important urban communities in Castile, Leon, and Aragon. These charters generally granted to the citizens the right of electing their own magistrates and a council for the regulation of municipal affairs. A large extent of territory was included in the jurisdiction of each city, embracing other towns and villages; and private estates were also granted 
to the municipalities for the support of the magistrates and other public expenses. There was, however, in every city a governor appointed by the king, who received the usual tribute, and controlled the police and fortified places. This municipal system prevailed for over two hundred years; but during the fourteenth century the government of the Spanish cities was brought under the direct control of the crown.

The cities in what is now Southern France followed the same general development as those in Italy, except that the podesta does not appear so frequently. Early in the twelfth century the consular system is found in the Provence cities of Arles, Marseilles, and Avignon; and from there spread west and north to Béziers, Montpellier, Toulouse, Narbonne, and other cities. But none of these cities attained to the material prosperity and development of the Italian cities; and all were destined to succumb eventually to the centralizing influences of the French monarchy.

In Northern France economic conditions did not lead to the development of such important cities as in Southern Europe. But the inroads of the Northmen in the ninth century had driven men to seek the shelter of town walls, and during the eleventh and twelfth centuries there is a marked increase in the material prosperity of the towns, and at the same time a great movement for self-government, known in history as the rise of the communes. In some towns, such as St. Quentin, Cambrai, and Laon, a governing nucleus existed in the maire and echevins, officials dating from the Carolingian times; in others, the trade associations or gilds of merchants formed the basis for communal organization; while at still other places, such as Poitiers, Mantes, and Châteauneuf, the commune grew out of a religious society. But in all cases the result was the same : smaller unions within the town led to the emancipation of the town itself from the feudal overlord. ${ }^{1}$

Most often, however, the independence was only partial. In the villes affranchis, for instance, the seignorial lord retained the right to try, fine, and hang the inhabitants, but

1 Kitchin, History of France, I, 281. 
received a fixed sum in lieu of the feudal dues and corvée formerly levied on the individuals in the community. Most of the towns in Normandy, Maine, and Poitou were governed by the Établissements du Rouen, a constitution granted by Henry II of England, which left the choice of the maire to the crown. A large number of places had the charter of Baumont, which granted only a semi-independence, as did also the Vexin charters. In other places there was a regularly elected magistracy for administrative work, but no judicial system except that of the seigneur. The fullfledged commune, however, had still larger autonomy, and had judicial as well as financial and administrative independence. The most important cases of this sort were Beauvais, Lille, Dijon, Noyon, Laon, Rheims, and Lyons. But in every case there was a superior to whom certain duties were owed, and none of the French communes reached the political independence of the Italian and German free cities.

The communal movement was favored by the antagonisms between the nobles and the clergy, the former being more needy and less jealous of their rights, and so the more willing to sell a charter of privileges. The kings of France were in part friendly, in part hostile. They were glad to see communal charters granted where they would lessen the power of some great noble or cleric, but took care not to grant any in their own domain lands. Thus in Paris the first street paving (1180) and the wall around the city (1190) were constructed under direct orders from the king, Philip Augustus. During the thirteenth century the Paris water merchants' gild was granted important powers, and until the middle of the fourteenth century the provost of the merchants had under his control the administration of the principal municipal affairs, - the fortifications, gates, night watch, streets, wharves, bridges, and water supply; but after the death of Étienne Marcel (1358), a large share of these matters was transferred to the royal provost of Paris.

During the thirteenth and fourteenth centuries, too, many of the communes became subject to the crown. The gov- 
ernment of many places had fallen into the hands of oligarchies, which oppressed the lower classes and squandered the municipal finances, while not a few communes were distracted by riots and bloodshed. The growth of the royal power during this period made the king the immediate overlord of many communes; and under the disturbed conditions royal interference was often invited, and often imposed without invitation. Charters were surrendered to the king, constitutions reformed from Paris, and municipal debts extinguished by taxes levied by royal officers. ${ }^{1}$

\section{THE GERMAN FREE CITIES}

Before the tenth century there were very few large cities in Germany, and the small urban centres - whether dating from Roman times, or of later origin - were within the immediate jurisdiction of some bishop or duke. But, contemporaneously with the movements just noted in Italy, France, and Spain, the German cities gained their independence from feudal authority, and at the same time began their rapid development in material prosperity. This material development was in part due to the same commercial movement following the Crusades which resulted in the rise of the Italian cities; but there was also a local industrial development which promoted the growth of some cities, while others were the outcome in large measure of a commerce entirely distinct from the Mediterranean Levant trade,- namely, the trade with the Baltic countries in grain, timber, and naval stores.

The South German cities were ranged in three tiers. Farthest to the south were the Alpine towns: Berne, Basel, Zurich, Constance, Innsbrück, where besides the carrying trade there was a thriving linen manufacture, and Salzburg, the great source of salt. A middle tier of towns lay along the Danube : Regensburg, Ulm, Augsburg, and Vienna were the most important. The greatest of these in the later Middle Ages was Augsburg, which was the centre of the linen

1 Kitchin, History of France, I, 358. 
and woollen industry, and also the home of large banking firms. Farther north, the principal places were Nuremberg and Frankfort-on-the-Main. Nuremberg was a strong rival to Augsburg for preëminence, its prosperity being due mainly to the artistic metal industries, such as engraving, die-cutting, and carving. Frankfort was the seat of a great fair, which brought together traders from all parts of Germany. In the north there were also three groups of German cities: along the Rhine, in Saxony, and on the shores of the Baltic. The principal Rhenish towns were Strasburg, Mainz, Cologne, Dordrecht, and, most important of all, Bruges, which had a population of 180,000 ; the leading Saxon towns were Magdeburg, Leipzig, and Breslau; and along the Baltic the most important cities were Lubeck, Danzig, Bergen, Novgorod, and Wisbay. In the fourteenth century Lubeck had a population of 80,000 , or double that in 1870 , and larger than it has at the present time.

These German cities were much more successful than the French communes in securing and retaining their emancipation from feudal lords and their self-government, - that is, government through their trade organizations. During the eleventh and twelfth centuries the struggle between the cities on the one hand and the bishops and dukes on the other hand was at its height, ending in the success of the - cities. The cities within the empire then remained subject only to the vague and meaningless supremacy of the emperor, while those outside of the empire were also practically independent. All of the important cities were, however, united by alliances and treaties with other cities. The most important of these unions was the Hanseatic League, embracing the cities of North Germany and the Baltic region. This was a commercial federation with a central council, armed forces, and a common treasury to which each city was required to contribute. To this extent the German cities did not have complete independence. But in their internal affairs each city was autonomous; the scope of their jurisdiction included judicial administration and the regulation of commerce, so that the "free city" lacked but little of the sovereign 
authority possessed by the city-states of Italy and the ancient world.

Of their internal - what we should now call their municipal - affairs, one of the earliest and most important was the management of public markets and fairs. Regensburg had a market as early as 926 , and Cologne had a provision market by the latter part of the same century. The privilege of holding the Leipzig fairs has belonged to the town council since the twelfth century, and many German cities can trace their public markets back to the thirteenth century. Often the city owned open agricultural fields in the surrounding country, which were allotted to the peasants as in the rural towns.

The development of the cities is shown by the construction in many places during the thirteenth and fourteenth centuries of large town halls, many of which are still in existence. In some cases there were also public storehouses belonging to the municipality. One almost universal institution was the public baths. Baths in private houses were as yet almost unknown; but these public institutions, although primitive and crude compared with the magnificent establishments in the time of imperial Rome, were significant instances of municipal activity.

At the end of the thirteenth century Lubeck had a bathhouse on almost every street; in Ulm at the close of the Middle Ages there were eleven public bath-houses, in Nuremberg twelve, in Frankfort at least fifteen, and in Vienna thirty. A school ordinance of Nabbing decreed that the school children be taken to the baths in the middle of the week, because on Saturdays they were monopolized by the adults. ${ }^{1}$

Water supply was probably under public control, but there is no evidence of any extensive works being constructed at this period. In most cities the only street paving and cleaning was that secured by ordinances requiring property owners to pave and clean the streets before their premises; but at Bruges and Ghent, in the thirteenth century, there are mu- 
nicipal accounts for paving the principal streets. Usually the streets were badly paved, full of holes, poorly cleaned, and in the business sections covered with merchandise. Even the alignment of streets was for a long time not subject to control, and the width varied according to the pleasure of the property owners in constructing their buildings. Ordinances regulating the construction of buildings date from the fourteenth century. Fires were frequent and disastrous, sometimes destroying entire cities; yet the only attempt to organize a fire brigade was by ordinances naming certain persons to act as firemen. Thus, in Cologne, thirteen carpenters, thirteen smiths, and thirteen roof coverers were named to act in this capacity. Watch duty was required of citizens, and there was no regular police force until the fifteenth century, when organized police were first established at Basel (1421) and Vienna. Augsburg and Vienna, and probably other cities, had municipal postal services as early as the fourteenth century. ${ }^{1}$

The principal field of municipal legislation was the regulation of trade and industry, each city enacting rules as to prices, quality, weights and measures, importation and exportation. It was an age of municipal tariffs, and municipal control of all economic activity. Police regulation was also minute and extensive, and even attempted to control personal expenditure. ${ }^{2}$

During the early Middle Ages the care of the poor, the infirm, the sick, and dependent children was entirely under Church control. But during the thirteenth and fourteenth

${ }^{1}$ Maurer, II, passim.

${ }^{2}$ For example, in 1485, the Council of Regensburg, wishing to lessen growing extravagance, made the following rules with regard to dress: "The distinguished wives and daughters of burghers shall be allowed eight dresses, six long cloaks, three dancing dresses, and one plaited mantle having three sets of sleeves of velvet, brocade, or silk, two pearl hair bands not costing more than twelve florins, a tiara of gold and pearls worth five florins, not more than three veils costing eight florins each, a clasp not having more than one ounce of gold, silk fringe to their dresses, but not gold or pearl, a pearl necklace not costing more than five florins, a pearl stomacher worth twelve florins, two rows of pearls around the sleeves at five florins per ounce, a gold chain and pendant worth fifteen florins, and a necklace worth twenty florins." 
centuries many hospitals were constructed, or their administration assumed by the municipal authorities, and city physicians were appointed. The Church also had a monopoly of education under the mediæval system. Municipal Latin schools were, however, founded as early as the thirteenth century ; and the first common schools were established by some German cities in the fourteenth century. But, while the funds and the initiative for these municipal schools came from the city authorities, the teaching and management remained ir the hands of the clergy.

The central organ of government in the German cities was the town council; and while its constitution varied somewhat with the size and wealth of the cities, there were certain main resemblances. There was usually a large council for deliberation, and a smaller council of from twelve to twenty-four members which directed the details of administration. Both councils were composed of members from the various trade and artisan gilds in the city, merchants ordinarily filling the chief places. There were also two or four burgomasters in each city, who presided over the council meetings, but had no special privileges or influence in the government. ${ }^{1}$ There was a broad popular basis to the government; and while the administration may be called aristocratic, it was a local aristocracy whose interests were dependent on the prosperity of their cities.

${ }^{1}$ Zimmern, The Hanse Cities. 


\section{CHAPTER III}

\section{European Cities from the Fifteenth to the Eighteenth Centuries}

Authorities. - Mothey : Rise of the Dutch Republic ; History of the United Netherlands. - BLoK : History of the People of the Netherlands. Martin : Histoire de France.-Block : Administration de la ville de Paris. - Ashley : Economic History.

Following the age of the mediæval cities, there is a long period when cities and city life are of much less comparative importance. Several causes served to bring about this change in the situation. The development of strong national governments in France, Spain, and England deprived the cities of much political power they had possessed during the Middle Ages. Even in Germany the principalities, step by step, gained in importance, and the cities were placed in a subordinate position. Of especial importance to the material welfare of the cities was the change in the control of economic affairs from the cities to the larger governmental authorities; and with this came the abolition of privileges and regulations which had helped to build up the cities at the expense of the country districts. Perhaps these changes served to promote an important development in economic methods at this time which also retarded city growth. This was the transition from the "gild system" of manufacturing to the "domestic system." Under the former, manufacturing industries had been mainly confined to the cities; under the new system, they were carried on very largely in country districts. Another factor was the almost constant state of war throughout Europe, which interrupted land commerce, and led to the destruction of important cities.

While these causes combined to produce a marked decline in the importance of cities dependent on manufactures and 
inland commerce, other forces produced significant changes in the cities dependent on sea-borne commerce. The principal factors in this development were the discovery of America and the new sea route to the East Indies. These events vastly increased the carrying trade of the world, and, at the same time, completely recast the trade routes and the commercial centres of the world. Thus, the commercial cities of Italy, already affected by the action of the Turks in closing the old trade routes to the East, were not situated so as to gain the advantage of the new routes, and their prosperity declined. The cities of South Germany, which had prospered by the trade via Italy, also suffered by these trade changes. New centres arose for the new routes to the East Indies and the new trade to America, mainly in the countries which had taken the lead in the explorations and in opening the new routes.

For the Spanish trade, the old Roman city of Seville was given the monopoly as a port of entry and exit. This was sufficient to give it a commanding position among the commercial cities, and this position it retained until the silting up of the Guadalquivir River, in the latter part of the sixteenth century. Cadiz then became the Spanish port, and the leading city of Spain, holding the monopoly of trade from 1720 until 1765. For a considerable period, however, the acquisitions of Portugal were of even greater economic value than those of Spain; and the Portuguese trade, centring at Lisbon, made that place the most important commercial city of the time, and it remained one of the great cities of the world down to the eighteenth century.

Toward the end of the sixteenth century, the cities in the Netherlands came to the front. These had gained their political freedom in the same period that marks the rise of the Free Cities in Germany, and, in most cases, their charters date from the twelfth century. ${ }^{1}$ At the time when the Hanseatic League was most flourishing, Bruges and Ghent were the principal cities in the low countries; but

1 Dates of charters : Ypres, 1174 ; Orchies, 1175 ; Ghent, 1176 ; Oudenarde, 1177 ; Bruges, 1180. 
while most of the Hanse cities were now going backward, the Dutch and Flemish cities were becoming more important. It has been estimated that as early as 1500 one-half of the population in the province of Holland lived in towns. One of the early factors in this development was the appearance in the North Sea of the herring shoals, which formerly visited the Baltic, thus opening up a new industry to the people of the low countries. And with their experience in the sea fisheries, the Dutch were later able to take the active part in exploration, in founding colonies, and in the carrying trade, which secured their prosperity during the seventeenth century.

The Dutch cities, like those of Germany and Italy, controlled extensive districts and many villages; and their autonomy was so complete that they were not simply municipalities, but petty states. During the sixteenth century the schouts appointed by the feudal courts exercised some control over the composition of the municipal governments. ${ }^{1}$ But the government of the United Netherlands, formed in the struggle with Spain and retained after independence was won, was controlled by the cities. In several provinces the States-General was mainly or wholly composed of representatives from the cities. In the internal government of the cities there was still much use made of the gilds; but the artisan gilds, as well as the merchants' associations, shared in the authority, and the mass of privileges was so large and the shareholders so numerous that practically the cities were republics. ${ }^{2}$

Special mention may be made of the most important cities. During a large part of the sixteenth century the leading city in the low countries was Antwerp. This had gained much of the trade of Bruges, when, toward the end of the fifteenth century, the river to that city became too shallow for seagoing vessels; and in the sixteenth century, through the influence of the Spanish government, Antwerp also became the Northern centre for trade with the East Indies and

1 Blok, History of the People of the Netherlands, II, 350.

Motley, Rise of the Dutch Republic, I, 81. 
America. Twenty-five hundred vessels were often to be seen at one time within the harbor; and the arrival and departure of 500 vessels in a single day are recorded. The population rose to 200,000 , a figure surpassed by no city in Europe at the time, except Paris. But with the rise of the Dutch Republic, Antwerp declined. There was constant strife with the Dutch; and in 1648, by the Treaty of Westphalia, the river Scheldt was closed to navigation and Antwerp shut off from the sea. In twenty-five years its population fell one-half.

Next to Antwerp at this period, but in earlier times far surpassing that city, was Ghent. At the end of the thirteenth century it was larger than Paris; in the fourteenth century, Froissart estimated its military strength at 80,000 men; at the beginning of the fifteenth century the woollen manufactures there employed 40,000 men: and even in the middle of the sixteenth century its population was but little behind that of Antwerp. ${ }^{1}$ Another important Flemish city was Brussels, a city since the twelfth century, which in $\mathbf{1 5 5 5}$ had a population of $100,000 .{ }^{2}$ Bruges still remained a city of note; while Ypres, Louvain, and Bois-le-duc also deserve mention.

In the Dutch Republic the most important cities were Rotterdam and Amsterdam. The former had succeeded to the trade of Dordrecht, since an inundation of 1421 had shut off that place from the mainland. Amsterdam, which had been only a village in the twelfth century, came to the front with the success of the Dutch ; and it soon supplanted Antwerp as the commercial entrepot of the world. During the twenty years of the great war (1590-1609), its population increased from 70,000 to 100,000 ; and this latter figure was more than doubled in the following decade. ${ }^{3}$ By the middle of the seventeenth century, London had become the principal commercial city in Europe, but Amsterdam remained an important city until the middle of the eighteenth century.

Toward the end of the sixteenth century there was a re-

1 Motley, Rise of the Dutch Republic, I, 60.

2 Ibid., I, 96.

3 Motley, History of the United Netherlands, IV, 557. 
vival in German city life. Hamburg, one of the few cities which retained their mediæval independence, by securing some of the Antwerp trade, regained in part its former power. Farther east, Danzig came to be the principal centre of the grain and timber trade, which formerly came via Novgorod; while Riga grew to importance as a shipping point for flax and hemp used in linen manufacture, which developed in Western Germany. Westphalia was the principal seat of this industry, and to it was due the rise, during the seventeenth century, of Elberfeld and Barmen. Some of the older cities in South Germany, such as Augsburg and Nuremberg, still remained of considerable importance.

Municipal conditions in these Netherlands and German cities, in the sixteenth century, showed a perceptible advance over those of the fourteenth century. In most cities the streets were now passable. Pigs and cows no longer browsed freely in the public ways, and paving was more common; although the paving stones were still bad and the cleanliness of the streets was not above reproach. ${ }^{1}$ Even in the less important towns there was a public square for market traffic, while in the larger cities the principal streets and squares were of spacious dimensions. In many places substantial city halls, or Stadthäuser, were built; while the elegant public buildings in such cities as Antwerp, Ghent, and Brussels are still among the famous examples of architecture. Perhaps the most noted is the city hall of Brussels, "with its audacious and exquisitely embroidered tower, 366 feet in height, a miracle of needlework in stone, rivalling in its intricate carving the cobweb tracery of that lace which for centuries has been synonymous with the city, and rearing itself above a façade of profusely decorated and embroidered architecture." 2 At Ghent was the well-known belfry, "where for centuries had perched the dragon sent by the Emperor Baldwin of Flanders from Constantinople, and where swung the famous Roland, whose iron tongue had called the citizens generation after generation to arms." 3

1 Blok, History of the People of the Netherlands, II, 352.

${ }^{2}$ Motley, Rise of the Dutch Republic, I, 96.

Ibid., I, 60. 
Other important public works were the city walls. The walls of Ghent were nine miles in circuit, those of Brussels six miles, - the latter dating from the fourteenth century. In the seaport towns the harbors and docks were extensive works, those at Antwerp deserving special mention. At least one city had something analogous to the modern public park. Within a quarter of a mile from the city walls of Brussels was the forest of Soignes, which was used as a recreation and hunting ground. Some special equipment for suppressing fires was provided, especially in those cities where the ravages of the flames had been felt; and, in the seventeenth century, hand-pumping engines and leathern hose were invented and brought into use.

Important advances were also made in the fields of education and public charity. Already in the fifteenth century municipal efforts toward poor relief are evident in the purchase, in times of scarcity, of supplies of grain by German cities. ${ }^{1}$ But of more importance is the reform in charity work early in the sixteenth century. This was begun at Ypres in 1525, where a system of municipal control over private and ecclesiastical charities was introduced, a reform in hospital methods inaugurated, an organized attempt made to find work for those in need, and begging forbidden. ${ }^{2}$ The main features of this system of organized charity effort were adopted in some other cities; while after the break-up of the ecclesiastical system in the Reformation movement many new charitable institutions distinctively municipal in character appear. Unfortunately these efforts were not permanently successful, and the system of organized charity broke down, probably owing to the tremendous strain of the conditions produced by the Thirty Years' War.

The ecclesiastical changes also developed an opportunity and a pressing need for a new educational system ; and municipal institutions, both new and old, assume a more prominent position. In the larger cities the municipal schools became centres of culture, and in some cases even miniature universities. ${ }^{3}$

1 Ashley, Economic History, II, 11.

2 Ibid., II, 350.

3 Blok, History of the People of the Netherlands, II, 352. 
In France the economic measures and public works of Colbert, toward the end of the seventeenth century, promoted an increase in commerce and industry, and caused the development of some cities, notably Paris, Toulouse, and Lyons. The last named was the centre of silk manufacture, which had been first promoted by Francis I and Henry IV. Under the new stimulus in the seventeenth century this industry at Lyons employed from nine to ten thousand looms, but the revocation of the Edict of Nantes and the expulsion of the Huguenots struck a serious blow at industrial and city life in France. In Lyons the number of silk looms in operation was reduced to one-third of those formerly employed, and in other cities also population and industries were seriously affected.

One French city, however, continued to prosper. That was Paris, which, as the seat of government, gained with the growing centralization of power. Social factors also promoted its growth, while some of the principal industries fostered by the economic legislation of Colbert were located here. Throughout the period now in review, Paris was the largest and most important city, not only in France, but in all Europe. It is there we shall find the greatest advance in municipal conditions, although, as must be remembered, the improvements were introduced by the royal government, and there was no important local self-government in Paris.

The population of the city as early as the beginning of the fourteenth century was said to be 300,$000 ;{ }^{1}$ but it suffered severely from the ravages of the Black Death in 1356, and probably was below rather than above that figure at the beginning of the fifteenth century. But after that time it steadily increased, until in $\mathbf{1 7 2 0}$ the number of its inhabitants reached $1,400,000 .^{2}$ The progress of the city is especially marked after the advent of the Bourbon monarchy at the close of the sixteenth century. Henry IV constructed the Pont Neuf from the north to the south bank of the Seine, across the island of la cité, and the rapid growth which followed on the southern side of the river necessitated an extension of the

1 Martin, Histoire de France, VI, 44.

2 Ibid., XV, 53. 
ramparts around the city. In the time of Louis XIII the island of St. Louis, just above la cité, became a populous parish, with streets laid out in straight lines. But even at this time little had been done to improve the older part of the city. The streets were narrow and poorly paved; regulations dating from the middle of the sixteenth century requiring householders to place lanterns at the street corners were not enforced, while the police control was so ineffective that bands of robbers were active and made both life and property unsafe. ${ }^{1}$

It was not until the reign of Louis XIV that important steps were taken in the improvement of municipal conditions, which mark the beginnings of modern city life. The city had spread beyond the old fortifications of Marcel, and these were now levelled and boulevards constructed along their sites, while other boulevards were laid out in the new districts to the north. Something was done in the enlargement of old streets; additional water supply was secured; new quays were built along the water front; while the completion of the Louvre, the Tuileries, the gardens of the Tuileries, the Champs-Élysées, and the construction of arcs de triomphe at various points added to the artistic and architectural features of the city. ${ }^{2}$

In 1667 the office of lieutenant of police was established in place of the former royal provost of Paris. This office developed into an important detective agency of the government, for political purposes, but it was also charged with the maintenance of public security and health in the metropolis. The patrol of the streets was performed by a small guard employed by the city; but the forty-eight commissaries, or police justices, were under the control of the royal lieutenant. La Reynie, the first lieutenant of police, also bettered conditions by enforcing the old regulations for lighting and cleaning the streets by the householders. From the beginning of the eighteenth century contracts for street lighting and cleaning were made by the public authorities, and a tax to cover

1 J. Caillet, L'administration en France sous Richelieu, pp. 229 ff.

${ }^{2}$ Martin, Histoire de France, XIII, 84, 234. 
the expenses collected from the householders. About the middle of that century the candle lanterns were replaced by oil lamps. ${ }^{1}$ Street paving, however, continued to be done by adjacent property owners, and even ordinances requiring paving were not enforced against the wishes of the landowners. ${ }^{2}$ In 1716 a fire brigade with an equipment of hand pumps was organized, the first of modern times. ${ }^{3}$

Charity administration, even in Paris, was no longer under the exclusive control of the clergy. As early as 1505, the business management of L'Hôtel Dieu - which included the old institutions - passed under lay control. Later institutions were generally administered as branches of the general hospital, established in 1656, which was under the control of a commission composed of members appointed by the archbishop, lieutenant of police, the provost of the merchants, and the Parlement of Paris. ${ }^{4}$ Schools, however, continued to be under ecclesiastical control and management.

Other cities of France followed Paris in these municipal improvements. None had such imposing public works as the royal palaces and gardens of the metropolis. But the new police system was put in force in the large provincial cities, and an edict of $\mathbf{1 6 6 2}$ provided for the establishment in each city of a hospital for the aged poor, invalids, and orphans. $^{5}$ The system of government in these cities was moreover marked by a steady increase in the royal authority. The downfall of La Rochelle, in 1628, marked the end of any independent municipal life in France. Thenceforward the domain of administration by royal officials steadily increased, while the local officials in the exercise of the functions still left to them were subjected to the control of the intendants. At length, in 1692, Louis XIV established the system of selling the municipal offices. During the eighteenth century edicts restoring the right of local election and reëstablishing the system of sale followed each other in frequent succession. ${ }^{6}$

${ }^{1}$ Block, Administration de la ville de Paris, p. 430.

${ }^{2}$ Ibid., p. $333 . \quad 3$ Ibid., p. 803. $\quad 4$ Ibid., pp. 882-883.

${ }^{5}$ Martin, Histoire de France, XIII, 84.

${ }^{6}$ Pizard, La France en 1789, pp. 192-194. 
Some cities, especially those in the south, by themselves purchasing the offices, retained in their own hands the election of the local officials; but even in these cases the government was in the hands of a small oligarchy, uncontrolled by the people, and completely under the direction of the royal intendants. 1

1 De Tocquevilie, L'ancien régime, p. 68. 


\section{CHAPTER IV}

\section{The English Boroughs}

Authorities. - Ashley : Economic History, Bk. II, ch. 1. - Colby : Growth of Oligarchy in English Towns, English Historical Review, V, 633-653. - J. R. Green : History of the English People, I, 206-225, 355-358. - Henry Halda : Europe in the Middle Ages, III, 19-37, 219231. - Pollock and Maitland: History of English Law, I, 625-678. J. E. T. Rogers : Six Centuries of Work and Wages, I, 102-127 ; II, 310-338. - Mrs. J. R. Green : Town Life in the Fifteenth Century, I, chs. 1, 45. - Social England, II, 2, 8; III, 375, 560, 575. - Gentleman's Magazine, Vol. 57, 9-10, 105-107. - Geonge Roberts : Social History, (1856). - Henry Halda : Constitutional History of England, I, 4546, 264-268; II, 453-455; III, 36-47, 74-76. - MACAULAY : History of England, ch. 3. - Merewether and Stephens : History of Boroughs.J. R. S. Vines : Municipal Government in England. - Albert Shaw : Municipal Government in Great Britain. - P. Arminson: L'administration locale dans l'Angleterre.-Journal of the Royal Statistical Society, V, 97-168. - Contemporary Review, Vol. 34, 678-699. Report of the Commissioners on Municipal Corporations, 1835. - See also C. Gross : A Bibliography of British Municipal History.

\section{MEDIAVAL TOWNS}

THE development of important cities began much later in England than on the Continent of Europe. Not until the latter part of the eighteenth century was there any general urban growth, while even London did not reach one hundred thousand population until the sixteenth century. Nevertheless, the study of municipal institutions in England, which are of additional importance as the source of American institutions, begins far back in the mediæval ages. It might indeed begin at a still earlier date were it not for the lack of definite information about the first centuries after the AngloSaxon occupation. Owing to this, the origins of municipal institutions in England are far from clear; and especially the extent of Roman influence on later institutions is still 
in dispute. But it is known that during the latter part of the Anglo-Saxon period (the tenth and eleventh centuries) there were certain small, but compactly settled, communities which, in addition to the simple administrative officers of the rural township, had also a separate judiciary, having a jurisdiction equal to that of the Hundred Courts. A burh of this kind was ordinarily surrounded by a wall, and it was a local centre for what little trade there was at that time. The election of the judicial and administrative officers, and the passing of by-laws, probably occurred at an annual session of the court, which all who possessed land in the burh and paid local taxes could attend; ${ }^{1}$ though in a town dependent on a lord, the latter would appoint the officers.

The machinery of borough government in England developed mainly after the Norman Conquest, by means of charters of privileges, which correspond to the charters to the cities at this same period in France and Spain, except that the English charters were more usually secured from the king, as most of the boroughs were dependent directly on the Crown. The earliest granted, and one of the most important of the privileges in these charters, was the firma burgi, a fixed sum paid by the burgesses in commutation for all ordinary royal feudal dues (such as rents, tolls, and market dues), which had formerly been collected by the sheriffs from the individual landholders. When this grant had been given, these dues were collected by the town officers, who passed the round sum into the royal treasury; and the towns were freed from the frequent financial visits of the sheriffs, which had been, on too many occasions, opportunities for extortion. The collection of firma burgi necessitated a certain amount of machinery of government; and in most cases, though not always, the election of these officers was placed in the hands of the burgesses themselves. These privileges were granted

${ }^{1}$ Domesday Book shows that the local government of towns was vested in burgesses presided over by a bailiff ; and that all who paid scot and bore lot continued to have the privileges of burgesses as in Anglo-Saxon times. J. R. S. Vines, Municipal Government in England. 
because the lords and the king found it easier to collect their revenues in this way; but, at the same time, the establishment of the local organization set up a strong tendency in the boroughs toward unity, independence, and a demand for a better framework of government. Another privilege resembled that which had already existed in some places during the Anglo-Saxon period, - the right of establishing a local court, separate from, and in the main independent of, the Hundred and County Courts.

These three privileges - a local organization, the firma burgi, and a local judiciary - were, in most cases, conferred at the same time; and, together, form the whole field of the activity of the first boroughs of the Norman period. But beginning in the twelfth century, as trade and commerce developed and the towns gained in wealth and population, trade gilds became important factors in the local government, especially where they obtained the privilege of gild merchant from the crown, giving them a monopoly of the trade in that locality. This grant was separate from the three already mentioned, but in most cases the members of the gild were the same persons as the burgesses who held the privileges of firma burgi, of electing town officers, and holding a court.

"In 1216 the most advanced among the English towns had succeeded in obtaining, by their respective charters, and with local differences, the right of holding and taking the profits of their own courts, under their elected officers, the exclusion of the sheriff from judicial work within their boundaries, the right of collecting and compounding for their own payments to the crown, the right of electing their own bailiffs, and, in some instances, of electing a mayor, and the recognition of their merchant gilds by charter and their craft gilds by charter or fine." 1

\section{Stubbs, Constitutional History, III, 577.}

"In the early days the inhabitants of the municipal town depended on its own territory, built and maintained their walls and towers, and held reviews of their forces at the appointed times ; they elected their own rulers and officials in whatever way they themselves chose to adopt, and distributed 
During the thirteenth century many new charters were granted and new privileges appear. The privilege of return of writ, by which all royal warrants were sent direct to the borough officers, instead of through the sheriff, marked a further step in the severance of the connection between royal officers and the boroughs, and thus gave the boroughs a larger autonomy.

The representation of boroughs in Parliament occurred first in 1265, but was not definitely established until 1295. The borough members were summoned because the king found it more convenient to obtain grants of revenue (in addition to the firma burgi) at a general meeting than by negotiations with each town; and the right of representation was not regarded as a privilege until the fifteenth century. Moreover, representation served to retain the boroughs in a subordinate relation to the central government, and thus prevented the growth of independent cities and the consequent weakening of the national authority, as in Germany and Italy. On the other hand, the English boroughs retained their local authority, and were not subject to the extreme centralization which finally prevailed in France.

Down to the end of the thirteenth century the English boroughs were little more than good-sized villages. Outside of London, the largest had not over 4000 or 5000 population. ${ }^{1}$ After the middle of the fourteenth century they entered on a larger industrial development; but at the highest point of this movement, the cities were much smaller than on the Continent. At the beginning of the fifteenth century

among officers and councillors just such powers of legislation and administration as seemed good in their eyes; they drew up formal constitutions for the government of the community, and made, remade, and revised again their ordinances; no alien officer of any kind, save only the judges of the high court, might cross the limit of their liberties; the sheriff, the bailiff of the hundred, the king's tax gatherer, were alike shut out; the townsfolk themselves assessed their own taxes, levied them in their own way, and paid them through their own officers ; they claimed broad rights of justice ; criminals were brought before the mayor's court, and the town prison with its gallows testified to an authority that ended only with death." Mrs. J. R. Green, Town Life in the Fifteenth Century, I, 1-4.

${ }^{1}$ Mrs. J. R. Green, Town Life in the Fifteenth Century, I, 11, 13. 
London probably had a population of 40,000. York and Bristol, which ranked next to London, each had some 12,000; Plymouth and Coventry, some 9000 each; Norwich, Lincoln, Salisbury, Lynn, and Colchester between 5000 and 7000.1 No others had over 5000 inhabitants.

The boroughs were essentially trading communities, and the predominant factor in their public life was the local control of trade. The burgesses in each borough had a monopoly of trade, although outsiders were permitted to sell at the markets and fairs. The principal function of the municipal authorities was the survey of victuals, the regulations adopted establishing rules of quality, weight, and price. In each borough there was usually common property, such as pastures and town mills, survivals from the day of the agricultural village. In times of scarcity the municipal authorities purchased supplies of corn to be sold at cost, and in the sixteenth century large purchases were made regularly by the London authorities. Market houses and town halls were built; in a few places some street paving was done, and a primitive water supply brought from a short distance; and in the port towns wharves were constructed. But these works were all on a limited scale. In London itself the public system of water supply was very inadequate, and most of the inhabitants carried their own water from the river; and not until the fourteenth century was street scavenging by swine abolished. In some provincial cities ${ }^{2}$ scavengers were first appointed in the sixteenth century.

Until the thirteenth century the government of English boroughs had been democratic in principle, and seems to have been democratic in actual working. ${ }^{3}$ The mass of the citizens elected, in some public place, their own bailiffs, their own coroners, and their own mayor'; but no town coun-

1 Ashley, Economic History, II, 11 ; J. E. T. Rogers, in Work and Wages, gives the following estimates of towns with over 5000 population in 1337 : London, 37,000 ; York, 11,000 ; Bristol, 9500 ; Coventry, 7000 ; Norwich, 6000 ; and Lincoln, 5000.

2 E.g. Ipswich and Exeter.

3 Report of Commissioners on Municipal Corporations, Parliamentary Papers, 1835, p. 16. 
cil or other representative governing body seems to have existed. The list of freemen was continually enlarged by the admission of men connected with the town by birth, marriage, apprenticeship, or servitude. As, however, trade and the towns increased, and municipal affairs became more complicated, the large meetings of the burghers became inconvenient, and in some places committees (usually twelve or twenty-four in number) were appointed for the management of the government of the town. ${ }^{1}$ These committees were at first annually elected, but the selection was, as a matter of fact, from those burghers who by wealth or personal character were foremost in the town. The habit of reëlecting wellknown citizens was undoubtedly convenient, and seems to have become the general practice, for wherever there are definite records the same names constantly recur in the list of officials. The annual election in the assembly of the freemen thus became little more than a form, and little interest was taken in it by the populace. This apathy of the common freemen strengthened the hold of the leading burghers, and the change from free election to coöptation was not difficult to make, though in many places it was not submitted to without a struggle. The oligarchical spirit gained during the period of the Lancastrian rule and during the Wars of the Roses, so that by the close of the fifteenth century a large proportion of the boroughs of England were ruled by select bodies of citizens.

During the same period there was a tendency to a general type in the organization of borough officers, in which there was first, a chief magistrate (mayor); ${ }^{2}$ second, a staff of permanent assistant magistrates (aldermen), representing the wards by the union of which the city had been formed (as was London), or into which it had been subsequently divided (as was Winchester); third, a body of common councilmen annually elected, nominally by the inhabitants, but, in many cases, in practice by a few leading burghers.

In many of the towns, though the type of administration

1 Colby, Growoth of Oligarchy in English Tonons, p. 11.

2 The first mayor known is that of London, 1191. Stubbs, III, 579. 
was similar to that just described, it rested on a more representative basis. In these, the freemen at large still met and elected the councillors, and the freedom of the borough could be readily obtained. There was always, however, a large body of inhabitants outside this privileged class, who, in consequence, were subject to vexatious restrictions and imposts. It is not too much to say that what had been the democracy of 1200 had become the oligarchy of 1500 .

The unfranchised classes, the humbler sort of traders and artisans, were by no means satisfied with their conditions; they were, in fact, at the end of the fifteenth century, only awakening to their position and demanding the restoration of democratic government. "On all sides agitators proclaimed the rights of workers to have a voice in the organization of trade and the right of the common burghers to a share in the control of municipal affairs." 1

Unfortunately for this movement, just at this period the encroachments on popular liberty, which had hitherto been local and spontaneous within each town, were strengthened by gaining the support of the law and the Crown. The Tudor monarchs saw that they could control Parliament if they could control the borough representatives. They could control a select, self-perpetuating body much easier than the inhabitants of a town. Hence the Crown began to grant charters of legal incorporation to boroughs, ${ }^{2}$ - generally conferring or reviving the privilege of returning members to Parliament, - which vested all the powers of municipal government in the mayor and town council, nominated in the first instance by the Crown and afterward self-elected. ${ }^{3}$ In many cases this simply confirmed the existing usage; but the new legal status served in no small degree to establish

1 Mrs. Green, Town Life in the Fifteenth Century, II, 441.

2 The first formal charter of incorporation on record is that to Kingstonupon-Hull (18 Henry VI, 1439), and but few were issued before the reign of Henry VIII.

${ }^{3}$ May, Constitutional History, III, 279. A few boroughs, e.g. London, York, and Bristol, had also a separate county organization, - sheriff, county court, militia, - and were entirely beyond the control of the officials of the county in which they were geographically situated. 
firmly the control of select bodies. The juristic personality of the municipal body, conferred in the name "corporation," simply made more definite the legal position of the municipality. ${ }^{1}$

The typical constitution of an English borough, as early as the reign of Henry VII, is described by Bishop Stubbs as "a close corporation of a mayor, aldermen, and council, with precisely defined organization and numbers, - not indeed uniform, but of the same general conformation, possessing a new character, denoted in the name of corporation in its legal sense, with powers varying in the different communities, and in practice susceptible of wide variations."2 This type of municipal organization remained practically unchanged until the passage of the Municipal Corporations Act of 1835 .

\section{$1500-1800$}

In the sixteenth century the mediæval town system gave way, in every direction, to an organization of trade and industry resting on the wider basis of the national state. ${ }^{3}$ This was primarily a decline in the political importance of the boroughs, as parliamentary statutes for the control of commerce and manufactures took the place of municipal regulations. The local functions of the municipal officials were not disturbed; but, as has been indicated, these were of slight importance. It seems clear, too, that by the latter half of the sixteenth century, if not before, there was a decline in the material well-being of many provincial towns. This meant a further reduction in the extent of municipal activities, and in the importance of the municipal administration. London, however, continued to grow. It had extended

1 In 1466 the Court of Common Pleas held "that if the king gave land in fee farm to the good men of the town of Dale, the corporation was good," thus establishing the doctrine of the creation of corporations by implication, and charters of immunities and privileges of Henry III, Richard I, and John having been regarded as charters of incorporation. Merewether and Stephens, History of Boroughs, p. xxxiii.

2 Constitutional History, III, 577.

3 Ashley, Economic History, II, 42. 
beyond the walls which set the limits to the jurisdiction of the city corporation, and the population in 1550 has been estimated at $120,000.1$ The space beyond the walls was built up without any regularity of plan, while only a few of the more important streets were paved in any fashion. Even within the city limits the noise and dirt of the streets were subjects of bitter complaint. Indeed, the river was the principal route for transit across the city, and boats were the cabs and cars for the residents of the Elizabethan metropolis. $^{2}$ The water system was also inadequate; and the neglect of the corporation led to the formation, early in the seventeenth century, of a private company, which established works on the New River.

From the time of the Tudors until the accession of Charles I, the creation of new municipal corporations, for the sake of securing the authority of the crown in Parliament, went on actively. Between 1483 and 1625 the number of borough members in the House of Commons increased from 222 to 395 . In the reigns of Edward VI, Mary, and Elizabeth, sixteen new boroughs were incorporated in the county of Cornwall alone, that county being more directly subject to coercive influence through the indefinite and oppressive jurisdiction of the Stannary Court. ${ }^{3}$ Charles I, however, who tried to do without Parliament, rather than to manage them by influence, created no new boroughs; and from his accession the borough representation in Parliament remained fixed until the Franchise Reform Act of 1832.

In 1624 a celebrated election committee of the House of Commons ${ }^{4}$ declared that the elective franchises in ancient boroughs, and in all of later creation, where one of a different nature was not expressed in the charter, was of common law right, "the inhabitant householders, resident in the borough, paying scot and lot." This is of interest as showing the legal opinion of the time as to the original borough franchise; but no attempt seems to have been made to have this principle recognized in the new charters or in the re-

1 Social England, III, 375.

8 Hallam, Constitutional History, III, 39.

2 Ibid.

4 Ibid., III, 41. 
newals of old charters. The oligarchic form of municipal government remained unaltered.

During the Puritan Revolution the boroughs had been the strongholds of the Commonwealth party, and after the Restoration of Charles II it was determined to attack those which still opposed the court party. Acting under a statute for the correction of boroughs (13 Charles II), a quo warranto information was brought against the city of London in 1683 , and its charter was declared by the Court of King's Bench to be forfeited on the ground that it had exceeded its jurisdiction in the exaction of certain market tolls. After the fall of the metropolis, the threat of similar proceedings was sufficient to induce many boroughs to surrender their charters on the promise of new grants from the Crown. The new charters were all framed on the oligarchic model.

James II attempted to remodel the governing authorities of the boroughs so as to gain the control of Parliament, ${ }^{1}$ and his dealings with the corporations was one of the greatest grievances against him. His last act to restore himself in favor was a proclamation (October 17, 1688) which annulled the surrenders and revived the former charters. This did not, however, give the people in the boroughs any voice in the management of local affairs; it simply transferred the government of the boroughs from a select body favorable to James II to another select body favoring the opposition to James, and later supporting William and Mary. The boroughs seem to have been thought of mainly as instruments for controlling Parliament, and their functions in local affairs were wholly subordinated to this one end.

Indeed, in many of the boroughs the election of members to Parliament constituted the sole function of the corporations, and was the sole excuse for their existence; while only in a very few cases were the local functions of any importance. These local functions were usually confined to the care of ancient town property and the control of local constables and judicial administration. The church wardens and parish overseers had the same powers over poor relief

1 Hallam, Constitutional History, III, 74. 
and highways in the borough parishes as those in the rural parishes. Public works were almost unknown, as but few places were large enough to make the need for street paving, lighting, or an abundant water supply of great importance. In the time of Charles II there was no town in England, except London, with a population of over 30,000, and only four provincial cities contained so many as 10,000 inhabitants.

Next to London, but at an immense distance, stood Bristol, then the first English seaport and the centre of colonial trade, and Norwich, the first manufacturing town. Each had less than 30,000 inhabitants. Far below Bristol and Norwich, but still high in dignity and importance as centres of county life, came other ancient capitals of shires: York and Exeter had each about 10,000 population; Worcester and Nottingham about 8000; Shrewsbury, 7000; Gloucester, 5000 ; and Derby, 4000. Some of the modern industrial towns were emerging from the village to the town. Manchester was a mean and ill-built market town of less than 6000 ; Leeds, the chief seat of the already important woollen manufactures of Yorkshire, had not over 7000; Sheffield, Birmingham, and Liverpool had each less than 4000; Bath, at the head of English watering-places, had not over 400 or 500 houses. ${ }^{1}$

In London, however, - which in $\mathbf{1 6 8 5}$ had a population of half a million, - there was at least the opportunity for much municipal activity. For half a century it had been, next to Paris, the most populous capital in Europe, its only commercial rival, Amsterdam, having been long since outstripped. And in the seventeenth century the city of London was not merely a business centre, but also the residence of both merchant princes and nobility. The train bands, 20,000 strong, though only a raw militia, added much to the dignity and importance of the city at a time when there was no standing army. London, indeed, was to the Londoner of that time what Athens was to the Athenian of the age of Pericles, what Florence was to the Florentine of the fifteenth century.

Nevertheless, municipal conditions in London were in a

1 Macaulay, History of England, ch. 3. 
state which to-day would be considered intolerable. After the great fire in 1666, a comprehensive plan for reconstruction was drawn up by the famous architect, Sir Christopher Wren, providing for broad streets, spacious squares, and wide quays along the Thames; but building in accordance with these plans was not enforced, and the opportunity was lost. Not only did the narrow streets and crooked alleys remain, but little effort was made to render them even passable. The pavement was detestable; all foreigners cried shame upon it. The drainage was so bad that in rainy weather the gutters soon became torrents. Several facetious poets have commemorated the fury with which the black rivulets roared down Snow Hill and Ludgate Hill, bearing to Fleet Ditch a vast tribute of animal and vegetable filth from the stalls of the butchers and green-grocers. ${ }^{1}$

Open spaces within the town were receptacles for offal and cinders, for dead cats and dead dogs. The houses were not numbered, and, until the end of Charles II's reign, most of the streets were in profound darkness. Falls, bruises, and broken bones were of frequent occurrence. Pails were emptied from upper windows with little regard for those passing below. Sewers for the disposal of waste were absolutely unknown. Thieves and robbers plied their trade with impunity; while the dissolute youth of the better classes amused themselves at night by breaking windows, upsetting sedan chairs, beating quiet men, and offering rude caresses to pretty women. It is true, there was an act of common council which provided that more than one thousand watchmen should be constantly on the alert from sunset to sunrise, and that every inhabitant should take his turn of duty. But few of those who were summoned left their homes; and those few generally found it more agreeable to tipple in ale-houses than to pace the streets.

A system of street lighting was introduced in London in 1685 , through what would now be called a franchise. Letters patent were issued to one Edward Heming, who bound himself to place a light before every tenth house from

1 Macaulay, History of England, ch. 3. 
Michaelmas to Lady Day, to be lit on dark nights until midnight. Ten nights in each month were considered "light." The contractor was empowered to levy a rate of six shillings a year from all housekeepers who paid poor rate, and from all owners of houses of a rental value of over $£ 10$ per year, unless they hung out a lantern or candle before their doors. The contractor agreed to pay the city $£ 600$ a year.

This system, with all its deficiencies, from the modern point of view, was a large improvement over previous conditions. Nevertheless, for many years there remained extensive districts with no lamps, and hence without lights even for the limited periods provided for by the system. In 1736 a further improvement in London street lighting was established. The mayor and aldermen of the city were authorized to erect glass lamps to be lit all night, and to levy a rate for their maintenance. More than 15,000 lamps are said to have been erected in a few years; and it has been calculated that in place of 750 hours a year, the London streets were now lit 5000 hours.

In 1722 a second private water company was formed, and authorized to furnish an additional water supply to the metropolis. About the middle of this century, when the novelist Fielding was magistrate at Bow Street Court, some improvement was made in the police within the city, and street robbery and rioting were suppressed. The street pavements, however, throughout the eighteenth century remained not merely poor, but scandalously inferior to that of the great towns on the Continent. ${ }^{1}$

\section{REFORM OF THE CORPORATIONS}

After the revolution of 1689 the interference of the Crown with corporate privileges - " the intrusion of prerogative" ${ }^{2}$ - had ceased; but municipal self-government was as little respected as before. The close corporation had come to be regarded as the typical form of municipal government,

1 Lecky, England in the Eighteenth Century, I, 615.

2 May, Constitutional History of England, III, 280. 
and the charters granted during the Georgian period followed the model of the preceding period. Even where the powers of government were not expressly limited to a small body of persons, custom and usurpation restricted it either 'to the town council or to that body and its own nominees, the freemen. The House of Commons, by decisions in controverted election cases, and also the courts of law, continued and supported the established tasage. Composed of local, and often hereditary, cliques and family connections, these corporations were masters of the situation. The governing authorities, elected for life, often self-elected, found it not difficult to consolidate their personal interests, and they were thus free to act without any sense of responsibility to the communities.

Meanwhile the towns were growing in population and wealth. The development of commerce, following the revolution of 1689 , promoted the growth of seaport cities; and after the middle of the next century the introduction of the factory system of industry started the rapid growth of manufacturing centres. The population of London increased by 1801 to 865,000 . But of greater significance are the facts in regard to urban centres outside of the metropolis. Where in 1685 there had been only four towns of over 10,000, and none over 30,000, in 1801 there were in England fourteen towns with over 20,000 , aggregating 641,000 ; while including Scotland and Ireland there were twenty-four towns with from 20,000 to 170,000 population each, aggregating $1,210,000$. Including London, the population of cities of over 20,000 in the United Kingdom was more than 2,000,000, ${ }^{1}$ a larger number than were to be found at that time in the cities of this size in any other country.

The existing system of municipal government provided no means for supplying the most essential needs of these urban communities. The more populous and wealthy towns, however, began to seek a remedy, in their individual cases, by applying to Parliament for special legislation. Beginning as early as the reign of George II, numerous special acts

1 Weber, Grovoth of Cities, pp. 46-66. 
were passed authorizing local improvements in various cities, more especially providing for paving, lighting, and cleansing streets, and establishing a body of night-watchmen, with authority to levy local rates for these purposes. In some cases these new powers were conferred upon the existing municipal corporation, but more often on special and independent boards; and in the London parishes outside of the city boundaries it was frequently the parish vestry which received the authority. This added a confused chaos of authorities to the other difficulties of the situation, without adequately meeting the new urban conditions, while in many towns little or nothing was accomplished in the way of municipal improvements.

Meanwhile the urban movement was gaining an increasing momentum, and municipal problems were becoming steadily more pressing. Two distinct reforms were essential. First, a radical reconstruction of the municipal corporations; and second, an equally radical development in the conception of the functions and duties of the corporations. The second reform could come only after the first.

The corrupt corporations were, however, the stronghold of parliamentary interest and corruption, and to this $t$ owed their long immunity. "The unreformed House Commons was, in fact, dependent on the unreformed corporations. The unreformed corporations were the cause and consequence of the unreformed House of Commons." 1 "A great number of corporations," say the commissioners of 1835,2 "have been preserved solely as political engines, and the towns to which they belong derive no benefit but much injury from their existence. To maintain the political ascendency of a family has been the one end and object for which the powers intrusted to those bodies have been exercised. This object has been systematically pursued in the admission of freemen, resident or non-resident; in the selection of municipal functionaries for the council and the mag-

1 Walpole, History of England since 1815, IV, 36.

2 Report of the Commissioners on Municipal Corporations, Parliamentary Papers, 1835, p. 34 . 
istracy; in the appointment of subordinate officers and the local police; in the administration of charities intrusted to the municipal authorities; in the expenditure of corporate revenues; and in the management of corporate property."

Such corporations were safe so long as the notorious abuses of parliamentary representation were tolerated; but they received their death blow from parliamentary reform. The Act of 1832 wrested from the corporations their exclusive electoral privileges and restored them to the people. By this act many of the smaller boroughs were disfranchised. Some of these had no funds of their own, their expenses being defrayed by their patron, who naturally declined to go on contributing to their support when he ceased to derive any benefit from the borough. In these cases the borough died a natural death, the corporation having no means of sustaining municipal institutions. In other boroughs the parliamentary boundaries were rearranged and the franchise was bestowed on all occupiers, whether freemen or not, thus sweeping away the political abuses of the boroughs.

The condition of the municipalities naturally forced itself on the consideration of the first House of Commons elected nder the Reform Act of 1832. Petitions for their reform were presented from various places, and a royal commission was appointed, which undertook a searching and careful inquiry into the nature and conduct of municipal institutions. They divided the country into districts and made local inquiries into each municipality. Their investigation was not finished until 1835, and their report then published was one of the longest and most elaborate documents that had ever been published under the authority of Parliament. It placed the whole history of corporations before the public, and roughly exposed the manifold abuses of irresponsible power.

In all, 285 corporations were discovered; but 39 of these were municipal only in name, from 8 no reports had been obtained, and London, being the subject of a special report, was omitted from the general account. This left 237 corporations whose affairs were subject to investigation. ${ }^{1}$ The

1 Report, p. 91. 
central fact brought out was that the great mass of the townspeople were excluded both from corporate privileges and also from any share in the town government. The corporate privileges possessed by the freemen, in addition to that of voting in parliamentary elections, consisted in exclusive trading rights, exclusive rights of pasturage in particular commons, and exemptions from tolls and market dues. The value of pasturage enjoyed by a freeman at Beverly was estimated at $£ 25$ a year. ${ }^{1}$ In Newcastle the exemption from tolls saved one merchant $£ 450$ a year. The methods of acquiring the title to "freedom" were many, and varied greatly in the different corporations. In general, however, they could be acquired in the following ways: by birth (sons of freemen were freemen), marriage (sons-in-law of freemen were freemen), servitude (apprentices of freemen were freemen), purchase, and election by the corporation.

The last two had become the easiest methods, and the number of freemen in the boroughs was very small. In 25 boroughs the number could not be ascertained, but in the remaining 212 , which had a population of $1,800,000$, the total number of freemen was but 88,509. Ninety-two boroughs had less than 50 freemen each. Liverpool, with a population of 165,000 , had 5000 freemen ; but Cambridge, with 20,000 inhabitants, had only 194; and Portsmouth, with 46,000 inhabitants, only 102. In Marlborough, a town of 3500 , the number of freemen was 15 , exactly the number of municipal offices. In other towns, while the total number of freemen appeared to form a somewhat larger portion of the population, a large portion were non-residents. In Ipswich, a town of 20,000 , with 1130 freemen, 760 of the latter were non-residents; and in Plymouth, with 31,000 inhabitants, 145 out of 437 freemen were non-residents. Nor did the freemen make up in character what they lacked in numbers. They were frequently corrupt and inferior, the corporations admitting large numbers of such when a general parliamentary election was anticipated, and the number of freemen on their side was small, so as to insure the election of their candidate.

1 Report, pp. 21, 23. 
But even the freemen had rarely any share in the government. Of the 211 corporations which had an active governing body, that body was elected by the freemen in but twelve. In 186 the government was self-elected, and in the others it was appointed by one or two patrons. The typical constitution was still that of a mayor, aldermen, and common council. In small boroughs the mayor was practically intrusted with the sole authority, and in many boroughs any audit or check on his accounts was unknown, although it was notorious that the funds of the boroughs were perverted from their proper uses. Soon after the disfranchisement of Grampound the mayor left the borough, took the accounts away with him, and did not think it necessary to reappear. ${ }^{1}$

The councils were no less corrupt than the mayors. The revenues of the boroughs were but partially applied to municipal purposes, and were frequently expended on feasting and on salaries of unimportant officers. Pluralism in holding lucrative sinecure offices was common. The property of the borough was frequently let to members of the council under a rent or at prices far below its value." "Charities were despoiled and public trusts neglected; jobbery and corruption in every form was fostered." 3 The property of the boroughs was occasionally not sufficient for the corrupt and extravagant expenditures of these local oligarchs, and some corporations were absolutely insolvent. Few corporations admitted any obligation to expend their surplus revenue for public purposes; and such expenditure was regarded as a spontaneous act of private generosity. ${ }^{4}$

A great majority of the boroughs had local courts of justice, and here, too, the most whimsical abuses existed. The populations had commonly outgrown the limits of the corporate authority, leaving large, populous areas exempt from its jurisdiction. The powers of the courts had no relation to the importance of the towns; in Bath, with a population of 50,000 , the local magistrates could not try a felony, while in Dunwich, where lived 232 persons, the local courts

\footnotetext{
1 Report, p. 37.

2 Ibid., p. 45.

${ }^{8}$ May, Constitutional History of England, III, 281.

- Report, p. 45.
} 
could sentence a man to death. Illiterate magistrates were common; even the recorder was not necessarily a lawyer. The town clerk in some cases exercised several incompatible functions: frequently he acted as recorder when that official did not consider it necessary to perform his duties ; ${ }^{1}$ sometimes he acted as mayor; sometimes as attorney; and at times the same man was judge, prosecutor, and selector of juries. ${ }^{2}$

As a result of their inquiries the commissioners announced, as their conclusion, "that there prevails among the inhabitants of a great majority of the incorporated towns a general and, in our opinion, a just dissatisfaction with their municipal institutions, and a distrust of the self-elected municipal councils, whose powers are subject to no popular control, and whose acts and proceedings, being secret, are unchecked by the influence of public opinion." 3

A bill founded on the recommendations of the commissioners was at once prepared and introduced in the House of Commons by Lord John Russell. The bill was to apply to 183 boroughs - London was not included. It proposed to sweep away the abuses laid bare by the report; to annul all charters and customs inconsistent with its provisions, and to provide a uniform constitution for all boroughs to which it applied. The governing body in each borough was to consist of a mayor and council - the councillors to be elected by residents who had been ratepayers for three consecutive years. The pecuniary rights of existing freemen were to be preserved, but were not to be continued to their descendants. All exclusive trading privileges were to be abolished. A recorder would be nominated by the Crown for any borough providing an adequate salary, the recorder to be in every case a barrister of five years' standing. For the management of charity estates, special committees were to be chosen, not from the council, but from the burgesses. ${ }^{4}$

The bill met with great opposition on the part of the Tories.

1 The recorder of Carmarthen held his office for fifty years without once visiting the borough.

2 Report, pp. 39-41.

3 Ibid., p. 49.

- Hansard's Parliamentary Debates, 3d Series, XXVIII, 541-558. 
Lord Eldon thought it even more iniquitous than the Reform Act. But Sir Robert Peel declared himself in favor of a large measure of reform, and the bill went through the Commons by a safe majority. In the House of Lords important amendments were added, retaining the trading privileges and parliamentary franchise, making only those ratepayers who paid the highest rate of assessment eligible for election to the council, introducing aldermen elected for life into the councils, and other changes. Lord Ellenborough declared that the corporation bill had been converted into a "fully consistent and constitutional conservative reform." 1

This action of the House of Lords irritated the House of Commons, and threats to stop the supplies if the corporation bill was not passed had been heard. Some members of the Commons even went so far as to threaten the House of Lords with extinction. When the reconstructed bill was sent down to the House of Commons, Lord Russell agreed to allow the parliamentary franchise of freemen to stand, but not their trading privileges; on the matter of life aldermen and property qualifications for councillors, he was willing to compromise, but on all other important amendments he adhered to the original bill. Peel supported his Tory colleagues against the ministry in but two minor points; on all the important amendments he occupied the same position as Russell. Peel's stand forced the Lords to give way, a compromise thoroughly satisfactory to the advocates of reform was reached, and the corporation bill became law.

The Act of $1835^{2}$ applied to 178 cities and boroughs, but provision was made for the incorporation of new boroughs under the general act. The governing body was still to consist of a mayor, aldermen, and councillors; but instead of the self-elected body with indefinite terms, the councillors were to be elected for a term of three years, one-third

1 Hansard's Parliamentary Debates, 3d Series, XXX, 1034.

$25 \& 6 \mathrm{Wm}$. IV, c. 76 . This applied only to England and Wales. Seventy Scots boroughs had been reconstructed in 1833 on the same general lines. Subsequent legislation on municipal affairs was generally applied to Scotland by separate acts passed at the same or the following session of Parliament. 
being chosen each year, and the municipal franchise included all the ratepayers in the borough; the aldermen were to be chosen by the councillors, one-half every three years for a term of six years; and the mayor was to be elected annually by the council. The mayor, aldermen, and councillors formed together the common council, which sat as one body. The act also provided for two auditors and two assessors to be elected annually by the burgesses in March. The town clerk, treasurer, and other officers were within the appointing power of the common council. A property qualification was required for councillors, aldermen, auditors, and assessors. The council was authorized to levy a borough rate when other funds did not prove sufficient. The jurisdiction, powers, and rules of procedure of the local courts were carefully detailed. Existing rights of property, beneficial exemptions, and the parliamentary franchise were reserved to freemen and their heirs; but in future no freedom could be acquired by gift or purchase.

M. D. Chalmers, in his well-arranged book on Local Government, in the English Citizen Series, sums up the reforms effected by the Act of 1835 in these words: "It took away magisterial powers from the aldermen, provided that the recorder should be a trained lawyer, abolished all trading monopolies, exemptions, and restrictions, shortened the tenure of elective officers, gave the franchise to all inhabitant ratepayers, and provided for the honest administration of corporate funds and the efficient discharge of municipal duties." 1

By this Act, there was provided for municipal government in England a permanent foundation and a stanch framework. But it has not been allowed to become a stereotyped code, incapable of being changed to suit new circumstances. From time to time, as experience showed the way, new enactments amending the law of 1835 were made by Parliament. These, in some cases, made slight modifications in the structure of borough government; in other cases, further provisions were made to guard the purity of elections; but more usually these

1 Chalmers, Local Government, p. 73. 
acts extended and altered the scope and functions of the town councils. Several scores of such additional laws were placed on the statute books between 1835 and 1882. To codify these various statutes relating to the incorporated towns, a carefully drafted statute was passed, in 1882, which consolidated the existing laws into a simple and intelligible municipal code.

\section{MUNICIPAL EXPANSION}

The Municipal Corporations Act of 1835 established selfgovernment in the English boroughs. In connection with the later amending acts it enlarged the powers of the councils over the maintenance of order and the administration of justice. But one looks in vain through the municipal code of 1882 for any authority given to the town councils over such matters as street improvements, public lighting, sewerage, waterworks, and parks, which are, in fact, to-day their most important functions. Moreover, the municipal boroughs constitute by no means all the urban communities in England; there are, in addition to the three hundred boroughs, over twice that number of populous towns, in which the whole local government is carried on without any reference to the Municipal Corporations Acts of 1835 and 1882. A complete survey of urban government requires a consideration of the legislation under which these smaller towns are governed, and under which the town councils of the boroughs find authority for their large municipal undertakings.

Mention has already been made of the fact that, owing to the corruption and mismanagement of the corporations, it had been the custom not to rely on them for the management of the town; but additional powers of local government were granted, from time to time, by local acts of Parliament for various purposes, not to the officers of the corporation, but to trustees or commissioners distinct from and independent of them; and while the former had the nominal government, the efficient duties and responsibilities were transferred to the latter. By 1847 nearly two hundred such local acts had been passed, conferring on populous places powers of local 
government, directed mainly, at first, toward the paving, lighting, and cleaning of streets, and otherwise improving the districts; but in all later instances the importance of sanitary regulations and local by-laws was also recognized, and authority given accordingly. In the older local acts the improvement commissioners were appointed by name in the act, with power to appoint their successors; in later acts, after the reform of the corporations, the system of election by the ratepayers was introduced. Usually one-third of the commissioners was elected each year.

These special acts, each prepared for a particular case, without reference to similar acts for other localities, gave widely different powers to the various bodies of commissioners. The first step toward more general legislation was the Lighting and Watching Act of 1830. ${ }^{1}$ The Reform Parliament replaced this by the Act of $1833,{ }^{2}$ which is still in force, though later acts have superseded it in most districts. The Act of 1833 was permissive, that is, its provisions affected only those parishes in which they were adopted by resolution of the vestry duly convened for that purpose. In parishes which adopted the act the ratepayers were enabled to choose inspectors, who appointed watchmen and provided for public lighting, with authority to construct gas-works.

In 1840 a select committee of the House of Commons on the health of towns drew attention to the evils of interments in populous cities, the importance of water supply, the want of open spaces in crowded cities, the necessity of some supervision over common lodging-houses, and the advantages of public baths. It recommended, further, health laws and the creation of local boards of health. ${ }^{3}$ Other reports on the sanitary condition of populous places ${ }^{4}$ led to the appointment, in 1843, of a royal commission, whose report showed the inadequacy of the existing laws on drainage, resulting in uncleanliness, deficiency, and impurity of water, especially in the poorer parts of the towns; while improvements, when made, were at the expense of the owners or occupiers,

111 Geo. IV, ch. 27.

$23 \& 4$ Wm. IV, ch. 90 .
8 Parliamentary Papers, 1840, Vol. XI.

- Ibid., 1843, Vol. XII. 
whereas comprehensive plans could have been carried out for one-quarter the cost. ${ }^{1}$

"Of the 50 towns visited on behalf of the commission, the drainage was reported bad in 43 , the cleansing in 42 , the water supply in 32. In Liverpool 40,000 and in Manchester 15,000 of the working class lived in cellars, dark, damp, dirty, and ill-ventilated; Nottingham contained 11,000 houses, of which 8000 were built back to back and side to side, so that ventilation was impossible. . . Even in Birmingham, then as now a model town, the water supplied to some of the poorer districts is described as being 'green as a leek.' The result of this state of things was clearly seen. Whilst the death rate in country districts was 18.2 per thousand, in towns it was 26.2; in Birmingham and Leeds it was 27.2; in Bristol, 30.9; in Manchester, 33.7; in Liverpool, 34.8."'2

There were frequent instances of local commissioners neglecting to carry into effect the full powers conferred on them. But, in addition, the local acts were, for the most part, now entirely inadequate; they rarely comprised the whole district covered with buildings, and most of the early acts had no provision for drainage. Probably in many cases the provisions of the acts had been adequate for the conditions at the time of their passage; but the towns had been growing rapidly, and these provisions were now far from sufficient. The total population in communities of over 20,000 inhabitants had all but trebled in the forty years since the beginning of the century. In 1801 there had been 25 cities of over 20,000, aggregating 2,000,000, in the United Kingdom; in 1841, there were 68 cities in this class, with a total population of $5,800,000$.

The commission of 1843 recommended that the local authorities should be given increased powers; that the arrangements for drainage, cleansing, regulating buildings, and water supply should, in every case, be under one authority; that there should be compulsory local taxes for

1 Parliamentary Papers, 1844, Vol. XVII.

${ }^{2}$ Edinburgh Review, Vol. 173, 1891, p. 69. 
water supply, as well as sewerage; and that there should be a critical inspection of sanitary improvements in the towns by a central authority.

No legislation resulted from these reports until the enactment, in 1847, of a series of statutes known as the Clauses Acts. The most important were the Town Improvement Clauses Act, the Town Police Clauses Act, the Waterworks Clauses Act, and the Gas-works Clauses Act. These statutes consolidated and generalized the provisions usually found in the special acts, and it was provided that the model clauses thus furnished could be adopted by reference in subsequent special acts. By this means it was made easier for the towns to frame bills for their needs, while the special statutes would be framed on the same general plan.

A year after the passage of these Clauses Acts a comprehensive measure on the subject of sanitary legislation became law. It was the first great general law on the subject, and introduced large improvements in urban conditions. This statute $^{1}$ created a general board of health, ${ }^{2}$ empowered to create - through the machinery of an order in council local boards of health on the petition of the ratepayers. This method of securing a local administrative body, and adopting the provisions of the act, was less expensive and much easier than the former system of obtaining a special act of Parliament, and so facilitated the creation of such boards on local initiative. Moreover, the General Board of Health was empowered to establish local boards on its own motion. In municipal boroughs the town council was, in all cases, constituted the local board, whereas formerly separate boards had frequently been established, with a division of power and responsibility which had not proved advantageous to the welfare of the towns. In places not municipal boroughs, the local boards were elected by the ratepayers, under the following system of plural voting.

Every person rated for the poor rate as owner or occupier at a ratable value of less than $£ 50$ had one vote; where the

1 Public Health Act, 1848, 11 \& 12 Vict., ch. 163.

2 To continue five years, and afterward renewed until 1858. 
ratable value of the property was between $£ 50$ and $£ 100$, the rate-payer had two votes; between $£ 100$ and $£ 150$, three votes; between $£ 150$ and $£ 200$, four votes; between $£ 200$ and $£ 250$, five votes; over $£ 250$, six votes. Moreover, any person who was owner and at the same time bona fide occupier of the same property "shall be entitled to vote both in respect of such ownership and of such occupation." In this way one person might have as many as twelve votes. Official ballots - voting papers - with the names of all persons nominated were delivered in person to the voter three days before the election. The voter indicated his choice and signed the ballot, which was called for by a collector on election day. This system of plural voting with an open ballot continued in force for all local elections - except for town councils in municipal boroughs and, after 1888, for county councils until 1894.

Local boards and town councils were given power to construct and manage sewers and drains, wells, pumps, water and gas works, and slaughter-houses; to regulate offensive trades and remove nuisances; to regulate dwellings and lodging-houses; to pave and repair streets; to provide burial grounds and recreation grounds. They were also authorized to purchase land and levy rates sufficient to carry out their functions. The General Board of Health was empowered to appoint inspectors and, in other ways, to see that the provisions of the act were put in force by the local authorities. The powers given were, in fact, freely used. More especially, the construction of extensive municipal water systems in the large cities began about the year 1850; while in other respects municipal conditions were greatly improved.

The Act of 1848 was frequently amended and extended by later legislation, and a few of the more important amending acts may be especially mentioned. The Nuisances Removal Act of $1855^{1}$ consolidated the laws relating to the removal of nuisances, which, curiously enough, was considered an entirely distinct subject from that of sanitary legislation. 
This statute made a fresh and extended definition of nuisances, and increased the powers of local authorities. The Local Government Act of $1858^{1}$ "greatly extended local powers for the execution of sanitary works in such urban districts as adopted it, and gave, in fact, most of the requisite powers of police and municipal government, if only they were duly sought and duly used." 2 This statute also enabled a local board to be created, with all the powers under the Act of 1848 and its amendments, by the resolution of the ratepayers in any district having a defined boundary, without the necessity of any sanction by the central authority. The General Board of Health, which had been strongly opposed, was at this time allowed to expire; and such powers of central control as were retained were divided between the Home Office and the Privy Council.

A statute of 1856, not connected with the health legislation, led to a great improvement in the police of the cities, by providing for grants from the central government to those police forces which came up to the standard of the inspection department established in the Home Office.

The growth of urban communities in the United Kingdom had become even more marked after the fourth decade. The opening of railways, the expansion of commerce following the free trade legislation, and the concomitant development of the iron industry combined to swell still further the tide to the cities. From 1841 to 1871 the number of cities with over 20,000 population increased from 68 to 120 , and the aggregate population in such cities from $5,800,000$ to $11,200,000$. There were by the latter date 16 cities with over 100,000 population, in addition to London. The metropolis had 3,250,000, Glasgow had over 500,000, while Birmingham, Manchester, and Liverpool had each over 300,000 .

During the years immediately following 1870 there appeared some significant advances in the activities of the municipal authorities in the larger cities. Not only were the former functions greatly extended to meet the demands

$121 \& 22$ Victoria, ch. 98.

2 Report, Commission of 1871, p. 10. 
of increased population, but also new fields of action were undertaken on a large scale. The most striking feature was the schemes of physical betterments in some of the larger cities, involving the reconstruction of both streets and buildings in large areas of the cities, to secure more sanitary conditions. It is also in this period that street railways were constructed in the British cities, under franchises and contracts with the town councils.

These new developments were accompanied by important parliamentary legislation. In 1870 the Tramways Act was passed, regulating the conditions of street railway franchises. In 1871 the central control of local government was placed on a more systematic basis by the creation of the Local Government Board, which received authority formerly vested in the General Board of Health, as well as the powers of the Poor Law Board. In 1875 all of the "sanitary" statutes, embracing the Act of 1848 and forty-six other acts, were consolidated and enacted in a comprehensive code. This Public Health Act of $1875^{1}$ also included additional changes in the law, in some cases removing difficulties of interpretation, and in others adding to the existing powers and obligations of the Local Government Board and the local authorities. This act has, in turn, been frequently supplemented by later statutes amending and extending the functions and authority of the local boards and town councils. But the Act of 1875 is still the law of general application relating to sanitary matters. In fact, it is the basis of the most important functions of the borough councils and of the local government in other urban districts.

An important change in the name and in the method of electing the local authority in urban districts not boroughs was made by the Local Government Act of $1894^{2}$ (Parish Councils Bill). Plural and open voting were abolished entirely, and each elector now has one vote and no more. The urban local boards are called Urban District Councils, and the term of office of the councillors is fixed at three years, one-third retiring each year, except in special cases

138 \& 39 Victoria, ch. 55.

256 \& 57 Victoria, ch. 73. 
where the county council may direct that the whole council shall retire together. In the municipal boroughs the town council remains the urban district council, and its powers and functions as such are governed by the same legislation which controls the councils in urban districts not boroughs.

The functions of the urban district councils may be briefly recapitulated: they include sewerage, drainage, water supply, gas-works, inspection and prevention of nuisances, inspection and regulation of lodging-houses, hospitals, cemeteries, the maintenance, cleansing, lighting, and improvement of streets, the regulation of traffic, and town improvements. The borough councils have, in addition, the management of ancient borough funds and, in most cases also, the control of the local police, subject to the inspection of the Home Otfice.

Poor relief and the public schools are in no case functions of the English municipal borough. The work of poor relief is administered under the control of the Local Government Board, by boards of poor law guardians elected in districts known as poor law unions, this system dating from 1834. The poor law unions, except in a few of the largest cities, include rural as well as urban territory. The public school system dates only from 1870, and the schools in each city or school district are under the control of a board, elected entirely independent of the town council or other local authority.

While a large part of the municipal work in London has been accomplished through the adoption of the general sanitary statutes, by parishes or union of parishes, the need for a central administration for the entire metropolitan district in certain matters has required additional legislation. The first important step was the creation of the Metropolitan Police, in 1829, which is under the direct control of the Secretary of State for the Home Department. In 1855 the Metropolitan Board of Works, composed of 46 delegates from the parish and district boards, was created to construct and manage main drainage works, bridges, main thoroughfares, parks, and other general improvements, and to control 
the fire brigade. In 1888 this board was abolished, and its place taken by the London County Council, a body of 137 members, consisting of 118 councillors, elected directly by the ratepayers, and 19 aldermen, elected by the councillors. The County Council, in addition to the functions of the former Board of Works, has a large variety of duties over the administrative county of London. In 1900 the 41 metropolitan parishes and districts were consolidated into 28 municipal boroughs, whose functions are, however, limited by the powers of the County Council. In addition to these authorities there is a school board of 55 members, 30 boards of poor law guardians within the county of London, and the ancient and still active city corporation.

The concentration of population in towns, which gave rise to the pressing municipal problems in British towns early in the nineteenth century, has continued with unabated force. Towns of 20,000 and over have increased from 25 in 1801, 68 in 1841, and 120 in 1871, to 210 in 1891; and the aggregate population of such towns has grown from 2,000,000 in 1801 and 5,800,000 in 1841 to almost 18,000,000 in 1891. In 1901 the population of the administrative county of London is 4,536,000; Glasgow has nearly 760,000; Liverpool, 684,000; Birmingham and Manchester, each over 500,000, the total population of the urban area of which Manchester is the centre being nearly $1,000,000$. Leeds, with 428,000, Sheffield, with 380,000, Bristol, with 328,000, and Edinburgh, with 316,000 , rank next in importance. Twenty-eight other towns, each with over 100,000 inhabitants, bring the aggregate population in cities of this size up to $12,000,000$, nearly thirty per cent of the total population of the United Kingdom. The administration of municipal affairs in such places presents manifold and weighty problems. And we shall find that the British cities, which were the first to feel the modern urban movement, have been in many respects the most successful in meeting the needs of the situation. 


\section{CHAPTER V}

\section{Municipal Development in the United States}

Authorities. - Johns Hopkins University Studies in History and Politics. D. F. Wilcox : Municipal Government in Michigan and Ohio.-S. E. SParling: The Government of Chicago. - E. D. Durand : The Finances of New York City. - F. J. Goonsow : Comparative Administrative Law. - Municipal Home Rule. - Municipal Problems. - Proceedings of Conferences for Good City Government.-J. A. FaIrLIE : In Municipal Affairs, II, 341.

\section{THE COLONIAL PERIOD}

American municipal government has its historical origin in the chartered boroughs or municipal corporations ${ }^{1}$ established in several of the English colonies during the seventeenth and eighteenth centuries. Records show the creation, by charter, of twenty such corporations, but of these two had merely an ephemeral existence, ${ }^{2}$ and three others were of slight importance during the colonial period. ${ }^{3}$ Of the active boroughs, the first in time was New York, which dates its civic existence from 1653, became an English municipal corporation in 1665, and received its first charter in $\mathbf{1 6 8 6 .}$ Albany received its charter in the same year as New York; the first recorded charter of Philadelphia was granted in 1691 ; four smaller boroughs were incorporated in Pennsylvania, ${ }^{4}$ and five in New Jersey ${ }^{5}$ while in the Southern colonies there were Annapolis in Maryland, and Norfolk,

1 The word "borough" is used as a general term for the municipalities of the colonial period to emphasize their connection with the English boroughs; for later periods the present American custom is followed by the use of the word "city."

2 Agamenticus (1641) and Kittery (1647), both in the province of Maine.

${ }^{\mathbf{3}}$ Germantown, Pa., Bath, N.C., and Trenton, N.J.

4 Germantown, Chester, Bristol, and Lancaster.

5 Perth Amboy, New Brunswick, Burlington, Elizabeth, and Trenton. 
Williamsburg, and Richmond in Virginia. The latest charter in colonial times was that to Trenton, N.J., in 1746.

These charters granted by the provincial governors were on the same legal basis as the royal charters to English boroughs, and the earlier theory seems to have been that the municipal corporations were not subordinate to the assemblies. The form of organization provided resembled in its general features the English municipal organization of the same period. The principal authority was the common council, composed of the mayor, recorder, aldermen, and assistants, or councilmen. These acted as a single body, a quorum requiring the attendance of the mayor and a specified number of both aldermen and councilmen. The mayor and aldermen had certain judicial functions in addition to their duties as part of the common council, which had control of all matters of administration.

In one respect most of the American colonial boroughs differed from the prevailing English system. Only in Philadelphia, Annapolis, and Norfolk was the governing authority made a close corporation. In these places the aldermen and councilmen held their positions for life, and vacancies among the aldermen were filled by the corporation (i.e. by the common council), and for councilmen by the mayor, recorder, and aldermen. In all the other boroughs, however, the councilmen and, except in Perth Amboy and Trenton, the aldermen also were elected by a popular vote under a franchise which everywhere included all of the well-to-do classes, and generally a large proportion of the residents, though in no case was manhood suffrage established. Elective aldermen and councilmen were chosen for terms of one year, except in Elizabeth, where the term was three years, and Trenton, where, strangely enough, it was for life.

The mayor, however, was in no case chosen by popular vote. The close corporations had, as in English boroughs, the power of electing their mayors from the existing aldermen; and the elective council in Elizabeth had the same authority. In the other boroughs, where the members of the council were 
elected, the mayor was regularly appointed by the governor of the province, ${ }^{1}$ and the choice fell frequently upon a former alderman. Whether elected or appointed, the mayor's term was in all cases a single year ; but in practice reappointments were frequent, and during the latter part of the colonial period the mayors of New York and Albany generally held the position continuously for ten years.

Special charter powers of the mayor were not of great importance. He had no power of appointment unless delegated by the council; and he had no veto over the acts of the council - in Philadelphia he did not even have a vote. But he presided at all meetings of the council, and his presence was necessary to constitute a quorum; he was charged with executing the ordinances of the council; in New York and Albany he controlled the licensing of taverns; and he frequently held ex officio minor offices. These conditions tended to centre the administration to a considerable degree in his hands; while his influence in municipal affairs was further increased by the fact that he was usually a man of much experience in the affairs of the corporation, and that in practice he held office for a number of years. Thus, even during the colonial period, the mayor became something more than a dignified figurehead, and was a real force in the municipal government.

The functions of these colonial boroughs, like those of the English municipal corporations, included judicial, legislative, and administrative duties. The judicial functions were of comparatively greater importance than at present. The mayor, recorder, and aldermen were each justices of the peace during their term of office, and as such had the usual summary jurisdiction over petty criminal and civil cases. In addition to this the mayor, recorder, and aldermen of each borough sitting together formed a local court of record, with stated sessions for the trial of more important cases, and in some instances the same officials were also members of the

1 During the Leysler troubles in New York province, mayors were elected by popular vote in the cities of New York (1688 and 1689) and Albany (1689); but appointment was restored in 1690 . 
county courts. The councilmen or assistants had no share in the exercise of these judicial functions.

Legislative powers of the municipal corporations were limited to the authority to establish local ordinances, not repugnant to the laws of England or the assembly of the province. These were mainly police ordinances for the maintenance of order and the prevention of nuisances, such as rules against fast driving, regulating the cleaning and paving of streets by the householders, and requiring precautions to be taken against fires. But there were also ordinances fixing the prices of food (a survival of the survey of victuals) and (in Albany) ordinances regulating trading with the Indians; while others attempted to guard the morals of the community by requiring the observation of the Lord's Day and (in Philadelphia) forbidding theatrical performances.

The administrative powers of the colonial corporations, like their legislative authority, were almost exclusively over matters of special interest to the small urban communities, and seldom included any of those matters for which there was a general system over the entire province. Thus the management of the militia, the administration of the poor laws, and the assessment of the taxes levied by the assemblies were in no case subjects of municipal action. The borough authorities were all empowered to hold markets and fairs; several of them were authorized to establish ferries, and New York, Albany, and Philadelphia controlled the local docks and wharves. During the eighteenth century other local needs became pressing in the larger places, and as the charters conferred no authority in these matters, the corporations found it necessary to secure special grants of power, which, however, came now not from the governors, but from the colonial assemblies. Under these statutes, adding to their chartered powers, the more important towns entered upon some new lines of activity : the constructions of drains, the paving of streets, the purchase of fire engines, and toward the end of the colonial period the provision of street lamps and the establishment of a night watch. In Philadelphia 
surveyors for regulating the construction of party walls were authorized as early as 1721 .

These grants from the assemblies to the municipalities, while increasing the actual functions of the latter, tended to change the relative status of the two authorities, making the municipalities subordinate to the assemblies, though as yet it was not recognized that a legislative assembly could pass an act contrary to a charter provision. The prime cause of the change was the fact that the municipal corporations had in no case a charter granting the power of taxation, and when they desired to enter upon undertakings involving taxation, they could not proceed until authority to tax was secured. The colonial legislatures do not seem to have hesitated in granting the desired authority whenever needed, and the local authorities were probably not seriously hampered in their activities by the necessity of securing special grants. By the close of the colonial period all the more important municipalities had received authority to levy certain taxes. But as yet the power was granted only for specific purposes, usually with a strict limitation of the amount of each tax, and often restricting the levy to a certain number of years.

Thus even during the colonial period we may see the beginning of a distinctive American development differentiating the municipalities in the colonies from those of England. Close corporations were the exception; the mayor was already an active official in the city government; central control over the municipalities existed from the first in the governors' power of appointing mayors; while the way was paved for a more active control through the special legislation of the assemblies in. response to the demand of the municipalities for larger powers than those conferred in their charters.

Several urban districts in the colonies remained without the special organization or charter of the English borough. Boston and other New England urban centres found the town-meeting system of the rural communities sufficiently elastic for municipal purposes. Under this system the "freeholders and other inhabitants assembled" in town- 
meeting were not merely electors: they constituted a deliberative body on all questions of town government. They discussed, amended, adopted, or rejected orders and bylaws; they determined the purposes for which public money should be expended, down to the smallest details; and they fixed the exact amount to be raised by taxation. The nearest analogy to a mayor was the moderator of the town-meeting; but his duties were purely those of a presiding officer. The principal administrative work was performed by the prudential or executive committee known as the selectmen; the overseers of the poor, and later the school committee, were also committees of the town-meeting, while there was in addition a goodly number of minor and unsalaried offices.

As Baltimore, Md., and Charleston, S.C., became sufficiently populous to demand special measures, these were decided on by the assemblies of the respective colonies, and carried out by legislative commissions. The Baltimore Board of Town Commissioners, seven persons named by the assembly in $\mathbf{1 7 5 4}$ for life, directed the administrative affairs of that growing port. Possibly this legislative action was preferred to charters of incorporation from a royal governor because of the growing opposition to the latter official in the years preceding the war for independence. It is certainly significant that no municipal charter was issued in any of the colonies after 1746 .

\section{5-1820}

The revolt of the colonies from Great Britain and the new state governments brought about several changes in municipal government. The substitution of elected for appointed governors changed the significance of the appointment of mayors, and in New York State the power of appointment was transferred from the governor to a state executive council; but there was no immediate attempt to transfer the selection of such mayors from the state to a locality.

Of more importance was the change in the charter-granting power. Immediately after the Revolution there appeared a number of municipal charters: in 1783, Charleston, S.C.; 
in 178t, New Haven, Hartford, Middletown, New London, and Norwich, Conn., Newport, R.I. (temporarily), and Nashville, Tenn.; in 1785, Hudson, N.Y. The charters of incorporation for these were not, however, issued by the state governors, but, as was to be the universal rule in the United States, by the state legislatures, in the same manner as statutory acts. By this change these charters could not claim the privileges of a special grant which could not be violated: they were simply legislative statutes, and as such liable to be altered, changed, or revoked by subsequent statutes. There does not seem to have been much discussion on this change in the charter-granting power; the way had been prepared by the frequent additional grants of authority by colonial assemblies to corporations chartered by executive authority; and the tendency of the new state governments was so strongly in favor of the legislature and against the executive, that the new custom was established without question.

The organization and powers provided for in these first legislative charters followed very closely the charters and powers of the existing municipalities, and there are no important developments in municipal organization or functions. It is not surprising to learn that none of the new cities were to be governed by close corporations; and the principle of an elected council was now firmly established as a fundamental rule in American municipal government. Even the close corporations of the colonial days were not permitted to continue. In 1787 the Virginia legislature passed an act declaring that " the former method of electing common councilmen for the borough of Norfolk is judged impolitic and unconstitutional," 1 and providing for election by the freeholders and inhabitants of the borough qualified to vote for burgesses of the assembly. In 1789 Philadelphia received a new charter from the state legislature, which likewise provided for popular election of the municipal council. These statutes are also significant as marking the complete legal supremacy of the legislatures over the municipalities,

1 Hening, Statutes of Virginia, XII, p. 602. 
since not even the existing charters are recognized as barring any measure the legislature might feel disposed to enact. Property rights were, however, retained.

In the closing years of the eighteenth century there was a new series of municipal charters. Schenectady, N.Y., became a city in 1795, Baltimore in 1797, Savannah and Augusta, Ga., in 1798. The Baltimore charter and an amendment to the Philadelphia charter passed in $\mathbf{1 7 9 6}$ mark the introduction of the bicameral system into municipal government. In Philadelphia the legislative power was vested in select and common councils, both elected on general ticket, in neither of which the mayor, recorder, or aldermen found a part. In Baltimore one house of the municipal council was composed of two members from each of the eight wards, elected annually; while the other house was elected by a miniature electoral college, which also elected the mayor, even after this method was abolished for the second council, and the federal government was still further imitated by giving the mayor a veto over the acts of the city council. The parallel was not, however, strictly followed in the matter of appointments; for while the final selection was by the mayor, he was restricted to two candidates for each office, nominated by the council. All of these points mark the beginnings of important developments in American municipal organization.

During the first two decades of the nineteenth century we. find no further important changes in municipal organization. Indeed, during these years, there were but few new municipal charters issued, and so far as these departed from the earlier type, it was by the adoption of some of the innovations already noted. In 1805 the territorial legislature of Louisiana issued to New Orleans a charter of the American type, which replaced the earlier French and Spanish political machinery. This charter provided for a single board of elected aldermen, with a mayor and recorder appointed by the governor of the territory, and in other respects also followed the earlier charters. The first city charter of Detroit, enacted in 1806, but which remained in force only until 1809, contained some of the new features of the Baltimore charter. 
The city council was made bicameral, - each chamber having three members, - and the mayor was given an absolute veto power. But the mayor was to be appointed by the territorial governor, as in New Orleans and most of the important colonial charters, while the mayor was to appoint all the city officers except the register. The first charter of Pittsburg (1816) followed very closely the Philadelphia government as reorganized in 1796 , providing for a bicameral council which elected the mayor.

Up to this time the operations of municipal governments in the United States had undergone no marked transformation from those of the colonial period. With the growth of the larger cities there was of course a gradual increase in the amount of public activity; but this did not mean the assumption of new functions, and even in the largest cities municipal government stood for vastly less than cities of half their population to-day. New York city, which in 1810 had a population of nearly 100,000 , expended in all but $\$ 100,000$; while to-day cities of 100,000 population have an annual expenditure of from $\$ 1,000,000$ to $\$ 2,000,000$. In the country as a whole municipal problems were even less important. As late as 1820 there were but thirteen towns in the United States with over 8000 population, and their combined population was less than 500,000 , barely five per cent of the entire population of the country. Only six cities had over 20,000 population, and these aggregated only 345,000 .

The petty housekeeping of such small urban communities, which in the aggregate composed but an insignificant part of the entire country, could not become a matter of intense public interest. It is not surprising, therefore, that under these circumstances municipal elections should become involved in the more active party struggles of the times. In New York city, at least, the first conflicts on politics, state and national, were mirrored in the local elections. At the same time the spoils system was early established as a principle of municipal office-holding. In the harmonious federalist days Richard Varick had held the office of mayor for twelve years, following the precedent of the colonial times; 
but with the party strifes which set in at the beginning of the new century, the appointment of mayor was considered at Albany as a legitimate spoil, and as often as the political complexion of the state council of appointment changed, New York city had a new executive. From 1801 to 1823 the mayor was changed nine times. The local elections, although held in April, were occasions for bitter contests between the rival parties; frequently almost the entire membership of the council would be changed; and when in 1804 the Democrats first secured control of the council, a caucus of the majority promptly voted "unanimously" to remove all but one of the city officers. ${ }^{1}$

As the net results of municipal development during the first forty years after American independence was accomplished, we find: 1, the disappearance of close corporations and the definite establishment of the principle of locally elected councils; 2 , the supremacy of the state legislatures over municipal charters and the powers of the municipalities; 3, the beginnings of bicameral councils and of the veto power of the mayor; and 4 , the subordination of municipal affairs to the issues of national and state politics.

\section{$1820-1850$}

The new constitution for the state of New York, adopted in 1821, made an important change in municipal government in that state. Heretofore the mayors of New York cities had been appointed by a state authority, following the systems laid down in the first charters of New York and Albany; but henceforth they were to be elective by the common council in each city. This method, as has been noted, was already employed in other American cities, more especially in those incorporated since 1780. But the adoption of this system in the five cities of the now largest state in the Union marks an important step in the transition from state-appointed to locally chosen mayors; and from this time we may date the definitive adoption of the latter as a principle of American municipal government.

1 Durand, Finances of New York City, p. 39. 
Three new municipal charters enacted within the next three years went a step further, and inaugurated the movement for the election of city mayors by popular vote. ${ }^{1}$ These were the first charters of Boston and St. Louis, issued in 1822, and that of Detroit in 1824. In none of these instances did the popularly elected mayor have any materially enlarged powers, either in the way of appointment or of vetoing council ordinances; and in some respects he might have less influence than a mayor chosen by the council, since the latter must have had the confidence of the council to secure his position. But the new method of selection served to give the mayor a more distinct and independent place in the municipal government, and prepared the way for the larger powers to come, when council government became unsatisfactory. It is interesting to note that the second mayor of Boston - Josiah Quincy - did by his personal influence and industry secure the concentration in his own hands of the control and responsibility for the administration of the city ; but this was only a temporary foretaste of the mayor of later times. The principle of electing the mayor by popular vote was, however, quickly apprehended and adopted both in charters for newly created cities and for older municipalities. The mayor of Philadelphia was made elective in 1826, the mayor of Baltimore in 1833, and the mayor of New York in 1834.

Some other features of the charters of Boston, St. Louis, and Detroit should be noted. St. Louis and Detroit had single-chambered councils, in which were vested the powers of the municipality. Boston, on the other hand, adopted the bicameral system, apparently not so much in imitation of the state government as an adaptation of the previous town government - the common council acting as a representative body for the town-meeting, and the mayor and aldermen taking the place of the selectmen. It was probably

${ }^{1}$ In some Connecticut cities before this, mayors were chosen by popular election; but they held office at the pleasure of the General Assembly of the state, which meant practically life positions. Under this rule, New Haven had but four mayors from 1784 to 1826 , two of whom died in office. 
also on account of this development from town government that the mayor and aldermen had no judicial functions as in other municipalities - a rule which has been followed in subsequent Massachusetts charters.

In 1830 a new charter for the city of New York, prepared by a popular convention and ratified by popular vote, went into effect. This separated the council into two branches, "for the same reason which has dictated a similar division of power into two branches, each checking and controlling the other, in our general government." 1 It also gave the veto power to the mayor, and provided that the executive business of the municipality should be performed by separate departments organized and appointed by the council. This last provision proved to be too indefinitely worded to be enforced; and although departments were formally organized, the municipal administration remained as before almost wholly in the control of the council committees. The change to an elective mayor, already noted, was also recommended at this time; but as a constitutional amendment was required for this purpose, the change was not effected until 1834.

The rapid growth of cities as a result of the development in transportation is seen in the record of new municipalities and their charters about this time. Forty of the cities which now have a population of 30,000 or more received their first charter in the two decades from 1830 to 1850 . Nine of these were in New England, where the development of manufacturing centres had increased population beyond the capacity of the town-meeting; five were in New York State; the same number in Ohio; four in Illinois ; and almost every state was represented by one or two cities. With the multiplication of cities at such a rate, it becomes impossible in this outline to note even the most important features of the municipal organization for each, and a few examples must be taken as illustrations of the development at this and subsequent periods. The charters of Cleveland (1836), Chicago (1837), and Milwaukee (1846) may be taken as representatives of the new cities established during the two decades

1 Address of the Convention of 1829. 
before 1850. Each of these charters provided for a mayor elected by popular vote; and that principle may be considered by this time as definitely established in the United States. In Chicago and Milwaukee the council consisted of aldermen only, elected by wards; in Cleveland there were councilmen elected by wards and also aldermen elected on general ticket; but these sat as a single chamber, showing that the bicameral system - although adopted in St. Louis in 1839 - was still the exception in American municipal government. The municipal administration in all of these cases was under the control of the council, which determined the policy of the city, appointed the executive officers, and controlled their action through council committees. It should also be noted that by the close of this period the property qualifications for the municipal suffrage had in most cases disappeared.

The functions of municipal governments had been somewhat enlarged during this period, especially in the larger cities. New York had constructed the Croton aqueduct, the first large municipal undertaking in any country to furnish an abundant water supply. Several cities had established a small and ill-organized body of day police in addition to the night watch. Large volunteer fire companies had been organized in most of the important towns, and were furnished appliances and aided in other ways by the municipal authorities. In some cases, municipal councils now appointed the school boards and poor relief officials; but even in such cases they continued to be regarded as authorities distinct from municipal government.

These additional activities necessarily meant a larger amount of municipal taxation than had existed in the early part of the century ; and the necessity for a regular system of municipal taxation was recognized in most cases by a general grant of the taxing power for any of the enumerated powers of the municipal government, in place of the former system of special authorizations for definite amounts for specified purposes. The general grant was often limited to a certain percentage of the assessed valuation of the city; 
but this limitation was sufficiently flexible to allow for an increase of taxation with the development of the cities, though resort still had to be made to the legislature for further authority whenever a city wished to go beyond the powers enumerated in the charter. For New York city, however, this change to a general authorization was not yet made; each year a special act was passed by the state legislature empowering the city to collect by taxation specified amounts for the appropriations passed by the city council, and although up to this time these annual acts had been largely formal, and passed with little or no change from the bills submitted by the city, the procedure did not give the city full liberty of action.

But even where there was no limitation of the amount of the taxes which a municipality could levy, there was always the restriction that taxation could be used only for the specific purposes enumerated in the charter and special legislative acts. Municipal development along the new lines of activity made necessary by rapid growth was thus often seriously hampered by the need for securing special legislation authorizing the city to undertake additional functions. The system of constantly resorting to the legislature was transferring the real decision on all important questions of municipal policy from the city councils to the state legislatures; while the general tendency of the legislation to enter into minute detail still further reduced the discretionary powers of the local officials, leaving them mainly administrative duties to perform. The extent of this special legislation by the middle of the century may be indicated by the record of the Ohio legislature, which during the session of 1849 to 1850 passed 545 special and local acts.

The main features of municipal development during the period from 1820 to 1850 may be summarized as follows : 1 , the change in the manner of choosing mayors to election by popular vote; 2 , the limited extension of the bicameral system of council organization ; 3 , the general adoption of manhood suffrage; 4 , some expansion of municipal activity ; and 5 , the corresponding development of special legislation. 
By the middle of the century the development of urban communities in the United States had become marked. Within thirty years the population in cities of over 8000 had increased from 500,000 to over $3,000,000$, and the percentage of the total population in such towns, from 4.93 to 12.49. Cities of over 20,000 population had increased in number from six to twenty-nine, and their aggregate population from 345,000 to over $2,000,000$. The more important centres had reached the dimensions of large cities. New York had over 500,000 inhabitants; Philadelphia county over 400,000; while Boston and Baltimore were the centres of urban districts of over 200,000 each.

This expansion of urban population was of its own force making municipal conditions and municipal government a much more important matter in the country than formerly; but beginning about the year 1850 there appeared a decided tendency toward the adoption of new municipal functions, and the rapid development of former activities which still further accentuated the importance of municipal government. Along with this development went changes in municipal organization, and a steady increase in special legislation with significant features, which mark the two decades from 1850 to 1870 as a distinct period in American municipal history.

Of the advance in municipal functions, we may note the organization in New York of the first disciplined police force for any American city in 1845, and the establishment in the same year and in the same city of a paid fire brigade; the construction of the Cochituate water-works for Boston, begun in 1846, and the municipal water supplies of Chicago (1851) and of Baltimore (1854); the establishment of large public parks in New York, Philadelphia, and Baltimore. Similarly, in other important cities, disciplined police forces, paid fire departments, and extensive water-works and sewer systems appeared; while the scope of former municipal activities, such as street paving, schools, and poor relief, was 
rapidly increased, as indicated by the rising tide of expenditures, taxation, and municipal debt. The introduction of street railways and the establishment of large systems of gas supply by private companies also date from this period.

We have already noted slight tendencies toward a change in the position of the mayor in the municipal organization from the earlier colonial period. We have now to observe in comnection with the development of municipal functions, and in complete revisions of several important municipal charters soon after the year 1850 , other more important changes in municipal organization, which decreased the powers of the council, and threw much of the municipal administration into the hands of a series of independent boards. Something in this direction was inevitable with the increase in the mass of municipal work, which made detailed supervision of all by any single authority impossible. Even where the council remained nominally in complete control, the active administration was bound to fall more and more away from the body as a whole to its committees, each of which would become very largely independent. But this inevitable tendency was powerfully strengthened by more direct statutory measures.

In the first place, the special statutes providing for the extension of municipal action entered into greater and still greater detail of means and method, thus depriving the municipal councils of their main functions of a legislative character, and making the state legislatures the real policydetermining power for the cities. This remained the general rule in the face of the first attempts to substitute general for special legislation. In 1851, Ohio and Virginia adopted constitutional provisions forbidding special legislation, and a year later the Ohio Assembly passed the first general Municipal Corporations Act in the United States. But even this act placed Cincinnati in a class by itself; while by imposing strict limitations on the taxing and borrowing powers of the cities, it failed to meet the needs of the growing urban communities. Particular cities demanded additional powers, and these were granted by statutes applying nominally to a 
class of cities, but with the system of classification extended so as to evade the constitutional prohibition. Some other states adopted similar constitutional prohibitions of special legislation: Iowa in 1857, Kansas in 1859, Florida in $\mathbf{1 8 6 5 ,}$ Nebraska in 1867, and Arkansas in 1868. But these were all new states with no large cities.

In the second place, the administration of many municipal functions was conferred by statute on special departments wholly or partly independent of the city council. Previously the school and poor relief authorities had often been more or less independent of the council, and the same position was now given to other branches of municipal work. New York and Cleveland perhaps went farthest in this direction. In New York a new charter issued by the state legislature in 1849 created a dozen executive departments, the heads of which were chosen by popular vote; in Cleveland, under the general law of 1852, the mayor, city marshal, civil engineer, fire engineer, treasurer, auditor, solicitor, police judge, superintendent of markets, the board of waterworks trustees, and three street commissioners were all elected. In Chicago the water board established in 1851 was so thoroughly independent of the council that it had its own borrowing power. Detroit entered on its period of government by independent elective boards in 1857 . The new charters to Philadelphia and Boston in 1854 did not, however, take any aggressive steps in this direction; but they agreed, as well as the other important charters mentioned, in giving to the mayor a limited veto power over council ordinances. A few years later the mayor was given in certain important cities the power of appointing the heads of executive departments, subject to the consent of the council, or of one chamber of a bicameral council. This system was established in Chicago and New York in 1857, and in Baltimore for some offices the year following. The mayor did not have complete control or responsibility under this method; but the change was in the direction of adding to the mayor's power rather than of restoring the former system of council government. 
The precise reasons for the movement away from the council government are not easy to ascertain. The general movement toward democracy and popular election, which was at its height about 1850 , probably was one force leading toward elective officials; the contemporaneous reorganization of municipal functions was rather an opportunity than a cause for the change; yet there could hardly have been such a general movement if council government had been entirely satisfactory. Certainly, after this date, there is much complaint against the councils in the discharge of the powers still in their control. In some cities the principal authority remaining was that of granting franchises and leases and entering into contracts - an authority of no little importance at that period of street railway beginnings and the rapid extension of gas lighting. But in granting such franchises the councils often neglected the interests of the city to an amazing degree, and charges of jobbery and corruption were frequent. In New York four important street railways were chartered in 1851-1852, without limitation as to the duration of the franchise or compensation for the use of the streets. The New York example was generally followed in other cities, except in Baltimore, where the farsighted Mayor Swann, by the hint of his veto power, secured an agreement for the payment to the city of one-fifth of the gross receipts of the street railway chartered in $\mathbf{1 8 6 0 .}$

Beginning about the end of the decade 1850-1860 we find further important measures in the legislative control of several large municipalities, marking in some respects the highest degree of such control. These measures provided for special legislative commissions or boards, appointed by state authority, to conduct certain important branches of municipal administration. The first action of this kind was in New York. In 1856 the legislature when passing the annual tax law for New York city had for the first time made changes in the bill submitted by the municipal authorities. The next year a state park commission for New York city and a state metropolitan police board for New York, Brooklyn, and adjoining counties were established, supplanting 
the city departments; while the control of the courts and judicial administration of New York county (coterminous with the city) was placed in the hands of a board of supervisors, elected by a system which gave the minority party half of the board.

Three years later (1860), the Maryland legislature established a state police board for Baltimore. A year later, the Illinois legislature reorganized the Chicago police force and placed it under a board, the first members of which were appointed by the governor. In 1865 the Detroit police was placed under a state commission ; and the New York legislature added to its former legislation for New York city by placing the fire brigade, health department, and licensing of liquor saloons under state commissions. A similar state commission, which lasted for but two years, was created for Cleveland in 1866. In 1870 the Pennsylvania legislature created a state commission to construct a new city hall for Philadelphia.

In all of these instances the state commissions had not only complete control of the detailed administration, but also determined the general policy to be carried out in their department (so far as the statutes left any room for discretion); and when in New York city the city council attempted to limit their activity by refusing appropriations, the legislature restored the amounts requested by the commissions to the city tax law, and directed the mayor and comptroller to make the payments. So far had legislative action gone that during the late sixties the council of New York city had control over less than one-sixth of the municipal expenditure.

This system of government of municipalities by legislative commissions was enacted on the score of mismanagement and maladministration on the part of the local authorities; and in many cases such charges had no small foundation in fact, so that the situation justified some form of state control. It is by no means so clear, however, that the method of control provided did secure an impartial and effective check on wrongdoing; while it is certain that the prevailing motives for the 
measures taken were too often partisan in character, and that the administration of the state commissions was in consequence directed as much toward securing party advantage as efficient government. The situation in Chicago may be taken as illustrative : In 1861 the Republicans controlled the state government, and the new board of police appointed by the governor was, in consequence, composed of Republicans. In 1863 the Democrats gained control of the state, and passed an act reducing the term of the police commissioners from six to three years, by which action the board became evenly divided between the two parties, while the Democrats hoped ultimately to obtain complete control. But in 1865 the Republicans were again in power in state, city, and county ; and new acts were passed restoring the six-year term to the police commissioners, providing that new commissioners should be elected by the voters of Cook County, - which was less liable to become Democratic than the city of Chicago, and placing the fire department under the control of the board of police.

The real explanation of most of this partisan legislation is found in the continued existence of the spoils system, whereby public administrative offices of all kinds were used as rewards for party workers, and were distributed to strengthen the party rather than to secure efficient administration. With the expansion of municipal activity the number of positions in the large cities available as rewards to the party which controlled the local government was greatly increased; and this made each of the large cities a strategic point, the possession of which was of great importance to the national parties in their struggle for the control of the federal government. This situation was responsible, in large part, for the creation of state commissions and much of the detailed legislation for cities. It was also responsible for the complete subordination of local to national questions in municipal elections, which was made more effective in many cases by making local elections coincident with national elections in November, whereas local elections had, in general, formerly come in the spring months. 
Municipal development, during the period from 1850 to 1870 , is marked by: 1 , the rapid extension of municipal functions; 2, the constant growth of special legislation; 3 , the steady decline of the council; 4 , the tendency toward the disintegration of city government into independent departments, with no unity or harmony of purpose or action; and 5, the growing influence of the spoils system.

\section{$1870-1900$}

Until 1870 the problems of municipal government in the United States seem to have been met in a haphazard way, with no adequate comprehension of the significance or importance of the new conditions produced by the large aggregations of urban population. The years since 1870 are marked by more serious consideration and appreciation of the problems, and by the introduction of beneficial improvements in the municipal system.

Perhaps the heated strife over slavery, the Civil War, and reconstruction had something to do with the extreme partisan measures that have been noted. Certainly, after 1870, there is noticeable a distinct movement against the tide of partisan and special legislation for cities, which may have been due to the calmer tone of national politics, but, on the other hand, may have been simply the inevitable revulsion from the extreme measures of the previous decade. The municipality of New York, which had been legislated into almost nothingness, received a new charter in 1870 , abolishing the state commissions and for the first time giving that city a general power of taxation; and although the immediate effect was to give the Tweed ring in New York free sway for its schemes of plunder, the charter of 1873 made no attempt to revive the state commissions.

The state commissions for other cities were not abolished at this time; but the movement against legislative control of municipalities, in the form of constitutional prohibitions of special municipal legislation, gained ground. Illinois adopted such a provision in 1870, West Virginia in 1872, 
Texas and Pennsylvania in 1873, New Jersey and Missouri in 1875, California and Louisiana in 1879. The amendments to the Missouri and California constitutions allowed the largest cities to frame their own charters ; the amendment to the Louisiana constitution, on the other hand, did not apply to New Orleans. Some other states adopted somewhat different constitutional provisions, aimed more or less definitely at the evils of special legislation.

In Illinois the prohibition of special legislation seems to have affected results, and under the general Municipal Corporation Act of 1872 the detailed organization of the cities in that state was left to the municipal councils. But in other states the various constitutional provisions were not always successful. It was early recognized by the courts that laws applying only to a certain class of cities complied with the requirement for general laws, and such classes were quickly created by statute, each class being under different methods of organization and with different degrees of authority. Notably in Ohio, the scheme of classification was elaborated to such a degree as to pass special legislation for each particular city under the form of laws for a class of cities; and the old system of special statutes for each additional grant of power to a municipality, or even for a change in the detail of executing existing powers, has remained much as before.

The decade 1870-1880 witnessed the reorganization of municipal government in many important cities. The New York charter of 1870 was followed, after the overthrow of the 'Tweed ring, by an amended charter in 1873; and Brooklyn also received a new charter in the latter year. Revised charters were enacted for Richmond in 1872, for Milwaukee and Pittsburg in 1874, and for Springfield, Mass., in 1877 ; Chicago adopted the Illinois General Act in 1875, and in 1876 St. Louis received a new organic law framed (under the constitutional provision) by a city convention, and adopted by popular vote. These charters all agreed in providing for the appointment of many officials by the mayor, subject to the consent of the council. In St. Louis the mayor, who was given a four-year term, had at the beginning of the 
third year of his term the power of appointing the important department heads with the consent of the council.

In several instances the mayor had also the power of removing such officials on definite charges, the mayor of Richmond having this limited power of removal with no power of appointment. In Brooklyn the mayor could suspend, but could not remove, officials; and in New York the mayor could remove only with the approval of the governor of the state. Most of the new charters also agreed in giving to the mayor a limited veto power over council ordinances, subject to a two-thirds or three-fourths vote of the council. These measures were tending to centralize municipal authority in the mayor; but the necessity for securing council confirmation for his appointments, and the restrictions on the removal power, proved to be serious limitations, which left the administrative departments still to a large degree independent, and with no one who could be held directly responsible for mistakes or mismanagement.

By these changes the powers of the councils were becoming of smaller importance than ever. Those of Chicago and other Illinois cities were exceptional in having the power to determine the internal organization of the administration. New York returned to the single-chambered council, and this continued the more general form. St. Louis, however, had a bicameral council, one body chosen on general ticket and one by wards.

Two distinct advances were made in the New York charter of 1873. One was the creation of a board of estimate and apportionment, consisting of the mayor, comptroller, president of the board of aldermen, and president of the department of taxes and assessments. This board had complete control over the preparation of the budgct, and at once became the determining authority in municipal expenditures, and thus the effective centre for the entire municipal government. The second advance was the prohibition on the removal of members of the police force and the fire brigade, except for cause, thus restricting in some degree the operations of the spoils system. 
The census of 1880 demonstrated that 22.5 per cent of the entire population of the United States was in the 286 cities of over 8000 population; that there were 99 cities with over 20,000 inhabitants and with a total population of over $9,000,000$; and that as many as 20 cities had over 100,000 population. The rapid expansion of commerce and industry resulting from the organization of through railroad routes and the development of marine transportation had just begun, and was to continue with unabated force until the end of the century, causing still further development in urban communities.

Municipal functions have developed even more rapidly than urban population during the last twenty years. Not only have police corps, fire brigades, water supplies, and street paving come to be provided in the newer cities, and to be greatly extended in older cities, but new standards of effciency have arisen which have required a development far beyond that accounted for by the growth of population. This development has been most noticeable in respect to fire brigades and street paving. Only ten cities of over 30,000 population in the United States now depend on volunteer companies for fire protection; street paving is now recognized as a necessity not only for the business sections of large cities, but also for the residence localities in even comparatively small communities; and highway construction includes, in addition to streets and small bridges, huge steel and masonry viaducts over broad streams, railroad tracks, and low-lying places, and in recent years underground routes have also become necessary in the largest cities.

In other departments the advance from former standards of municipal activity has been so great as to constitute practically new fields of action. Public education has been entirely reorganized, and elementary schools have been supplemented by tax-supported high schools and free public libraries. Poor relief has been organized and classified and special institutions created for different needs. Extensive public parks are now general in all important 
cities, while the larger places have in addition connecting boulevards and many small parks in the congested districts. Street lighting by electricity, street cleaning, and garbage disposal are important municipal functions almost unknown a quarter of a century ago. 'The supply of light, heat, and power to the community, and the provisions for local transit, have also become questions of intense public interest in cities; and although in most cases the immediate control of these utilities is in the hands of private corporations, there has been public action in the granting of franchises for the use of the streets, while in a few cities municipalities operate gas and electric light works.

This advance in municipal activity has inevitably been accompanied by a corresponding increase in municipal expenditure and taxation, and to such a degree that municipal finances have become of no less significance than the national budget. The total annual expenditure of New York city amounts to over $\$ 100,000,000$, and this sum is equalled by the aggregate expenditures of the seven other cities with over 400,000 population. The smaller cities expend less per capita than the large cities; but their budgets are also for much larger amounts than those of cities of the same population a few decades ago. This expenditure (which is met, for the most part, by the general property tax and special assessments on real estate) and the municipal activities which it represents are made possible by the vast increase in the value of urban property, which has grown even more rapidly than urban population.

Of the recent changes in municipal organization, the most general has been the tendency to concentrate authority and responsibility in the mayor. In 1882 the mayor of Brooklyn was given the absolute power of appointing the principal department heads for that city. Two years later, the same power was given to the mayor of New York city, and by 1890 this principle had been established in Long Island City, Ithaca, Syracuse, and Utica; while in some other cities the mayor had the absolute power of appointment for some positions, though for most, the confirmation of the council was 
necessary. In 1891 the mayor's absolute power of appointment was established in Buffalo; in 1895 in Boston for most of the principal positions; and since then in Lowell, Holyoke, and Quincy (Mass.), the four cities of the second class in New York State, ${ }^{1}$ and other cities. At the same time, however, other recent charters, including those for Philadelphia (1887) and Baltimore (1897), repeat the former requirement that mayors' appointments must secure council confirmation, and this remains the more general rule.

The correlative principle of the mayor's complete power of removing department heads - necessary to establish his full responsibility - has been established in even fewer instances than the absolute power of appointment. In 1895 the mayor of New York was given this removal power for the first six months of his term, the same rule was renewed in the charter of 1897 for the enlarged city, and in 1901 this power was extended over his whole term. The mayor of Boston has, since 1895, had the absolute power of removal, and dating from 1900 the mayors of New York second-class cities have the power of removal for cause specified in the order of removal. Elsewhere the removal of department heads within the term of their appointments can be accomplished only on proven charges of serious maladministration; and there is no effective control over the operations of the various departments except such as may be exercised by party leaders in the interests of the party.

On the other hand, the mayor's veto power is now well established; and by the later charters, the veto may be applied to particular items in an appropriation bill, so that the importance of a measure as a whole need not be the excuse for allowing objectionable items to pass. Generally a two-thirds or three-fourths vote of the council will pass a bill over the mayor's veto; but in Cincinnati and Dubuque a four-fifths vote is required, and in New York city a fivesixths vote.

In the development of systematic financial procedure, also,

1 Rochester, Syracuse, Albany, and Troy. 
the large cities have made noticeable progress. The auditing and accounting department has become almost the centre of the municipal finances; and its head-generally called the Comptroller - is an elective official, even in places where the mayor has the most extended appointing power. In budget procedure the New York idea of a small board of estimate, of which the mayor and comptroller are the leading members, has been extensively imitated. Boston, Baltimore, Buffalo, New Haven, Detroit, Indianapolis, Minneapolis, Sacramento, Superior, Holyoke, Worcester, Saginaw, Cleveland, Columbus, Toledo, and the four New York second-class cities have each some such board, though in a few cases the councils still exercise full power of amending the budget submitted. Chicago, Duluth, Dubuque, Omaha, and Minneapolis are important cities where council committees still determine the budget, often paying scant attention to estimates or recommendations from the administrative officials. In the smaller cities the council remains the central organ in financial as in other municipal business.

The organization of municipal councils remains a matter of discussion and legislation. New York, Detroit, and Cleveland, after a brief period of bicameral councils, have returned to the single-chamber system ; but Boston, Philadelphia, and Baltimore retain the double house. The importance of the council has steadily diminished, not only through the growth of the mayor's power and that of the department heads, but also in some states through special legislation conferring local franchises, thus depriving the council of the sole remaining function of real significance. But whether granted by council or legislature, franchises have continued to be granted with little or no comprehension of their value. The grants have been for long terms, sometimes in perpetuity, and the provisions for compensation have been both vague and inadequate. The New York charter of 1897 limits the duration of any franchise grant to twenty-five years.

Expansion of municipal functions and municipal expenditure has involved a corresponding expansion in the administrative service, positions in which have continued to be 
filled often for party purposes rather than for the most efficient service to the city. So long as one party remained in power for some time, the administrative results were perhaps tolerable, and the principal evil of the system was that it enabled the party machine in control to intrench itself, so as to make its defeat almorst impossible. But when, either through local contests or the perturbations of national and state politics, frequent changes occurred in the party control of a given city, the no less frequent changes in the administrative subordinates, substituting new men for those of at least some experience, involved serious delays and mistakes in municipal work, and produced most inefficient results and intolerable conditions.

The law of 1873 of New York city, prohibiting the removal of certain subordinate officials, except for cause (for example, members of the police force and fire department), was the first important measure to counteract this tendency, and this rule has since been adopted in other cities. Soon after the adoption of the competitive examination system for the national civil service, a similar system was provided for Philadelphia and the cities of New York State and Massachusetts. In New York the civil service rules of the various cities must be approved by the state Civil Service Commission; while in Massachusetts they are drawn up by that body. In 1894 Chicago adopted a like system, and the New Orleans charter of 1896 followed these examples. A few other cities have civil service examinations, but in most cases there is much need for improvement in the method of selecting municipal employees.

Further constitutional prohibitions of special legislation appeared during these two decades: for the new states of North Dakota and South Dakota, Wyoming, and Washington in 1889, for Mississippi in 1890, and for Kentucky, Minnesota, and Wisconsin in 1892. The Washington constitution and a constitutional amendment for Minnesota in 1896 followed Missouri and California in giving the large cities the right to frame their own charters within the limits set by general statute. But as was already apparent in the state which had 
adopted such provisions earlier, the difficulties of defining a special act, and of distinguishing municipal affairs (for which special legislation was forbidden) and other matters on which there was no restriction, have resulted, in many states, in the practical nullification of the prohibition.

The New York constitution of 1894 contains no prohibition of special legislation, but does contain a provision that special city laws (which are defined as laws applying to less than all the cities in any one of the three classes defined in the constitution) shall be submitted for approval by the city concerned, and any bill disapproved by it must be repassed by the legislature and signed by the governor to become a law. This provision at least prevents special legislation from being enacted without giving the local authorities an opportunity to present their protest if opposed; it may also prove competent to prevent the passage of some measures over the local veto; but it can hardly accomplish any result in the case of a party measure supported by the party in control of the legislature and opposed by the party in control of the city.

Special state commissions to administer certain functions generally in the control of the municipal authorities have been established within recent years. The Detroit police commission became a municipal board in 1891; but the Baltimore commission has continued as a state board since 1860 . St. Louis has had a state police board since 1861, Boston since 1885, Cincinnati since 1886, and similar state commissions now exist elsewhere. In San Francisco, Denver, Fall River, Kansas City and St. Joseph, Mo., Birmingham, Ala., Manchester and Concord, N.H., and in eleven Indiana cities, such commissions may be found. Omaha had one for ten years (1887-1897) subject to frequent partisan legislation which recalls the Chicago police statutes of 1860-1865. Elsewhere, the desire for patronage seems to have played a less important part in the movement than it did three decades ago, and the principal motive seems to have been to insure a more vigorous enforcement of legislation restricting or prohibiting the liquor traffic. It is doubtful, however, if this result has been accomplished to any extent, for in the long 
run the state boards have generally found it advisable to recognize the local sentiment which affected the former local boards, and the principal outcome of the legislation has been to strengthen the political influence of the party managers controlling the state governments. A more effective course for administrative improvement would seem to be the application of the principle already recognized in health, education, and charity administration, the establishment of a central state authority with power to investigate the work of local authorities, and to compel the latter to enforce the law when they have been proven delinquent.

Some steps have been taken to diminish the influence of national and state politics in local elections by arranging the municipal elections at different times from the general elections. The Massachusetts cities have their elections in December, a month or more after the general elections; New York has its municipal elections in the odd years, when there are no congressional or presidental elections; but as there are annual elections for the state legislature, there is not yet a complete separation here. Some cities, including all in Illinois, hold municipal elections in the spring, as is the general rule for elections in rural towns.

The census returns for 1900 show the urban movement of population still in force, although at a somewhat diminished rate for the last decade. Since 1880 the number of cities in the United States with over 8000 inhabitants has nearly doubled; the aggregate population in this class of cities has more than doubled; and the percentage of total population in such cities has increased from 22.6 to 33.1. There are now 545 places in this class with an aggregate population of 25,000,000. Cities of over 25,000 inhabitants number 159, aggregating a population of 19,757,000. Thirty-eight cities have each over 100,000, with a total of 14,208,000. In each of these classes the aggregate population now exceeds that of the corresponding class in the United Kingdom; but the latter has still the greater proportion of urban population.

New York city with 3,437,000 inhabitants in its extended boundaries is easily the second largest city in the world. 
Chicato $(1,698,000)$, the second American city, is surpassed in Europe only by London, Paris, and Berlin; while Philadelphia $(1,293,000)$ needs to add only Vienna to the list. Boston, with a municipal population of 560,000 , is, like Manchester in England, but part of an urban community of over a million. St. Louis and Baltimore have each over half a million; and other cities are not far behind.

We have noted the growth of urban population and the development of city government in the United States from the petty colonial boroughs of the seventeenth and eighteenth centuries to the vast metropolitan municipalities of to-day. We have seen the evolution from the simple and unorganized council government to the complicated administrative machinery of municipal departments. In the process the central direction of municipal affairs has passed from the council, and in most American cities authority is distributed and dissipated on no fixed principle among council, mayor, and state legislature; while the influence of national and state political contests in municipal elections, and the operation of the spoils system in municipal office-holding, have served to deteriorate still further municipal administration. In recent years, however, we see certain tendencies toward a more scientific distribution of authority, toward the separation of municipal from national and state elections, and toward a more efficient and permanent subordinate service; $;$ and although these tendencies have not as yet become widespread, yet it is along the lines already indicated that further advances of a permanent nature may be most rationally anticipated. 


\section{CHAPTER VI}

\section{French Municipal History since 1789}

Authorities. - Dalloz : Jurisprudence Générale.-Pizard : La France en 1789. - Hélie : Les Constitutions de la France.-Monnet : Histoire de l'administration française. - Cobden Club Essays on Local Government. - Albert Shaw : Municipal Government in Continental Europe, ch. 2.

IN the reorganization of France by the Constituent Assembly, in 1789 , the provinces and their subdivisions made way for departments and districts, in the formation of which the old lines of demarcation were purposely avoided; but the forty thousand communes, spread like a network over the land, remained unaltered, as the fundamental unit of the new political structure. On the other hand, if territorial revision was not attempted, there was, in $\mathbf{1 7 8 9}$, a complete reorganization in the method of governing the communes, and since that date municipal institutions in France have been a constant subject of legislation. Each of the many governments which have ruled France during the last century have, in turn, passed laws on communal government, stamped with its characteristic political ideas.

Although central control over municipal government had been thoroughly established under the old régime, there was nothing like uniformity either in the organization of the communes or in their financial obligations to the royal treasury. As for the organization, a rough classification may be made, but always with the reservation understood that there were innumerable exceptions. In general, then, it may be said that before the Revolution:-

1. In towns of over 4500 population there was a mayor, four echevins, six, eight, or ten councillors, a syndicreceiver, a secretary or clerk, and a public prosecutor (procureur-du-roi). 
2. In towns with a population between 2000 and 4500 , a mayor, two echevins (or assistants), four councillors, a syndic-receiver, and a clerk.

3. In towns with less than 2000 population, there was no mayor, only two echevins, three councillors, a syndic-receiver, and a clerk. ${ }^{1}$

From the financial point of view three special classes of communes may be noted, in addition to those which paid the general fiscal charges and no more:-

1. Those towns subject to additional royal imposts over and above the general taxes.

2. Those towns which, by virtue of old privileges, were exempt from the imposts.

3. Those towns which, by a lump payment, had purchased exemption from certain royal charges.

On every page of the cahiers of 1789 appeared the demand for the renewal of the old communal rights, especially for that of choosing their own officers, ${ }^{2}$ and for abolishing all discriminations. The reform of local administration was, in fact, the most pressing question before the Constituent Assembly; and the subject was considered immediately after the constitutional law organizing the central organs of government, ${ }^{3}$ although, with characteristic French method, the Declaration of the Rights of Man had been considered and decided on before either.

The law on municipalities was reported to the Assembly on September 29, and passed December 14, 1789. This law made three sweeping changes in the municipal administration. First, all the existing municipalities, whether under the title of "hotels de ville, mairies, echevinats, consulats," 4 or any other name, with their intricate and anomalous powers, were abolished; and in their stead a strictly uniform system was established for all France - uniform both in organization and in financial relations to the central government.

1 Pizard, La France en 1789, p. 194.

2 Dreyfus, Manuel Populaire de Conseiller Municipale, p. xxi.

${ }^{3}$ Hélie, Les Constitutions de la France, p. 59.

4 Article 1, Law of 1789 (December 14). 
Second, local self-government was inaugurated by making the municipal officers elective, ${ }^{1}$ the suffrage extending to all but the poorest class. Third, the system of central control was completely abolished, and each commune became practically an independent republic. Each commune was to be provided with a municipal corps, composed of a mayor (maire), with several other executive officers. There was also to be a number of notables, double in number to the municipal corps; and the two classes formed the council general of the commune, a deliberating body, which met to decide important matters.

Ordinary municipal administration was carried on by the municipal corps alone, which, in turn, divided itself into two bodies. One-third of its members, including the mayor, formed an executive bureau; the remaining two-thirds formed the municipal council, which met alone to examine the accounts of the bureau, and met with the bureau to discuss all other municipal business. Members of the municipal corps and notables were elected one-half each year, for a term of two years.

In order to adjust this system to both large and small communes, the number of officials was to vary with the population. Communes having less than 500 population had a municipal corps of three members; the number increased with the size of the towns by a sliding scale, cities of over 100,000 having the maximum number of twenty-one.

The municipal officials, in addition to their purely local functions, such as administrating the communal finances, directing and executing local public works, also acted as agents of the central administration. In this capacity they were charged with the assessment of the commune's share of the direct taxes, the collection and transfer of the same to the departmental treasury, and the immediate direction of national public works or property in their municipality. In all of these affairs the communal officers were subject to no supervision or control by the central government.

This scheme of municipal government established by the

1 Articles 2, 5, Law of 1789. 
law of 1789 proved to have two serious defects. It took for granted a practical knowledge and habit of local self-government which the French people entirely lacked, and without which the system of local independence proved entirely impracticable; and in attempting to avoid the confusion and lack of system of the old régime, a system was adopted which proved too cumbrous and elaborate for the small rural communes. ${ }^{1}$

The constitution of the Directory (1795) provided a new system of municipal government, ${ }^{2}$ which recognized these defects. Under this system communes of less than .5000 population were no longer to have a full municipal organization. Each such commune should have a municipal agent and an assistant, who had charge of all the active administration in the commune; but the real municipal unit was the canton, a new territorial division, which included, on the average, about twelve communes. The municipal administration of each canton was in charge of a council composed of the agents of the communes in the canton, together with a president elected by the canton. The small communes were thus absorbed by the canton, becoming little more than administrative divisions of that circumscription. This system has been aptly compared to the township-county system of rural local government in such states as New York and Michigan.

Communes with a population between 5000 and 100,000, under the law of 1795, formed each a distinct canton, under an administrative council of from five to nine members. The cities of over 100,000 inhabitants (Paris, Lyons, and Marseilles) were partitioned into several municipalities, ${ }^{3}$ each of which had a council of seven members, elected for two years, as nearly one-half as possible retiring each year. In each of these cities there was also a central bureau of three members appointed, in Lyons and Marseilles, by the authorities of the department, subject, however, to confirmation

1 Shaw, Municipal Government in Continental Europe, pp. 149, 150.

2 Constitution, 5 Fructidor, An. III ; Title, III.

8 Paris was divided into twelve, Lyons and Marseilles each into three. 
by the Directory, and in Paris appointed directly by the Directory.

A serious limitation upon the independence of the municipalities, and an important step in reëstablishing the system of central control, was also introduced at this time, by giving the departmental administration the right to nullify the acts of the cantons and municipalities, and also, under certain circumstances, to suspend the municipal officers, subject, however, to the approval of the central government at Paris.

The recentralization of the administration by the Directory was completed under Napoleon, as First Consul, in 1800. The law of 28th Pluviose, in the Year VIII, ${ }^{1}$ with its system of prefects and sub-prefects in all the departments, each official appointed by a superior and responsible only to the central authority, recalls vividly the old monarchical system and the régime of the intendants. In the municipal organization, also, important changes were made. The cantonal municipalities of the previous constitution were abolished, the cantons themselves disappeared as administrative units (though still remaining for judicial and election purposes), by the reëstablishment of the district, under the new name of "arrondissement." In every commune there was established, as in the law of 1789 , a municipal council, with a mayor and one or more adjoints; but the system of local election was abolished, and these all became appointive officials. In towns of 5000 population and over the mayor and adjoints were appointed by the First Consul, while the councillors in these towns, and all the officials of the smaller communes, were to be appointed by the departmental prefects. Two or three years later the electors of the municipalities were permitted, under some circumstances, to nominate the candidates for every place which became vacant, one of whom should be appointed; but even this concession was not allowed to become operative as a general rule. ${ }^{2}$

At the beginning of the nineteenth century, when this 1 Hẻlie, p. 611.

Shaw, Municipal Government in Continental Europe, p. 157. 
system went into effect, France had already been slightly surpassed in urban development by the British Isles. With almost double the total population, France had but 1,840,000 inhabitants in cities of over 20,000 population each as compared with over 2,000,000 inhabitants in cities of that size in Great Britain and Ireland. London and Dublin combined had over 1,000,000, while Paris, Lyons, and Marseilles aggregated 767,000 .

The administrative organization of Napoleon has remained intact to the present day, so far as the territorial divisions and the titles of the various officials are concerned. The method of appointing all the local officials also remained in force for thirty years. No change was made at the time of the Restoration of the monarchy in 1815; and not until after the Revolution of 1830 was a substantial concession to the principle of local self-government made. By the Act of March, 1831, the municipal councillors (but not the mayors and adjoints) were chosen by electoral assemblies, to which were admitted: 1 , a certain proportion of the largest taxpayers, the exact ratio varying with the population of the communes; 2, the professional, official, and educated classes, and all persons qualified to vote for members of the Chamber of Deputies or for the departmental councils. ${ }^{1}$ Two-thirds of the councillors must be elected from the first class of electors.

In the smaller communes, where the number of electors in the first class was equal to one-tenth of the population, the requirements for voters were, in the main, a modest property qualification; but in the large towns, where the number of electors included in the first class was (in towns of over 15,000 population) but three in each hundred of the population, the limitation on the suffrage was much greater. The franchise for the parliamentary elections at this time included but 200,000 electors for the whole of France, with a population of $30,000,000,{ }^{2}$ so the addition to the electoral assemblies on that score could be but slight. The mayors and

1 Law of 1831, article 2; Dalloz, Jurisprudence Générale.

2 Annual Register, 1831, p. 342. 
adjoints continued to be appointed by the king or the prefects, but the selection had to be made from the elected members of the municipal councils. ${ }^{1}$ The supervision and control of the prefect over the communes and their affairs continued in undiminished force for several years. The law of July 6, 1837, on the "attributions" of the municipal officers, however, gave the municipal councils (1) the right of refusing to act on matters concerning local affairs; and (2) the right of initiative; but positive action still required the authorization of the central government. ${ }^{2}$

This legislation of 1831 and 1837 was a decided advance toward decentralization in municipal administration. The constitution and legislation of 1848 continued the process. The constitution laid down the principle that all the citizens should have a vote in the election of municipal councils ${ }^{3}$ and universal suffrage was carried into effect by the law of December 10, 1848, which also permitted the councils, in towns of less than 6000 inhabitants, to choose their own mayors and executive adjoints. For towns of over 6000 , the provisions of the law of 1831 , in respect to the appointment of mayors and adjoints, still prevailed.

The coup d'etat of 1852 interrupted the process of decentralization in France. The law of July 7, 1852, placed the municipal functions once more in the hands of the central government. ${ }^{4}$ The municipal councils were allowed to remain elective; but the executive officials were all appointed, and the choice was no longer limited to the members of the councils, as under the law of 1831. The practical initiative was in the hands of these appointed officials, and the elective councils were expected to approve the projects and budgets presented.

In the law of July $24,1867,{ }^{5}$ the Second Empire enlarged the powers of the municipal councils, granting them the right of acting in certain important matters, which had hitherto been under the control of the central administration.

1 Article 3, Law of 1831.

2 Ducrocq, Droit Administratif, I, 378-379.

4 Dalloz, 1884, p. 26.

8 Articles 76, 79, Constitution of 1848.

5 Hélie, p. 1299. 
But the same law gave the prefect authority to suspend a municipal council and replace it by an appointed commission, which could remain in power for three years.

The growth of cities in France during the first half of the century had been at a much slower rate than in Great Britain, or even in Germany; yet urban population had doubled, while the total population had increased but onethird. In 1851 there were 5 cities with over 100,000 , and 63 cities with over 20,000 , the population of the latter class aggregating $3,810,000$.

Up to this time no important developments had appeared in the field of municipal activities; but under the centralized system of the Second Empire the physical betterment of the larger cities was begun and prosecuted with vigor. In Paris, under Baron Haussman, prefect of the Seine, the work was executed regardless of expense and with imperial scope and magnificence. In the central congested districts thousands of houses were cleared away for a radical reconstruction of streets and squares; in the outlying districts, broad boulevards, open squares, parks, and pleasure grounds were laid out; and for the whole city a comprehensive sewer system and new water supply were furnished. In the important provincial cities other energetic agents of Napoleon III carried out smaller schemes, and the period from 1852 to 1870 is one of marked material progress in the chief communities of France.

One of the first acts of the National Assembly under the Third Republic was to revive the law of 1848, giving communes the right of choosing their own municipal executive officers. The bill as introduced made the same reservation as did the law of 1848 , - that in towns of over 6000 these officials should continue to be appointed; in the Assembly an amendment was carried (by a vote of 285 to 275), abolishing this distinction. President Thiers feared to try this experiment; and it must be remembered that, except for the ten years between 1790 and 1800, the executive officials of all the large towns of France had been directly controlled by the central authorities. Thiers protested against what 
seemed to him a rash step, threatening to resign if the amendment was insisted on; and his efforts were finally successful in procuring a provision that in towns of 20,000 population and over, and in the chief town in each department and arrondissement, the mayor and adjoints should continue to be appointed. ${ }^{1}$

Even with the amendment, the new law allowed municipal autonomy to a larger degree than the law of 1848; but in 1874, after MacMahon had been made president, a reactionary law was passed, ${ }^{2}$ restoring the legislation of the Second Empire. All mayors and adjoints were made appointive by the ministers or prefects, and, under certain conditions, they could be chosen from outside the members of the municipal councils. This law had been passed for the benefit of. the monarchical parties in France, and the 37,000 places put at the disposal of the government were rapidly filled by Legitimists, Orleanists, and even Imperialists. In spite of these efforts the election of February, 1876, put the Republicans in control of the chambers, and their first care was to repeal the law of 1874 on municipal government. By the law of August $12^{3}$ the law of 1871 was practically restored, the only change was that the provision for appointing the municipal executive officers in towns of over 20,000 population was replaced by a provision making them appointive in the chief town in each canton. Moreover, even in the towns where the mayor continued to be appointive nominally, the substance of power was now in the hands of the locally elected councils. Extreme centralization was found in practice to be impossible in a republic, the municipal councils became more and more assertive, while the prefects and central government became correspondingly more compliant. ${ }^{4}$ At length, in $1882,{ }^{5}$ the provision for the appointment of mayors and adjoints in the chief town in each department,

${ }^{1}$ Monnet, Histoire de l'Administration, ch. 10 ; Law of April 10, 1871.

2 Law of January 20, 1874.

8 Dalloz, Jurisprudence Générale, 1871.

- Shaw, Continental Europe, p. 161.

${ }^{6}$ Law of March 28, 1882. 
arrondissement, and canton was repealed, and these officers became elective in every commune in France. Paris, however, was excepted from this rule, and has been the subject of special legislation, placing its municipal affairs very largely under the direct control of the central government. The two principal officials are the Prefect of the Seine and the Prefect of Police, both appointed by the minister of the interior. There are also an elected municipal council and twenty maires, one for each arrondissement into which the city is divided.

The need of codifying existing enactments on the subject of municipal government had been recognized since the formation of the Third Republic. It was also felt that further decentralization in the management of local affairs was advisable; that the decisions of the municipal councils should be released from the requirement of central administrative approval. ${ }^{1}$ Accordingly, in 1884, the loi sur l'organisation municipale was enacted ${ }^{2}$ this made some important changes in the law on the subject, and consolidated all the provisions for the organization and government of communes into a systematic code - the basis of the present municipal system in France.

An additional piece of legislation of considerable importance is the law of March 22, 1890, ${ }^{3}$ which provides for the association of adjacent communes for the purpose of carrying on works of intercommunal utility. For the management of such works a committee of two delegates from the municipal council of each commune in the association or syndicate is to be elected, this committee to have full control. This legislation provides a method for securing adequate local administration in the small rural communes in such matters as poor relief, hospitals, secondary and technical schools, without resorting to the cumbrous method of the cantonal municipalities of 1795-1800.

During the last half of the nineteenth century the population of France has remained almost stationary, and very

1 Goodnow, Administrative Law, I, 287.

8 Dalloz, 1890, IV.

2 Law of April 5, 1884 ; Dalloz, 1884, IV, 25. 
largely on this account the increase in urban population has been less marked than in other countries. Nevertheless, since 1850, there has been a most decided growth in the city population, all the more noticeable in view of the stationary state of population in the country as a whole. From 1851 to 1896 the population of the present territory of France increased from $34,901,938$ to $38,517,975$. In the same period the aggregate population of cities with over 20,000 inhabitants showed an increase from $3,811,500$ to over $8,000,000$. Cities of over 100,000 population increased in number from 5 to 12 , and the aggregate population of such cities from $1,656,900$ to $4,793,491$. Paris, with 2,511,000 inhabitants, ranks next to London and New York among the largest cities in civilized countries. The next largest cities in France, Lyons and Marseilles, are each under half a million population; and two other cities, Bordeaux and Lille, have each over 200,000 .

"The advocate of direct municipal ownership and operation, of such supply services as lighting or transit, will not find it advantageous to visit the French towns. He will find in them very few important experiments in this direction, and will conclude that Great Britain and Germany are the fields best worthy his attention. . . . The chief French provincial towns, if one may generalize sweepingly, have, indeed, much more to show the visitor who is attracted by imposing boulevards, by elegance in public architecture, by well-kept parks and squares, by interesting and artistic monuments, and by the other externals of municipal aggrandizement, than they can reveal to the inquirer who cares most for the achievements of sanitary science and for kindred social services. In this regard they have much to learn from the large British towns, which, while less attractive in many of their external appointments, have, as a rule, accomplished far better results in the provision of pure water and wholesome drainage, in housing reforms, and in aggressive sanitary and social administration along various lines." 1

${ }^{1}$ Shaw, Municipal Government in Continental Europe, pp. 187-191. 


\section{CHAPTER VII}

\section{German Cities during the Nineteenth Century}

Authorities.-Bornhak : Preussisches Verwaltungsrecht. - Leidig : Preussisches Stadtrecht. - Stengel : Organisation der Preussischen Verwaltung. - Block : Dictionnaire de l'Administration Française.

Next to Great Britain and the United States the most important country in urban development is Germany. But while the urban movement in that country has become marked only since the middle of the nineteenth century, the basis of the municipal organization was laid almost at the beginning of the century, in the Prussian Municipal Corporations Act of 1808 , the work of the famous Baron von Stein.

During the eighteenth century the subjection of German cities to the various state governments had been steadily emphasized, and at the same time the character of the municipal government had greatly deteriorated. The condition of the Prussian cities before Stein's reform applies, also, to the cities in other German states. The magistrates in some places were selected by coöptation, but for the most part they were appointed directly by the government, and the citizens had little or no influence in the administration. The city offices were often filled by invalided soldiers, appointed without regard for their competence, apparently as a system of military pensions. Moreover, the local officials were under a strict tutelage, exercised by state officials known as tax commissioners, each of whom had charge of a considerable district, while the taxes collected for local purposes were insignificant in comparison with those paid to the state.

The first measures of reorganization were made in the western parts of Germany, under the influence of the French Empire; and the French centralized system, with appointed executive officials under a rigid central control and elected 
councils having no authority, was introduced. The system established in Prussia in 1808 occupied a middle ground between the centralized system and the system of complete local independence, which had been tried in France, in 1790, and failed. The central point in Stein's organization was the council, elected by the burghers, who included all those who owned land or carried on a trade in the city. The members of the council were chosen for three years, onethird retiring each year. The particular functions of the council were to control local taxation and to select the executive officials. The latter consisted of a paid burgomaster and both paid and unpaid magistrates, some chosen on account of special knowledge, serving for twelve years, the others for six years, one-half retiring every three years. The persons elected by the council were subject to confirmation by the agent of the government in the province; in cities of over 10,000 the burgomaster was, appointed by the king from a list of three names presented by the council. Office-holding was made compulsory, and even the electors were required to vote on pain of losing their rights. These municipal officials could act on their own motion on all matters relating to municipal property, or the economic welfare of the town, subject to a limited state oversight, exercised by examining accounts, hearing complaints, ratifying new ordinances, and sanctioning appointments. The former judicial system in the towns was, however, replaced by a system of state officials; the police might be under state officials, or under the local officials, subject to active state control.

This Act of 1808 applied only to the provinces then included in Prussia: East Prussia, West Prussia, Brandenburg, Pomerania, and Silesia; and in 1815 it was not extended to the districts regained or newly added to Prussia. Here the municipal government remained for a time under the new French or earlier German methods.

In 1831 a revised Municipal Corporations Act was enacted for the cities in the eastern provinces not included under the Act of 1808, and later extended to Westphalia (1835), Posen (1841), to single Rhine cities, and, in 1845 , to the 
Rhine province. Cities organized under the Act of 1808 were allowed to substitute the Act of 1831, but few acted on this permission. The Act of 1831 was drawn on the same general lines as that of 1808, but with some important modifications limiting the scope of municipal autonomy.

All persons owning real property of a certain value (3001200 thalers) must become burghers; others, with an income of 200 thalers and two years' residence, were permitted to become burghers. This was an extension of the franchise to owners of personal property. The number of members in councils varied from nine to sixty, a reduction from the numbers in the Act of 1808; elections might be either by gilds or wards; in elections by wards a minimum property qualification in land or income was required for members of the council. Burgomasters might be chosen for life if the council, magistrates, and government consented. Provision was made for differences between the council and magistrates, and if no agreement was possible, the government was to make the decision. The system of oversight by the central government was somewhat stronger than under the Act of 1808.

After the Prussian constitution of 1848 was put into force, an attempt was made in an act of 1850 to establish a uniform municipal system for both cities and rural villages, such as existed in France. This law was based on the existing Prussian city government, and resembled most nearly the organization in the Rhenish districts which had been subjected to French influence. But the differences between city and country imposed obstacles to the working of a uniform system, the law of 1850 was suspended, and Prussia returned to the method of statutes dealing only with the government of cities. New Municipal Corporations Acts were enacted in $\mathbf{1 8 5 3}$ for the six eastern provinces, and in $\mathbf{1 8 5 6}$ for Westphalia and the Rhine province. These acts followed the main features of the Act of 1808 and 1831. The principal new features were the extension of the municipal franchise and the introduction of the three-class system of voting. According to this system, the electors were grouped into three 
classes: those taxpayers assessed for the highest amounts, who paid together one-third of the direct urban taxes, formed the first class; a larger body of middle-class taxpayers, contributing together another third of the municipal taxes, formed the second class; the small taxpayers, paying the last third, formed the third class. Each class elected onethird of the members of the council by an open vote. The only important variation in municipal organization under the various acts was that in the Rhine province the executive magistrates were not elected by the council as a separate authority, but were made appointive and subordinate to the burgomasters, in the same relation as the adjoints bore to the maires in French communes.

In the kingdom of Hanover a general Municipal Corporations Act was put into force in 1851, and a revised statute in 1858. Both of these laws followed very closely the existing laws in Prussia. There was, therefore, no necessity for any important change when Hanover was annexed to Prussia in 1866. For the other additions to Prussia at this period the municipal arrangements of the Act of 1853 were, with slight variations, extended to Frankfort-on-the-Main in 1867, to Schleswig-Holstein in 1869, and to the former Duchy of Lauenberg in 1870.

The law on the jurisdiction of the administrative courts, enacted in 1883, formed a supplement to the general municipal law, regulating both the competence of the municipal officials and the state organs of supervision. This state supervision is exercised especially with reference to the amount of local taxes and the making of loans, and in the administration of the police, where that is in the hands of the municipal authorities.

Cities in Bavaria are now organized under a law of 1869 , and the cities in Saxony under a law of 1873. These laws, and those in other German states, in their main features closely resemble the Prussian legislation, with the exception that the three-class system of voting is not employed.

This legislation, providing the framework of municipal 
government, was enacted before the day of large cities in Germany, and it is a significant contrast with conditions in the United States that the system adopted for small cities has proven adequate to the large urban communities which have developed, especially during the last three decades.

At the beginning of the century Berlin and Hamburg, alone of the cities in the present German Empire, had over 100,000. Even cities of over 20,000 population were less frequent than in France and much less so than in the British Isles; the population of those in Prussia, Saxony, and Bavaria aggregated less than 900,000 in a total population of $15,000,000$. By the middle of the century there were four cities with over 100,000 population, - Berlin, Hamburg, Breslau, and Munich, - and the population of cities of over 20,000 in the three principal kingdoms aggregated 2,784,000. At this time urban development in Germany was no further advanced than in the United States, and was still behind that in France.

During the next two decades a considerable further development in urban population appeared. Dresden, Cologne, Königsberg, Leipzig, and Magdeburg came into the class of cities with over 100,000 ; Berlin by 1871 had 825,000 population; and by that year there were in all 28 cities with over 50,000 inhabitants. But the most striking development has been since 1871, in connection with marvellous advance in commercial and industrial life which has followed the creation of the German Empire. In 1900 there were 33 cities with over 100,000 population, aggregating $9,100,000$ inhabitants, in a total population of $56,345,000$. The cities of over 20,000 in Prussia have almost 9,000,000, in a total population of $34,468,000$. Berlin has $1,888,000$, Hamburg 705,000, Munich 500,000, Leipzig 455,000, and Dresden 422,000.1 During these three decades the city population of Germany has far outstripped that of France; and the ratio of growth, though not the absolute increase, has been higher than that in the British Isles. Both in ratio and absolute numbers, however, Germany has been

${ }^{1}$ Zeitschrift des Königlich. Preuss. Stat. Bureaus, 1901, p. 39. 
exceeded by the United States, ${ }^{1}$ which ranks second to the United Kingdom in urban development.

This recent municipal movement in Germany is characterized by three distinguishing features, which need now be but briefly noted. The government of the cities is not on a democratic basis, as in the other important urban countries, but continues to be controlled by the wealthier classes in each community. The active management of municipal affairs is very largely in the hands of a special class of technically trained officials, who apply scientific administrative methods to a degree unknown in other countries. Yet it is these cities which have advanced farthest in the direction of what is known as "municipal socialism"; not, however, as the result of any political propaganda, but as a gradual development from their own experience.

"In Germany the community organized centrally and officially is a far more positive factor in the life of the family or the individual than in America. The German municipal government is not a thing apart, but is vitally identified with every concern of the municipality, and the municipality is the aggregation of human beings and human interests included within the territorial boundaries that fix the community's area and jurisdiction. There are in the German conception of city government no limits whatever to the municipal functions. . . The German city holds itself responsible for the education of all, for the provision of amusement and the means of recreation, for the adaptation of the training of the young to the necessities of gaining a livelihood; for the health of families; for the moral interests

1 Mr. Albert Shaw, Continental Europe, ch. 5, argues that the growth of cities in Germany has been no less, and perhaps more marked, than in the United States; but the evidence is not entirely convincing. In comparing particular cities, he neglects to include populations which form parts of the urban communities, although not within the legal boundaries, of American cities, such as New York, Boston, and Pittsburg. If the figures for the urban communities are compared, it will be seen that, even in recent years, the American cities have grown more rapidly than those of Germany; while the aggregate city population in the two countries shows still more clearly the same result. 
of all; for the civilizing of the people; for the promotion of individual thrift; for protection from various misfortunes; for the development of advantages and opportunities in order to promote the industrial and commercial well-being, and incidentally for the supply of common services and the introduction of conveniences." 1

Two further characteristics of the entire Prussian system of local administration which necessarily attach to the municipal government may also be mentioned. In the first place, there is a large amount of obligatory and unpaid service required from the well-to-do citizens, a feature consciously adopted as a counterbalance to the bureaucratic tendencies of the permanent professional officials. In the second place, the local authorities are not dependent on special legislative grants of enumerated powers, but, as in France, have a general grant of power; while the necessary control of the central government is exercised, not by a legislative body ruled by partisan political motives, but by administrative and judicial officers whose actions are determined by fixed rules and the interests of the community. ${ }^{2}$

1 Shaw, Continental Europe, pp. 323, 329.

2 F. J. Goodnow, Comparative Administrative Lav, I, 336. 
STATISTICS OF URBAN POPULATION

Principal Countries, 1800, 1850, 1900

$1800^{1}$

\begin{tabular}{|c|c|c|c|c|c|c|c|c|c|c|}
\hline \multicolumn{8}{|c|}{ Country } & \multirow{2}{*}{$\begin{array}{c}\text { Total Population } \\
5,308,482\end{array}$} & \multirow[t]{2}{*}{$\begin{array}{c}\text { Cities of over } \\
100,000\end{array}$} & \multirow{2}{*}{$\begin{array}{c}\begin{array}{c}\text { Cities of over } \\
20,000\end{array} \\
201,416\end{array}$} \\
\hline United St & tates & • & - & - & - & - & - & & & \\
\hline Canada & . . . & $\cdot$ & . & . & . & - & & & & \\
\hline Great Bri & itain an & nd Ir & rela1 & & . & & & $15,717,287$ & $1,032,745$ & $2,083,868$ \\
\hline France & . . . & $\cdot$ & . & . & - & • & . & $26,930,756$ & 767,386 & $1,840,386$ \\
\hline Prussia, $\mathrm{S}$ & Saxony, & , and & d $B$ & ava & aria. & & . & $15,204,799$ & 186,380 & 845,500 \\
\hline Holland a & and Bel & lgiun & $m^{\prime}$ & . & . . & - & . & $4,880,463$ & 217,622 & 721,342 \\
\hline Spain . & . . . & & & & & • & - & $10,836,000$ & 167,607 & $1,112,877$ \\
\hline Portugal & . & . & . & - & . & . & • & $3,661,809$ & 350,000 & 380,000 \\
\hline Italy . & - . & . & - & - & - & • & . & $18,124,000$ & 800,000 & $1,000,000$ \\
\hline Austria & . & . & . & . & - & • & . & $12,600,000$ & 232,000 & 449,000 \\
\hline Hungary & . & - & . & - & & • & - & $9,859,000$ & & 228,000 \\
\hline Greece & . . . & . & • & - & & & . & $1,002,112$ & & 31,125 \\
\hline Norway, & Sweden & n, an & nd I & Den & amar & & & $4,214,810$ & 100,975 & 173,627 \\
\hline Russia & . . . & - & - & • & - & • & • & $45,000,000$ & 595,000 & $1,088,000$ \\
\hline Total & - & - & . & . & . & • & . & $173,340,000$ & $4,448,000$ & $10,156,000$ \\
\hline
\end{tabular}

$1850^{1}$

\begin{tabular}{|c|c|c|c|c|c|c|c|c|}
\hline \multicolumn{6}{|c|}{ Country } & \multirow{2}{*}{$\begin{array}{c}\text { Total Population } \\
23,191,876\end{array}$} & \multirow{2}{*}{$\begin{array}{c}\begin{array}{c}\text { Cities of over } \\
100,000\end{array} \\
1,393,338\end{array}$} & \multirow{2}{*}{$\begin{array}{c}\begin{array}{c}\text { Cities of over } \\
20,000\end{array} \\
2,271,680\end{array}$} \\
\hline United St & tates & - & - & - & - & & & \\
\hline Canada & . . . & • . . & . & . & & $2,375,597$ & & 175,287 \\
\hline Great Bri & itain an & nd Irela & nd. & - & • & $27,390,635$ & $4,791,886$ & $7,640,912$ \\
\hline France & . . . & - . . & . . & . & . & $34,901,938$ & $1,656,900$ & $3,811,500$ \\
\hline Prussia, $\mathrm{S}$ & Saxony, & , and $\mathrm{B}$ & avar & ria. & . & $23,389,303$ & 617,000 & $2,784,000$ \\
\hline Holland a & and Bel & lgium & . . & . . & - & $7,556,879$ & 518,587 & $1,382,703$ \\
\hline Spain . & & & 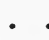 & • & • & $15,464,530$ & 683,921 & $1,489,688$ \\
\hline Portugal & . & . & - & . & . & $3,908,861$ & 275,286 & 415,286 \\
\hline Italy . & - & ${ }^{\circ}$ & & • & & $23,617,000$ & $1,425,000$ & $2,500,000$ \\
\hline Austria & . & . & . & . & . & $17,073,231$ & 484,942 & 720,548 \\
\hline Hungary & . & - & - & • & $\bullet$ & $11,554,377$ & 156,506 & 526,502 \\
\hline Greece & . . & . . & . & . & & & & \\
\hline Norway, & Sweden & $\mathrm{n}$, and & Denr & & - & $6,422,588$ & 123,123 & 297,795 \\
\hline Russia & . . . & $\cdot$ & - & • & & $71,200,000$ & $1,123,698$ & $2,530,954$ \\
\hline Total & . & - & - & . & - & $268,046,709$ & $13,249,987$ & $25,556,875$ \\
\hline
\end{tabular}

1 Compiled from A. F. Weber, The Growth of Cities in the Nineteenth Century. The figures given are for the census years nearest the dates at the head of the tables. 


\section{STATISTICS OF URBAN POPULATION}

$1900^{1}$

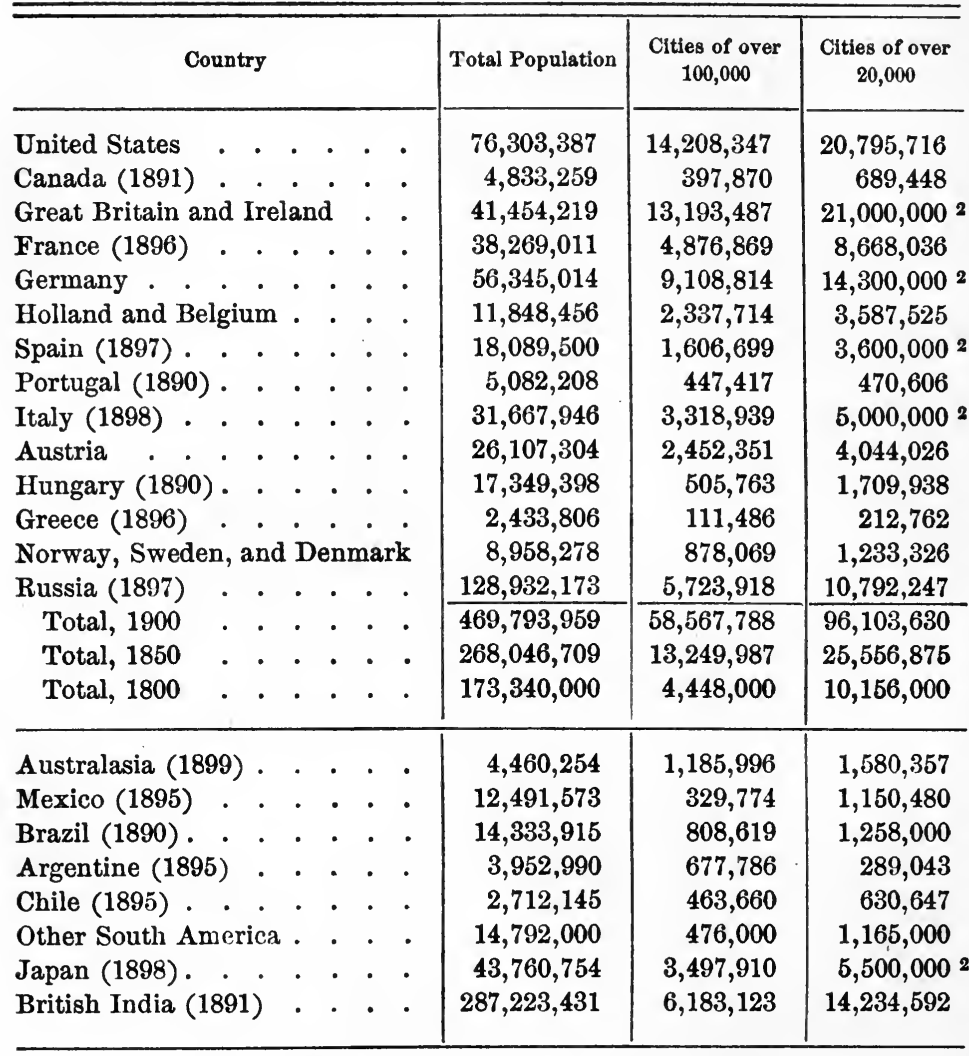

1 United States Census Bulletins, Twelfth Census; Journal of the Royal Statistical Society, June, 1901 ; Annuaire Statistique de la France, 1899 ; Zeitschrift des König. Preuss. Stat. Bureaus, 1901, pp. 39 ff. ; Annuario Statistico Italiano, 1900; Statistische Monatschrift, VI, 41 ; Statesman's Yearbook, 1901.

2 Partly estimated. 


\section{PART II}

\section{MUNICIPAL ACTIVITIES}





\title{
PART II - MUNICIPAL ACTIVITIES
}

\section{CHAPTER VIII}

\author{
Public Health and Safety
}

\section{Police Administration}

Authorities. - Lerox-Bea diev : L'administration locale, etc., Pt. II, ch. 1. -Arminjon: L'administration locale dans l'Angleterre, ch. 8. - F. Brayer: Police administrative et judiciaire (1894). - L. Pelatant: De l'organisation de la police (1899). - H. Delattré : La Gendarmerie Française. - G. Macé: La service de la sureté. - Lours Finux : La Police des Mœurs (1888). - G. Zimmerman : Der modernen Polizei.H. A. Mascher : Die Polizeiverwaltung des Preussischen Staats. - O. Held : Die Preussischen Polizerverwaltung. - Wald Erdmann: Praxis der Polizerwaltung (1891). - R. GNE1sT: Englische Verfassungsgeschichte, II, 804. - J. Stephen : History of the Criminal Law. Arthur Griffiths: Mysteries of Police and Crime (1899), 2 vols. - Encyclopedia Britannica, XIX, 332. - Burss : Encyclopedia of Social Reform.-C. H. Parknurst : Our Fight with Tammany, ch. 20. Report of New York Senate (Lexow) Committee, 1895. - A. E. Costello: The New York Police.-De Francias Folsom: Our Police (Baltimore). - H. O. Sprogle: The Philadelphia Police. - E. H. SAvage: The Boston Watch and Police. - M. Thiriat : L'office de la police judiciaire._Blackwood's Magazine, 29:82;34:642; 36:538; 38 : $319 ; 140$ : 594. — Edinburgh Review, $48: 411 ; 66: 358 ; 96: 1$. Journal of the Royal Statistical Society, 13:221. - Times, 20:12. - Green Bag, $7: 405$. - Cornhill Magazine, $44: 421$. - Eclectic Museum, 1 :552. - Chambers's Journal, 37 :84. - Foreign Revievo, 5 : 205. -Quarterly Review, $37: 489$. - Contemporary Review, 55:445, 622 ; $53: 214$. - Saturday Review, 65 : 534, etc. ; $83: 627$. - Spectator, 60 : 1216; 78:826. - Nuova Antologia, May 16, 1897. - Every Saturday, 9:2, 475. - Canadian Magazine, 14 :362. - Revue des Deux Mondes, $119: 156$. - Nation, $59: 140$. - Chautauquan, $7: 197 ; 16: 689$. - Atlantic Monthly, 80 : 289-300. - Harper's Monthly, 74 : 495-518. - Forum, 27 : 278-284. - Scribner's Magazine, $21: 221$. - Scribner's Monthly, $16: 342$. 


\section{Protection from Fire}

Municipal Affairs, II, 629-636. - Popular Science Monthly, 47 : 477, 603. - Engineering Magazine, 14 : 789, 806; 7 :603. - Public Opinion, 28 : 342. - Forum, 29 : 566-571.

\section{Health Department}

Leroy-Beaulieu : L'administration locale, Pt. II, ch. 5. - John Simon: English Sanitary Institutions. - A. H. Buck : Reference Handbook of Medical Sciences. Articles : Food, Adulteration, Health Legislation, Sanitary Inspection. - Les Institutions Sanitaires en Italie (Milan, 1885). - Rochadd : Encyclopédie d'Hygiène. - American Public Health Association Reports. New York City, Board of Health Reports. - Chicago, Board of Health Report, 1867-1869, with Sanitary History.-G. W. Monton: Health Laws and Ordinances of New York City. - Boston, Board of Health Reports. - Baltimore, Health Department Reports. - A. W. Burry : Manual of Public Health. -Stevenson And Murphy, Treatise on Hygiene.-A. H. Bcck : Hygiene and Public Health. - American Year Book of Medicine and Surgery. - Albert Palmbury, Public Health and its Applications in Different European Countries (1893). - Von Pappenheim: Handbuch der Sanitäts Polizei. - J. S. Billings, in Supplement to Vol. I of Annals of American Academy of Political Science. - American Statistical Association Publications, II, 297. - Popular Science Monthly, 39 : 319-330. - American Architecture, 63:61, 67, 75. - T. W. Aвbotr : Past and Present Condition of Public Hygiene in the United States. - Forum, $15: 304,727$; $16: 346$; $20: 747$. - Engineering Magazine, 3 : 316, New York City. - Journal of Franklin Institute, 143 : 241 ; 137 : 266. - Review of Reviews, 21 :67-70. - North American Review, 170:548-552.

\section{Building Laws}

American Architect, $33: 66,150 ; 35: 38 ; 39: 26 ; 40: 115 ; 58: 74 ; 66: 33$. Builder, November 30, 1895, Municipal Control of Buildings. - Engineering Magazine, 5 : 756-762. - Emden ANd Johnston, Law relating to Buildings. Architectural Record, $1: 69$. - Engineering Record, $40: 119,333,367$. Report Commissioner of Labor, VIII, ch. vi, 96-130. - Stengel: Wörterbuch des Deutschen Verwaltungsrecht, article Baupolizei.

Atlantic, $83: 626,760 ; 84: 18-637,745$. - Forum, $19: 83-94$. - Annals of American Academy, $15: 138-141 ; 16: 160,164$. - Revievo of Reviews, $21: 689$ 696. - Quarterly Journal of Economics, 14 : 378-393. - Contemporary Review, 77 :323-333; Charities Review, $10: 292-297$; Engineering Record, $40: 377$. - Economic Studies, Vol. III.

\section{POLICE ADMINISTRATION}

THE word "police" has a wide variety of meanings. Etymologically, it signifies the entire public activity of the citystate, and in Germany to-day police administration includes 
the whole sphere of internal governmental administration. In a somewhat more limited sense the word is used in the United States to indicate a sphere of governmental action that is definable only to this extent, that it excludes foreign relations and the economic functions of government. The police power of the American states extends to all matters that affect public order and the moral and physical health of the community. In this chapter, however, the word "police" is used in its narrowest sense, to denote the special machinery for the preservation of order and the prevention and detection of crime. This machinery is found more particularly in modern urban municipalities. It consists of an organized and disciplined force of men for the systematic patrol of the public ways and of special magistrates for dealing summarily with the large mass of minor cases which demand prompt decision.

Such machinery in its present form is of recent origin; and, indeed, it is closely connected with the growth of densely populated urban communities. In ancient Rome there was a systematic police administration, at first under the control of the ædiles, who date from the third century of the city; while under the empire a more perfect organization was created. The municipalities of the Roman Empire also had some system of police, modelled after that in Rome. During the feudal centuries, however, we find no trace of any organized police systems, although the manorial lords exercised police jurisdiction in connection with their judicial administration. In the mediæval free cities this police jurisdiction passed from the lords to the city authorities; but there was no patrol service or organized police force in the modern sense of the word. 1

\section{Evolution of the Modern Municipal Police}

$\Gamma$ The first steps toward the modern system were taken in France. Under Philip of Valois there were definitely estab-

1 Even Venice had nothing approaching the modern urban constabulary. See W. C. Hazlitt, The Venetian Republic, II, 516-519. 
lished at Paris in 1327 a number of commissaires, royal officers distinct from the judicial system, with power to conduct. preliminary examinations and investigations in the enforcement of law and order. In other towns in France no attempt was made to separate the police magistracy from the judicial system until 1514, when similar commissaires were appointed in each royal bailliage. The beginnings of an organized police force may be dated from the establishment, in 1356, of a military body known as the maréchaussée, to take cognizance of crimes committed by soldiers in the king's service. The jurisdiction of this force included deserters from the army, and thus reached one important class of those likely to cause public disturbances; in time its authority was extended to include all assaults, robberies, and murders committed on the highways; and it is from this body, reorganized in 1720, that the present gendarmerie of France has developed.

An important step in the development of a systematic police patrol of urban communities was the creation of a lieutenant of police for Paris in 1667, under whom was a body of soldiers acting as guards for the city. In 1669 a lieutenant of police was appointed by the king for each town in France where there was a parlement or presidial court, and later the system was extended to other provincial cities.

The police arrangements of Paris continued to be the most advanced in any European city, and a description of the system there in 1763 will indicate the highest development reached up to that time. /There were then 48 commissaires of police, whose duties resembled those of the English justices of the peace; but the offices in France were salaried and were filled by men of a lower social standing than the English country justices. The patrol force consisted altogether of 750 men, of whom 600 constituted practically a military force, armed and disciplined, and one-third of them mounted. The day force did not attempt any continuous patrol of the streets, but was stationed at certain posts, ready to act in case of an unusual public disturbance. The night patrol was more systematic; but it is significant of the conditions of the 
time that the guards performed their duty not individually, but always in small bands. ${ }^{1}$

In other French cities there was less attempt at a systematic patrol of the streets than in the capital. Indeed, the police system for the whole of France, which was under the immediate control of a royal minister, was a political organization, whose principal function was the detection and suppression of attacks on the government, while the maintenance of peace and order was but incidental. Some of the German states had a less developed, but similar centralized police system, mainly political in nature. Even in Berlin there seems to have been no regular day patrol, and the night watch at the middle of the eighteenth century consisted of but fifty-four men. ${ }^{2}$ For the suppression of serious outbreaks in the cities, the military forces were called into action.

Urban police arrangements in England at the end of the eighteenth century were even more primitive than those in the continental cities. The primary feature in the English system was the justice of the peace, an office dating from the reign of Edward III. The justices were appointed by the Crown; but, as they were chosen from the local gentry, served without salary, and were subject to no active administrative control by the central government, they were, in practice, independent local officials, radically different from the commissaires of police in the French system. Each justice had under his direction a small number of parish constables, who were in no sense trained officers, but persons serving transiently, and acting mainly under specific instructions from the justices. In the towns the inhabitants were charged by the statute of Winchester ${ }^{3}$ with the additional duty of watch and ward; but this service, like that of the justices, was entirely gratuitous, and no effective watch was maintained.

This system of unpaid justices and constables, which had worked satisfactorily under rural conditions, did not prove

1 W. Mildmay, Police of Paris (1763), pp. $43 \mathrm{ff}$.

2 Revue des Deux Mondes, CCXXVII, 159.

83 Edward I, ch. iv. 
adapted to urban communities. The first step toward a change was made during the latter part of the eighteenth century, when certain boroughs and London parishes received special parliamentary authority to employ a force of paid night watchmen, and to levy a local rate for their support. The watchmen appointed were, however, poorly paid; they followed regular occupations during the day, and they were subject to no training or discipline. Moreover, with the increase of urban population, the work of the justices became so great and, at the same time, so repulsive, that men of standing withdrew from the task, and the places were occupied by men attracted by the opportunities for pecuniary gain and extortion. About the middle of the eighteenth century a responsible presiding magistrate with a salary was appointed to the Bow Street Court in the city of London, 1 and the improved conditions that followed gave to the court a deserved celebrity in the annals of the time. But the numerous population outside of the jurisdiction of the city magistrate was not affected by this change; and it was not until 1792 that a law was enacted (the Middlesex Justices Bill) providing for the metropolitan community seven additional police courts, with permanent salaried magistrates.

The constable and night-watch systems had remained up to this time in their former crudeness. Their inadequacy to the urban conditions which had arisen was more especially shown in London, where the jurisdiction of a watch commission never extended beyond a single parish, and in some parishes there were several watch commissions, St. Pancras having no less than eighteen. Thus it often happened that the watchman on one side of a street could not help one on the other side, because they were in different parishes or watch districts. At the same time, many metropolitan parishes had no systematic night watch, and in a few cases there were no night watchmen at all. 2$]$ Each magistrate had a small body of police officers attached to his court, but their duties were confined to the execution of specific orders, and

1 The novelist Fielding at one time occupied this position.

2 Contemporary Review, LV, 624. 
there was no system of day patrol. The inevitable result of such conditions was a startling prevalence of crime and disorder, while in cases of serious disturbance peace was preserved only by the display of military force.

A small improvement was made in 1805 , when a patrol was organized for the central part of London during the early hours of the night. But it was not until 1828 that the great step was taken in the passage of Peel's Act. This swept away the old parochial organizations for police purposes in the metropolis, and established a new constabulary force for the entire district, under commissioners appointed by the Crown - the first modern police force in the world. The act provided for a thoroughly organized corps of policemen, subject to strict training and discipline; a systematic day and night patrol of the whole area, which was divided into sections and definite beats for each officer; a force of reserves stationed at the police headquarters, and mobilizing arrangements for suppressing serious tumults. ${ }^{1}$ As first established, the new system did not abolish the police of the city of London, the Thames River police, or the constables of the magistrates; but in 1839 the latter two classes were absorbed, and in the same year the city reorganized its police force on the new model.

This new police system in London was bitterly attacked, as "one of the greatest inroads on the principles and practice of the British constitution that modern times have witnessed." 2 The new police officer was styled a mercenary, a hireling, a slave of the executive, charged with detestable duties and intrusted with arbitrary power. Nevertheless, the main features of the system, with the exception of direct control by the central government, were rapidly adopted in other British cities. The Municipal Corporations Act of 1835 authorized the organization of police corps in all boroughs, each force to be under the control of the mayor and the watch committee of the council; and by 1840, when the metropolitan force consisted of some $3500 \mathrm{men}$, that of

1 Edinburgh Review, XCVI, 1.

2 Blackwood's Magazire, XXIX, 85. 
Liverpool had 600 men, Manchester 325, and Birmingham 300 . In 1839 the formation of county police for the smaller towns and rural districts was authorized. In 1856 the system of county police was made compulsory; and at the same time a scheme of inspection of all the local police by the central government was organized, in connection with subsidies paid by the central government toward the cost of the local police.

$\sqrt{E}$ arly arrangements for the preservation of peace and order in American cities were much the same as in the English towns, and the establishment of a well-organized police system in this country followed after the new English system was well under way. Thus, in New York city, in 1840, when the population numbered 310,000 , the police consisted of 2 constables elected in each of the 17 wards, a body of about 100 men called mayor's marshals, a night watch of some 300 citizens, who during the day pursued their occupations as cartmen, stevedores, porters, etc., and about 100 other officials with a large variety of titles, such as wardens, bellringers, and inspectors of various kinds. ${ }^{1}$ There was evidently no systematic day patrol, and the various classes of officials had no effective organization.J Philadelphia in 1833 had a body of 24 day policemen and 120 night watchmen. Boston in 1849 had 22 day police and 200 night watchmen, each class forming an entirely distinct force. Other cities had similarly small bodies of constables and police officers, with a considerable number of night watchmen; but in no case was there any efficient organization, training, or discipline in the service.

A legislative statute of May, 1844, abolished the long list of officials in New York city and provided for a single body of police, and about a year afterward the new system went into operation. The new force consisted of 800 men. The chief was appointed by the mayor, with the consent of the council; while the captains and men were appointed annually in each ward by the alderman, assistant alderman, and assessor from the ward. It is obvious that with such a

1 Costello, Our Police Protectors, p. 102 ; Scribner's Magazine, XVI, 342. 
method of appointment the police officers could not become a permanent force, while the defective discipline and organization are indicated by the fact that the members of the force prevented the adoption of a uniform. In 1853 some changes were introduced which effected considerable improvement. The mayor, recorder, and city judge were created a board of police commissioners, with full power of appointing members of the force, who were to hold their positions during good behavior, thus establishing a permanent force capable of discipline and organized action. By degrees, too, a uniform was introduced, and was accepted by the men.]

The example of New York was soon followed by other cities. In 1850 a police district was created, including Philadelphia and its suburbs, in which an organized police force of 800 men was established. ${ }^{1}$ By the extension of the boundaries of Philadelphia in 1853, this force became a branch of the government of the enlarged city. It was not, however, until 1860 that uniforms were adopted for the Philadelphia police. In Boston the dual system of watch and police was abolished in 1854, and the Boston Police Department established with 250 men. $^{2}$ The Baltimore police force was established in 1857 with 350 uniformed officers. ${ }^{3}$ $\Gamma \overline{\mathrm{U}}$ to this time the police in American cities had been entirely under the control of local officials. But in 1857 the New York legislature established a metropolitan police district, including New York city, Brooklyn, and surrounding territory, and created a state commission to control the police administration in this district Similar state police boards were provided for Baltimore in 1860, St. Louis and Chicago in 1861, Detroit in 1865, and Cleveland in 1866.J In the last-named city the state board continued only two years; in Chicago, only until 1865; and that in New York was abolished in 1870. The Detroit state board, however, continued until 1891; the Baltimore and St. Louis boards are still state authorities; while more recently other state boards for par-

1 H. O. Sprogle, The Philadelphia Police.

2 E. H. Savage, The Boston Watch and Police.

$\checkmark$ De Francias Folsom, Our Police. 
ticular cities have been established, notably for Boston in $\mathbf{1 8 8 5}$ and for Cincinnati in $\mathbf{1 8 7 6 .}$

On the continent of Europe there have also been important developments in police administration during the nineteenth century. In 1812 Prussia established a military gendarmerie on the general lines of the French organization, ${ }^{1}$ and in 1830 authorized the municipal authorities of any city where no garrison was stationed to establish a local police force. ${ }^{2}$ But for the continent in general the military was, during the first half of the century, the most important factor in maintaining order. Thus the civil police of Paris in 1854 consisted of only 450 men on patrol duty and 300 other men on special duties, ${ }^{3}$ while the main task of preserving peace fell to small garrisons of soldiers in various parts of the city. In that year, however, the police system of Paris was reorganized, somewhat on the lines of the London police. The soldiers were removed and a systematic patrol system established, with a force of 3000 men. This body was under the direct control of the central government, which paid a part of the additional expense of the new system. Since that time, in other continental cities, the main features of the English system have been adopted, but the police on the continent of Europe remain even now a more military body than the English police.

At the present time, not only in the large urban centres throughout the world, but also in overy considerable town in Europe and America, there is to be found an organized, uniformed, and disciplined police force. The various bodies in Great Britain aggregate 47,000 men; and in the United States, in cities of over 30,000 population, there are 28,000 policemen. The metropolitan police of London, numbering 15,000 men, is by far the largest force under a single direction; the Paris police includes about 8000 men, that of New York 7500, Berlin 4500, Vienna 3500, Chicago 3000, Philadelphia 2400. In the smaller cities the size of the force is

1 Bornhak, Preussisches Verwaltungsrecht, II, 126.

2 Von Ronne, Staatsrecht der Preuss. Monarchie, II, 2, p. 98.

3 Block, Administration de Paris, p. 767. 
not only less absolutely, but - and this is significant - is in every country less in proportion to population than in the largest cities. Cities of about 50,000 inhabitants frequently have not more than 5 or 6 policemen to each 10,000 of population; in cities of about 100,000 population the number of policemen usually averages at least 10 per 10,000 ; where the population is as large as 500,000 , there are generally somewhere near 15 policemen per 10,000; while of the largest cities New York has 20, London 24, Berlin 25, and Paris over 30 policemen to each 10,000 inhabitants.

This increasing proportion of policemen in the larger cities emphasizes what has already been indicated in noting the recent development of the present police system, that there is a close relation between urban conditions and the police patrol. In a thinly settled community crowds cannot easily gather, the residents are well known to each other, and strangers are quickly noted. Under these conditions violations of law and order can be readily traced and wrong-doers quickly apprehended. But in a densely populated city, where outsiders continually come and go, and where even the inhabitants are strangers to one another, there are large opportunities for criminals to escape and for riotous disturbances to develop. It is these conditions which have led to the development of a systematic and disciplined police; and, since the conditions are accentuated in the larger cities, these great urban communities demand a more than proportional development of their police system. This rule is, like all such empirical rules, true only in the main; and exceptional conditions demand unusual police strength in some cities not of the largest size, as in Dublin, Calcutta, and some of the principal cities of South America. In the United States, cities in the South, including Washington, have a larger proportion of policemen than the Northern cities, probably on account of the large negro population. Other variations are not so easily explained. Thus, it is not evident why Detroit, New Haven, Albany, and Troy should find it necessary to have a larger police force than most cities 
of the same population, or why Chicago, Cleveland, and Denver have a smaller force than the average. ${ }^{1}$

\section{Organization of Municipal Police}

Since the police force of each city forms a distinct corps, the system of organization in different cities varies widely; but, nevertheless, some general features in the organization of the trained uniformed force can be noted.

In very small eities the only division of labor is that between the head of the force and the small body of privates or patrolmen; but when the force is somewhat larger, it is usually organized after the model of a military company. In the first rank above the patrolmen are certain officers, called in America roundsmen or sergeants, who make periodic tours of the city to make sure that the patrolmen are at their posts. Above these is a lieutenant or sergeant, stationed at headquarters, over whom is the captain or chief. For the larger cities this organization becomes a unit in a more complex system. The city is divided into a number of police districts, or precincts, each of which has a station and a detachment of men organized in a way similar to that just described, while above the various precinct captains is the chief of police for the entire city. In the great cities the precincts are organized in groups, each group having at its head an officer intermediate between the chief and the captains. The metropolitan cities find necessary additional intermediate offices, so that in New York, for example, the hierarchy of police officers is: chief, ${ }^{2}$ deputy chiefs, inspectors, captains, sergeants, roundsmen, and patrolmen. Moreover, in the large cities there are also organized special detachments outside of the regular precinct organization, such as the mounted squad, the bicycle squad, the river or harbor police, the sanitary police, and the detective bureau.

Over the permanent corps of disciplined, trained, and uni-

1 Cf. Bulletin of the Department of Labor, September, 1900.

2 In the spring of 1901 the office of chief of police in New York city was legislated out of existence ; but the former incumbent was made first deputy commissioner, and in this capacity continued to direct the force. 
formed police there is a system of external non-professional control. But while the organization of the permanent force is, in general, along the lines indicated, the methods of control are not only far from uniform, but represent radically different ideas. These differences exist both in the composition of the lay authority and in its relation to the central governments and municipalities.

As to the composition of the higher police authority, there are two principal systems: that of the board or committee, and that of the single head. The latter is practically universal throughout continental Europe, where the maire, burgomaster, or prefect has immediate control of the chief of police. The same system prevails in most of the less important cities in the United States; and in a number of the large cities, such as New York, ${ }^{1}$ Chicago, Philadelphia, Cleveland, Detroit, ${ }^{1}$ Minneapolis, Syracuse, Rochester, Albany, and Troy, a single director or superintendent exercises the civil control over the permanent force. The board system of control is employed throughout Great Britain, where the watch committee of the municipal council - an unsalaried and slowly changing body - is the supervising authority. Over the metropolitan police for London there is a commissioner and three assistant commissioners, forming a salaried board, in which the chairman is much the most important member.

The system of appointed salaried police boards was at one time almost universal in large American cities; and while in many places these boards have been replaced by single officials, the board system is still to be found in St. Louis, Boston, Cincinnati, and New Orleans. The Boston police commission has three members; that of New Orleans, six; the other cities named have each four; while the statutes generally require that not more than two shall be members of the same political party. This requirement, that the boards shall be bi-partisan, has been established ostensibly because the machinery of elections is often under the control of the police authorities, so that precautions are necessary

1 Since the spring of 1901. 
to prevent one party from controlling this machinery. The system, however, seriously affects the administration of the police. Deadlocks in bi-partisan boards are avoidable only by "deals" between the representatives of the two parties, while neither party can be held responsible for mismanagement. With a separate election bureau there is no adequate reason for a bi-partisan police board; indeed, there is little reason for a board of any kind, since a single police director is a more efficient and a more responsible authority.

It is important to note the great variety of forms which the relations of state and municipal authorities present in respect to police administration. In this field, more than in any other, which is in any sense considered a municipal function, the higher governmental authorities have asserted and exercised their power to inspect, to supervise, and even to assume the entire management.

The most important regions where the entire police system exists as a purely state institution, with no local control, are certain countries under British authority: Ireland, India, the South African and Australian colonies, Egypt, and smaller dependencies under the British Crown. The Royal Irish Constabulary, which is the only police throughout Ireland, is almost a military force; it is well drilled, occupies barracks in the various towns, and is under the immediate control of the executive government at Dublin. In India the urban police is under the direction of the central governments in the various provinces, although the larger municipalities make contributions toward the support of the forces on duty within their respective limits. New South Wales, the principal Australian state, is divided into eleven police districts, the metropolitan area, including Sydney and suburbs, forming one; and in each district the police force is under an inspector-general and superintendent of police, appointed by the state government.

In Russia, Bavaria, Württemberg, and Greece the entire police system is almost equally centralized. For each of the large Russian cities there is a master of police, appointed by 
the government, who determines the numerical strength of the force, the disciplinary rules, salaries, and appointments. The expenditure is paid by the municipal authorities; but they have no option in the matter, as the central government makes this an obligatory item in the budget.

While the entire police system in Prussia is not so completely centralized, in most of the important Prussian cities the immediate direction of the local police is in charge of a special commissioner appointed by the king. Twenty-one cities have such commissioners, the list including Berlin, all the cities with over 150,000 inhabitants, and six of the eighteen with from 50,000 to 150,000 population. This feature of the Prussian system is found on a less extended scale in almost every other country where the general police system is largely under municipal control. In London, ${ }^{1}$ Paris, Lyons, Vienna, and other European capitals the local police forces are under the immediate control of the various contral governments. So, too, in the city of Mexico, in Rio de Janeiro, Buenos Ayres, and Tokio the police are a part of the national, and not of the municipal, administration. Even in the United States there are a number of important instances where the police force is under the management of a board appointed by the state government. This is now the case in St. Louis, Boston, Baltimore, Cincinnati, and San Francisco (five of the ten largest cities); also in Washington, Denver, Newport (R.I.), Kansas City, Fall River, St. Joseph, Birmingham, Manchester (N.H.), and in eleven Indiana cities. ${ }^{2}$

In Europe the system of state police administration is often accompanied by grants from the central government toward the support of the police. Four-fifths of the cost of the Berlin police and one-third of the cost of the London and Paris police are paid in this way. On the other hand, in the

1 The metropolitan police district is much larger than the administrative county of London. It includes all of the parishes within fifteen miles of Charing Cross, and contains 690 square miles, with a population of $6,578,000$.

2 Terre Haute, South Bend, Anderson, Elkhart, Richmond, Huntington, Jeffersonville, La Fayette, Logansport, Muncie, and New Albany. 
American cities even where there is a state police board, the entire cost of the police is paid by the municipality.

Many countries, where there are local police, have also a force of state police, under the immediate charge of the central government. These state forces are, in most cases, modelled after the French gendarmerie. This is a branch of the regular army, enlisted, organized, and controlled by the military department. The gendarmes act as a sort of mounted police: in the cities they conduct prisoners from jails to courts and stand by them in criminal docks, are stationed at theatres and other places of public amusement, and line the streets to keep order during pageants; while in the country districts they do the regular work of patrol. Similar organizations, under the direct control of the central governments, are to be found in Belgium, the Netherlands, Austria, Italy, Portugal, Spain, Mexico, and most of the South American countries. The Canadian mounted police, organized by the Dominion government and employed in the preservation of order in the Northwest territories, also resemble the European gendarmerie.

In the countries of continental Europe just mentioned the local police are, to some extent, under municipal control, but are also subject to a large degree of supervision by the central governments. This central supervision is probably strongest in France and Prussia. The maires of the French communes, who are elected by the local councils, have the power of appointing the police officers. They do so, however, not as representatives of the municipality, but in their capacity as agents of the state; and their appointments must be accepted by the prefect of the department, who has also the right of revoking the suspension and preventing the removal of any officer. Moreover, it is not the council but the maire (again subject to the control of the prefect) who makes police regulations. Further, in all cities of over 40,000 population, the organization of the local force is regulated by a decree of the president of the republic, and the function of the municipal council is confined to recommending a scheme. Finally, the commissaires of police in all 
cities of over 6000 population are appointed by the president, on the recommendation of the minister of the interior, and thus furnish the means for an effective supervision over the local officials. The expense of the police is borne by the municipalities; but this is one of the obligatory expenditures which the central government can compel the city to make.

In those Prussian cities where there is not a state police, appointments to the police force are made by the municipal authorities, subject to the approval of the higher governmental officials, who also frame the rules of organization. The expenses of the police are paid by the cities, but as a contribution toward the state administration; and even the local police are classed distinctly, not as a part of the municipal service, but as a branch of the state administration.

The system of central control in Italy is no less complete than in France. In Austria and Belgium the local authorities have a slightly larger degree of autonomy. In Belgium the municipal councils enact police ordinances without the necessity of securing the approval of a higher authority, and the central government appoints the commissaires of police only in the larger cities.

Outside of the metropolitan district, the British police system allows a greater degree of local control. In the larger cities, including the sixty county boroughs and most of the other municipal boroughs, the immediate responsibility for the management of the police rests with the watch committees of the town councils. In most towns of less than 10,000 inhabitants, and in sixty of larger size, ${ }^{1}$ the urban police form part of the county police under the control of the county authorities. There is, however, over both borough and county police a thorough system of supervision by the inspectors of the Home Office. This inspection requires the local authorities to keep their police up to a given standard of efficiency, under penalty of losing the parliamentary grant, which amounts, in general, to about one-half of the total cost of the police.

1 The largest boroughs guarded by county police are West Bromwich $(59,000)$ and Dudley $(45,000)$. 
In the United States the police arrangements for most cities allow the municipal authorities a much larger field of action. Apart from the important cases of state commissions already.mentioned, the cities maintain and direct their own police, subject to no active administrative control on the part of the state authorities. Even the police magistrates are generally locally selected, either by popular election or by municipal appointment. For many large cities, however, the organization of the police is determined in great detail by legislative enactments; while the statutes requiring the police board to be bi-partisan still further limit the independence and responsibility of the local authorities in the management of the police.

Nevertheless, the courts in the United States have repeatedly declared that police officers are not private or corporate officers of the municipalities, but public or state officers, and that where the municipality has immediate control, it is acting as agent of the state government. This opinion has been set forth in the decisions upholding statutes providing for state-appointed police boards in New York, Michigan, Massachusetts, Nebraska, Kansas, and Maryland. ${ }^{1}$ In New York, however, while a state commission was allowed for a police district covering a territory much larger than any city, an act making a single city into a police district with a state commission was declared in violation of the constitutional provision that "municipal officers shall be elected by the electors of the municipality or appointed by the authorities thereof." 2 In Kentucky, also, it has been held that a statute for the appointment. of police officers by the governor was rendered void by a constitutional provision that municipal officers shall be elected. ${ }^{3}$

Even where police officers are appointed by the city, they are held by the courts to be public officers, and not agents or

1 People $v$. Mahaney, 13 Mich. 481 ; Commonwealth $v$. Plaisted, 148 Mass. 374 ; State $v$. Leavy, 22 Neb. 474 ; State $v$. Hunter, 38 Kans. 578 ; People $v$. Mayor, 15 Md. 376 ; People $v$. Draper, 15 N. Y. 532.

2 People $v$. Albertson, 55 N. Y. 50.

8 Shad $v$. Crawford, 3 Metcalfe, Kentucky, 207. 
servants of the city, in such a sense as to render it responsible for their unlawful or negligent acts in the discharge of their duties. 1 This rule is well stated in the case of Buttrick $v$. the City of Lowell:-

Police officers can in no sense be regarded as agents or servants of the city. Their duties are of a public nature. Their appointment is devolved on cities and towns by the legislature as a convenient mode of exercising a function of government; but this does not render them liable for their unlawful and negligent acts. The detention and arrest of offenders, the preservation of the public peace, the enforcement of the laws, and other similar powers and duties with which police officers and constables are intrusted are derived from the law, and not from the city or town under which they hold their appointment. For the mode in which they exercise their powers and duties, the ${ }^{\bullet}$ city or town cannot be held liable.

While thus it must be frankly recognized that even in the United States the city is not an independent political unit in police matters, it does not follow that the European system of state police is in accordance with American institutions or an advisable innovation to introduce. The police, even when controlled by state commissions in American cities, are supported from local taxes. Their work is intimately connected with almost every other municipal department, and the necessary spirit of coöperation is not promoted by making the police independent of the municipal authorities. Moreover, much of their work is in the enforcement of local ordinances. For these reasons it is important that the primary control of the police force should be vested in the representatives of the municipality.

At the same time, however, it is equally important to recognize that the public nature of the police authority fully warrants the state government in establishing a large measure of supervision over the municipal police. The state has a right to require the local police to enforce the state laws,

1 Buttrick v. Lowell, 1 Allen (Mass.), 172 ; Caldwell v. Boone, 51 Iowa, 687 ; Odell $v$. Schroeder, 58 Ill. 353 ; Prather $v$. Lexington, 13 B. Monroe ( Ky.), 559 ; Worley $v$. Columbia, 88 Mo. 106 ; Lafayette $v$. Timberlake, 88 Ind. 330 ; Norristown v. Fitzpatrick, 94 Pa. St. 121 ; Hannon v. Agnew, 96 N. Y. 439. 
and, for this purpose, to establish a system of inspection, with power to remove delinquent officials. A state police bureau could also act as a clearing house for the detective work of the police, and provide an official organization which would make more effective the coöperation of police authorities in different cities. A small force of state police (such as already exists, on a very diminutive scale, in Massachusetts) ${ }^{1}$ could be of service in suppressing disorder in rural districts and in enforcing such state laws as the local police fail to enforce. Such a combination of state and local action is already employed in many states in the work of public charity, education, and health regulation. The work of the police equally concerns the state and the localities; and here, too, a system of coöperative dual administration will prove more effective than either a state police or independent municipal police.

\section{Duties of the Police}

Some light may be thrown on these problems of organization by noting, in some detail, the duties of the police. The English lighting and watching statute of 1833 contained the following provision:-

During the time they shall be on duty, the policemen shall : use their utmost endeavors to prevent all robberies, burglaries, and other felonies and misdemeanors, and other outrages, disorders, and breaches of the peace; and to apprehend and secure all felons, rogues, vagabonds, and disorderly persons who shall disturb the public peace, or any party or persons wandering, secreting, or misbehaving himself, herself, or themselves, or whom they shall have reasonable cause to suspect of any evil designs; and to secure and keep in safe custody any such person, in order that he or she may be conveyed as soon as conveniently may be before a justice of the peace to be examined and dealt with according to law. ${ }^{2}$

The duties here laid down are still the most important functions of the police, and it is in the discharge of these functions that the policemen have the special power to arrest persons without warrant, when taken in some criminal act.

1 R. H. Whitten, Public Administration in Massachusetts, ch. 6.

$23 \& 4$ Wm. IV, ch. 40, § 41. 
But the policemen of to-day perform many other tasks not specifically included in the above. They regulate street traffic, so as to prevent blockades and permit foot passengers to cross the streets in safety; they keep in order, and within proper limits, the crowds which gather at fires and processions, and on other occasions; they perform a sort of ambulance work in cases of street accidents, illness, and drunkenness; they pick up and restore lost and runaway children; and they attempt to keep disorderly women from soliciting on the streets. The enumeration in the New York charter of 1897 will give a general view of the more important duties now undertaken by policemen in most large cities :-

It is hereby made the duty of the police department and force, at all times of the day and night, and the members of such force are hereby thereunto empowered to especially preserve the public peace, prevent crime, detect and arrest offenders, suppress riots, mobs, and insurrections, disperse unlawful or dangerous assemblages, and assemblages which obstruct the free passage of public streets, sidewalks, parks, and places; protect the rights of persons and property, guard the public health, preserve order at elections and all public meetings and assemblages; regulate the movement of teams and vehicles in streets, bridges, squares, parks, and public places, and remove all nuisances in the public streets, parks, and public places, arrest all street mendicants and beggars; provide proper police attendance at fires; assist, advise, and protect emigrants, strangers, and travellers in public streets, at steamboat and ship landings and at railroad stations; carefully observe and inspect all places of public amusement, all places of business having excise or other licenses to carry on any business; all houses of ill-fame or prostitution, and houses where common prostitutes resort or reside; all lottery offices, policy shops, and places where lottery tickets or lottery policies are sold and offered for sale; all gambling houses, cock pits, rat pits, and public common dance houses, and to repress and restrain all unlawful or disorderly conduct or practices therein; enforce and prevent the violation of all laws and ordinances in force in said city; and for these purposes to arrest all persons guilty of violating any law or ordinance for the suppression or punishment of crimes or offences.

Police action in the directions thus far indicated is, generally speaking, similar in all the leading countries of the world. In some matters, however, there are important differences, especially between the continental police and the 
police in English-speaking countries. Thus, in the countries of continental Europe, more especially in France, the police exercise a close surveillance over both inhabitants and visitors, keeping accurate and detailed records of the important facts as to the family, life, occupation, and movements of large numbers of persons. To make this surveillance as complete as possible, the Paris policemen are located on permanent beats, so that each may become thoroughly acquainted with the inhabitants of his district; at the same time the 20,000 concierges scattered throughout the city act as a system of private detectives, being required to report every suspicious fact to the police; and temporary lodgers must be reported by all hotels and boarding-houses. The information collected from these various sources for the whole of France is brought together and collated at the detective bureau in Paris. The criminal and suspicious classes are now the especial subjects of this surveillance, and the information is of great value in the detective work of the police. In Berlin the police compile the city directory from these records. But the machinery is also available, and in the past has been used for tracing out and suppressing political movements; and in this respect it is a powerful and dangerous weapon in the hands of the government.

In English-speaking countries there is no such detailed police surveillance. In each city police force there is a detective corps which keeps records of convicted criminals, and the detective bureau of the London metropolitan police acts as a central detective agency for the entire kingdom. In the United States, although the records of one city are usually open to the police officers of other cities, there is no official bureau or clearing house where all the information can be brought together and properly collated. ${ }^{1}$

1 There is a bureau of identification at Chicago, maintained by voluntary subscriptions from the principal cities; and an effort is now being made by the Association of the Chiefs of Police of the United States and Canada to have the national government organize and support an official bureau. Such a national bureau, however, could not exercise any compulsory control over municipal authorities. 
A further duty of modern police is the control and limitation of vice. In the large cities of continental Europe there is, distinct from the patrol force, a body of "morality police" (police des moeurs) charged especially with this work. The regulations generally include a system of licensing houses of ill-fame, the medical examination of the inmates at certain intervals, and the provision of special hospital accommodation for the treatment of venereal diseases. A similar system of medical inspection has been in force in Hong Kong, Bombay, Malta, New South Wales, and some Japanese ports, and was for a time enforced by the British government at certain army stations in Great Britain. This system of public regulation is defended by foreign writers on the ground that it, to some degree, lessens the physical evils resulting from sexual immorality. The regulations of some cities have attempted to distinguish between measures for sanitary control and the legal recognition of vice. Thus, the Hamburg rules state that registration simply means that the evil is tolerated and not that it is allowed, approved, or authorized. In spite of drastic efforts to enforce the regulations, at times subjecting innocent persons to most degrading treatment, it does not seem to have been possible in any city to prevent clandestine and unregulated vice on a considerable scale.

Under the statutes of most English-speaking countries the duties of the police in the interest of public morality require them to suppress both houses of ill-fame and gambling, and frequently, also, Sunday traffic. In most rural districts public sentiment serves to enforce such laws, but in the urban districts they are generally violated. Usually the police do not attempt to enforce the law rigidly, but establish extralegal restrictions; and in some Western cities in the United States there is a well-defined system of monthly fines, which, in practice, operates as a licensing system. In particular cases it is freely charged that the police are corrupt and, for a due consideration, allow an almost unrestrained violation of the law.

The regulation and control of the retail traffic in intoxi- 
cating liquor is another police function. In most countries dealers must secure permissive licenses before commencing business, various restrictions are placed on the conduct of the business, and in the United States heavy license fees or taxes are imposed. The relation of the municipalities to the system of control varies widely in the different countries.

Most often the granting of licenses is not a municipal function. In Prussia, Austria, Greece, British India, and Egypt licenses are granted by agents of the central governments; in Belgium and Italy, by the provincial authorities; in England and the British colonies, by the justices of the peace. In France no license is required, but each person opening a saloon must make a declaration of his intention at the office of the maire. The municipal authorities control licenses, as a rule, in Holland, Portugal, Norway, Sweden, Mexico, Argentina, and Japan.

In the United States most of the larger cities do not control the licensing of saloons. While the municipalities issue licenses in the larger number of states, in the most important urban states (New York, Pennsylvania, Ohio), and also in Connecticut, Virginia, Georgia, and Florida, the licensing authority is a county or state officer. Moreover, in Missouri and Massachusetts, the large cities - Boston, St. Louis, and Kansas City - have state license officers. In several states, cities may, by popular vote, prohibit the retail liquor trade within their limits; but Cambridge and Somerville, in Massachusetts, are the only cities of importance which have permanently adopted this policy.

The revenue from high license fees or taxes on liquor saloons in the United States always goes, in large part, to the city treasuries. In New Jersey, Illinois, Wisconsin, Minnesota, and Colorado the cities retain the full amount of the tax authorized by the state, and also in San Francisco and Washington the local tax goes entirely to the municipal treasury. Elsewhere a part of the revenue goes to the county or state treasury; in New York one-third and in Massachusetts one-fourth of the liquor revenue falls to the state.

Enforcement of the special restrictions on the liquor trade 
is among the duties of the police. The failure of municipal police to enforce the strict state regulations in large cities has been one of the most important factors in securing the systems of state police which exist in the United States. In Boston police administration under the state board seems to be distinctly better than formerly; but usually direct state administration has produced only temporary improvement; while, when the motive of the change has been partisan advantage, the resulting administration has been worse than with municipal administration. ${ }^{1}$ In the face of these facts it cannot be maintained that a system of state police is a satisfactory permanent remedy for inefficiency or corruption in the municipal police.

This does not mean, however, that the municipal police need be left free to neglect or ignore state laws. There remains the system, already mentioned, of a state administrative supervision over municipal officials. Through this system, indorsed as it is by experience in other lines of public activity, it is possible at the same time to preserve local autonomy, to secure administrative efficiency, and to maintain the interests of the state.

\section{PROTECTION FROM FIRE}

The work of the police provides measures against public dangers arising from the action of human agents. There are other dangers to public security from non-human forces; and of these the danger from fires is in urban centres one of the most constant and the most perilous. The compact nature of city building makes easy the rapid spread of a fire from one edifice to another ; so that a burning city house is not merely a calamity to the owner and occupier, but also an immediate threatening danger to the entire community in the neighborhood. Since the danger is confined to the local community, the methods of escaping the danger are usually, very appropriately, under municipal control.

1 C. M. L. Sites, Centralized Administration of Liquor Lawos, especially pp. $55,155$. 


\section{Fire Insurance}

The earliest steps in the development of fire insurance were made by public authorities in cities, and at the present time this is a governmental function in certain places. The first form of fire insurance which appears in the records of continental Europe is a law enacted by the court of Flanders in 1240 , requiring damage by fire to be made good by the whole locality in which it occurred. A chamber of insurance is said to have been opened at Bruges in 1310. Details for the centuries immediately succeeding are lacking; but by the seventeenth century Hamburg and other continental ports had municipal insurance. ${ }^{1}$

After the great fire of London (1666) the corporation of the city was looked upon as the proper authority to organize and conduct fire insurance. In 1660, when asked by the king to aid in establishing a scheme of fire insurance by others, the corporation had replied that such an enterprise should be conducted by the municipality. But it was not until 1681 that a definite plan was prepared, and a guarantee fund of $£ 100,000$ constituted. About the same time, however, a private project was established which waged war on the municipal enterprise by lower rates and in lampoons and broadsides ; and in November, 1682, the city determined to relinquish its undertaking. ${ }^{2}$

During the eighteenth century state fire insurance was adopted in Saxony, Silesia, Brunswick, Norway, Hanover, and Württemberg. At the close of the century a municipal system was organized at Berlin; and similar institutions under municipal control are now to be found in Hamburg, Breslau, Königsberg, Stettin, and Lübeck. Insurance is obligatory on all property owners, and the premium is dependent directly on the losses. So, too, in Zurich, Basel, and other Swiss cantons, the business of fire insurance is conducted directly by the cantonal government.

A few English municipalities have formed schemes for

1 Gomme, Principles of Local Government, p. 166.

2 Contemporary Review, LXVIII, 840. 
insuring municipal property from their own funds. The London school board has been its own insurance company in part since 1878, and for all its buildings since 1885; and Glasgow takes twenty per cent of its own risks. But in the main fire insurance in English-speaking countries is in the hands of private companies, under some state control.

\section{Fire Brigades}

Probably no town in any country has reached even the dimensions of a considerable village before some measures are taken to secure organized action in cases of fire, such as providing fire buckets and ladders. Later, volunteer fire companies are organized, at first entirely unofficial in character; but in time the municipality comes to provide apparatus, buildings, and other articles of equipment, so that the volunteer companies assume a semi-public character.

The early stages in the development of fire apparatus preceded the organization of municipal fire brigades. In the fifteenth century large water syringes were used to force water on fires, and in the sixteenth century syringes mounted on wheels came into use. Hand-pumping engines were invented in the seventeenth century, but were not employed in Paris until 1705. Leather hose was invented in Holland during the eighteenth century, and at the same time attempts were made to manufacture a serviceable fabric hose.

In the colonial towns of America the first measures for fire protection were the primitive requirements that householders should keep in readiness a certain number of ladders and buckets, enacted first about the middle of the seventeenth century. ${ }^{1}$ The first pumping engine in America seems to have been one ordered for Boston in 1702. Philadelphia secured one in 1718, and New York in 1731. These were hand engines, with a tank filled by buckets or stationary pumps; and not until about 1820 did suction engines

${ }^{1}$ Salem, 1644 ; Boston, 1654 ; New York, 1690 ; Philadelphia, 1696 ; Baltimore, 1747. 
appear. These early engines were frequently paid for by the municipality, but they were manned and operated by volunteer companies.

Paris took the lead in the development of an organized fire brigade. As early as 1716 a number of gardes pompes, to operate the fire pumps, were authorized; but it was not until 1811 that the permanent force of sapeurs pompiers was established and organized on a military basis. After 1830 brigades were established in several other large cities of Europe: at London in 1833, Milan in 1838, Madrid in 1843, Berlin in 1851, and Brussels in 1852. But all of these were poorly organized, with no adequate equipment and but a scant water supply.

Experiments with steam fire-engines became noticeable after 1830. In 1853 Cincinnati purchased one; and as the volunteer companies opposed this change in their methods, a paid force, one of the first in the country, was organized. Chicago and other Western cities at once followed the example of Cincinnati, and before long paid companies were organized in different cities throughout the United States. Baltimore adopted this method in 1858, Boston in 1860, New York in 1865, Detroit in 1867, Philadelphia in 1871, and St. Paul in 1881. About the same time important developments took place in European cities. The St. Petersburg fire brigade was organized in 1860, that of Vienna in 1864; and in 1865 the London brigade, which had been controlled by the insurance companies, was transferred to the Metropolitan Board of Works as a distinctly public force. In 1878 a permanent force was established in Glasgow.

Since 1870 there has been a steady extension of the system of paid, organized, and disciplined fire brigades throughout the civilized countries, but most of all in the American cities. A marked development in the apparatus and equipment has also taken place. Swinging harness to hasten the hitching of the horses to the fire wagons was first used at Allegheny and Louisville in 1870. In 1872 the first fireboat was built, for use in Boston harbor. Three years later 
a similar boat was secured for New York, and since then other cities located on bodies of water have purchased fireboats for use on the river, harbor, or lake front. The water tower was invented in 1876, and came into use in New York in 1880 and in Boston in 1882. The fire-alarm telegraph was introduced in 1876. Chemical engines were first used in Canada in 1883; and in 1886 these were introduced in Chicago, Milwaukee, Springfield (O.), and Lawrence.

The British towns have the least-developed fire brigades. Out of 420 brigades in the British National Fire Brigade Union, only 13 are entirely supported from public funds, 1 151 lack safety apparatus, and 234 have no steam fireengines, while one has an engine a century old. Liverpool has but 52 permanent firemen and 360 auxiliaries ; Manchester has a fire brigade of 100 men, Birmingham 61 men, and Leeds $35 .^{2}$

In the Latin countries the fire brigades are little better organized and equipped than those in Great Britain. Most of the French cities with over 100,000 population have small bodies of paid firemen with primitive apparatus; but Roubaix, and even Lyons, depend mainly on a force of paid call men, who receive 300 francs a year each. The larger Italian cities have a regular force of paid firemen; but Bologna, with 150,000 population, has a system of call men, paid only for actual service at fires. Rotterdam, Lisbon, Oporto, and Geneva still rely largely on volunteer companies.

German municipalities have as a rule larger and betterequipped fire brigades, as indicated by expenditure for their maintenance. Nine cities depend entirely upon a paid force, and Strassburg is the only city of over 100,000 without some drilled paid firemen. The Hamburg department is composed in part of call men; in Dresden, volunteer companies are used to some extent; and in Munich, Leipzig, and Cologne the volunteer companies are still the main reliance.

All of the capital cities of Europe have paid and disciplined fire departments. Those at Paris and St. Petersburg are as

1 Revue Générale d'Administration, LXV, 84 (1899).

2 Return, in Parliamentary Papers, 1899, vol. 83. 
large and as well equipped as the Berlin brigade. In Brussels and Amsterdam the brigades correspond closely in strength and equipment to those of German cities of the same population. Vienna and Madrid have less efficient organizations than Brussels or Paris, though better than those in the chief Italian cities. There are also paid departments at Antwerp, Ghent, Copenhagen, Stockholm, Christiania, Prague, Trieste, Warsaw, Riga; and in general cities in Teutonic lands are as well protected as those in Germany itself.

The greatest development of municipal fire brigades is found in the cities of the United States. In organization, in apparatus, in efficiency, and also in expense, the American fire departments are far beyond those of any other country. The widest variations in organization and equipment necessarily exist. For cities with less than 8000 population volunteer companies are almost universal. In cities with a population between 8000 and 30,000 , the prevalent system is a small number of men employed constantly, with a large number of call men; but there are still cities of this size with volunteer companies only, and there are also a number (84) whose entire force are regular full-time men. In cities with over 30,000 population, volunteer companies are only occasionally (in 10 cases out of 129) found to be an important element. In the states west of the Alleghanies, most cities with more than 30,000 inhabitants have the entire fire brigade composed of regular firemen; but in the Eastern cities having a population less than 100,000 call men, as a general rule, form an important part of the forces. Only 7 of 129 cities with over 30,000 population have no steam fire-engines; and in all these cities the water-works are operated on the Holly system, whereby the pumps of the waterworks furnish sufficient pressure for the use of firemen.

In the 38 cities of over 100,000 population, only Scranton, Penn., depends mainly on volunteers, while only San Francisco, Worcester, and Fall River have a considerable body of call men. Elsewhere in this class the permanent trained firemen are the main part of the brigade, and in most cases there are no other elements whatever. 
The New York city fire brigade, with 2400 regular firemen, 1000 horses, 195 fire-engines, 6 fire-boats, 129 hook and ladder trucks, and 400,000 feet of hose, is by far the largest force of any city in the world; but the Boston department, consisting of 730 men, 350 horses, 50 engines, and 21 hook and ladder trucks, is the strongest force in the world in proportion to population of the city. The Boston organization is fully as strong as that of Philadelphia, a city of more than twice its size. In proportion to population, the forces of New York and Chicago are stronger than those of Philadelphia and Baltimore, but less strong than that of St. Louis, and below the average strength. As a general rule, the smaller cities have a proportionately stronger force. Cities with unusually efficient fire departments are : Buffalo, Pittsburg, Detroit, Albany, Atlanta, Grand Rapids, Minneapolis, St. Paul, and Columbus. Baltimore, St. Joseph, Scranton, Reading, and Wilmington have weak fire brigades.

The brigade of Chicago has as many men and twice as many horses as that of London, a city three times the size of the American city, and has 98 steam engines and 4 hand engines, as compared with 60 steam and 25 hand engines in the British metropolis. Berlin, with fifty per cent more population than Philadelphia, has a force of men but a little larger, ${ }^{1}$ only one-fifth as many steam fire-engines, and as a counter-claim only 18 hand engines. Paris has as many firemen in proportion to population as Philadelphia, but only 17 steam fire-engines and 90 hand engines as compared with 46 steam engines in Philadelphia.

American fire departments composed of regular men are organized into engine companies and hook and ladder companies, usually consisting of not more than twelve men each. Certain companies (generally three engines and one hook and ladder truck) respond to a first alarm, and additional companies are called out by subsequent alarms if necessary. The foreman or captain of each company is responsible for the discipline of the men and the care of the apparatus, and is

${ }^{1}$ Berlin, 833 ; Philadelphia, 764. 
required to investigate the enforcement of laws for the prevention of fires within the company district.

In the larger cities the fire companies are grouped into battalions, each of which has a battalion chief, who takes command of the companies called out to fires of ordinary size. The battalions are grouped into larger sections, each under a deputy chief, who directs the force at more important fires; while the chief of the department has general control over the management and discipline of the entire uniformed force, and takes command in very serious conflagrations. $\mathrm{He}$ in turn is responsible to a civil commissioner, a board, or a council committee. New York, Philadelphia, and Boston have single commissioners; Cincinnati, Detroit, St. Paul, have boards ; the fire chief of Chicago has complete control under the mayor and council.

The control of the fire department is in almost every country a municipal matter, and only in France is there even any intensive control over the municipal authorities in this field. There the corps of sapeurs pompiers is attached to the ministry of the interior, the organization for each town is determined by the prefects, and the chief officers are appointed by the president of the republic on the nomination of the prefects. The men are recruited for five years and subjected to military discipline. The municipalities are, however, responsible for the maintenance of the force. At Paris the regiment of sapeurs pompiers acts under the appointed prefect of police, but is an integral part of the regular army under the minister of war as regards its organization and discipline. In a few other large cities - Berlin, Brunswick, Buenos Ayres, and Denver - the fire department is likewise under the central government. At Sydney, Melbourne, and Adelaide there are metropolitan fire districts including the territory of these cities and their suburbs, and the central governments as well as the various local authorities are represented on the fire commission.

Elsewhere municipal control of fire brigades is the almost universal rule. In Great Britain even the London brigade is under local direction, the County Council being the authority. 
In the United States the only exceptions are in Denver, Col., where the state-appointed police board also directs the fire brigade, and in San Francisco, where the fire-boats are owned by the state.

\section{HEALTH DEPARTMENT}

The preservation of the public health has been the subject of public action for centuries, and special organs for protecting public health - boards of health - were created several decades before the middle of the nineteenth century; but the recent development of medical and sanitary science has so altered the scope of public activity that the present system as it exists in the most advanced cities is distinctly and emphatically new.

Not to go further back, we may note that as early as the fourteenth century the Italian cities established quarantine measures for preventing the introduction of the plague. ${ }^{1}$ Similar measures were adopted in other countries; and at the beginning of the nineteenth century there were special provincial sanitary authorities in various parts of Italy and Germany. In 1802 a board of health (conseil de salubrité), consisting of four salaried members, was established in Paris. ${ }^{2}$ Between 1822 and 1832 similar boards were provided in the most important French towns: Lyons, Marseilles, Lille, Nantes, Troyes, Rouen, Bordeaux, Toulouse, and Versailles. In England the local improvement boards had some power to remove nuisances and unsanitary conditions; and in the United States local boards of health had been established in some cities - in New York (1805), Philadelphia (1818), and Chicago (1837). In no case, however, does there seem to have been any active or systematic work undertaken by such boards except during the presence of an epidemic of cholera or smallpox.

In 1847 Liverpool, under an act passed the previous year, appointed the first medical officer of health, the incumbent

1 Les Institutions Sanitaires en Italie, p. 5.

- Leroy-Beaulieu, L'administration locale, p. 260. 
being Dr. William Henry Duncan. The next year the city corporation of London appointed a medical officer of health (Dr. J. Simon), who gradually developed a methodical sanitary inspection of all the poorer parts of the city, resulting in periodical house-cleaning, street scavenging, general mitigation of nuisances, and the introduction of drainage and water supply. ${ }^{1}$

The cholera epidemic which ravaged Europe at this time (and reached America the next year) led to further sanitary legislation. In 1848 the Italian kingdom of Piedmont, France, and England all enacted laws providing for special health authorities. In the two first-named countries provincial or departmental boards were created, but no general measure was adopted in regard to municipal health officials. The English statute, however, besides creating a General Board of Health, authorized that central board to establish local boards wherever in their judgment the sanitary conditions required special action. Provision was also made for extending the system of paid medical officers of health, such as had been provided in Liverpool and in the city of London. Progress was slow for some time, and even as late as $\mathbf{1 8 7 2}$ only twenty-five urban authorities in England had provided a medical officer of health, and in only twentyone urban districts were there sanitary inspectors.

However, the legislation of 1871 , establishing the Local Government Board with increased powers, led to more active measures; and by the end of a decade 448 medical officers of health were reported, thirty of whom covered more than one urban district, so that in all 536 urban districts were represented. ${ }^{2}$ Since then the number of medical officers of health has steadily increased, until now practically every urban district has one. In this later period, however, the more significant facts have been the increased activity of these officials and the growth of their subordinate staff.

In London the public health is looked after both by the County Council and by the borough authorities. Each dis-

1 Simon, English Sanitary Institutions, p. 245.

2 Reports of Local Government Board. 
trict or municipal borough has a medical officer of health, with a corps of sanitary inspectors, who inspect houses, suppress and prevent nuisances, and enforce laws in regard to infectious diseases and overcrowded or unsanitary houses. Some boroughs also have a public analyst to detect adulterations in food and drugs. The health office for the administrative county of London was established in 1889, and exercises four distinct functions : that of court of appeals ; inspector of food supply; supervisor of lodging-houses, and inspector of infectious diseases. Householders may appeal to it in its first capacity when borough authorities fail to remedy unsanitary conditions. The duty of the County officer is to investigate such complaints of householders, and to communicate with the delinquent local official when necessary. As an inspector of food supplies, it is the duty of the County Council to license the private slaughter-houses (now numbering 429) and to deputize officers to inspect them. Cow sheds, dairies, and milk shops are also licensed, and all milk sellers must be registered. A staff of eight inspectors is employed to inspect the sanitary condition of these places. In 1895 the supervision of the common lodging-houses was transferred from the police to the County Council. Such houses must be registered and approved by one of the eleven inspectors in this department of the Council. As an inspector of infectious diseases, the jurisdiction of the County Council is limited to diseases which have spread over more than one district. ${ }^{1}$ The hospitals for infectious diseases are managed by the metropoli$\tan$ asylums board. The collection of vital statistics is made by the poor law guardians under the direction of the registrar-general - an official of the central government.

In Glasgow a medical officer of health was first appointed in 1862, and eight years later a sanitary inspector with a subordinate staff of forty-five officers was provided. This force was divided into squads for the inspection of lodging-houses, the investigation of infectious diseases, and the suppression of nuisances. Special fever hospitals were also pro-

1 The London Manual, 1899-1900, pp. 162, 163. 
vided at this time. The Act of $\mathbf{1 8 9 0}$ gave much additional authority to the health department, and its staff was largely increased. Under the present system there are three divisions : one for sanitary inspection, a second for disease inspection, and a third for disease treatment. Twenty-two of the 150 sanitary inspectors made, in 1895, 324,571 inspections and discovered 32,292 nuisances; eight lodging-house and "ticketed-house" 1 inspectors, enforcing the sanitary rules for lodging-houses charging less than sixpence per night, inspected 79 such houses with accommodations for 9372 persons. The regulations require 400 cubic feet of air for each adult, daily sweeping and airing, periodic cleansing, and water-closet facilities. In 1895 the number of sleepers was limited in 25,000 ticketed houses. In all 35,000 house inspections were made, and 3868 cases of overcrowding reported. Cases were reported where only 76 cubic feet of air (i.e. a bunk $3 \times 6 \times 4.25$ feet) was provided for each sleeper. The inspectors also investigate uninhabitable houses, test drains, and inspect shop hours and food supplies. There were four inspectors of bakehouses, dairies, and vegetable, fruit, and fish markets; three meat inspectors; and one analyst of food and drugs. It is the duty of inspectors for disease prevention to isolate patients in houses or hospitals, to disinfect places exposed to contagious or infectious diseases, to maintain sanitary wash-houses, ${ }^{2}$ and to vaccinate. For the treatment of diseases there are fever hospitals with accommodations for 980 patients. ${ }^{3}$ The following table gives Glasgow annual death rates per thousand population for four decades, showing the improvement since the health department has been at work :-

\begin{tabular}{c|c|c|c|c|c}
\hline Decade & Zymotics & Phthisis & $\begin{array}{c}\text { Other Lung } \\
\text { Diseases }\end{array}$ & Other Causes & All Causes \\
\hline $1855-1864$ & 7.8 & 3.9 & 5.2 & 13.1 & 30.0 \\
$1865-1874$ & 7.4 & 3.9 & 6.5 & 12.7 & 30.5 \\
$1875-1884$ & 5.1 & 3.4 & 6.3 & 12.1 & 26.9 \\
$1885-1894$ & 3.8 & 2.5 & 5.3 & 11.6 & 23.2 \\
\hline
\end{tabular}

1 A ticketed house is a three-room house with less than 2000 cubic feet of air, which is marked for periodic inspection to prevent overcrowding.

2 The first sanitary wash-house was established in 1864.

3 Bell and Paton, Municipal Glasgow, chs. 18-20. 
The Birmingham health department was reorganized in 1875. A medical officer of health was appointed, and the staff of inspectors was increased in number. The work of the department includes the inspection of houses and food, disinfection, and the establishment and maintenance of epidemic hospitals. From 20,000 to 30,000 nuisances a year have been abated, and 3000 wells have been condemned.1

An important part of the municipal health activity of English towns is the inspection and analysis of food to detect adulteration. The development of the middleman in modern trading seems to have greatly increased the amount of adulteration, and agitation on the subject in England led in $\mathbf{1 8 6 0}$ to the passage of an act authorizing local boards to appoint analysts. An act of 1872 made the appointment of analysts obligatory, and also provided for inspectors. Another parliamentary investigation led to the Foods and Drugs Adulterations Act of 1875, which, with some amendments, is the present law. ${ }^{2}$ Besides the analysts for the various district boards in the metropolis, about 140 boroughs have analysts (including all the county boroughs). In other urban districts the county analysts are relied upon. The total number of analyses made in England by both municipal and county analysts was 17,049 in $1879,26,594$ in 1889 , and 46,000 in $1897 .{ }^{3}$ The following table gives details of the analyses of food and drugs in 1897 :-

\begin{tabular}{l|c|c|c}
\hline \multicolumn{1}{c|}{ Locality } & Samples examined & Samples adulterated & $\begin{array}{c}\text { Per Cent } \\
\text { adulterated }\end{array}$ \\
\cline { 2 - 2 } Metropolis & 11120 & 1274 & 11.5 \\
Liverpool & 1172 & 178 & 15.2 \\
Manchester & 1703 & 49 & 2.9 \\
Birmingham & 1145 & 279 & 24.3 \\
Leeds & 238 & 28 & 11.3 \\
Sheffield & 223 & 23 & 10.3 \\
Bristol & 297 & 18 & 6.1 \\
Salford & 824 & 51 & 6.2 \\
Bradford & 264 & 24 & 9.1 \\
Cardiff & 594 & 23 & 3.9 \\
Swansea & 300 & 26 & 8.7 \\
\hline \hline
\end{tabular}

1 Shaw, Municipal Government in Great Britain, p. 185.

${ }^{2}$ Reference Handbook of Medical Science, III, 205.

8 Local Government Board Reports. 
In all England, 18,896 samples of milk were examined, and 10.4 per cent found to be adulterated. Of the 4700 samples examined in the Metropolis, 14.6 per cent were found to be adulterated. In 1892 the percentage of adulterated milk in London was 22.5 per cent. Coffee, spirits, butter, sugar, and drugs are the other articles most frequently adulterated; less frequently, but still adulterated to a considerable extent, are mustard, pepper, lard, confectionery, canned peas, and cocoa.

In France the hospitals for contagious diseases are conducted as a part of the general hospital system, and not by the sanitary bureau. Such bureaus are not so common as the medical officers of health in England, but they are to be found in the principal cities. The following table ${ }^{1}$ shows the number of officiers de santé in France in 1896 :-

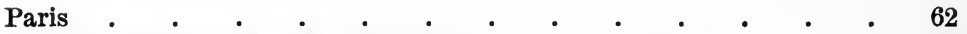

12 towns with over 100,000 population $\quad . \quad . \quad . \quad . \quad . \quad . \quad 32$

47 towns with population between 30,000 and 100,000 . . . $\quad$. 45

56 towns with population between 20,000 and 30,000 . $\quad . \quad$. $\quad 37$

134 towns with population between 10,000 and 20,000 . . . $\quad 27$

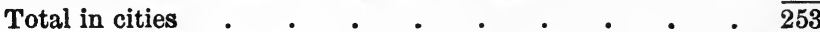

Communes

Grand total . $\quad . \quad$. $\quad . \quad$. $\quad . \quad$.

For twenty years the number has been steadily decreasing, as the following table ${ }^{1}$ will show :-

\begin{tabular}{c|c|c|c}
\hline \hline Year & $\begin{array}{c}\text { Number of Offciers } \\
\text { de Santé }\end{array}$ & Year & $\begin{array}{c}\text { Number of Officiers } \\
\text { de Santé }\end{array}$ \\
\hline 1876 & 3633 & 1891 & 2512 \\
1881 & 3209 & 1896 & 1605 \\
1886 & 2794 & & \\
\hline
\end{tabular}

Paris, Havre, Dijon, St. Étienne, Nantes, and Troyes have well-organized systems of food inspection and analyses. ${ }^{2}$ Havre, Rheims, St. Étienne, Nancy, and Nice have disinfec-

1 Annuaire Statistique, 1897, p. 511.

2 Encyclopédie d'Hygiène, VII, 806. 
tion bureaus in addition to the hospital facilities. ${ }^{1}$ A central health department was established at Nancy in 1879, at Havre in 1879, at Rheims in 1882, at St. Étienne in 1883, at Amiens in 1884, at Pau in 1885, at Nice in 1887, and at Toulouse in 1889. The department consists of various offcials, such as inspectors of unsanitary lodging-houses, vaccinators, medical school inspectors, veterinary surgeons for the supervision of abattoirs and markets, and analytical chemists for testing foods. ${ }^{2}$

The Paris Conseil d'Hygiène et de la Salubrite (board of health) dates from 1802. The prefect of police is president of the body; the other ex officio members, together with twenty-four life members, are specially appointed. It is an advisory board, meeting twice a month. Each arrondissement has a health board, consisting of the maire and nine members, which is also an inquiry and advisory board. As an auxiliary body, the sanitary bureau in the prefecture of police supervises the active administration of the health laws.

There is a highly developed system of meat inspection in Paris. In 1825 there were three inspectors of meat, but the number has been increased from time to time. In 1830 there were six meat inspectors, in 1855 fifteen, in 1879 (when the service was reorganized and enlarged) fiftyseven, in 1890 seventy. These inspectors make their examinations at the abattoirs, at the Halles Centrales located at the city gates, and at the retail markets throughout the city. ${ }^{8}$ The Paris municipal laboratory began active operations in 1881, replacing scientific tests for the former dégustateurs (tasters and smellers). In 1883 the laboratory force comprised one chief, one assistant, two principal chemists, twenty-three chemists, twenty-four expert inspectors, and a clerical force. The chemists and inspectors are selected by means of technical examinations. In addition to the analyses made of samples chosen by the inspectors, private citizens may

1 Encyclopédie d'Hygiène, IV, 801.

${ }^{2}$ Block, Dictionnaire de l'Administration française, p. 1293.

8 Encyclopédie d'Hygiène, VII, 806. 
submit samples (received and forwarded to the laboratory by the commissaries of police) on which a qualitative analysis and a report is made without charge, and a quantitative analysis upon payment of certain fees. ${ }^{1}$ The substances most frequently analyzed are wine, beer, cider, milk, butter, coffee, chocolate, and vinegar. In 1881, when the first analyses were made in the laboratory, fifty per cent of the milk samples were adulterated. In 1891 the percentage of adulterated samples was only ten per cent. ${ }^{2}$ The laboratory also makes water analyses, and furnishes scientific aid to the work of disinfection, and suggests improvements in the methods of sewage disposal and treatment.

The disinfection service in France has rapidly developed since 1884, both in the purification of infected houses and in the establishment of disinfecting stations for clothing and bedding. The epidemic hospitals are under the control of the charity administration. ${ }^{3}$

In Germany health regulations date from the Middle Ages, and central health authorities were established as early as the seventeenth century. In 1835 a Prussian law authorized the establishment of a board of health (Sanitätskommission) in each city of over 5000 population. The present laws on the adulteration of food and drugs date from 1872, and vaccination is required by an imperial law of 1874. There is now a hierarchy of health boards in the circles, districts, provinces, and the central government, with advisory powers. ${ }^{4}$ The active administration is in the hands of the police authorities, which have special bureaus for health work in the larger cities.

The most complete and efficient health departments in Germany are in Berlin and Hamburg. The Berlin Gesundheitsamt, an imperial institution, was established in 1870. The especial features of the existing system are: meat inspection at the public abattoirs; the disinfection bureau, established in 1886, with a staff of 79 persons, and stations

1 Block, Administration de Paris, pp. 621 ff.

2 Shaw, Continental Europe, p. 101.

3 Ibid., p. 94.

4 Stengel, Wörterbuch des Deutschen Verwaltungsrecht, II, 91. 
throughout the city; and the recently installed bacteriological laboratory. The Hamburg service has been greatly extended and improved since the cholera epidemic of 1892 . The staff in the disinfection bureau, consisting of 65 persons, is almost as large as that of Berlin. The sanitary regulations require the cleaning of beer houses and drinking dishes. Food and water inspection and a bacteriological laboratory also constitute a part of the Hamburg system; while the harbor sanitary police, for the inspection of vessels in port, is an additional service of importance. Elsewhere there are correspondingly efficient systems of food and water inspection. In all Germany, in 1878, there were 231,478 analyses made, and 3352 convictions for violations of the health laws. 1 Disinfection bureaus are found in most of the large cities; but only a few have a large staff in this service. Cologne has a force of 66 men, Weisbaden, 19, Charlottenberg, 18, and Bremen, 11.

In the United States most of the large cities had boards of health and health officers by 1850 , but before this date there was almost no permanent force, or constant service. The only diseases which as a general rule prompted action by municipal authorities or local boards of health were cholera and smallpox, and in general, too, no action was taken even in respect to these until the pestilence was at hand. When cholera threatened a city, the authorities took precautions and established sanitary regulations, but with the abatement of the alarm the enforcement of the regulations was relaxed. In the case of smallpox, action was taken only after the disease had made its appearance. Even in $1860 \mathrm{New}$ York, where there was a small number of street inspectors and food inspectors, furnishes the only example of a permanent force.

The modern system of sanitary inspection had its beginning in the Metropolitan Board of Health (a state commission) established in $\mathbf{1 8 6 6}$ for New York, Brooklyn, and the vicinity. This board entirely reorganized the service there, and the work has since 1870 been carried on by municipal boards. In 1867 the Chicago Municipal Board of Health

${ }^{1}$ Reference Handbook of Medical Sciences, III, 205. 
reorganized its service after the plan of the New York system, and a sanitary superintendent and a force of twentysix inspectors were appointed.1 In 1872 the Boston Board of Health was reorganized, and began its new work with smallpox vaccination and the inspection of meat and fish, but without any body of inspectors. In addition to New York and Chicago, the only American city which had any force of inspectors in 1873 was New Orleans, where there were twelve. The health officer of Baltimore had four assistants, St. Louis two, and Cleveland one. ${ }^{2}$

At the present time nearly every city of over 10,000 population has a board of health or health officer appointed by the municipal authorities ; while most cities of over 200,000 population have a considerable body of sanitary inspectors and trained assistants. The duties required of the health department are of three general classes: 1 , precautionary or preventive steps ; 2 , the management and control of infectious diseases; and 3 , the collection of vital statistics.

\section{Precautionary Action}

Local Nuisances. - Among the principal and almost universal duties of local boards of health are the inspection and abatement of unsanitary conditions liable to prove detrimental to the health, comfort, and convenience of citizens. To perform these duties the local boards usually possess arbitrary and summary powers, which have been upheld by the courts. "Their action is intended to be prompt and summary. They are clothed with extraordinary powers for the protection of the community from noxious influences affecting life and health, and it is important that their proceedings should be delayed as little as possible. Delay might defeat all beneficial results; and the necessity of the case and the importance of public interests at stake justify prompt action." 3

This general authority to suppress nuisances has developed to a marked degree along certain specific lines. It generally includes a special supervision over the removal of garbage

1 Report of Chicago Board of Health, 1867-1869, p. 121.

2 Reports of American Public Health Association, I, 506.

8 Opinion of a supreme court judge, quoted in Abbott, Public Hygiene, p. 48. 
and waste (including street cleaning). In some cities, where this work is undertaken by the municipality, it is performed by subordinates of the health department; but when performed by another city department, or by householders, the work is subject to the control of the health authorities. Another special line of control is that exercised over plumbing and house drainage, secured not only by regulations to be followed in building construction, but by the examination and licensing of plumbers. A further field of control is that over smoke. New York city prohibits the use of soft coal within its limits; other cities (e.g. Chicago and Cincinnati) require the use of "smoke consumers." Recently regulations forbidding spitting in public places have been enforced, to aid in preventing the spread of tuberculosis. Most cities of over 30,000 population have a staff of sanitary inspectors for these duties, and in cities of over 200,000 there is usually a considerable force. New York has 353 inspectors; Chicago, 40 ; Philadelphia, 44 ; St. Louis, 35 ; Boston, 19 ; Baltimore, 12; Cleveland, 26, and Cincinnati, 25. Cities more poorly equipped are Buffalo, with 5 inspectors; Milwaukee, with 8; Jersey City, with 6 ; and Louisville, with $3 . \quad$ A few cities with less than 200,000 population have an adequate service: Kansas City has 10 inspectors, Denver has 12, Memphis has 13, and Grand Rapids has $9 .^{1}$

In New York city the sanitary inspection covers the inspection of offensive trades, all public places, dwellings (with especial reference to drainage), removal of garbage, and the supply of water, light, air, and heat. In 1898 the force of sanitary inspectors made 158,045 inspections, and the sanitary police, 336,820. Complaints were made by private citizens to the number of 33,439 , of which 55 per cent were found warranted. Including the nuisances reported on the regular inspections, the total number of official complaints was 47,273 , of which 31,587 were made by the sanitary inspectors, and 15,686 by the sanitary police. This work included also the removal of dead animals, and during the year 78,057 cats and dogs were removed, and 12,870

1 Statistics of Cities : Bulletin of Department of Labor, September, 1900. 
horses. In Boston 11,271 horses, and in St. Paul 315 dead animals of all kinds, were removed. In Cincinnati 8702 nuisances were reported; in St. Paul, 14,272 ; and in Detroit, 19,298. In Detroit the plumbing inspections numbered 6273 .

Inspection of Food and Offensive Trades. - The large cities have milk inspectors, who examine the milk offered for sale, have power to make complaints against sellers of impure milk, and sometimes revoke licenses for cause. In some cities there are also special inspectors of animals, provisions, markets, and dairies. Several states have enacted general laws prohibiting food adulteration, and these are enforced by state authorities. Examples of such laws are to be found in the statutes of New York (passed in 1881), Massachusetts (passed in 1882), New Jersey, and Ohio.

Offensive trades are likewise sometimes under special supervision of municipal health departments. The most important trades of this kind are slaughter-houses, fertilizer, glue, and soap factories, tripe-boiling establishments, chemical works, stables, and gas-works. "Most cities of over 50,000 population have one or two milk inspectors; but only a few cities have even a small staff for the inspection of other food supplies and of offensive trades. New York has 50 inspectors for these latter purposes; Chicago, 15; San Francisco, 11; New Orleans, 14; Cincinnati, 7; Milwaukee, 8. The division of food inspection and offensive trades in the New York Health Department in 1898 made over 1,000,000 inspections, condemned nearly 10,000,000 pounds of food supplies, and made 4205 chemical analyses. ${ }^{1}$

1 Inspections made and Supplies condemned in New York

\begin{tabular}{|c|c|c|c|c|}
\hline Items & & Inspections made & $\begin{array}{l}\text { Quantity condemned } \\
\text { (Pounds) }\end{array}$ & Analyses made \\
\hline $\begin{array}{l}\text { Milk } \\
\text { Fruit and food } \\
\text { Meat and fish } \\
\text { Water . } \\
\text { Cows . } \\
\text { Offensive trades }\end{array}$ & 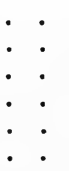 & $\begin{array}{r}106,778 \\
519,661 \\
399,938 \\
\\
14,657 \\
35,632 \\
\end{array}$ & $\begin{array}{r}258 \\
7,746,959 \\
860,963\end{array}$ & $\begin{array}{r}1,090 \\
2,735 \\
\\
380\end{array}$ \\
\hline Total . . & . & $1,076,666$ & $9,607,180$ & 4,205 \\
\hline
\end{tabular}


In 1898 the Boston Health Department examined 54,138 animals, 13,273 samples of milk, 719 samples of butter and oleomargarine, and 1039 samples of vinegar and cider vinegar; condemned 42 animals, with an aggregate weight of 11,086 pounds, and 21,390 pounds of provisions; and prosecuted 186 dealers in milk, 24 dealers in butter and oleomargarine, and 28 dealers in vinegar and cider vinegar. The Detroit Health Department examined 3288 samples of milk and 1943 of food-stuffs, and condemned 338,810 pounds of meat and fish. The St. Paul Health Department made 3708 inspections of meat, and condemned 27,685 pounds.

Vaccination. - Laws in regard to vaccination are found from the beginning of the nineteenth century. The practice is not so general in the United States as in Germany, where all children over two years of age are inoculated. The most effective American regulation is one preventing unvaccinated children from attending schools. In New York City 25,831 primary school children were vaccinated in 1898, and 33,366 secondary school children - in all, 59,197. The same year 3282 persons were vaccinated in Boston.

\section{Management and Control of Infectious Diseases}

Discovery, Isolation, and Disinfection. - Before 1880 smallpox was the only disease which was specifically required to be reported. At present, however, in cities and throughout densely populated states, all cases of smallpox, diphtheria, scarlet fever, and typhoid fever must be reported promptly. Other diseases less frequently requiring notification are measles, cerebro-spinal meningitis, yellow fever, leprosy, Asiatic cholera (which has not been epidemic in the United States since 1873), whooping cough, and German measles. Tuberculosis, although recognized as infectious, is required to be reported only in New York city.

The following statistics are for the period 1894-1898, and are compiled from reports from six states (Massachusetts, Michigan, Rhode Island, Vermont, Connecticut, and Indiana) and from large cities in other states :- 


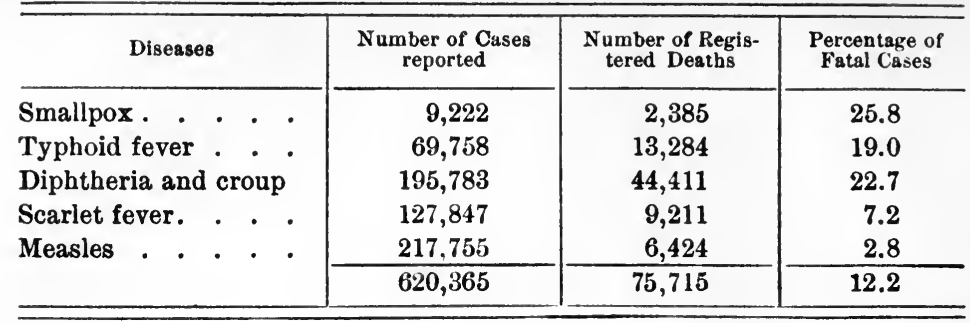

To assist in the discovery of cases of infectious diseases, a few large cities have special medical inspectors to examine doubtful cases, and also to examine children in public schools. In 1898 the medical sanitary inspector of New York city made 75,728 inspections. In New York 139,965 children were examined, and 7606 were excluded; in Boston 50,991 children were examined, and 7896 were excluded.

To guard against the introduction of infectious diseases from abroad, quarantine officers are established at ports, and it is their duty to examine all incoming ships, and upon the discovery of cases of infectious disease, to take proper steps for their isolation, and for the disinfection of exposed persons, baggage, clothing, etc. In New York the quarantine officer is a state official ; in New Orleans the state board, which acts as the municipal board of health, has control; and in Boston and Baltimore the quarantine officers are appointed by the municipality.

Municipal laboratories exist only in a few of the largest of the American cities. The Boston laboratory was first opened in 1898. The following tables show the number of bacteriological tests made in six cities :-

\begin{tabular}{l|l|r|r|r|r}
\hline \multicolumn{1}{c|}{ Year } & Cities & $\begin{array}{c}\text { Diphtheria } \\
\text { Tests }\end{array}$ & $\begin{array}{c}\text { Tuberculosis } \\
\text { Tests }\end{array}$ & $\begin{array}{r}\text { Typhoid } \\
\text { Fever Tests }\end{array}$ & Total \\
\cline { 2 - 2 } 1898 & New York & 11,557 & 3,945 & 1,886 & 17,388 \\
1898 & Chicago & 780 & & 715 & 1,495 \\
1898 & Boston & 3,988 & & 122 & 4,110 \\
$1898-1899$ & Cincinnati & 466 & 95 & 20 & 581 \\
1898 & St. Paul & 1,621 & 339 & 278 & 2,238 \\
$1898-1899$ & Detroit & 449 & 87 & & 536 \\
\hline
\end{tabular}


Chemical analyses made in the same cities were as follows :-

\begin{tabular}{l|r|r|r|r|r}
\hline \multirow{1}{*}{ Cities } & \multicolumn{4}{|c|}{ Analyses of } & \multicolumn{1}{c}{ Total } \\
\cline { 2 - 5 } & Milk & Meats & Water & $\begin{array}{r}\text { Other } \\
\text { Substances }\end{array}$ & \\
\hline New York & 1,090 & & 380 & 2,735 & 4,205 \\
Chicago & 19,296 & & 1,256 & & 20,552 \\
Cincinnati & 212 & & & & 212 \\
St. Paul & 17 & 587 & 81 & 34 & 719 \\
Boston & 13,273 & & & 1,758 & 15,031 \\
Detroit & 1,119 & & 20 & & 1,139 \\
\hline
\end{tabular}

The methods of disinfection employed in America are much the same as those in Europe. Apparatus for the steam disinfection of movable material is frequently found in hospitals and sanitariums. For the disinfection of closed apartments, formaldehyde has within the last three years largely superseded sulphurous acid. ${ }^{1}$ Seventeen thousand four hundred and ninety-two inspections have been made by the disinfecting corps of the New York board of health. In Boston 3360 premises, including 6939 rooms, were disinfected.

Treatment of Infectious Diseases. - Hospitals for the treatment of infectious diseases are not so general in the United States as in Great Britain, where most of the large cities have special establishments. Smallpox hospitals have existed here from an early period; but as the disease occurs only at irregular intervals, and the hospitals are consequently closed much of the time, their equipment has usually been primitive, and popular distrust is shown by the prevalence of the name "pest-house." Within the past five or ten years special provisions have been made in some of the larger cities. Fifteen of the sixty-two largest cities now have facilities for treating infectious diseases. New York city has four hospitals, which in 1898 treated 3013 cases. Infec-

1 S. W. Abbott, Public Hygiene, pp. 26-27. 
tious diseases hospitals are also to be found in Chicago, Boston, Paterson, and Worcester. Isolation hospitals for persons suffering with tuberculosis are less common, and those in existence are usually managed by private parties or corporations.

\section{Vital Statistics}

Vital statistics include statistics of births, marriages, and deaths, of which the last is the most important. Detailed and classified information relative to the deaths in different localities, at different ages, due to different causes, and in different races of people, helps to locate the great leaks of human life, and to indicate the proper place for the application of remedies. Such statistics are also valuable as tests of the efficiency of health administration. Some foreign countries have well-developed systems for the collection of vital statistics; but in the United States the only attempts made for the country at large have been made by the decennial national census since 1860, and these statistics have been incomplete on account of the absence of local data. Ten states (including the six New England states, and New York, New Jersey, Delaware, and Michigan) have fairly complete statistics for recent years. In other states systematic work is to be found only in the cities, and even here the birth and marriage statistics are generally very deficient, and often the death statistics, too, are far from complete.

From the records of some cities, where fairly complete records have been kept for a number of years, it is possible to show the results of recent sanitary and health regulations; and late statistics, which are available for a large number of cities, will indicate where there is the greatest need for further improvement. Thus the statistics collected by the Department of Labor show a high death rate from typhoid fever in Philadelphia, Pittsburg, Allegheny, and Louisville, which is good evidence that the water supply in those cities is not free from contamination. ${ }^{1}$ 
VITAL STATISTICS 1

New York City: Borovghs of Manhattan and the Bronx

\begin{tabular}{|c|c|c|c|c|c|c|}
\hline \multirow{2}{*}{ Year } & \multicolumn{5}{|c|}{ Number of Deaths from } & \multirow{2}{*}{$\begin{array}{c}\text { Total } \\
\text { Deaths }\end{array}$} \\
\hline & Smalipox & $\begin{array}{l}\text { Scarlet } \\
\text { Fever }\end{array}$ & $\begin{array}{l}\text { Typhoid } \\
\text { Fever }\end{array}$ & $\begin{array}{l}\text { Diarrhœeal } \\
\text { Diseases }\end{array}$ & $\begin{array}{l}\text { Diph- } \\
\text { theria }\end{array}$ & \\
\hline $1863-1865$ & 1,146 & & 1,685 & & & \\
\hline $1868-1872$ & 2,256 & 4,583 & 1,766 & 19,777 & 1,597 & 136,854 \\
\hline $1873-1877$ & 2,210 & 4,312 & 1,662 & 18,743 & 7,846 & 143,875 \\
\hline $1878-1882$ & 768 & 7,224 & 2,071 & 18,177 & 6,842 & 163,835 \\
\hline $1883-1887$ & 168 & 2,871 & 2,360 & 17,759 & 7,318 & 181,011 \\
\hline 1888-1892 & 167 & 5,208 & 1,897 & 17,672 & 7,659 & 207,945 \\
\hline $1893-1897$ & 291 & 2,462 & 1,625 & 14,937 & 8,894 & 209,560 \\
\hline
\end{tabular}

Cincinnati

\begin{tabular}{c|c|c|c|c}
\hline \multirow{2}{*}{ Year } & \multicolumn{3}{|c|}{ Number of Deaths from } & \\
\cline { 2 - 3 } & Scarlet Fever & Typhoid Fever & Diphtheria & Death Rate \\
\cline { 2 - 3 } & 410 & 136 & 72 & 21.70 \\
1873 & 546 & 91 & 152 & 18.89 \\
1879 & 134 & 178 & 103 & 18.49 \\
1890 & 17 & 205 & 414 & 19.81 \\
1899 & 13 & 121 & 65 & 18.41 \\
\hline
\end{tabular}

\section{Boston}

\begin{tabular}{c|c|c|c|c}
\hline \hline \multirow{2}{*}{ Year } & \multicolumn{4}{|c}{ Percentage of Deaths from } \\
\cline { 2 - 5 } & Smallpox & Scarlet Fever & Typhoid Fever & Typhus Fever \\
\hline $1841-1845$ & 3.64 & 14.99 & & 6.92 \\
$1846-1850$ & 5.47 & 11.41 & & 19.40 \\
$1851-1855$ & 4.39 & 9.11 & & 3.02 \\
$1856-1860$ & 4.70 & 14.23 & 4.80 & 0.22 \\
$1861-1865$ & 2.78 & 8.99 & 5.83 & 0.58 \\
$1866-1870$ & 2.10 & 9.80 & 5.26 & 0.18 \\
$1871-1875$ & 7.05 & 10.84 & 7.09 & \\
$1876-1880$ & 0.04 & 4.58 & 3.92 & \\
$1881-1885$ & 0.09 & 3.62 & 5.19 & \\
$1886-1890$ & 0.02 & 1.91 & 3.91 & \\
$1891-1895$ & 0.14 & 3.68 & 3.11 & \\
1898 & & 0.60 & 3.40 & \\
1899 & & 0.66 & 1.48 & \\
\hline
\end{tabular}

1 From Reports of Boards of Health. 
The central authority of municipal health departments is usually a board, with a health officer as the executive agent. This system is practically universal in the smaller cities, and is found also in New York, Philadelphia, Boston, and Buffalo. In the New York board, consisting of five members, the health officer of the port and the police commissioner are $e x$ officio members; the Philadelphia board, also consisting of five members, includes as an ex officio member the director of public safety; and in Buffalo the chairman of the board of public works and the mayor constitute two ex officio members of the three members of the board of health. The Boston board of health is likewise composed of but three members. In several large cities the single head system is followed in this department. In Chicago, Baltimore, Cleveland, and Cincinnati there is a single health officer. In some cities, however, not even all of the health officials are under a single direction. In Boston plumbing is under the supervision of the building department; in Buffalo and St. Louis the supervision of plumbing is independent of both the building and the health departments; in Cincinnati the smoke inspector is independent of other authorities. Baltimore has a special inspector of bakeries, while elsewhere bakeries are inspected by the state factory inspectors.

Instances of state officials conducting the direct administration of municipal health departments are rare. The state commission for New York lasted only from 1866 to 1870. New Orleans has a state board acting as a municipal authority; the Detroit board of health is appointed by the governor; and in Paris the health officials are under the direction of the centrally appointed prefect of police. Elsewhere the health authorities are locally chosen. A general supervision over local health departments, however, is exercised by a central authority in all the principal countries. In France and Prussia the central board of health is one of the bureaus in the ministry of the interior. In England one of the leading functions of the Local Government Board is to secure the enforcement of public health laws by local authorities. In the United States there are state boards of health in most 
states, with original authority in certain matters and a general supervision over local officials. The first state board of health organized was that of Louisiana in 1855. Massachusetts established one in 1869, California in 1870, Virginia and Minnesota in 1872, and Michigan in 1873. By 1896 such boards were to be found in thirty-two states; and to-day the only states without a board of health are Texas, Wyoming, Montana, and Idaho.

\section{BUILDING DEPARTMENTS}

Building regulations have in general four objects in view : 1 , protection from fire ; 2 , stability of construction ; 3 , sanitary conditions; and 4, the satisfaction of æsthetic taste. The building regulations to diminish the danger of fires are usually the most exacting, and constitute a most important means of guarding against such danger. The requirement that within the "fire limits" the external structure of all buildings shall not be of wood, but of some fire-proof material, is the most general. To this are added in many cities rules requiring fire-proof materials in the internal construction, the provision of fire-escapes and fire-proof elevators, the careful insulation of electric wires, gas fixtures, boilers, and other furnishings likely to produce fire, the construction of internal fire walls to limit the progress of fire, and the provision in very tall buildings of auxiliary fire apparatus, such as stand-pipes and hand chemical extinguishers. The regulations usually apply only to a limited section of the city known as the "fire limits," and including the compactly built district. Within these limits different regulations may be made for different classes of buildings, and the requirements vary from city to city.

In Europe wood is much less used as a building material than in the United States, partly because it is almost as expensive as fire-proof materials. In American cities wood is plentiful and cheap, and formed the material for most of the early structures. For a long time there were no building laws in American cities; but the great fire in Chicago in 1871, and that in Boston the following year, in combination with 
the higher insurance rates which followed, led to ordinances regulating building construction. Since 1887 revised building laws have been enacted in all the largest American cities.

The most rigid requirements are made for buildings of a public character, and for the huge buildings in large cities which are occupied by so many persons as to acquire a public character. Thus in New York, every building to be used as a hotel, lodging-house, school, theatre, jail, police station, hospital, or asylum exceeding 35 feet in height, and all other buildings over 75 feet in height, must be "fire-proof"; woodwork is allowed only for doors and windows, the frames for the same, floor boards and sleepers (the space between the floor sleepers being filled with fire-proof material). In buildings over 150 feet in height, even these parts must be of fire-proof material. Detailed regulations are also made to insure the complete stability of buildings in foundation, walls, piers, partitions, floors, girders, and internal structure.

Building regulations to prevent unsanitary conditions take two main directions. In the first place, there are the regulations to insure sanitary plumbing and connections with the sewerage system. Such regulations are to be found almost as frequently as any other form of building rules. The second class of these regulations are to aid in securing an ample supply of light and air.

In the largest cities the pressure of population has led to the construction of buildings so crowded together that it has been found necessary to insist by law upon certain minimum provisions for light and air in tenement houses. The system of tall tenements with no back yard space became a serious evil, first, in the large industrial cities which developed rapidly during the first half of the nineteenth century. Liverpool and Glasgow led the way in enacting preventive measures, and regulations of this sort are now to be found in most British cities. In London and Liverpool the building rules limit the height of the dwelling-houses to the width of the street, and require in the rear a courtyard, which also must equal in width the height of the building. ${ }^{1}$

1 Builder, November 30, 1895. 
The principal cities in continental Europe also have similar regulations. Those of Paris fix the maximum height of the buildings at 91 feet, while the height of buildings on streets less than 65 feet in width is limited to a figure below this. Rear courts must have a mean breadth of 16 feet, and if the building is over 60 feet in height, a mean breadth of over 20 feet. Interior courts or light shafts must be at least 6 feet in breadth and 100 square feet in area. ${ }^{1}$ The construction of chimneys in Paris is also regulated by law. The new building code of Berlin adopted in 1888 requires that one-third of each lot shall be left unbuilt on, and also fixes minimum limits for the cubic capacity of each room. ${ }^{2}$ In Rome the rules adopted in 1887 limit the height of tenements to one and one-half times the width of the street, with a maximum of 80 feet; the width of inner and rear courts must be not less than one-third the height of the building, and the minimum height is fixed for the ceilings of rooms. ${ }^{3}$

In most American cities the evils of overcrowding are not yet serious. Land has been so cheap that buildings have been spread over a large area, while even in the large cities the local rapid transit systems have aided in preventing too great a concentration of population. But in some of the older cities in the Eastern states the housing problem is a matter of importance; while in New York the situation for the last fifty years has been comparable to that in the most congested cities of Europe, and the building rules before 1901 were more lax in requiring light and air space than those of any other city where such regulations are necessary. There were no limits on the height of a tenement of "fireproof" construction; if the two lower floors only had fireproof construction, only five stories above the ground were allowed. Such buildings were permitted to cover from 75 to 80 per cent of a lot; and on the ordinary lot of 25 by 100 feet this condition was met by leaving a court 10 feet wide in the rear, and narrow strips or shafts $2 \frac{1}{2}$ feet wide by 50 feet in length on either side of the building. A new tenement.

1 Block, Dictionnaire de l'Administration.

2 Shaw, Continental Europe, p. 358.

Ibid., p. 281. 
house law passed by the state legislature in 1901 imposes better standards for future building.

For the enforcement of these various restrictions there is in the large cities a building department with an administrative force of architects and inspectors. Builders are required to submit for approval plans of proposed building construction and alterations, while inspectors visit buildings in process of construction to see that the requirements are obeyed.

The Boston Building Department comprises inspectors of construction and alterations, of boilers and engines, of plumbing and gas-fitting (these inspectors are also the licensing authority for plumbers and gas-fitters), of elevator construction, and of fire escapes and other means of egress. There are also an inspector of lime and an inspector of petroleum and its products. St. Louis, in addition to the building department, has an inspector of boilers and a board of engineer examiners; Chicago has inspectors of oils, of steam boilers, and of gas meters; Cleveland and Detroit have inspectors of boilers ; Cincinnati and Buffalo have each inspectors for the examination of engineers, and Buffalo has also an inspector of boilers and an inspector of oils.

Many European cities have not been content with regulating the construction of future buildings, but have taken active steps to remedy the previous conditions of overcrowding by carrying through improvement schemes involving the destruction of unsanitary dwellings and the reconstruction of considerable areas. The first important work of this kind was begun in Glasgow as early as 1866 . In all an area of 88 acres, inhabited by 50,000 people, has been cleared. At first the intention of the improvement trust was to dispose of the lands after reconstructing street lines; but owing to a long period of stagnation in local real estate, about 1888 the construction of new tenements and dwellings on the municipal estates was begun on a considerable scale. All together there has been expended over $\$ 10,000,000$. The property of this kind now owned by the municipality is valued at $\$ 6,000,000$. Under an act of 1875 the city of 
Birmingham has carried through another large improvement plan, which involved the razing of four thousand overcrowded buildings covering an area of ninety acres. The total expenditure was about $\$ 8,500,000$, and the income from property now owned by the municipality is over $\$ 300,000$ a year. The Metropolitan Board of Works also cleared considerable areas, and sold the sites as soon as possible; but its successor, the London County Council, has adopted the policy followed in Glasgow and Birmingham of building and managing buildings in the cleared districts. The total expenditure in the metropolis for such work has been over $\$ 12,000,000$.

Many other British cities have undertaken less extensive improvement schemes, notably Liverpool, Manchester, Leeds, Edinburgh, and Dublin. On the Continent also, in connection with street improvements, considerable numbers of unsanitary dwellings have been removed. The work in Paris is the most important of these. In the oldest part of the city, between the Louvre and the Hotel de Ville, and also on the Isle de la Cité, thousands of ancient houses, huddled on narrow streets, have disappeared, and have been replaced by spacious streets and massive public edifices.

Even in New York city some of the worst sections have been cleared of unsanitary dwellings, partly by condemning the land for use as small parks, and partly by condemning some of the worst rear tenements as public nuisances. But the conditions there still call for radical action. The tenth ward of New York on the lower east side is the most densely crowded district in the world; and conditions there steadily grow worse, as shown in the following table :-

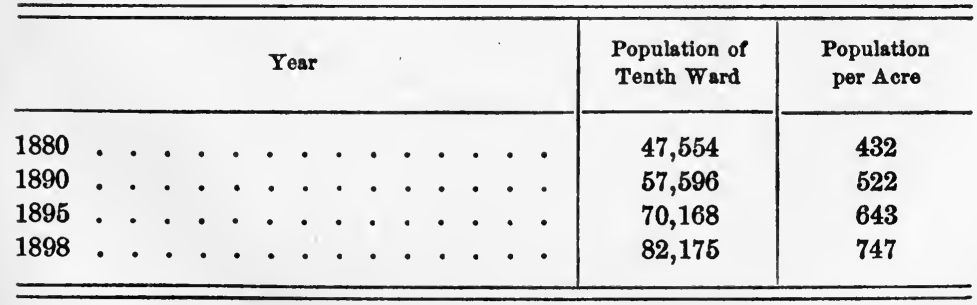


In particular blocks the population is at the rate of over 1700 to the acre. One block, ${ }^{1}$ by no means the worst, had in 1900 a population of 2781, of whom 466 were children. Four hundred and forty rooms in the block had no direct light, and 635 others were lighted only from air shafts. Conditions but slightly better are to be found in the more recently built-up sections on the west side and in Harlem. One large block between West Sixty-First and Sixty-Second streets had a population of over 4000 , and less than half of the rooms opened to the outer air.

\section{ECONOMIC REGULATION}

The great bulk both of regulation and administration governing the conduct of business from purely economic motives is now in the hands of the state and national governments. But there are still some municipal officials with powers in this department.

Most common is the sealer or inspector of weights and measures, to be found in every city of importance. In Cleveland this official is a subordinate to the director of police; but elsewhere he is subject only to the mayor or council. New York city has 10 inspectors and 10 sealers of weights and measures, and also 39 official weighing stations for coal. Baltimore has an inspector of weights and liquid measures, and another inspector of dry and long measures. Most cities, too, have one or more pound masters, by whom stray animals are impounded. The licensing of public carriages is usually done by the police department; but in New York this is the work of a special official known as the mayor's marshal. Inspectors of gas meters are also to be found in large cities.

The longest list of such officials is to be found in Boston, where there are, besides those previously mentioned, 2 weighers of beef, 15 weighers of boilers and heavy machinery, 63 weighers of coal, 27 measurers of grain, 16 inspectors of hay and straw, 8 superintendents of hay scales, 3 measurers of upper leather, 3 weighers and inspectors of vessels and ballast, 20 measurers of wood and bark, 2 fence viewers,

1 Bounded by Bayard, Canal, Christie, and Forsyth streets. 
and 5 field drivers. The police control department of the London County Council includes 17 inspectors of weights and measures, 5 coal-weighing inspectors, 8 gas meter inspectors, 11 veterinary inspectors, 9 shop hours inspectors, numerous bread inspectors, and inspectors who grant licenses for the sale of explosives, petroleum, acetylene, etc.

All the branches of municipal activity thus far considered are of a preventive or regulative character, as distinguished from the more positive and aggressive nature of municipal works, charities, and educational facilities. It is of interest to note some endeavors to recognize the distinctive nature of these regulative functions by a separate organization of the various authorities in this class, distinct from the organization for the entire mass of municipal activities. In Germany there is a recognition of the mutual relations of such functions in their treatises, which discuss them all as various branches of the "police." Although in France the legal and theoretical discussions of the police authority do not include in that term so much as they do in Germany, the actual scope of power possessed by the prefect of police in Paris, and the police power of maires in other French towns, corresponds closely to the regulative functions; while the municipal council has control only over public works and charities.

There are also a few instances in the United States where some organization is provided on this basis. The most complete organizations are those of Philadelphia and Pittsburg, where the director of public safety has under his general control the police, fire, building, and health departments. In Denver, Col. there is a single commission over the police and fire departments. In Cleveland the health officer is subject to the authority of the director of police, and in New York the police commissioner is a member of the board of health. Such official connection between departments whose affairs are interwoven at many points is advisable; and a single head for the consolidated offices, with single heads for each subordinate division, except possibly the health department, seems preferable to the board system. 


\section{CHAPTER IX}

\section{Charities and Provident Institutions}

Authorities.-T. W. Fowle: The Poor Law. - Homer Folks : Municipal Charities in the United States : Conference on Charities and Correction, 1898, p. 106. - Fleury RAvarin: De l'assistance communale en France, 1885. - Poor Laws in Foreign Countries : Reports to L. G. Board, 1875. - Municipal Affairs, III, 516. - Journal of the Royal Statistical Society, 61 : 271 : Poor Relief in Scotland, 1791-1891. - SHaw : Municipal Government in Continental Europe, 112-118, 366-374.

\section{POOR RELIEF AND HOSPITALS}

Public charity developed during the Middle Ages under ecclesiastical control. The monasteries and convents, with their monks and nuns, were distributers of relief, while endowed hospitals and homes for the aged were also under clerical management. During the period of the mediæval cities there was also some municipal action, but generally in the way of aid to existing institutions. From the middle of the sixteenth century, however, there was an increase in secular activity, and a comparative decline in ecclesiastical administration - at first in the countries where the Protestant movement was successful, but extending later to Catholic countries. During the nineteenth century there has been a general revision of charity laws, a vast increase in the amount of public charitable work, and a steady development of municipal action, aided in some countries by the central government.

England was the first country to establish a definite system of public poor relief. The suppression of the monasteries by Henry VIII, at a time when economic changes were increasing the number of the poor, forced the question to the front; and a series of parliamentary statutes, beginning 
in 1536, culminated in the Elizabethan Poor Law of 1601. This made the relief of the poor an obligatory duty on each parish, and provided for the election of local officers with power to levy taxes and authorized to distribute relief.

In Germany as early as 1497 there was an imperial ordinance against begging and vagrancy; while in 1552 poor relief was declared to be a communal function; ${ }^{1}$ and, although no general system of officers and local taxation was provided, as in England, in many towns communal authorities were appointed.

A century after these measures had begun in England and Germany, municipal action began in France, in the time of Louis XIV; but this was on a different basis from that of either the English or German systems. In 1656 the various charitable institutions in Paris were united under a single semi-official administrative management. During the next few years a similar centralization was effected in the other large cities; and finally, in 1698, a general regulation provided for an identical system of charitable management in each town, - the maire, the curé, and the seigneurial judge being each on the board of managers. The institutions continued to be mainly supported by the income from endowment, and in practice the clergy continued to dominate the charity administration. ${ }^{2}$ During the seventeenth century bureaus of charity had also been established in several French cities, which supplemented the work of the hospitals and asylums with some outdoor relief; but these bureaus also depended on gifts and endowments, and were under ecclesiastical control. ${ }^{3}$ The French Constitutional Assembly in 1793 confiscated the property of the charitable institutions, and attempted to establish a centralized system of poor relief. The attempt failed, and in 1797 the endowments of the hospitals and asylums were restored, and provision was made for an extension of outdoor relief through bureaux de bienfaisance. Communal grants in aid of either form of charity

1 Reports to Local Government Board, 1875, p. 25.

2 Ravarin, De l'assistance communale en France, pp. 26, 27.

${ }^{3}$ Ibid., p. 186. 
were authorized, while the administrative management was altered so as to remove the ecclesiastical element.

Meanwhile, during the latter part of the eighteenth century, conditions in England were making the problems of poor relief in that country much more serious than formerly, while the situation continued to grow steadily worse until the reorganization of the system in 1834. The causes of this situation were twofold: On the one hand were economic disturbances, caused by the industrial revolution, the long war with France, and the stagnation of trade when peace was restored. On the other hand, not only was there little or no improvement in the methods introduced to meet the new conditions, but changes in administration were made which added to the necessary burden of relief, and even promoted and encouraged pauperism. In 1776 the total amount of public relief had been $£ 1,529,780$; in 1783 it had increased to $£ 2,004,238$; by 1803 the latter figure had more than doubled ( $£ 4,267,965)$; and the progression continued until, in 1817 , it reached the maximum of $£ 7,870,801$, in a population of about 11,000,000. The Poor Law Amendment Act of 1834 divided the country into about 600 districts, called Poor Law Unions, which took the place of the 15,000 parishes, as the primary unit. Each union had a board of elected poor law guardians; while a central poor law board was established at London with radical powers for directing the whole system. Under the new régime the outlay for poor relief declined from $£ 7,036,969$ in 1832 to $£ 4,044,741$ in 1837. Since the latter date there has been a slow increase, due in part to the increase in population, and in part to the provisions for hospitals, asylums, and schools as a part of the relief system.

This historical sketch indicates the complications of municipal and other authorities in the work of public charity, and should sufficiently explain why it is necessary, in an account of municipal charities, to discuss non-municipal undertakings, and to describe, to some extent, the general system in each country.

The broad generalization may be made that in the Latin 
countries charitable work is mainly supported by endowments and private gifts, while in the Teutonic countries there is a much larger extent of public taxation and public administration. While the former system prevails in France, Italy, and Belgium, the administration of the endowed charities in each city remains under the control of a public trust, or board, which has a semi-official and, sometimes, a distinctly municipal character.

In France the system of charity administration, except that for special classes, is based on the municipal territory, but combines municipal and departmental control. Dependent children and insane persons are placed in departmental institutions. In somewhat less than half of the communes there is a bureau de bienfaisance for outdoor relief; while in the urban communities there are hospitals and homes under public management. ${ }^{1}$ The bureaux de bienfaisance and the hospitals in each city are usually controlled by separate unsalaried boards, each composed of the maire, two members chosen by the municipal council, and four members selected by the prefect of the department. In the larger cities the number of members is increased, but both municipality and department continue to be represented.

In Paris the arrangements are more complex. Both the management of hospitals and the supervision of outdoor relief are under the control of a single director, appointed by the minister of the interior on the nomination of the prefect of the Seine. In addition to this director there is a large advisory council $;^{2}$ and for the supervision of the distribution of outdoor relief there are also twenty arrondissement

1 In 1881 there were 1636 hospitals and asylums and 13,722 bureaux de bienfaisance. La Grande Encyclopédie, IV.

2 The central council is composed of the prefect of the Seinc (president), the prefect of police, two members each from the municipal council, the arrondissement maires, and the arrondissement bureaux de bienfaisance, one representative each from the Council of State, Court of Cassation, the doctors and the surgeons in the hospitals, the university faculty of medicine, the chamber of commerce, and the councils of prud'hommes, and five others. The appointments are made by the president of the republic on the nomination of the minister of the interior. 
bureaux de bienfaisance, composed of certain ex-officio and other unsalaried members. ${ }^{1}$

The total expenditure of the French hospitals and homes for the year 1897 was $\$ 27,750,000$, of which $\$ 10,800,000$ was expended by the institutions in Paris. The municipal grants amounted all together to about $\$ 5,000,000$, of which $\$ 3,100,000$ came from Paris. The total expenditure of all the bureaux de bienfaisance was $\$ 8,700,000$, of which $\$ 2,670,000$ was municipal subventions. The municipal funds are important only in the largest cities. In Paris the total municipal outlay for charities in 1898 was $\$ 5,900,000$; in Lyons, $\$ 270,000$; in Marseilles, $\$ 800,000$; and in Bordeaux, $\$ 227,000 .^{2}$ Municipal grants are not obligatory on the communes, except for dependent children; while the central authorities do not favor a permanent tax for poor relief.

In Belgium the municipal nature of the charity administration is more clearly defined. The members of the supervising boards are elected by the municipal council, and deficits on the budgets are regularly supplied from the municipal treasury. In Holland, however, charity work is mainly performed by private institutions and societies, and public aid is given only where it is necessary to supplement these - usually by means of small subsidies.

In the Italian cities the statute of 1862 provides for a charity commission (Congregazione di Carita) in each commune, and this commission has charge of hospitals and homes, and distributes outdoor relief. These boards consist generally of from four to eight members, sometimes chosen by the municipal council, but more often (as at Rome and Milan) they are autonomous authorities. In 1880 there were 17,870 charitable institutions in 5951 communes; 2431 communes had no charitable boards. The law requires the communes to furnish medical aid to the poor and to take part in the

1 These arrondissement boards are composed of the maire, adjoints, and municipal councillors of the arrondissement, and four members appointed by the prefect of the Seine. Block, Dictionnaire de l'Administration.

${ }^{2}$ Annuaire Statistique de la France, 1899, pp. 33, 42 ; Cadoux, Les Finances de Paris, p. 698. 
care of foundlings; and the budgets of the large cities show considerable amounts expended for charities, especially as grants to hospitals. ${ }^{1}$ The insane are cared for in provincial institutions.

An imperial law of 1870 now governs the system of poor relief throughout the German Empire, although this is supplemented by various statutes of the several states. Communal relief, as established in the sixteenth century, remains at the basis of the system; but larger districts, including several communes, are also provided for in the rural sections ; and there are provincial institutions for the insane, idiots, and deaf-mutes, and provincial poorhouses for paupers not chargeable to any particular commune or district. Each important German city has a distinctly municipal charity administration, which embraces outdoor relief, the management of homes for the aged and for destitute children, and hospitals (including hospitals for the insane in the larger cities); while the private charities are also united, in large measure, to the municipal service. At the head of this work in each city is one of the trained, salaried magistrates, with a committee of the council, each member of which has charge of a local district; while these are aided by large local committees of unpaid citizens. Thus, in Berlin there are about 250 of these local committees, each consisting of from 5 to 12 members. These committees act in two capacities, - as investigators and as distributers of outdoor relief. The total expenditure for charities in Berlin during 1898-1899 was $\$ 2,750,000$; in Munich, $\$ 300,000$; in Leipzig, $\$ 450,000$; and in Dresden, $\$ 370,000$.

In the United Kingdom the principal work of poor relief is under the control of local public authorities, who are, however, not only entirely independent of the borough government, but also are elected in districts whose boundaries are not conterminous with any other local districts. In Scotland each parish is still a poor relief district; but in England, Wales, and Ireland the primary unit is an area embracing a number of parishes, known as a poor law union. Each union

1 Naples, $\$ 90,000$; Milan, $\$ 80,000$; Genoa, $\$ 100,000$; Florence, $\$ 100,000$. 
consists of both urban and rural parishes, except in the largest cities. Local boards, comprising a large number of members, are elected in each district, and control the workhouses, the almshouses, and poor law schools; they also superintend the distribution of outdoor relief, which is much more extensive than in other countries. Practically, the entire revenue of these authorities is raised by taxation, and amounts to $\$ 50,000,000$ a year. The district authorities are under strict control by the Local Government Boards at London, Edinburgh, and Dublin. The insane, and other special classes, are cared for in county institutions; and in this field the county boroughs either maintain distinctly municipal institutions, or share in the expense and management (by a joint committee) with the council of the county.

The arrangements for charity distribution in London require special mention. The metropolis is divided into thirty poor law unions, in each of which there is elected a board of guardians. There are also six boards of managers of poor law school districts, and the Metropolitan Asylums Board, which has charge of the hospitals for the insane and for patients having infectious diseases. The last-named board consists of 55 members chosen by the boards of guardians, and 18 named by the Local Government Board. The total annual expenditure for public charities in London is about $\$ 17,000,000$, nearly $\$ 4.00$ per capita, and by far the largest proportionate expenditure for poor relief in any city of the world.

In the United States the earliest system of poor relief was based on the English parish system; and, in New England and the Middle states, poor relief was an important function of town government. But during the decade 1820-1830 a transition was made in New York State from the town system of outdoor relief to a system of county poorhouses. Since that time the county system has been adopted in most of the states except those in New England. Beginning about the middle of the nineteenth century, there has been a considerable development of state charitable institutions for special classes, as the insane, deaf and dumb, and blind. Since the 
close of the Civil War the pensions to ex-soldiers by the federal government have developed until they are now by far the most important item in the public charities. In 1890 out of a total of $\$ 147,000,000$ expended by all public charities, $\$ 107,000,000$ was for pensions by the federal government.

Throughout the United States there is the usual absence of uniformity in conducting the administration of state and local charities. In the states of New England and in New Jersey poor relief is a municipal function even in the smallest towns. Elsewhere the county is the general basis of the system; but most of the large cities, either by absorbing the county administration, or by special provisions, have control of public charity within their limits. Of the ten largest cities, public charities are municipal in eight, the exceptions being Chicago and Buffalo, where they are a county function. The municipality of Buffalo, however, gives large amounts to private institutions. Of the ten cities next largest in population, local public charities are under municipal control in five, and in the other five the general system is in the hands of the county authorities. All together, in about half of the cities of over 25,000 population, local poor relief is municipal, while a third of the others have some municipal expenditure for charities.

There are two distinct systems of administration. The unpaid board of from five to nine members is the survivor of the former overseers of the poor. Philadelphia has a board of five members; Boston has three boards for different phases of charity work, each of seven members; Baltimore has nine supervisors of charities; Cincinnati has six overseers of the poor; and Detroit has four poor commissioners. In San Francisco and Indianapolis the municipal charity administration is under the control of the same board which is at the head of the health department. Minneapolis has a board of charities and corrections. Where this system has been replaced by salaried officials the board system is, in almost every case, replaced by the single-headed department. The only important instances of salaried boards are at Columbus, 
O., and St. Paul, Minn.; in the latter case the members receive only a per diem allowance. New York has three salaried commissioners, each with independent jurisdiction in different boroughs. The St. Louis institutions are under the control of the health commissioner, although there is also a visitorial supervising board of four unpaid commissioners. Among other cities with a single salaried official for this department are Cleveland, Pittsburg, Washington, Allegheny, Syracuse, and Albany.

Outdoor relief from public funds is very limited in American cities, except in the form of medical assistance to the sick. The principal cities in which a considerable amount of other outdoor aid is regularly given are Chicago (Cook County), Boston, Buffalo, Detroit, and Milwaukee. Relief is most largely given through admission to almshouses and hospitals. New York city contributes about $\$ 3,000,000$ a year to private charitable institutions, mainly homes for destitute children. Philadelphia, Baltimore, Washington, and Albany each give from $\$ 70,000$ to $\$ 250,000$ to private institutions, and a number of smaller cities give much smaller amounts. ${ }^{1}$ Chicago (Cook County), Philadelphia, Boston, and St. Louis have municipal insane hospitals, and a few other cities care for some part of their insane; but, in general, this class, and also the deaf-mutes, blind, and feebleminded, are cared for in state institutions.

1 MUNiCipal GRANts to PRIVATE Charities, 1899

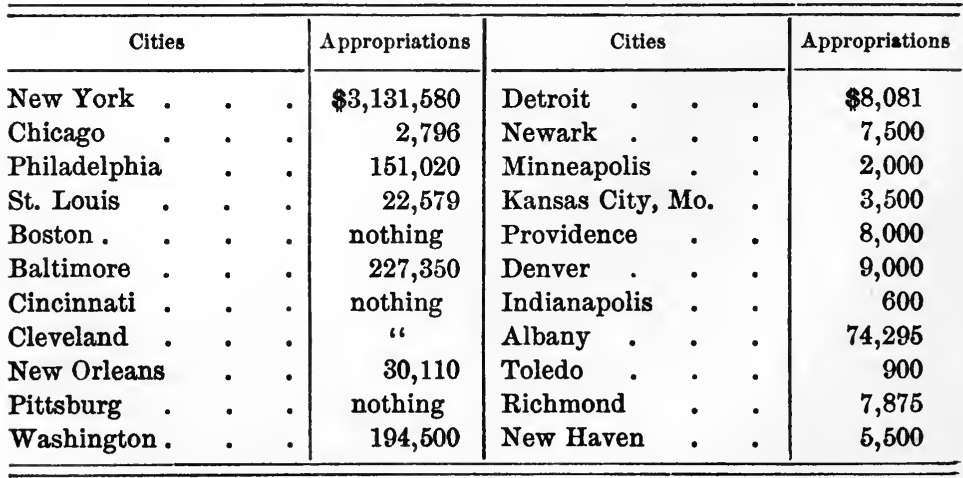


In addition to the various forms of public charity, there is a vast deal of private charity by churches and other voluntary philanthropic agencies. In order to provide a better organization, and to avoid extravagance and waste, there have been formed in each of the most important cities a Charity Organization Society, which, rather than any official organ, is the centre for all the charity work in the community.

The public charities of New York city include three almshouses and eight hospitals, with an aggregate value of $\$ 17,000,000$ and a capacity of 7500 inmates. The annual cost of operating these institutions is slightly less than $\$ 2,000,000$, and this amount added to the appropriations for private institutions makes a total of nearly $\$ 5,000,000$ a year spent by the city for charitable purposes. This does not include the sums spent by the state for the support of the city's unfortunates and indigent, maintained in state institutions, nor the large amount of private charity; and it is impossible even to estimate these items for New York city. The following estimate, made in 1896 , for the state of New York will, however, indicate roughly the relative importance of the different branches of charitable work:-

$$
\begin{aligned}
& \text { County poorhouses . . . . . . . . } \$ 1,515,000 \\
& \text { City almshouses . . • • • . . . } 1,649,000 \\
& \text { Municipal grants . . • . . . . . } 3,000,000 \\
& \text { Local charities . . . . . . . } \frac{.16,164,000}{6} \\
& \text { State institutions . . . . . . . . } 7,298,000 \\
& \text { Private charities . . . } \$ 14,000,000 \\
& \text { Less municipal grants } \cdot \quad \cdot \quad 3,000,000 \quad 11,000,000 \\
& \text { Total . . . . . . . . . } \$ 24,462,000
\end{aligned}
$$

Public charity in Cook County, Illinois, amounts to about $\$ 800,000$ a year, this including the cost of maintaining the hospital for the chronic insane as well as the other hospitals, outdoor aid, and small grants to private institutions.

\section{PROVIDENT INSTITUTIONS}

In addition to the direct aid furnished by the charity authorities and institutions, there are a number of municipal institutions, which, although often self-supporting, are dis- 
tinctly philanthropic in character, and aid, indirectly, in reducing the need for public charity.

\section{Employment Bureaus}

Most charity authorities and organizations make some attempt to secure employment for able-bodied persons without work; but the establishment of distinct official agencies for a systematic effort in this line is comparatively rare. More has been done in this line in German cities. than elsewhere. In 1897 there were seventeen of the German cities with over 50,000 population, with municipal employment offices, while in as many more cities there were central labor bureaus under the control of private philanthropic agencies receiving municipal support. The institutions under private control seem to be somewhat the more successful. During 1897 the Hamburg offices secured places for 38,000 , those at Berlin for 53,000, and those at Dresden for 21,000. Of the municipal institutions that at Munich found situations for nearly 30,000; Cologne 13,000, and Frankfort-on-the-Main 11,000.1

Similar institutions are maintained in most of the Paris arrondissements and in many of the large provincial cities of France: Marseilles, St. Étienne, Rouen, Rheims, and Nice. They are also to be found in other European cities, as, for example, at Brussels, Ghent, Geneva, Berne, Christiania, and Bergen.

In Great Britain public employment offices have been established by the Board of Trade in the large industrial centres, such as Liverpool, Glasgow, Sheffeld, and Salford. In some instances, too, the borough authorities have established temporary bureaus in times of special distress. But none of these British offices have the importance of those in the German cities. In America, employment offices have been established by the state labor bureaus in New York city, Chicago, San Francisco, and the five largest cities in Ohio. For the most part, however, this service is performed by the trade-unions for their members; while every impor-

1 Statistisches Jahrbuch Deutscher Städte, VIII, 120. 
tant city has a large number of private agencies, many of which are fraudulent and should be subject to police control.

\section{Allotments}

A very minor form of philanthropic endeavor has been the letting of small plots of land to the poorer classes for petty farming, often for nominal rentals. In Great Britain, Parliament has passed allotments acts to encourage this; but even there comparatively little has been done. The most important instance is that of Nottingham, where the municipality rents some 230 acres, in lots of about 600 square yards to 1500 persons. The local custom of small garden plots undoubtedly favors the municipal work in this case. There are allotment systems on a small scale at Paris and Berlin, and also in a few other German cities. During the industrial depression after 1893 several United States cities, notably Detroit and Buffalo, inaugurated something of the kind; but these attempts were soon abandoned.

\section{Public Loan Offices}

In many cities of Central and Western Europe there is a central pawnshop, or mont de piété, either under municipal management or with at least a semi-official position. The origin of these institutions dates from the latter part of the Middle Ages. There are records of a pawnshop regulated in the interest of borrowers at Fresingen, in Bavaria, as early as 1198, and at Salins, in Franche-Comté, in 1350. But these were isolated instances, and a general movement in this direction did not begin until the fifteenth century in Italy. In 1462 a monti di pieta was established at Perugia. Similar institutions were soon established in the other important Italian cities. $^{1}$ From Italy they spread, step by step, throughout continental Europe. In 1618 a superintendent of the monts de piété was appointed by the Archduke of the Austrian Netherlands, and a system of central control over the local institutions was established. The earliest institu-

1 A. Baize, Des Monts de Piété, I, 63-67. 
tions in France were at Avignon, in 1577; Arras, 1621; and Paris, 1777. These institutions were benevolent in character, to liberate the poor from the oppressions of usurers by furnishing loans at moderate rates of interest, and they were generally under ecclesiastical control.

At the time of the Revolution in France these institutions were suppressed as monopolies, and with the extension of the French dominion the prohibition was also applied in other countries. But the evils of usury and oppression, under unregulated pawnshops, soon asserted themselves; and before long the public institutions were reëstablished under official control, but without ecclesiastical control. During the nineteenth century the governments encouraged the development of these institutions, and they have become very general.

Municipal establishments of this kind are most frequent in Belgium and Holland. At least seventeen Belgian cities have monts de piété; and twenty-five Dutch cities and towns have banken van leening, including all the important cities in the two countries. In both countries the managing boards of these institutions are appointed by the municipal councils, and the capital is supplied from the municipal treasury and (in Belgium) from the charity bureaus. There is also in each country a system of central control over the local establishments.

The reports of the Belgian monts de piété for 1892 show that loans were made to almost 1,000,000 persons, aggregating $\$ 2,250,000$. More than half of the loans were for less than 5 francs, and only 4 per cent were for over 50 francs. The rate of interest varies in different cities, and in some places a sliding scale is used. The lowest rate is 5 per cent, and the maximum 16 per cent. The operations of the pawn banks in Holland are about on the same scale so far as the amount of money is concerned; but the number of pledges is from two to four times as large for the same amount of loans, showing a much smaller average loan.

There are 76 German cities, of over 15,000 population, with municipal pawn banks, and also a number of smaller cities. 
Thirty-six of the 55 cities of over 50,000 population have municipal loan offices. There are also in some cities, as Berlin, Brunswick, and the capitals of some of the small duchies, institutions under the control of the state government. The only important cities where there is neither a municipal nor a government loan house are Magdeburg and Bremen. But frequently there are also establishments under private control in addition to the public loan offices, and the transactions of the latter are comparatively of less importance than they are in the low countries. Thus in Berlin, for the year 1895-1896, the total loans were but a little over $\$ 1,000,000$ on 192,000 articles; in Hamburg for 1896 , $\$ 380,000$ on 96,000 articles; in Munich, $\$ 940,000$ on 417,000 articles; in Dresden, $\$ 980,000$ on 136,000 articles; and in Leipzig, $\$ 600,000$ on 176,000 articles.

In Austria the system of pawnshops is much the same as in the German Empire. At Vienna and Prague there are royal institutions, while the other large cities have municipal establishments. Private pawnshops are also allowed where the public authorities have not undertaken this function, or where the public institutions do not meet the needs of the population. 1 In Hungary there are municipal pawn offices at Budapest and all the larger towns. ${ }^{2} \mathrm{~A}$ few are also to be found in Russia, as at Riga, Moscow, Odessa, and Nikolaiev.

Monts de piêté are found in 44 French cities, including all but one of the 16 cities. with over 90,000 population. Each institution is managed by a director, with an unsalaried advisory board. The members of the board are appointed by the prefect of the department, but the maire is ex officio chairman; one-third of the members must be selected from the municipal council, and one-third from the charity.board. The director is appointed by the prefect on the nomination of the board. In Paris the minister of the interior makes the appointments, and the board consists of nine appointed members, with the prefect of the Seine and the prefect of

1 Contemporary Review, Vol. 66, p. 190.

2 British Foreign Office Reports, Parliamentary Papers, 1894, Vol. 90. 
police. The capital of the institutions consists largely of legacies and gifts; but there are also subventions from the communes, departments, and the state. At Grenoble and Montpellier the endowments enable loans to be made without interest; and in other places small loans are given gratuitously. Any surplus that may be accumulated goes to the support of hospitals or other charitable institutions.

The total amount of loans by all the establishments in French cities during 1897 was $\$ 13,000,000$ on $2,962,984$ articles. About one-third of the loans were for less than 5 francs, and another third between 5 and 10 francs. ${ }^{1}$ The transactions of the Paris institution amounted to over $\$ 6,600,000$ in loans on $1,138,000$ articles, showing a much larger average loan than in other cities.

Similar institutions are found in the principal cities of Switzerland, Italy, Spain, and Spanish-America. As in France, the government as well as the municipality have a voice in the management. Thus at Rome two members of the board of managers are chosen by the provincial council, and five by the municipal council.

While this sphere of municipal activity has been so generally entered by the large cities of continental Europe, none of the British or American municipalities have yet undertaken a similar work. In Great Britain the business of pawnbroking is licensed by the central government, and both there and in the United States pawnbrokers are subject to police control. Public institutions, by making loans at moderate rates of interest, are, however, a valuable assistance to the system of public charities; while they also coöperate with the police in recovering stolen property more readily than do private institutions.

\section{Savings Banks}

During the seventeenth and eighteenth centuries the public loan offices in Italy, Belgium, and other continental countries acted not only as pawnshops, but also as deposi-

1 Annuaire Statistique de la France, 1899, p. 35. 
tories for savings. This combination still survives in a number of countries, more especially in Italy, ${ }^{1}$ Spain, and Spanish America; and there is an instance, also, at Nancy, in France. In the other countries where public loan offices are common, savings banks are usually separate institutions; but they are generally under a similar system of municipal control.

A municipal savings bank was established at Karlsruhe in 1816, one at Berlin in 1818, and in the years immediately following similar municipal establishments were inaugurated at other cities in Germany and in a few French cities. Since then private savings banks have attained a large development; while in more recent years national institutions in connection with the postal service have been established in many countries. But the municipal establishments have also increased steadily, especially in Germany, Austria, France, and Italy; and in all of these countries they are much more important than either private or national savings banks.

None of the German states have established postal savings banks, and perhaps on that account the municipal establishments are most numerous in those countries. An exhaustive investigation made by the Prussian government showed that in 1896 there were in Prussia 792 municipal savings banks, 376 provincial banks, and 315 private institutions. In Bavaria there were 325 municipal establishments to 75 of other kinds, Baden had 123 municipal savings banks, and Hesse, 43. From the large number of municipal institutions it is evident that they are to be found in small cities and towns as well as in the larger communities. Among the latter, municipal establishments are almost universal. Of the 52 largest cities, 45 have municipal savings banks; and the only exceptions in cities of over 100,000 population are Hamburg and Bremen. The statistics in a few of the largest cities for the year 1897 are given herewith: ${ }^{2}-$

1 Provinces of Modena and Parma.

${ }^{2}$ Statistisches Jahrbuch Deutscher Städte, VIII, 105. 


\begin{tabular}{|c|c|c|c|c|c|c|c|c|}
\hline \multicolumn{7}{|c|}{ City } & \multirow{2}{*}{$\frac{\text { Number of Books }}{608,888}$} & \multirow{2}{*}{$\frac{\text { Amount of Deposits }}{\$ 52,566,000}$} \\
\hline Berlin & • & • & . & . & • & . & & \\
\hline Munich & • & • & - & - & - & . & 71,903 & $8,109,000$ \\
\hline Leipzig & . & • & • & • & • & - & 170,145 & $14,333,000$ \\
\hline Dresden & . & . & . & - & • & - & 239,916 & $18,521,000$ \\
\hline Cologne & . & . & . & • & . & . & 91,646 & $11,068,000$ \\
\hline
\end{tabular}

In Austria there are national postal savings banks, but municipal institutions do by far the largest share of the business. There are 368 of these, by the latest report, as well as 26 provincial and 66 private establishments. At Vienna, in 1895, there were 460,000 depositors with $\$ 73,000,000$ in deposits, and at Prague 141,000 depositors and $\$ 42,000,000$ in deposits. ${ }^{1}$

There are 458 municipal savings banks in France and but 86 private institutions. The national postal system has nearly 7500 offices; but the municipal and private institutions do four-fifths of the business. In 1897 they had 6,772,582 accounts and $\$ 685,400,000$ of accumulated deposits, while the national system had $2,944,685$ accounts and $\$ 168,800,000$ of accumulated deposits. ${ }^{2}$ The managing boards for the French municipal institutions are composed of the maire and fifteen directors elected by the municipal council for three-year terms, five of whom must be members of the council. At Paris the board of directors has twenty-five members, five retiring each year; and their successors are chosen by the remaining members, subject to the approval of the minister of commerce. All of the local banks in France are subject to the supervision of the finance department of the national government. ${ }^{3}$

In most provinces of Italy the savings banks are under the management of private semi-philanthropic societies. Thus, at Milan, the autonomous charity board conducts a savings bank, with branches in neighboring localities. ${ }^{4}$

1 Oesterreichisches Statistisches Bureau, 1895.

2 Annuaire Statistique de la France, 1899, pp. 71, 76.

s Block, Dictionnaire de l'Administration, p. 396.

4 Ibia., p. 405. 
Municipal institutions are found, to some extent, in Switzerland, Denmark, and Sweden; and in Russia there is one establishment at Riga, in operation before the national postal system was introduced.

Private institutions and national postal systems occupy the savings bank field in other countries. Even in Belgium and Holland, where municipal pawn offices are so general, there are no municipal savings banks. In the United States there is no national postal system; and the entire business is conducted by private establishments, subject to a limited supervision by the state governments. 


\section{CHAPTER $\mathbf{X}$}

\section{EDUCATION}

Authorities.- N. M. Buther, editor : Education in the United States. U. S. Bureau of Education: Reports, 1889-1890, 1890-1891 (foreign systems), 1893-1894, 1898-1899. Graham Balfour: The Educational Systems of Great Britain and Ireland. - R. G. Boone : Education in the United States. - Seeley : German School System. - Bolton : Secondary Schools in Germany. - Russell : German Higher Schools. - J. L. Pickard: School Supervision.-Douglas Campbell: The Dutch in England, Holland, and America. - N. S. Shaler: The United States of America. - Chicago Educational Commission's Report, 1899. - Educational Review, $17: 464 ; 20: 61,99,141$ - Annals of the American Academy of Social and Political Science, 15: 27, 271. - Dial, XXVI, 107-109.

\section{ELEMENTARY SCHOOLS}

EdUcational history begins with the earliest civilizations; but modern city school systems, like other municipal activities, are of comparatively recent development. During the Middle Ages, and in most countries until well into the nineteenth century, the educational system 'was almost entirely under ecclesiastical or private control; and schools were supported by fees or charitable endowments. There were, however, some exceptional instances of municipal action. In Germany, from the later Middle Ages, some of the cities had furnished financial aid to the schools. In the New England colonies, from the middle of the seventeenth century, there were public schools supported by the towns. ${ }^{1}$ In Scotland an act of 1696 required every parish to establish a school.

1 The Massachusetts school law of 1647 provided that: "To the end that learning may not be buried in the graves of our forefathers . . . it is ordered that every township within this jurisdiction shall appoint one within their towns to teach all such children as shall resort to him to write and read, 
The development of an organized school system began in Prussia. In 1713 a general school law was issued by Frederick William I, and during his reign 1800 public schools are said to have been established. Frederick the Great, in 1763 , issued a general school regulation which established the foundation of the Prussian school system. This provided for compulsory education, regulated the selection of teachers, and established a system of school supervision. And in 1794 another important statute declared the public schools to be state institutions, and made their support an obligatory charge on the heads of families in each district. ${ }^{1}$

In America the town schools of New England were duplicated in the other Northern colonies. During the eighteenth century, however, the system of petty school districts within the town, each with an independent local committee, arose; and with this method of administration the small rural school was introduced to the newly settled districts. Beginning with New York, in 1812, a development of state supervision became noticeable, and by 1850 school systems were organized in most of the Northern states. In 1837 a city school superintendent was appointed in Buffalo. This was followed by the appointment of a similar official in other cities, and by 1855 superintendents had been placed at the head of the municipal school systems in most of the principal cities. ${ }^{2}$

With the exception of Germany, very little was done along educational lines by the governments of Europe before 1850 . Two important steps were taken in 1833, when, in France, a law was enacted requiring each commune to maintain a

whose wages shall be paid either by the parents or masters of such children, or by the inhabitants in general ... further ordered that any town . . . of one hundred ... householders . . . shall set up a grammar school, the master thereof being able to instruct youth so far as they may be fitted for the university."

1 Von Reitzenstein, Kommunales Finanzwesen, p. 663.

2 Providence, 1839 ; New Orleans, 1841; Cleveland, 1844; Baltimore, 1849 ; Cincinnati, 1850; Boston, 1851; Newark and Brooklyn, 1853; Chicago and St. Louis, 1854 ; Philadelphia, not until 1883. BUtLer, Education in the United States, p. 124. 
public school, and in England the British Parliament established the system of government grants to the private and ecclesiastical schools in that country. During the last half century the public schools have developed rapidly in all the principal countries of Europe and America. It was not, however, until 1870 that a system of public schools was established in England, to be managed by an elected school board in each town. The later development has included radical changes in the subjects taught, the methods of teaching, the training of teachers, and the organization and the supervision of schools. In all the more important countries, too, the elementary schools are now supported entirely from public funds, and with no tuition fees; and in many countries attendance at school is required of all children of school age.

These various systems of school administration include, usually, both central and local authorities, while the latter occupy widely varying relations to the other municipal authorities. It is iherefore important to note the relative extent of central and local control and of central and local taxation for school purposes, and also the position of the local authorities in the general scheme of municipal government.

The most centralized systems are to be found in France, Russia, and Prussia. In France each commune must establish a free elementary school, and provide a site, buildings, and supplies; while there is a municipal committee charged with the duty of encouraging attendance at the schools. ${ }^{1}$ The responsibility of the commune here ends. The teachers are appointed by the prefects of the departments; the details of management are arranged by the department school boards; the state minister of education regulates the system of instruction in minute detail; and the central government pays directly the teachers' salaries. Again, in Russia, the city school commissioners have charge only of the material needs of the schools; while the final appointment of teachers, the program of study, and the choice of books are controlled by the minister of public instruction. And in

1 In Paris there is one such committee in each arrondissement. 
Prussia the system of instruction is minutely regulated by the state; the appointment of the teachers must be confirmed by the administrative authorities of the district (bezirk); and since 1889 the government subventions have paid the larger part of the salaries and other expenses of the personnel.

In the other countries of continental Europe, in Great Britain, and in the United States there is, in every city, a local authority which has direct control of the schools, selects the instructors, and has a large range of freedom in the organization of local schools and systems of instruction. State action in these countries consists in establishing certain minimum requirements of school service and educational standards, with a system of supervision and inspection, accompanied by grants in aid of the schools. Of the countries in this group, the central supervision is, perhaps, the most thorough in England and Scotland; and there the government grant pays an important share of the school expenses. In Italy and Belgium these grants are made only to the poorer towns; and in the United States the net result of a state school tax (which is not found in every state) is to aid the rural schools at the expense of the cities. In this country, too, the local authorities are subject to a very slight supervision, except in New York, where there is a considerable state control, mainly over the rural school districts and the secondary schools.

The local school authorities in the continental countries of Europe are always a distinctly municipal body. But in Great Britain the school boards are entirely independent of the town council. They are elected by popular, cumulative vote on general tickets, ${ }^{1}$ and have not only the direction of the schools, but also full power to determine the expenditures and to levy local school taxes. Where there is no school board, the town council has a school attendance committee to enforce the compulsory attendance law; but the management of the "voluntary" schools is independent of the council.

1 Except in London, where the members of the school board are elected in eleven districts, each returning five members. 
Only five towns of over 50,000 population have no school board; but nearly half of the smaller boroughs (114 out of 291) have none, and in other urban districts "voluntary" schools predominate.

In the cities of the United States there is no exact uniformity in the organization of school authorities nor in their relation to the municipal government. The general statement may be made that in most cases the relation is intermediate between the British system of independent boards and the continental system of distinctly municipal authorities. What may be called the typical organization has been described in these words:-

"A board of education is created by law, whose members are selected by the people, serve without pay, and have full legal power to establish and control free public schools for all children of school age in the limits of the city. Each year they make estimates in detail of the amounts of money required for the schools during the next coming year, which estimates are submitted to the city council. That body appropriates money for those purposes named in the estimates which they think necessary and proper, in view of all the other needs of the city government, and of the expected revenue from the taxes which they think it expedient to levy. The money, once appropriated, is controlled by the board of education, who buy sites, build and repair schoolhouses, purchase supplies, and pay for the necessary officers and teachers. They make regulations for the management of the system, and employ, as their executive officers, a secretary and a superintendent, the former to look after the details of their business affairs, and the latter to have special care of all matters relating to instruction."1 The important difference between this and the British system is that in the United States the appropriations must be secured from the municipal council.

There are, however, many variations from this type, and some of the most important must be noted. In several cities

1 James C. Boykin, Report of Commissioner of Education, 1895-1896, I, 33. 
the boards of education are appointed by the mayor: in Chicago, Baltimore, San Francisco, Jersey City, and St. Paul. In New York the mayor appoints the members of the four borough boards, and a central board of 19 members, for the whole city, is composed of delegates from the borough boards. In Savannah the mayor appoints 3 members, and the other 6 are a close corporation. In New Orleans a part of the board is appointed by the city council, and a part by the governor. In Milwaukee the board is selected by a committee of 4, appointed for this purpose by the mayor. In Philadelphia the central board of 40 members is appointed by the judges of the Superior Court, but there are also locally elected boards in each ward. In Pittsburg there are 36 elected district boards, and a central board of 39 members, chosen by the district boards.

These city boards of education have generally been composed of from 15 to 40 members, ${ }^{1}$ but in several recent reorganizations a small board has been substituted for the larger one. In Toledo and Indianapolis the boards of education have only 5 members, elected by the people; and in Cleveland, Minneapolis, and St. Paul only 7 members, those in the two former cities being also elected by popular vote. The new charter in San Francisco provides for a paid bipartisan board of 4 members, to be appointed by the mayor. In San Francisco, Cleveland, and Buffalo, the paid city superintendent of schools is elected by the people; and in the latter city this official acts in conjunction with a committee of the council, without a board of education.

In contrast with these measures, which tend to make the school management simply one department in the general municipal organization, there are other cases where the school board has been given the power of taxation, and is thus established as a completely independent authority. Important instances of this are to be found in St. Louis (where the school tax rate is limited to four mills), Boston, ${ }^{2}$ Cincinnati, Indianapolis (where the limit is five mills),

1 Boston, 24 ; St. Louis, 12 ; Cincinnati, 31 ; Detroit, 17 ; Providence, 33.

2 Independent authority began in Boston in 1898. 
Minneapolis, Omaha, and Lincoln. In New York a recent statute makes compulsory a levy of four mills on the dollar for school purposes, and gives the board of education complete control over the proceeds.

Many laws recently enacted give the superintendent of schools greater power in regard to the appointment of teachers, course of study, and selection of text-books. In Indianapolis the choice of teachers, from an eligible list, rests absolutely with the superintendent; but in Baltimore, St. Louis, Rochester, and Toledo the superintendent's choice must be confirmed by the board.

The statistics on the following page illustrate the recent development and some prominent features of elementary education in the United States, England and Wales, France and Prussia. In all of these countries there has been a marked increase in number of schools and scholars, in addition to the growth resulting from increase in population; except that in Prussia school attendance since 1840 simply keeps pace with the growth of population. The most striking recent development has been in England and Wales, since the establishment of the Board schools. At the present time, the United States and Prussia lead in the proportion of children attending school. The United States has a larger enrolment in proportion to population than the registration in the Prussian schools; but the average attendance in the former is little more than two-thirds of the enrolment. The average attendance in England and Wales is about the same in proportion to population as in the United States; but the total number of children at school will be proportionately less. The statistics for France show a much smaller number of scholars in proportion to population than in either of the other countries. The much larger number of schools in the United States is due to the more widely scattered population in the rural districts, and the consequent necessity for a great many small schools. One striking difference between the American and Prussian schools is in the relative proportions of men and women teachers. 
EDUCATION

\section{STATISTICS OF ELEMENTARY SCHOOLS}

\section{United States}

\begin{tabular}{|c|c|c|c|c|c|c|c|}
\hline \multirow{2}{*}{ Year } & & \multirow{2}{*}{$\begin{array}{l}\text { Number } \\
\text { of } \\
\text { Schools }\end{array}$} & \multicolumn{2}{|c|}{ Teachers } & \multirow{2}{*}{$\begin{array}{l}\text { Percentage } \\
\text { of School } \\
\text { Population } \\
\text { Enrolled }\end{array}$} & \multirow{2}{*}{ Enrolment } & \multirow{2}{*}{$\begin{array}{c}\text { A verage } \\
\text { Daily } \\
\text { Attendance }\end{array}$} \\
\hline & & & Men & Women & & & \\
\hline 1870 & • & 132,119 & 90,293 & 129,932 & 61.45 & $7,561,582$ & $4,545,313$ \\
\hline 1880 & & 178,222 & 122,795 & 163,798 & 65.50 & $9,867,505$ & $6,144,133$ \\
\hline 1890 & . & 224,526 & 125,525 & 238,397 & 68.61 & $12,722,581$ & $8,153,635$ \\
\hline 1899 & • & 244,527 & 131,793 & 283,867 & 69.34 & $15,138,715$ & $10,286,092$ \\
\hline
\end{tabular}

England and Wales

\begin{tabular}{|c|c|c|c|c|c|c|c|c|c|}
\hline \multirow{2}{*}{\multicolumn{4}{|c|}{ Year }} & & \multirow{2}{*}{$\begin{array}{c}\text { Number } \\
\text { of } \\
\text { Schools }\end{array}$} & \multicolumn{2}{|c|}{ Teachers } & \multicolumn{2}{|c|}{ Average Attendance } \\
\hline & & & & & & $\begin{array}{l}\text { Voluntary } \\
\text { Schools }\end{array}$ & $\begin{array}{c}\text { Bosrd } \\
\text { Schools }\end{array}$ & $\begin{array}{l}\text { Voluntary } \\
\text { Schools }\end{array}$ & $\begin{array}{c}\text { Board } \\
\text { Schools }\end{array}$ \\
\hline 1860 & . & - & • & • & 6,012 & 6,433 & & 751,325 & \\
\hline 1870 & . & - & • & - & 8,919 & 12,744 & & $1,168,981$ & \\
\hline 1880 & . & & • & . & 17,614 & 22,502 & 8,920 & $1,981,664$ & 769,252 \\
\hline 1890 & . & . & • & - & 19,419 & 27,012 & 19,527 & $2,260,559$ & $1,457,358$ \\
\hline 1899 & . & . & • & . & 20,064 & $28,443^{1}$ & $30,371^{1}$ & $2,499,133$ & $2,023,850$ \\
\hline
\end{tabular}

France, $1897-1898$

\begin{tabular}{c|r|r|r|r|r}
\hline & $\begin{array}{c}\text { Number } \\
\text { of } \\
\text { Schools }\end{array}$ & \multicolumn{2}{|c|}{ Teachers } & \multicolumn{2}{|c}{ Scholars } \\
\cline { 5 - 6 } \cline { 5 - 6 } & & & Women & \multicolumn{1}{|c|}{ Boys } & \multicolumn{1}{|c}{ Girls } \\
\hline Schools for Infants & & & & \\
aged 2-6 . . . & 5,739 & $9,544^{2}$ & & 376,616 & 372,510 \\
Elementary Schools & 83,915 & 69,700 & 85,705 & $2,777,739$ & $2,757,386$ \\
Mixed Schools . . & 20,929 & & & 388,333 & 339,298 \\
\hline
\end{tabular}

Prossia (Volkschulen)

\begin{tabular}{|c|c|c|c|c|c|c|c|c|c|}
\hline & \multirow{2}{*}{\multicolumn{3}{|c|}{ Year }} & & \multirow{2}{*}{$\begin{array}{c}\text { Number } \\
\text { of } \\
\text { Schools }\end{array}$} & \multicolumn{2}{|c|}{ Teachers } & \multicolumn{2}{|c|}{ Scholars } \\
\hline & & & & & & Men & Women & Boys & Girls \\
\hline 1822 & . & . & - & - & 20,440 & 21,766 & 454 & 743,207 & 683,838 \\
\hline 1840 & . & . & . & . & 23,323 & 26,948 & 1,559 & $1,133,288$ & $1,090,951$ \\
\hline 1861 & . & . & . & . & 25,156 & 32,173 & 2,652 & $1,406,014$ & $1,372,794$ \\
\hline 1871 & . & . & . & . & 33,130 & 43,211 & 3,848 & & $3,900,655^{2}$ \\
\hline 1891 & - & • & . & . & 34,742 & 67,204 & 8,903 & $2,467,558$ & $2,448,918$ \\
\hline 1896 & - & . & . & - & 36,138 & 71,716 & 10,354 & $2,624,716$ & $2,612,110$ \\
\hline
\end{tabular}




\section{SECONDARY SCHOOLS}

Higher grade schools are, to a much larger extent than the elementary schools, independent of the municipalities. Only in the United States are all of the public secondary schools under the same control as the elementary schools. In continental Europe government support of secondary schools preponderates over municipal; but nevertheless there are a considerable number of municipal schools, especially in France (e.g. the collèges), and tuition fees are required in most cases.

Secondary schools may be divided into two general groups: (1) those for general culture and preparatory to university education; (2) technical schools for trades and business life. While, to some extent, there are schools which give instruction in both directions, yet the two classes are, in the main, so distinct as to render a separate discussion advisable.

High Schools and Academies. - In the United States the secondary schools for general culture consist of public high schools, under the control of municipal school boards, and academies, under private management. Before 1850 the latter constituted almost the only secondary schools in the country; and as late as 1880 there were but 26,609 students in public high schools as compared with 75,840 in academies. During the last twenty years, however, there has been an astonishing development in the public high schools; and by 1899 there were 5495 of these schools with an aggregate of 476,227 students, as against 1957 academies with 103,838 students. The high schools are very largely city institutions. Cities of over 8000 population contained 731 schools, with 224,686 students and 7563 teachers, nearly half of the total number of high school students in the United States. With few exceptions the public high schools are coeducational; and over the whole country the girls exceed the boys in number. In the total attendance the ratio is about four girls to three boys; but many boys leave before finishing the course, and the number of girl graduates in 1899 was 36,124 , as compared with 20,344 boys. 
In the different cities the relative number of students in the high schools varies a good deal. The Southern cities nearly all show a small proportion as compared with the Northern cities. Among the latter, a few cities are especially noteworthy for the large proportion of high school students: Washington (3427), Providence (2943), Kansas City, Mo. (3116), and Worcester (3124). Some of the Northern industrial cities, as Allegheny, Scranton, Camden, Bridgeport, and Troy, still rank low in the scale. ${ }^{1}$

The German schools which correspond most nearly to American high schools and academies are the Gymnasia and Realschulen. These institutions, which are distinctly boys' schools, do much more advanced work than American high schools; and while they receive large government and municipal appropriations, they also have a large income from tuition fees. Prussia in 1897-1898 had 220 institutions classed as state establishments, 305 municipal schools, and a few others, with a total of 148,327 students $^{2}$ above the pre-

1 High School Statistics, 1899

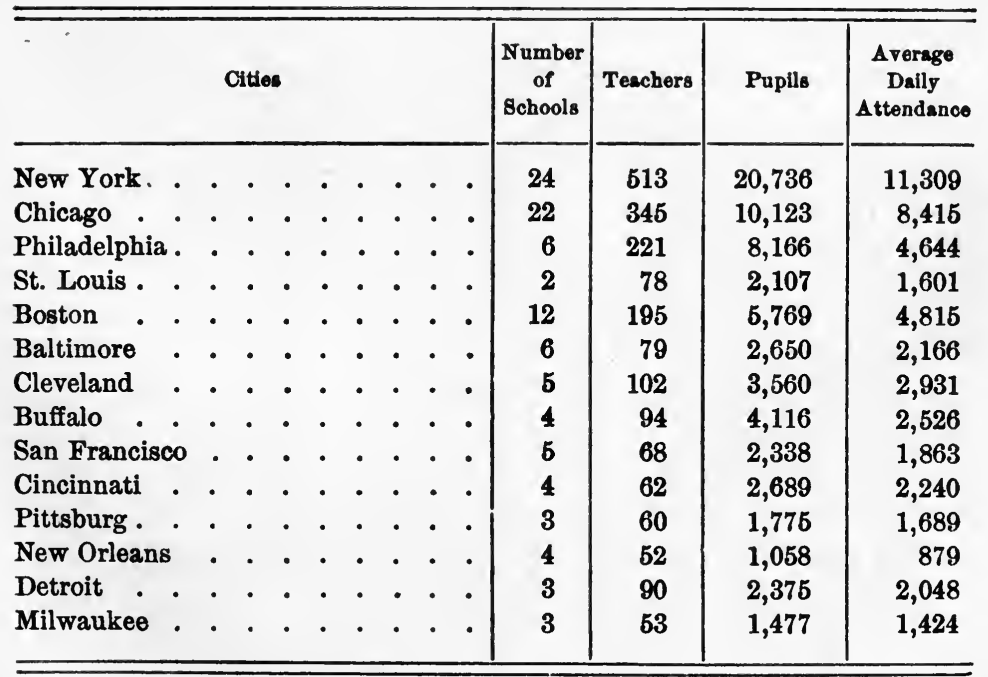

2 Statistisches Handbuch der Preussischen Monarchie, III, 479, 488. 
paratory classes. In the poorer provinces of eastern Prussia, municipal schools of this grade are found only in the large cities, such as Breslau, Königsberg, and Danzig; but in the wealthy western provinces the proportion of municipal institutions rises as high as 50 per cent. 1 In Bavaria the classical schools are government institutions, while the other secondary schools are under local management. Most of the secondary schools in Württemberg are municipal, but receive government support. Saxony has 15 distinctly government schools, 35 classed as municipal, and 7 endowed institutions; but many of the municipal institutions receive state aid, and are subject to state control, while the total amount of municipal appropriations for secondary education in Saxony is but two-thirds of that given by the government.

The following table gives statistics of secondary institutions in some of the principal German cities for the year $1897-1898:^{2}-$

\section{BOYS' SCHOOLS}

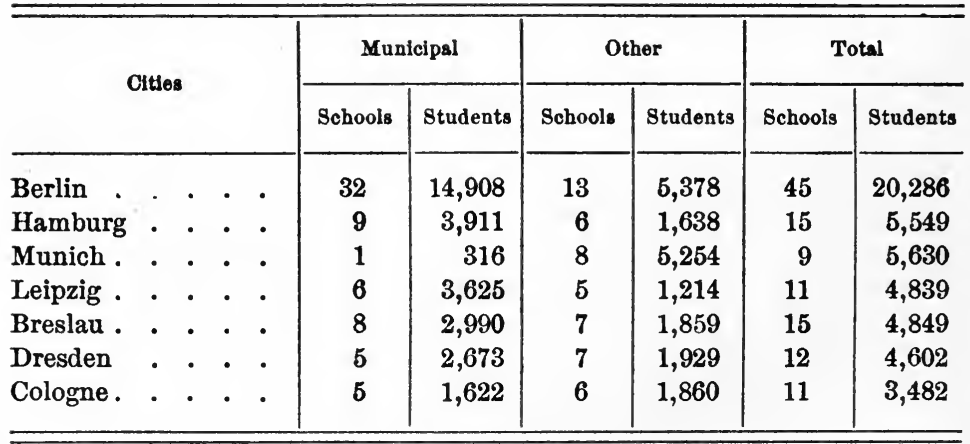

These are all schools for boys only. Very little is done in the way of secondary education for girls; and, as the table below shows, most of the institutions for this purpose are not municipal in character.

1 Report of Commission on Secondary Education, V, 611.

2 Statistisches Jahrbuch Deutscher Städte, VIII, 159 ff. 


\section{GIRLS' SCHOOLS}

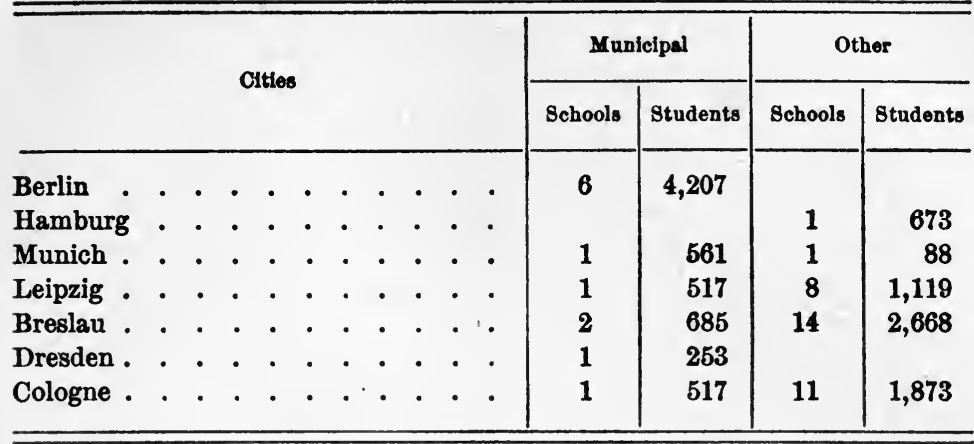

French secondary schools include two classes of institutions: the lycees, under the immediate and exclusive control of the state, and the collèges, which receive some support from municipal funds, but have their directors and principal officials appointed by the minister of the interior, and are under the close supervision of the general educational officials. There are also many private and church schools, which have been gaining in recent years at the expense of the public schools, and have now the larger number of students. Statistics for $1898^{1}$ are as follows:-

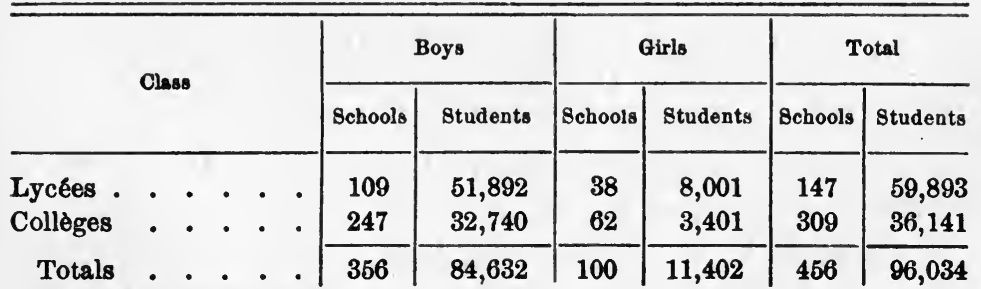

Private and Church, 1897 . . 97,382

Total . . . . . . . $\overline{182,014}$

Italian secondary schools are classified much like those in France, but, as shown in the following table, the attendance is much smaller :- 


\begin{tabular}{|c|c|c|c|c|c|c|c|c|c|}
\hline & & & & \multicolumn{2}{|c|}{ Gymnasia } & \multicolumn{2}{|c|}{ Lycées } & \multicolumn{2}{|c|}{ Total } \\
\hline & & & & Schools & Students & Schools & Students & Schools & Students \\
\hline State . . & - & - & . . & 183 & & 116 & 10,945 & 299 & \\
\hline Communal & . & . & . . & 89 & & 22 & 1,277 & 111 & \\
\hline Other . . & - & - & - & 436 & & 194 & 5,464 & 630 & \\
\hline Total & . & . & . & 708 & 55,515 & 332 & 17,689 & 1040 & 73,204 \\
\hline
\end{tabular}

In the other countries of continental Europe the secondary institutions are mainly under government control, although some local schools receive municipal aid. Belgium has 30 communal institutions to 130 national; while the government expenditure for secondary education is double the municipal grants. There are 17 state and 33 municipal secondary schools in Norway; but most of the latter receive government subventions, and are under the supervision of the central department of education.

There is no organized system of secondary education in Great Britain. The endowed grammar schools and private schools, for which no complete records are available, are almost the only provisions offered; and only in a few cases have either school boards or the town councils aided in the work. In all England there are about 80 higher grade schools maintained by the local school boards, aided in some cases by grants from the borough councils. Most of these are in the county boroughs; 35 are in the three northern counties of Lancaster, York, and Durham, and 19 others are in the eight midland counties. Probably the best of these is the Central Higher Grade school in Leeds, with about 700 secondary students, which equips its pupils for the university examinations. In Scotland, secondary education in the public schools is much more advanced than in England; and most school boards in urban communities provide for secondary as well as elementary instruction.

Technical Schools. - Industrial education, as distinct from general culture, has developed mainly within the last three 
decades. Its beginnings are usually dated from the establishment, in 1776, of manual training at a Moravian school for boys in Saxony, whence it spread slowly in Germany. The municipal movement in this direction began at Ghent in 1817. By 1844 there were five municipal manual training schools in Belgium; and three years later a royal decree recognized these schools and provided for government supervision. After 1860 many new schools were established in the Belgian cities. During the seventies the general movement spread to Holland, and a few schools were established in France at some of the larger cities, as Paris, Havre (in 1866), Lyons (in 1857), Rheims, and Lille (in 1872). In the eighties the number of manual training and secondary technical schools in France and Germany rapidly increased, and similar schools began to be established in England and the United States. The last decade of the nineteenth century witnessed a continued growth in all the principal countries. In this development all sorts and complications of state, municipal, and private action are to be found.

Secondary technical education is most highly developed in Germany, and here, too, municipal schools and municipal assistance are most prominent. A consular report of 1899 states that there are 860 schools in 605 places in Germany where manual training is taught. Prussia has 570 such schools in 435 places, mainly in the industrial districts of upper Silesia and the Rhine province. ${ }^{1}$ There are over 100 schools of this kind in the kingdom of Saxony, and nearly 50 in Bavaria.

Berlin has, of course, the largest equipment of schools for industrial training. In 1895 there were 28 continuation schools, with 12,000 students, ${ }^{2}$ teaching modern languages, mathematics, bookkeeping, shorthand, drawing, and modelling; and also about 15 trade schools for carpenters, housepainters, saddlers, smiths, wheelmakers, shoemakers, glaziers, masons, and others, with 9000 students, and municipal grants of $\$ 129,000 .^{3}$ Small fees are charged, and some finan-

1 Consular Reports, November, 1899.

2 Statistisches Jahrbuch Deutscher Städte, V, 196.

${ }^{8}$ Report of United States Commissioner of Education, 1895-1896, II, 1220. 
cial aid is received from various trade associations; but the main support of the schools are the municipal grants. Hamburg has 9 trade schools with 4140 pupils; Dresden, including both trade and manual training schools, has 28 institutions with over 4000 pupils. All the other important German cities have made provisions in this field, either by the establishment of schools for manual training only, or by special industrial instruction in the advanced schools.

In Belgium there were about 150 manual training and industrial schools for boys, with 20,033 pupils in 1895-1896, and 225 housewifery schools for girls, with 9539 pupils. The municipal grants to these amounted to $\$ 100,071$, which was somewhat less than the government grants, and more than a fourth of their total income. Small municipal appropriations are also made to the Higher Commercial Institute at Antwerp, and to the School of Mines and Industry at Mons. These institutions are governed by local boards, representing the various public authorities. Generally the governor of the province and the burgomaster of the city are ex-officio members, and there are two members chosen by the municipal council, two by the executive committee of the province, and two by the central government.

In 1893 there were 18 trade schools in Holland, two at Rotterdam, and one each at Amsterdam, The Hague, Utrecht, Groningen, Harlem, and smaller towns. At Amsterdam, Rotterdam, The Hague, and Arnheim there are industrial schools for girls. All were established at first by private initiative, but are now supported wholly or partly by municipal and government subsidies. The board of directors in Rotterdam is chosen by the city council from a double list of nominations, submitted by the private association which established the school. The instruction in these schools is, for the most part, of a general nature, including arithmetic, algebra, geometry, physics, mechanics, industrial economy, and drawing; but there are also special courses in electricity, chemistry, and other applied sciences.

The French schools of this character are under the supervision of the minister of commerce and industry. In addi- 
tion to many national technical schools, there were, in 1899, 25 schools of commerce and industry, with 3900 pupils, which received $\$ 115,000$ in municipal subsidies, and about the same amount from the general government. ${ }^{1}$ There are, also, many other schools receiving only municipal aid, for which exact records are not at hand.

In Italy there were 387 technical schools in 1896, with 33,741 students. Of these 181 , with 21,591 students, were state institutions, and 115, with 8854 students, were municipal. ${ }^{2}$

Manual training schools have been established in about half of the cantons in Switzerland, including Zürich, Geneva, Berne, and Basel. All of the expenses of the Geneva school are paid from the public funds, while other schools receive grants from the federal and cantonal authorities. There are, also, municipal watch-making schools at Geneva, Neufchâtel, and several smaller places, and a municipal school of art at Geneva.

Even in the Northern countries of Europe there has been some municipal activity along this line. In Sweden there were, in 1892, 29 technical schools receiving municipal aid. Manual training is obligatory in the schools of Norway and Finland, and in the latter country there are trade schools in 12 towns receiving state and municipal aid. ${ }^{3}$

Most of the technical schools in Great Britain have appeared since the passage of the Technical Instruction Act of 1889 . Public aid is given, not by the school boards, but by the town councils. In 1895 all of the county boroughs and county councils spent part of certain government subventions for technical education. In addition, 16 county boroughs, 72 boroughs, and 123 urban districts made small grants out of local rates for this purpose. The total expenditure by local authorities on technical education in 1894-1895 was $\$ 3,650,000$. Most of this was in the shape of subsidies to private institutions, but several of the large cities have dis-

1 Annuaire Statistique de la France, 1899, pp. 612, 613.

2 Report of United States Commissioner of Education, 1898-1899, p. 859.

8 Consular Reports, XLIII, 209. 
tinct municipal schools. The Manchester corporation maintains a spinning and weaving school, a school of art and design, several schools for the mechanical arts, engineering, and trades; and also evening classes in commercial and industrial and engineering subjects, as well as girls' classes in dressmaking, millinery, and domestic pursuits. All together, property valued at $\$ 1,000,000$ is used for these purposes. Birmingham has erected a building for technical education at a cost of $\$ 450,000$. In this institution, accommodating 2600 pupils, special attention is given to the engineering, chemical, and electrical industries. Important municipal schools have also been established at Bradford, Salford, Oldham, Nottingham; Kingston-upon-Hull, Portsmouth, and West Ham. Municipal subsidies to private schools are given by Liverpool, Glasgow, Sheffield, and Leeds. ${ }^{1}$

The first manual training school in the United States was established at St. Louis, as a sub-department of Washington University, in 1878. The first municipal school was opened, in 1884, at Baltimore. By the last report there were 125 manual training schools, with 1077 teachers and 38,621 students, in the United States. In addition to these, most of which are private institutions, manual training was also given in the public schools of 170 cities - a Massachusetts law requiring such instruction in all the cities of that state having a population of 25,000 and over. Education in commercial and business methods is also given in many municipal high schools; but distinct "business schools" are usually private institutions. Three hundred and twenty such schools were reported in 1899, with an enrolment of 70,186 students.

There are very few instances of municipal trade schools in America. The textile schools recently established at Lowell and New Bedford are almost unique. To the Lowell school the city gave $\$ 25,000$, the state (Massachusetts) an equal amount, and private subscriptions raised the total endowment to $\$ 100,000$. The school consists of a textile mill, which is operated by the students, under the instruc-

1 Donald, Municipal Year Book for 1900. 
tion of experts in the various processes; and its object is to train men to become designers and foremen in the textile industries. Technical instruction in the engineering sciences is furnished in private and state institutions (often as part of a university), but there is no important example of municipal aid.

Colleges and Universities. - Educational institutions of college or university rank are seldom exclusively municipal, and there are but few cases where such institutions receive any municipal aid. The Belgian universities at Ghent, Liège, and Louvain are partly supported by the municipal authorities. In England the municipal authorities of Kingston-uponHull and Southampton are represented on the governing boards of local colleges; Nottingham maintains a college which is managed by a board of three coöpted members and representatives from Oxford and Cambridge universities; and the great provincial cities, Liverpool, Manchester, Birmingham, and Leeds, grant aid to local colleges. The College of the City of New York, maintained by the corporation at an expenditure of $\$ 200,000$ a year, has been little more than a secondary school; but, with the development of the public high schools in that city, it is likely to become an important example of a municipal college.

\section{PUBLIC LIBRARIES}

Libraries or collections of books for the exclusive use of advanced scholars have been owned and maintained by some European cities since the end of the Middle Ages. But municipal libraries for general use, and intended as part of the educational facilities for the entire community, are another development of the latter half of the nineteenth century. The first action was taken by the city of Boston, in 1847, when, through the influence of Mayor Josiah Quincy, authority was secured from the Massachusetts legislature, and the new institution inaugurated. ${ }^{1}$ In 1855-1857 a public

1 Fletcher, Public Libraries in America. 
library building was erected at a cost, including land, of $\$ 365,000.1$ The example of Boston was soon followed by other cities in New England; and by the end of thirty years similar institutions had been established in most of the large cities in the Northern states. The movement in Great Britain began about the same time as that in America. In 1850 a parliamentary act was passed permitting boroughs to establish libraries, and in 1852 the first municipal public libraries were opened at Manchester and Liverpool. By 1870 the act had been adopted in forty places, of all sizes; and by 1883 there were 133 public libraries, only four of which were in London. The last two decades have been marked by an astonishing development of municipal public libraries in these two countries, both in the expansion of the libraries in the large cities, and in the extension of library facilities to small communities. In the same time there has been a considerable number of municipal libraries established in other countries.

In 1896 there were in the United States 627 libraries of over 3000 volumes each, entirely free to the public. Twothirds of the whole number of libraries were in the North Atlantic states, and one-fourth in the North Central states. In New England libraries are found in the smallest communities; in Massachusetts and Rhode Island almost every town has one. Some of these libraries are maintained entirely by private associations, while many have received large gifts and endowments, in addition to municipal aid. A frequent method of contributing private aid to libraries is the presentation of a building, with the provision that the municipality furnish the books and support; in a few cases, however, the gifts have included the original equipment of books.

Strictly municipal libraries are maintained by two-thirds of the cities with over 30,000 population (85 out of 129), and also by many smaller cities. Among cities of 100,000 population and over, only three are without municipal public libraries: Louisville, Providence, and Memphis. The largest of the purely municipal institutions is that of Bos-

1 Matthews, City Government of Boston, p. 71. 
ton. This contains $\mathbf{7 8 0 , 0 0 0}$ volumes, and in $\mathbf{1 8 9 9}$ circulated $1,250,000$ volumes. The new public library building, completed in 1895 at a cost of $\$ 2,650,000$, is one of the noted architectural structures in America. Besides this central building, there are 10 branch libraries, with reading rooms, in different parts of the city, and 20 additional stations for the delivery of books. The Chicago municipal library has 300,000 volumes, and an annual home circulation of $1,700,000$. The municipal libraries of Philadelphia, Baltimore, and Cincinnati have each about 200,000 volumes; and the circulation varies from 1,800,000 volumes in Philadelphia to 400,000 in Cincinnati. In all of these cities, and also in the large cities where there are no municipal libraries, there are large public libraries controlled by other authorities. In Washington the municipal district library is comparatively unimportant; but the government libraries, including the Congressional Library, with an aggregate of $2,500,000$ volumes, give that city the largest library equipment of any city except New York, although in point of value the various libraries in and around Boston excel those of Washington. In New York there are only 4 small libraries under municipal control; but there are over 60 private libraries, large and small, aggregating all together nearly 4,000,000 volumes, most of which receive municipal aid. Several of the principal libraries have been consolidated into the New York public library, for which the city is now constructing a building; but the management will remain under a board of coöpted trustees.

The management of municipal libraries is, in most cases, vested in a board of trustees, selected by the mayor or city council; but there are numerous exceptions. The Cleveland library board is selected by the school board, and in Cincinnati, Indianapolis, Erie, and other places, the school board has immediate supervision. Most of the states of the middle West follow Illinois in providing for elected library boards, which occupy a similar autonomous position to that of the city school boards.

In Great Britain and Ireland there are now about 350 municipal libraries, containing in all over $5,000,000$ books, 
with an annual circulation of $27,000,000$, and an annual attendance of $60,000,000$ readers. Only two cities of over 100,000 population (Glasgow and Burnley) have no municipal libraries; 6 of the 65 places with over 50,000 population have none; and of the 303 boroughs more than half have none. The 36 London libraries, each of which is under separate management, undoubtedly aggregate the largest number of volumes in municipal libraries in any British city. The most important library system under a single management is at Manchester. Here there is a central reference library, 12 lending libraries, and 5 additional reading rooms, with an aggregate of 280,000 volumes, and a circulation of $1,868,000$. Birmingham has a reference library of 143,000 volumes, a central lending library, and 9 district libraries, with a total circulation of $1,300,000$ volumes. Leeds has 21 branch libraries and 37 juvenile libraries, many of them located at the public schools and police stations. The total number of volumes is about 200,000 , and the annual circulation about $1,000,000$. Nottingham has a central library with 14 branches, and during 1899, 382,120 books were issued, and the total attendance at libraries and reading-rooms was 2,253,211. Glasgow has no municipal library; but there are two large reference libraries, one of which receives a grant from the corporation.

If we compare the public libraries in Great Britain with those of the United States, municipal activity is more prominent in the former country. There are fewer important cities with no municipal libraries, and private gifts and endowments are not so important. The American public libraries usually show a larger number of volumes, but the circulation is larger in Great Britain for cities of the same population.

More than 300 cities and towns in France have public libraries. But these are generally much less important than in British and American cities. Paris has a well-developed system of lending libraries; there are 100 offices in different parts of the city, under the direction of local arrondissement boards, with a central municipal bureau for the entire city. The municipal library of Lyons, which is over 200 years old, 
has 200,000 volumes, 2 main buildings, and 2 branches, with a total circulation of 120,000 volumes. The libraries at Rouen and Rheims have each about 120,000 volumes. But even where there is a considerable collection of books, there is comparatively little popular use. Nice, with 80,000 volumes, has a circulation of only 10,000 a year; and Brest, with 54,000 volumes, only 6000 a year.

So, too, in Germany, almost every large city has municipal libraries, but these are not used by the people, and only in a few cities are there people's libraries for the general circulation of books. At Berlin, in addition to the government and university libraries, there are 27 small people's libraries, with 100,000 books and an annual circulation of 375,000 . Dresden has a people's library, with 12 stations, 42,000 volumes, and an annual circulation of 150,000 . Cologne, Leipzig, Frankfort-on-the-Main, Düsseldorf, Mannheim, Cassel, Duisburg, and Wiesbaden give small municipal subsidies to private libraries. ${ }^{1}$ But even these instances are exceptional. It has been estimated that the total number of books loaned from the people's libraries in Germany is only about $4,000,000$ a year, as compared with $27,000,000$ in Great Britain and a still larger number in the United States.

The other countries of continental Europe show about the same condition as France and Germany. All of the important cities have municipal libraries, few of which have any large popular circulation. The library at Antwerp, with 77,000 volumes and a circulation of 91,000 volumes, is among the most active. Rotterdam has no municipal library, and Amsterdam has only an interest in the university library. Bologna (Italy) has a municipal library of 240,000 volumes, and an annual circulation of 33,000. There are no municipal libraries in Rome, Milan, or Florence.

\section{MUSEUMS OF ART AND SCIENCE}

In addition to the large government museums, the large cities of France, Belgium, and Switzerland almost invariably possess municipal art galleries and museums, with valuable

1 Statistisches Jahrbuch Deutscher Städte, VI, 116. 
collections of paintings. Antwerp has three municipal art galleries, especially rich in the works of the famous Flemish painters. In Brussels, Antwerp, and Liège there are academies of fine arts under the control and partial support of the municipal authorities. In Italy the national government has assumed control of most of the public art collections; but in Rome, Venice, Turin, and a few other large cities there are still important municipal galleries. In the other continental countries, too, the government owns all the leading art galleries; but there are also many municipal collections in the large cities of Germany, Austria, and Holland, and even in some cities of Northern Europe.

Most of the county boroughs in Great Britain have either an art gallery or a public museum, and many have both. Nottingham and Norwich each utilize a local mediæval castle for housing and exhibiting the municipal collection of works of art, together with articles of antiquarian and scientific interest. In connection with such institutions, Birmingham, Manchester, and other large boroughs have schools of art. The art collections of the British boroughs, however, fall far short in value of those in the leading continental cities.

In the United States distinctly municipal art museums are very exceptional. The most important are at Philadelphia and Providence. Small art collections and exhibitions in connection with the municipal libraries are found in Minneapolis, Milwaukee, Springfield, Mass., and a few other cities. More frequent are instances of municipal aid to museums under private control. New York has furnished land in the public parks, and also constructed expensive buildings, for the Metropolitan Museum of Art and the American Museum of Natural History. Boston gave the land on which the Fine Arts Museum has been erected. In general, however, municipal action in this field has been deficient, nor is the deficiency made good by government institutions.

\section{MUSIC AND DRAMA}

Many of the cities of continental Europe have municipal theatres and opera houses. These are most frequent in Ger- 
many, where, in addition to government opera houses in Berlin, Dresden, Hanover, Brunswick, Mannheim, and most of the ducal capitals, there are nearly forty municipal theatres, ${ }^{1}$ including those at Breslau, Cologne, and Frankfort-onthe-Main. In France, Belgium, Austria, and Russia many of the large cities own theatres or opera houses, as do also Rome, Milan, and other Italian cities, Geneva, Basel, Lisbon, Athens, and even small Greek cities, such as Patras and Corfu. The Paris theatres, as well as the Grand Opera House, receive large grants from the French government.

These municipal establishments are usually leased to a managing company or director, often for a nominal rent, while the city either guarantees a minimum profit or pays a fixed subvention. Subsidies to private establishments are also frequent in cities where there is no municipal theatre, and sometimes even where there is such, as at Florence, Barmen, Crefeld, Christiania, and Bergen.

As a result of the municipal aid, prices are so low that the performances are within the reach of every one. Thus at Marseilles the rates for the opera, fixed by the municipal council, are from 14 cents to $\$ 1.50$. At Nice the prices for ordinary performances are from 10 cents to $\$ 1.60$; and on Sundays these are reduced by one-half. On certain holidays free performances are given at the municipal theatres of Paris, Brussels, and other large cities.

The British and American cities have in no case established a municipal theatre or opera house; but many of them have taken a small step in this direction by establishing popular musical concerts. About one-half of the British county boroughs provide for public concerts in the parks during the summer months, while a smaller number arrange also for indoor popular concerts and organ recitals during the winter months. Glasgow has been the most active in the latter respect. Small fees (1d. to 3d.) are charged (though a number of free tickets are also distributed), which pay for the expenses and a small surplus as rent for the use of the municipal halls.

1 Zeitschrift der König. Preuss. Stat. Bureau, XXXVI, 270. 
Free public concerts in the parks are furnished in a number of American cities. New York city spends $\$ 40,000$ a year for this purpose; Philadelphia, $\$ 15,000$; and smaller sums appear in the budgets of Chicago, St. Louis, Boston, Buffalo, Denver, Omaha, Syracuse, Worcester, Allegheny, and some smaller cities. Boston in 1898 began a system of popular municipal indoor concerts during the winter; but this feature has not yet been adopted in America to any large extent. 


\section{CHAPTER XI}

\section{MUNICIPAL ImPROVEMENTS. I}

Authorities. - A. T. Brrne : Treatise on Highway Construction.-E. C. Lowe : Pavements and Roads (1891).-H. P. Boulvors: The Municipal and Sanitary Engineer's Handbook (1892). - Geo. W. Tillsov : Street Pavements and Paving Materials. - A. P. Rockwhll : Roads and Pavements in France (1896). - N. S. Shaler : American Highways. - Law and Clark : Roads and Streets (1877). - M. Merriman : Elements of Sanitary Engineering. - Hazex : Purification of Water Supplies. - MaxsField Merriam: The Elements of Sanitary Engineering. - Willin R. Billings: Some Details of Waterworks Construction. - Geo. E. WARINo, JR. : Sanitary Drainage of Houses and Towns. - H. N. OGDEN, C. E. : Sewer Design. - Geo. E. WAring, Jr. : Modern Methods of Sewage Disposal._Geo. W. RAFter and M. N. BAKER: Sewage Disposal in the United States. - E. C. S. Moore: Sanitary Engineering. W. F. GoophoE : Municipal Improvements, a Manual for the Municipal Officer. - American Law Review, 26 : 520.

\section{Streets, Bridges, and Tuknels}

Journal Franklin Institute, 36, 103 : 252. - Van Nostrand's Eclectic Engineering Magazine, 22 : 425; 24 : 237. - Popular Science Monthly, 7 : 80-89; 56 : 524-539. - Journal Royal Statistical Society, $9: 204 ; 27: 378$. - Journal Society of Arts, 42 : 61. - Engineering Neros, 23 : 292; $25: 281$. - Paving and Municipal Engineering, 18 :356. - Engineering Magazine, 8: 1014 ; $11: 844-866 ; 12: 59,245 ; 15: 905-921$. - Revue Municipale, $3: 209$. Engineering Record, 40 : 625 ; 41 : 105. -Consular Reports, 60 : 123. -Transactions American Society Civil Engineers, $29: 718 .-$ Review of Reviews, 20 : 60-64. - Century Magazine, 60:12. - Municipal Affairs, $3: 650-663$. - Scientific American, $82: 217$; 83 : 69, 114, 167, 226, 322.

\section{Sewers and Sewage Disposat}

Engineering News, Dec. 3, 17, 1881. - Engineering Record, Nov. 10, 1894. - Appleton's Cyclopedia, art. Sewage. - V. Hugo : Les Miserables, vol. 5, bk. 2. - Hunt's Merchant's Magazine, 12 : 53 ; 29 : 182. - Engineering Magazine, $1: 831 ; 2: 496 ; 8: 1007 ; 18: 774-775$. - Harper's Magazine, $71: 577$. -Century Magazine, 25 :939. - Nation, 58 :239; 59 :221. - Journal Royal Statistical Society, 7 : 143. - Journal Society of Arts, $25: 389$; 38 :66, 142 ; 47 : 683. - Journal Franklin Institute, 76 : 217, 289, 361 ; $77: 1$; 114 : 186-454. 
-Eclectic Engineering Magazine, $13: 32 ; 18: 272 ; 19: 124 ; 22: 382 ; 23: 49$. -American Architect, $11: 137,159,173 ; 13: 76 ; 16: 64,79,116,179,185$; $19: 272 ; 20: 126 ; 27: 156$.

\section{Scavenging}

Geo. E. WARING, JR.: Street Cleaning and Its Effects. - Popular Science Monthly, 38 : 748. - Engineering News, April 11, 1895. - Eclectic Engineering Magazine, 19 : 103. - Engineering Magazine, 13 :99.—McClure's Magazine, 9 : 911. - Review of Reviews, 15 : 437.

\section{Parks}

Atlantic Monthly, 79 : 86. — Engineering Magazine, 9:253.—Scribner's Magazine, 27 :637-640. — Nineteenth Century, $21: 677$; $23: 189$; $46: 26$. American Architect, $62: 11,27,35$. Contemporary Review, $50: 387$.-Chambers's Journal, 68 : 337. - Blackwood's Magazine, 46 :212; 51 : 380.—New Review, 7 : 701.

THE matters to be considered under this main head are the construction and maintenance of streets and bridges; sewer systems and other means for the removal of wastes; parks and other means of recreation for crowded populations; the supply of water, gas, and electric light; commercial and trade facilities (such as markets, docks, and harbors); and the means for rapid local transit. These various fields of municipal activity have several points in common. They present a side of public activity which is confined almost entirely to the large cities, and they include thus those functions of distinctly local interest. They have also the common characteristic that they are works of municipal engineering, and thus marked off from police, charities, and education. Lastly, in most cases they are functions connected with the construction and use of public highways and other property open for the use of the entire community.

These activities may be divided into two groups : 1 , those which are for the most part maintained from the proceeds of public taxation; and 2, those maintained by charges on consumption. The latter group include the so-called municipal monopolies; and the discussion on these subjects, in the next chapter, will include the questions of municipal ownership and the relations of municipal authorities to private companies, as well as the systems of direct municipal activity. The present chapter deals with the first group. 


\section{THE CITY HIGHW AYS}

\section{Street Pavements}

Modern city streets present radically different problems from those of country highways. The concentration of heavy traffic in urban communities necessitates a much firmer and more durable street surface, while the concentration of wealth in such communities makes possible expensive pavements which add to the convenience and comfort of city life. Nevertheless, the fundamental features of street construction do not differ from those for highway construction; and in noting the historical development of such public works, the earlier references must deal largely with country highways, which preceded in time, and led up to, special city streets.

Probably most of the ancient cities had some form of street pavements. Recent investigations in Mesopotamia have shown that in the old Assyrian city of Sargon the principal streets had paved causeways forty feet wide, composed of small, irregular, and not durable stones, which were, however, better than any pavement now to be found in that region. ${ }^{1}$ So, too, in Thebes, Jerusalem, and the Greek cities there were paved streets. The three-mile road from the port of Piræus to Athens had a stone pavement. But the first attempt at any extensive system of road construction seems to have been made by the Carthaginians; and it was probably from the roads of Carthage that the Romans learned the military advantages of good roads, and also the art of road construction. Appian Way, constructed 312 B.c., was the first of the famous Roman roads which, under the empire, reached out to all parts of the Roman dominion and mark the highest point in road construction until the eighteenth century. The streets of cities were also paved, although these works were not so noteworthy as the military highways. According to Livy, various streets in Rome were paved in the second century B.C. ; and in the ruined cities of Pompeii and Herculaneum street pavements of lava blocks have been

1 Perrot and Chipiez, History of Art in Chaldea and Assyria, pp. 53-77. 
discovered, which must have been constructed before the destruction of these cities in 79 A.D. Old paving stones in Rome, excavated by the French in 1813, were from twelve to fourteen inches deep, four to five square feet in surface area, and polyangular in shape.

After the breakdown of Roman civilization there were few or no important works of either street or road construction for many centuries. Streets in Cordova, Spain, were paved in 950 A.D., at the height of the Moorish power there. The first street pavement in Paris was that laid by order of Philip Augustus in 1185, when the city had a population of 200,000. In the thirteenth century brick pavements were constructed in several cities in the low countries.

The earliest references to street pavements in London are in some acts of Parliament of the fourteenth century providing for paving the Strand. Holborn Street was paved in 1417; and during the sixteenth century some streets outside of the city were paved. The Smithfield market was paved in $\mathbf{1 6 1 4}$. But these were only cobblestone pavements in a few of the most important thoroughfares, while down to the eighteenth century most of the streets were not paved at all, and in rainy weather became great mud-holes. The first pavements in Glasgow were constructed toward the end of the sixteenth century.

In Paris, as early as 1604, paving by the royal government was substituted for the earlier method of requiring householders to pave in front of their property. Under the new system, the cost of construction was levied on the adjacent property in proportion to the frontage, but the cost of maintenance was paid by the government. In 1640 there was a change in the street officials, and a part of the revenues from octroi duties was assigned for street paving. ${ }^{1}$ It is said that in the time of Louis XIII more than half the streets were unpaved, ${ }^{2}$ but in the next half century a large amount of work was done. The Paris pavements were mostly of large stone blocks, eight to ten inches on each side. Granite blocks, even of this kind, were not used in London until

1 Mildmay, Police of Paris, p. 108.

${ }^{2}$ La Grande Encyclopédie. 
1761, when they were introduced in Westminster, and in a few years were generally adopted. About the same time raised foot pavements began to appear in London and Glasgow. ${ }^{1}$ The first foot pavements in Paris were laid in $1782,{ }^{2}$ but they did not become usual for some time. Aaron Burr, writing in 1811, says there were no sidewalks in Paris, ${ }^{3}$ and it was not until 1823 that the construction of footways was required in new streets.

In 1825 there was laid, on Commercial Road, London, a pavement of broad, flat, well-jointed granite blocks for wheel tracks, with pitching between for horses. This method of pavement construction was also in use at this time in Milan, Turin, Verona, Sienna, and other Italian cities. ${ }^{4}$ About the same time a number of stone pavements were built in London, with solid foundations on the plans of the famous road engineers, Macadam and Telford. The blocks were rectangular in shape, but still much larger than those now in use. In 1840 smaller granite blocks, three by nine inches in surface, with mortar joints, were laid on Blackfriars Bridge. The small rectangular blocks afforded a better foothold for horses, and were bonded so as to avoid the continuous edge of the large blocks, which was quickly worn away under heavy traffic. The following shows the various kinds of pavements in the city of London in $1848:^{6}$

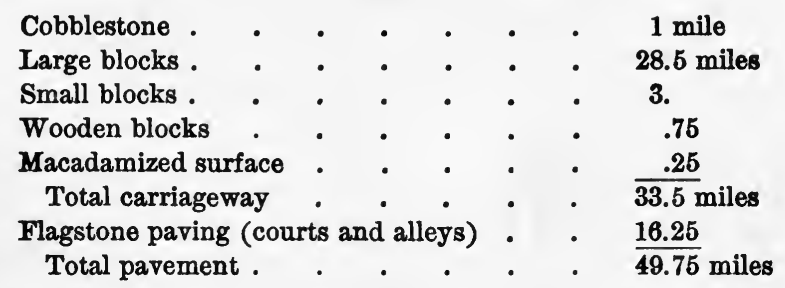

The smaller granite blocks were now adopted generally for all new stone pavements in London. Concrete foundations

1 Bell and Paton, Municipal Glasgow, p. 126.

2 Block, Administration de Paris, p. 347.

3 Tillson, Street Pavements, p. 7.

- Law and Clark, Roads and Streets, p. 209.

6 Ibid., p. 173. 
were introduced in 1872. Wood pavements were also laid to a small extent, being preferred because they were less noisy. After 1870 wood pavements were laid very largely in the districts away from the heaviest traffic.

Some of the other large British cities at once followed London in the use of the new pavements. Glasgow laid a stone tramway, adopted the new granite blocks, and also built some wood pavements. Manchester ceased building cobblestone pavements in 1840 , but they were used in Liverpool for many years later than this. In 1851 Liverpool had 174 miles of carriageways and 69 miles of streets, with an area of $2,474,922$ square yards of carriageways, and 1,048,264 square yards of footways, making a total of 3,523,186 square yards. About two-thirds of this was cobblestone pavement, one-fifth macadam, and only eight per cent of large granite blocks. ${ }^{1}$ The smaller granite blocks were not used in Liverpool until 1871.

In America the first street pavements were constructed in Boston and New York about the middle of the seventeenth century; pavements were laid in Philadelphia and Albany early in the next century; and the first pavement in Baltimore was built in 1781. These were of large rounded pebbles or cobblestones; and in the earliest pavements the stones were laid with a slope toward the centre of the street, forming an open gutter to carry off the surface drainage to the nearest stream. There were no footways. Similar street parements are still to be seen in Spanish and South American cities.

After the Revolution there was apparently an improvement in the construction of pavements in American cities. ${ }^{2}$ Raised footways or sidewalks were built, ${ }^{3}$ and the street surface was made convex instead of concave. Large stone

1 Law and Clark, Roads and Streets, p. 193.

2 Compare Burr's comments on Paris pavements in 1811 - Tillson, Street Pavements, p. 7 : "No sidewalks - the carts, cabriolets, and carriages of all sorts run up to the very houses. . . . Most of the streets are paved as Albany and New York were before the Revolution, some arched in the middle and a little gutter on each side, very near the houses."

${ }^{3}$ Curbstones were first used in Philadelphia in 1786. 
blocks, with a flat surface, but irregular in shape, were used in the streets of St. Louis in 1818; and similar blocks were introduced into New Orleans a few years later, ${ }^{1}$ and into Cleveland in 1851. But in the Eastern cities cobblestones continued to be used almost exclusively for a long time. In 1849 large stone blocks 2 to 3 feet square were laid on Broadway in New York city; and after 1850 the so-called Belgian block of granite, about 8 inches square, was introduced, and in a few years came into general use. Oblong granite blocks were first used in $\mathbf{1 8 6 9}$, but these were about 6 by 18 inches; and it was not until 1876 that the smaller blocks similar to those in London appeared. St. Louis adopted the granite blocks in 1873 , and some are to be found in all large cities, at least on streets of the heaviest traffic. As late as 1884, 93 per cent of the paved streets in Philadelphia were of cobblestone, and only $6 \frac{1}{8}$ per cent of granite blocks. ${ }^{2}$

New York and Philadelphia had some experimental wooden pavements as early as 1835 , but they did not give satisfaction. Many Western cities are, however, located so far from supplies of stone that the cost of any pavement of that material is prohibitive. In consequence these cities have experimented very largely with wooden pavements. From 1844 to 1855 the most important streets of Chicago were planked, in 1851 to 1852 many streets in St. Louis were planked and San Francisco also had planked streets. ${ }^{3}$ Between 1860 and 1870 many cities laid large areas with oblong wooden blocks of pine or spruce. Just after 1870 over a million square yards of wood pavement were laid in Washington; but when this decayed in a few years it was replaced by more substantial pavements. In the West, after 1880 , round cedar blocks came to be used, and millions of yards were laid in Chicago, Detroit, St. Paul, Minneapolis, and many smaller cities. In Omaha, Des Moines, and Kansas City cypress blocks were used.4 The cypress blocks are more durable than cedar, but none of the woods used in

1 Tillson, Street Pavements, pp. 12-13.

2 Ibid., p. 11.

3 Ibid., pp. 11-13.

4 Ibid., ch. 10. 
America are so durable as the Baltic fir used in Europe or the Australian hard woods; while the interstices between the round blocks and the lack of a substantial foundation served to hasten the decay. Wooden pavements have been used to a considerable extent in London, Paris, and Russia, and although more durable than American wood pavements, they require to be frequently renewed.

More recently the use of brick as a material for street pavement has grown to significant proportions. Brick pavement originated in Holland in the thirteenth century, and is still used extensively in that country, as well as in Japan. The first brick pavement in the United States was laid at Charlestown, W. Va., in 1873, followed by one at Bloomington, Ill., in 1875; but it was not until 1883 that brick came into general use. Among the cities which early adopted this form of pavement were Wheeling, W. Va.; Steubenville, O. ; Galesburg, Ill. ; Zanesville, O.; Peoria, Ill.; and Philadelphia.1

Experimental asphalt pavements were laid as early as 1838 . In 1854 a street in Paris was paved with this material; in 1869 it was introduced in London, and in 1873 in Berlin. By 1878 there were 100,000 square yards of asphalt pavement in London, and in 1880, 500,000 square yards in Paris. These European asphalt pavements were constructed with a limestone rock naturally impregnated with bitumen. This material wears very slippery, and consequently has not been used extensively. But with the discovery of natural beds of bitumen, or pitch, notably that on the Island of Trinidad, it was found possible to make an artificial mixture, and by using a granular sand, to lessen very materially the slippery effect. Pavements of this kind have in recent years come to be very largely used in the United States. The first experimental asphalt pavements in America were laid in 1870 in Jersey City and Newark. During the next few years about 20,000 yards of such pavement were laid in several streets of New York, and samples were also laid in Washington, D.C., and Boston. The first extended use was in Washington,

1 Tillson, Street Pavements, ch. 9. 
where from 1878 to 1882400,000 square yards were laid. Buffalo next adopted asphalt paving, and gradually many other cities followed. Since 1890 there has been a very extensive use of asphalt, and the United States now has nearly 30,000,000 square yards of asphalt pavement. Some American asphalt has also been laid in Europe, but as yet a comparatively small amount.

Railway tracks form another kind of street pavement, but the development and comparative extent of these in different cities can best be noted in connection with the discussion on street railway operation, to follow in the next chapter.

Some American cities still have a large area of cobblestone pavement. Baltimore, with over 7,000,000 square yards (most of which was laid between 1874 and 1881), has by far the greatest amount. But in Brooklyn there are still over 4,000,000 square yards, and in Philadelphia, 2,300,000 square yards. The much smaller cities of Cincinnati and Pittsburg have each 1,200,000 square yards, while San Francisco (400,000 square yards), New Orleans (660,000 square yards), and Albany (391,000 square yards) have still a large amount of this pavement. On the other hand, some of the largest cities - notably Chicago, St. Louis, Boston, Cleveland, and Buffalo - have practically no cobblestone pavement.

All of the cities with over 200,000 population, as well as many of the smaller cities, have a considerable amount of stone block pavement. New York has over 9,000,000 square yards of granite blocks, Manhattan Island having been paved almost exclusively with these before the use of asphalt. Philadelphia has nearly 6,000,000 square yards, and Boston nearly 2,000,000 square yards. Chicago has less than 600,000 square yards of granite block pavement, and Detroit only 65,000 square yards, while in the smaller cities of the middle West the small extent of stone block pavement is noticeable.

Philadelphia, with almost 2,000,000 square yards of brick pavement, has the largest amount in any one city; but Des Moines, Ia., with 1,500,000 square yards, leads all the 
American cities in extent of brick pavement in proportion to population. Columbus and Cleveland (Ohio), with $1,600,000$ square yards and 1,200,000 square yards, respectively, rank next. Other cities which have adopted this pavement to a large extent are Louisville, Kansas City, Detroit, Evansville, and Peoria, and most cities in the middle West have a noticeable area of brick pavement.

By far the largest area of wood pavement is to be found in Chicago, where there are $15,000,000$ square yards. Detroit, with 3,700,000 square yards, has, however, a larger proportion of such pavement to the population and to the total area of paved streets. The small city of Superior, Wis., with nearly $1,400,000$ square yards, has wood pavements exclusively. Milwaukee has 1,400,000 square yards of such pavements; Minneapolis, over 1,000,000 ; St. Paul, 559,000 ; and Duluth, 470,000. Some other cities have smaller areas, but brick pavements have already become more common in most cities where wood pavements formerly prevailed.

Nearly every city with over 40,000 population has now some asphalt pavement. New York has nearly 5,000,000 square yards; but the much smaller cities of Buffalo (4,000,000 square yards) and Washington (3,000,000 square yards) have by far the largest area of asphalt pavement in proportion to size. Philadelphia has about $4,000,000$ square yards ; Chicago and Kansas City, each 1,500,000 square yards ; and Pittsburg, 1,000,000. Newark, Rochester, Omaha, and Utica have each a large area of asphalt streets.

Some cities now make large use of macadamized roadways for the residence streets. New York has over 13,000,000 square yards of such streets in the suburban districts; Chicago has 7,000,000 square yards; St. Louis, Boston, and San Francisco each over 5,000,000 square yards; Cincinnati over 3,000,000 square yards; and Oakland (Cal.), Louisville, Providence, and Philadelphia each over 2,000,000 square yards.

So far as one can form a judgment by comparing the records of street paving with the impressions of travellers, 
the best-paved cities in America are, in the order given : Washington, Buffalo, Boston, and the borough of Manhattan in New York. The first two of these are better paved than any other cities in the world, and the other two will compare favorably with the best-paved of the foreign cities. Among the ten largest cities, Chicago has emphatically the worst pavements, with Baltimore only one grade better. Of the other cities with over 100,000 population, those with the poorest street pavements are Milwaukee, Cleveland, Newark, Jersey City, Minneapolis, St. Paul, Denver, Syracuse, St. Joseph, and Scranton.

Statistics of street paving in German cities show a much smaller area of pavement than in American cities of the same population. Hamburg, with $4,000,000$ square yards, has the largest proportion of pavement. Berlin has 6,500,000 square yards; Munich and Leipzig each a little over $3,000,000$ square yards; and Dresden and Cologne each less than $3,000,000$ square yards. These figures are only about one-half of those for cities of the same population in the United States. In quality of pavement none of the German cities equals the best of the American cities; but on the other hand none is so ill paved as the worst-paved cities in this country, and most of them are better paved than the average American city. Most German cities still have some cobblestone pavement, but in no case to any such extent as in Baltimore and Brooklyn. Berlin, with about the same population as Philadelphia, has only about twothirds of the same area of granite blocks, and less than half of the area of asphalt pavement. Hamburg seems to be somewhat better paved than St. Louis, - but with the absence of any large amount of macadamized roads, - while Cologne has better pavements than Hamburg.

The following shows the area of the different kinds of pavement in Paris ${ }^{1}$ in 1894, and in some of the larger German cities ${ }^{2}$ in 1897-1898 :

1 A. P. Rockwell, Roads and Pavements in France, p. 74.

Statistisches Jahrbuch Deutscher Städte, VIII, p. 50. 


\begin{tabular}{|c|c|c|c|c|c|c|}
\hline \multirow{2}{*}{ Cities } & & \multicolumn{4}{|c|}{ Kinds of Pavement } & \multirow{2}{*}{ Total } \\
\hline & & $\begin{array}{l}\text { Granite } \\
\text { Blocks }\end{array}$ & Cobblestone & Asphalt & Macadam & \\
\hline Paris & & $\begin{array}{l}\text { sq. yds. } \\
7,540,000\end{array}$ & sq. yds. & $\begin{array}{l}\text { sq. yds. } \\
402,000\end{array}$ & $\begin{array}{l}\text { sq. yds. } \\
1,724,000\end{array}$ & $\begin{array}{c}\text { sq. yds. } \\
10,550,000^{1}\end{array}$ \\
\hline Berlin . & & $3,200,000$ & $1,600,000$ & $1,600,000$ & & $6,700,000$ \\
\hline Hamburg & - & $1,200,000$ & $2,000,000$ & 100,000 & & $3,900,000$ \\
\hline Munich & - & $1,000,000$ & 40,000 & 6,000 & $2,100,000$ & $3,200,000$ \\
\hline Leipzig . & - & 650,000 & 800,000 & 200,000 & 900,000 & $3,100,000$ \\
\hline Dresden & - & 650,000 & 780,000 & 12,000 & & $2,700,000$ \\
\hline Cologne & - & $1,300,000$ & 320,000 & 42,000 & 560,000 & $3,100,000$ \\
\hline
\end{tabular}

The total area of Paris pavements in 1894 was less than two-thirds the area of Philadelphia pavements at present. There is no cobblestone pavement now in Paris. The stone block pavement covers 7,500,000 square yards, which is 2,000,000 square yards more than in Philadelphia, but the latter city has more than 3,000,000 square yards of asphalt pavement in excess of the 402,000 square yards in Paris.

For the British cities statistics of street paving are not available. The city of London has most of the main streets paved with sheet asphalt. In the metropolitan boroughs, away from the routes of heavy commercial traffic, wood pavements are generally in use, which, like those of Paris, are laid on a solid concrete base, and the wooden blocks are promptly replaced as they wear out. In the large provincial cities granite blocks are largely used, and there is also a good deal of wood pavement. Sheffield shows about the same proportion of paved and unpaved streets as Cleveland.

The factors to be considered in comparing the different kinds of pavement are durability, noiselessness, safety for horses, ease of cleansing, and economy. Some materials are the best in one respect, and others in another respect, while the element of cost often varies for the same paving material in different parts of the country. The granite block is the most durable pavement, and is now recognized as the only

1 Includes 880,000 square yards of wood parement. 
satisfactory pavement for the heaviest traffic. Asphalt ranks next, and if laid on a solid foundation, will stand all but the heaviest traffic. Brick pavements are also satisfactory for streets of medium traffic. Both macadam and wood require constant repairs, but the former, if kept in repair, will last much longer, and is satisfactory for streets of light traffic.

In regard to noiselessness and safety for horses the order of preference is the direct reverse of that for durability. Wood is most satisfactory in these respects, and macadam ranks next. Brick and asphalt are both more noisy and slippery. Granite is more slippery than bricks and less slippery than asphalt; but owing to the exceeding hardness and ringing nature of the stone, the din produced by heavy traffic on a granite pavement is a serious nuisance. On this account it is advisable to pave streets where the traffic does not demand the most durable pavement with other materials than granite; and to make this possible it is important to regulate the street traffic so that certain roads may be used for freighting purposes, and others reserved for lighter traffic.

Judged by ease of cleansing and sanitary advantage asphalt is emphatically the best pavement. The smooth surface can be readily swept, scraped, or flushed, and thus kept free from litter and filth. Well-laid brick and granite pavements are the next best in this respect. Macadam is more difficult to clean, especially in wet weather, and this adds another objection to its use where a considerable traffic, even of light vehicles, adds to the litter in the street. Wood pavements can be cleaned somewhat more easily than macadam, but the decaying wood makes it a source of danger to the public health.

Irrespective of the question of cost, the general statement could be made that the best city pavements would be granite blocks for the streets of very heavy traffic, asphalt for other streets of considerable traffic, and macadam for streets of light traffic. But the high cost of construction for asphalt pavement, and of repairs for macadam, leads to other forms of construction. In New England and southward along the 
Atlantic coast, and in the region adjacent to southwestern Missouri, good stone blocks for pavements may be obtained ; 1 and in these sections the block pavement is naturally used to a large extent. In the basin of the Great Lakes, and in the greater part of the Mississippi Valley, good clays for paving brick abound, and where fuel for burning brick is cheap, that is likely to prove the best pavement, except on streets which receive the hardest wear.

\section{Street Plans}

Many of the ancient cities, especially in the dominion of Alexander the Great and in the Roman Empire, were systematically laid out. This art seems to have been entirely lost after the downfall of Rome. During the Middle Ages cities developed without any well-defined plan or any public control over the direction, breadth, grading, or pavement of streets; and, indeed, up to the nineteenth century most cities were built without any systematic plan. In Paris under Louis XIII some government action was taken to improve the alignment of streets, but even there no comprehensive scheme for the expansion of the city was prepared until the end of the eighteenth century. ${ }^{2}$ One of 1 the earliest of modern cities to be carefully planned was Philadelphiaby Penn in 1681 ; but the plan does not meet the requirements of the present city, and such as it was has no counterpart among the other American cities which date from colonial times, all of which show in their older sections no less an absence of systematic street arrangement than the mediæval cities of Europe.

When at the beginning of the nineteenth century it was determined that a new city should be built as the capital of the United States, a carefully drawn scheme of streets, prepared by a French engineer, was adopted ; and Washington ranks to-day as one of the best-arranged cities in the world. Some years later a municipal commission, of which

2 Block, Administration de Paris, p. 267. 
De Witt Clinton was chairman, determined the street lines for the development of New York city, but the rectangular plan adopted, which now governs the street system of Manhattan Island north of Fourteenth Street, has proven far short of satisfactory. The evils of crooked and narrow streets are avoided, it is true ; but while the great bulk of the traffic, on account of the form of the island, necessarily moves north and south, there are but few streets which lie in those directions, and the large number of east and west streets are not adapted for traffic. Moreover, the absence of any diagonal or radial lines in the plan is only relieved to a slight extent by the persistence of the main highway, now Broadway, which furnishes the only exception to the rectangular system.

Most American cities which have come into existence since the street plan of New York was adopted have been laid out on the same principle, with wide streets crossing each other at right angles, while some of the more recent cities have also diagonal streets, which improve greatly the transit facilities. With the later amendments, this system is fairly well adapted to cities located on a level site; but where the topography is not simple the problems of street alignment become more difficult, and it is only within a few years that the science of street alignment has been carefully studied so as to adapt the street lines to the natural features of the city site. The most prominent examples of street planning on a large scale in a region of complicated topography are in the northern part of New York city and in the southern part of Boston. In both of these cases, while the smaller units are divided by streets which cross each other at right angles, the main avenues are arranged as radials so as to follow the natural lines of traffic to the business centres.

In Europe, also, the alignment of the streets in the new sections of cities is now carefully studied as an important engineering problem, and the opening of new streets is regulated by municipal officials. In the older parts of cities, moreover, where formerly there was no street system, large and extensive schemes of street improvement have, in later 
years, been undertaken, to remedy unsanitary conditions, and to provide adequately for the demands of modern traffic.

The most extensive undertaking of this latter kind has been the reconstruction of Paris in the time of Louis Napoleon. A general plan for improvements had been adopted for Paris at the time of the Revolution, and under the great Napoleon, the restored Bourbons, and Louis Philippe, a number of important thoroughfares had been opened. But a vaster scheme was laid out and carried to completion under the supervision of Baron Haussmann, who was Prefect of the Department of the Seine from 1852 to 1870 . It was at this time that the broad and magnificent radial and encircling boulevards of Paris were constructed through closely built-up districts, and the modern Paris was created. In addition to street improvements, this work included the construction of a water supply and sewerage system, and the opening up of new parks and squares. After deducting the revenues from the sale of building sites condemned for the improvements, the net outlay for the whole series of works was $\$ 250,000,000$. In other continental cities there have been similar, if less extensive, undertakings, and the use of the site of old city walls for an encircling boulevard forms a frequent feature in the improvement. Berlin, Brussels, Antwerp, Florence, Milan, Genoa, Naples, Rome, Hamburg, Lille, Lyons, Toulouse, Rouen, and Geneva are some of the cities which have carried through such works.

In England the most extensive improvement schemes have been those of London. Since 1850 not less than $\$ 160,000,000$ has been spent in the construction of new main arteries of traffic through the great metropolis of the world. ' The most notable work has been the construction of the Holborn viaduct, which carries a great east and west route over one of the leading north and south roads, and thus eliminates the congestion of traffic at the corner of Holborn Street and Farringdon Road. Birmingham and Glasgow have each expended over $\$ 10,000,000$ in similar works, and important improvements have also been carried

${ }^{1}$ Shaw, Great Britain, p. 284. 
through in Liverpool, Manchester, Leeds, Edinburgh, Newcastle-upon-Tyne, and other places. The opening of new lines of traffic, the destruction of unsanitary dwellings, and the improvement of health conditions have been the most important factors in the British reconstruction schemes; and æsthetic improvements, such as mark the works in Paris and other continental cities, have been, in England, of relatively minor significance.

Even in the United States, some of the older towns (notably New York and Boston) have undertaken important street improvements in the older districts to accommodate business traffic and to improve sanitary conditions. The abolition of railroad grade crossings in cities has also involved much street reconstruction, especially in New York, Boston, and Chicago. In New York, over $\$ 8,000,000$ was spent in raising and lowering the tracks of the New York and Harlem Railroad, so as to abolish fifty grade crossings; and the widening and extension of Elm Street has cost over $\$ 5,000,000$. But no comprehensive schemes have been undertaken in this country, such as those of Paris and London. The necessity for the improvement of large areas has been less pressing; legal restrictions prevent municipalities from condemning any more property than is strictly necessary for the street improvements, and thus make improvements more expensive; and American cities obtain no financial aid for such works from the central government, as has been the case in Europe. The result is that the large American cities have no such magnificent avenues through the centre of activities as most of the European capitals have secured from their extensive improvement schemes.

\section{Bridges}

The construction of bridges has always been an important part of road-building, and municipal bridges are in the same way important features in city street systems. But whereas the city streets represent the most highly developed form of roadway, it is highway or railroad bridges rather than 
municipal bridges which represent the highest development in this branch of engineering. Nevertheless, a few of the bridges of the world which are most noted, even as engineering works, are municipal structures, and many other city bridges have also a claim to special attention.

Bridge-building began in prehistoric times. Herodotus mentions one over the Euphrates at Babylon, and bridges are known to have been constructed in Phœnicia, Egypt, and Greece. These early bridges were simple in construction, consisting of piers built closely together, and connected with timbers and planks. The first bridge over the Tiber at Rome - the Pons Sublicius - was of similar construction; but later the Romans applied the arch to bridges, and built a large number of important masonry structures. There were seven bridges over the Tiber, one having a span of eighty feet. High bridges were built to carry the water supply of Rome over low valleys, and many of the municipalities of the Roman Empire also built important bridges. After the fall of Rome there was little bridge-building for several centuries, and almost no progress in the art was experienced until the eighteenth century.

The first stone bridge over the Thames, on the site of the present London Bridge, was begun in 1176 and completed in 1209. The Danube was bridged at Regensburg in 1146; the Rhone at Avignon in 1188, and at Lyons in 1265; the Elbe at Dresden in 1260; the Mosel at Coblenz in 1344; and about the same time the Moldau at Prague was crossed by a bridge which had been under construction for 145 years. Flat arches in place of the Roman half circle were first used in the twelfth century. During the Renaissance period some notable bridges of bold and original designs were constructed. The bridge over the Ticino at Pavia, with seven pointed brick arches, each covering a span of 70 feet, was built in the fourteenth century. At Florence the Ponta della Trinita was built in 1566; and at Venice, the present stone bridge of the Rialto in 1591, the latter having a span of 91 feet. The wooden bridge of Notre Dame was thrown across the Seine in 1433; and in 1604 the Pont Neuf was 
built of stone by Henry IV. About the middle of the eighteenth century the old Westminster and Blackfriars bridges were built over the Thames. In the first part of the next century three other London bridges were built: the new London Bridge in 1817, with three stone arches of 152 feet span; the Southwark Bridge in 1819, with a metal arch of 240 feet span; and the Waterloo Bridge.

A new era in bridge-building dates from the introduction of the modern suspension bridge about 1820. The bridge over the Menai Straits, built in 1819 by Telford, with a span of 570 feet, was the most notable work of the kind up to that time. In 1855 the first Niagara suspension bridge, with a span of 821 feet, was constructed. But the latter, like most of the other important bridges built at this time, was a railroad bridge. The Brooklyn Bridge, over the East River at New York, however, built between 1870 and 1883 , is a municipal work which at the time of its completion surpassed all other bridges in the world, and still ranks among the greatest bridges. It is over a mile in length, with a central river span of 1,595 feet; the roadway is 85 feet wide, and 150 feet above high water; the massive stone piers which support the cables are 278 feet high, and the four cables are each $15 \frac{3}{4}$ inches in diameter. The gross weight of the structure is 17,780 tons, and its cost $\$ 14,627,379$. Another bridge over the East River, even larger than the Brooklyn Bridge, is now under construction. In addition to these New York has a large number of less important bridges. The total number aggregates 440 , but many are small structures. The principal bridges, next to those over the East River, are the seven over the Harlem River, of which the most noted is the Washington Bridge, built between 1886 and 1889, with two steel arches each 510 feet in span.

At London there are now ten bridges under the control of the County Council, and four others (Blackfriars, Southwark, London, and Tower) under the city corporation. The present Tower Bridge, completed in 1897, is an interesting example of a modern bascule bridge. The many bridges 
over the Seine at Paris do not involve any difficult engineering problems, but are noted as successful artistic structures. The most recent is the Alexander III Bridge, completed in 1900. Municipal bridges of considerable size and importance have also been built within the past fifty years over many of the large rivers of Europe. The Rhine is crossed at Mainz, Coblenz, Cologne, and Duisburg-Hochfeld. The bridge at the last-named city, completed in 1896, has two spans of 550 feet. The Danube is crossed at Vienna and Budapest, and the Elbe at Leipzig and Dresden. There are five bridges at Prague, and numerous bridges over the smaller river Spree at Berlin. Glasgow has seven bridges over the Clyde, with several others over smaller streams.

In addition to the New York bridges mentioned above, there are many municipal bridges of some importance in other American cities. The Chestnut Street Bridge over the Schuylkill River at Philadelphia (completed in 1863) is the largest cast-iron bridge in America. The principal bridges at Boston are those over the Charles River to Charlestown and Cambridge. There are many bridges over the Allegheny River between Allegheny and Pittsburg; over the Ohio River at Wheeling and Cincinnati ; and over the Mississippi River at St. Paul, Minneapolis, Dubuque, and St. Louis.

In earlier times tolls were ordinarily charged for the privilege of crossing bridges even when built by public authorities; and some instances of toll bridges in large cities are still to be found. Tolls are charged on vehicle traffic across Brooklyn Bridge, but all other New York bridges are supported from public taxation. In Dresden and Prague tolls are still required. In general, however, bridge tolls have been abolished, and although street car companies frequently pay a considerable part of the cost of bridge construction, as a rule no extra fare is charged for crossing a bridge in a car.

\section{Underground Roads}

In a few large cities the work of street construction has received further development in the building of under- 
ground roads or tunnels of considerable length. These were first built under rivers where bridges were impracticable, such as the Mersey tunnel from Liverpool to Birkenhead, the tunnel under the Clyde at Glasgow, and the Blackwall tunnel (completed in 1897) under the Thames, east of the London bridges. There are also three tunnels under the Chicago River, built mainly for the use of the street railway cars. The most extensive city tunnels now completed are the underground steam railroads of London, built by the private corporations. Glasgow has an underground cable road. In America the most important work of the kind thus far completed is the Boston subway, constructed by the municipality for the street railway traffic. It is twothirds of a mile in length through the heart of the city, and cost $\$ 4,000,000$. A tunnel under Boston harbor to the island of East Boston is now under construction. By far the greatest work of the kind will be the underground rapid transit railroad now under construction in New York city. This is to be twenty miles in length, and is being built, under what is probably the largest single contract ever made, for $\$ 35,000,000$.

\section{SEWERS AND SEWAGE DISPOSAL}

Despite the antiquity of the Cloaca Maxima at Rome and the drainage systems in other ancient cities, the systems of sewerage in modern cities are very largely the work of the last half century. Of the largest cities at the beginning of the nineteenth century, Paris shows the greatest advance in this field. As early as 1412 Menilmontant Brook in the capital of France had been covered - the first measure which went beyond providing gutters and open drains running to the nearest watercourse. ${ }^{1}$ Some other works were constructed during the reigns of Henry II, Henry IV, and Louis XIV; and by the middle of the seventeenth century there were some 12,000 yards of sewers in Paris. In 1740 a

1 The history of early sewer construction in Paris is given in Victor Hugo's Les Miserables, Vol. V, Book 2. 
large connecting canal was built, and small additions were made to the underground drains from time to time, so that in 1806 there were all together 25,480 yards of sewers. Their condition is described by Victor Hugo as "tortuous, fissured, unpaved, crackling, interrupted by quagmires, broken by fantastic elbows, fetid, savage, wild."

About the beginning of the modern era the principal natural drainage course on the present site of London was the Fleet Ditch, formed by the juncture of two smaller streams at Holborn Bridge, whence it ran to the Thames at the present site of Blackfriars Bridge. This stream became choked up with refuse, and in spite of repeated efforts during the sixteenth and seventeenth centuries to clean out the channel, it remained little better than an open sewer. In 1668 Fleet Ditch was again cleaned, and this time its walls were lined with brick, forming a canal 2100 feet long, 40 feet wide, and 5 feet deep at mid tide. In 1733 that part of the ditch north of Fleet Street was filled in, leaving two arches 10 feet high and 6 feet wide as covered sewers to carry off the drainage. In 1760 the remainder of the ditch from Fleet Street to the Thames was filled in and the sewer extended.1 'The only other public sewers in London at this time were Walbrook and the Moorgate sewer - both former watercourses. There were also branch sewers built by private individuals, most of which were constructed after the great fire.

During the reign of George III ${ }^{2}$ the committee of Common Council was created Commissioners of Sewers, with power to construct and repair sewers and to levy local rates. Similar commissioners of sewers were established for other London districts. Under these authorities there was considerable sewer construction. In 1806 house refuse was for the first time allowed in the sewers, and by 1845 there were 15 miles of sewers in the city, 45 miles in the Tower Hamlet district $^{3}$ (of which 11 miles had been constructed since

1 Journal Royal Statistical Society, 7 : 143.

211 Geo. III, ch. 29.

8 Journal Royal Statistical Society, 7 : 143. 
1830), 350 miles in the Holborn and Finsbury districts, and other sewers in other parts of the metropolis. Sewer construction was so far extended by 1847 that in that year the use of cesspools in London was forbidden. The finest sewer at that time - the one leading from Moorfields to London Bridge - was 8 feet 6 inches high by 7 feet wide. All of the sewers at this time discharged into the Thames, although London had now a population of over two millions. Glasgow had begun the construction of public sewers in 1798, and other large British cities had,also built sewers after the beginning of the nineteenth century; but no other city could claim to be even so far advanced as London at the middle of the century.

In Paris the extension of the older sewer system was begun by Bruneseau early in the nineteenth century, but only 5254 yards were laid in the time of Napoleon I, and 18,000 yards additional under the restored Bourbon monarchy. After 1832, however, sewer construction progressed more rapidly, and 97,000 yards were laid in the reign of Louis Philippe, and by 1855 there was a total of 425,000 yards of sewers. ${ }^{1}$

American cities had done very little in sewer construction before 1850. Box drains of wood to carry off surface water had been built in New York as early as 1676, and in Boston before 1700; and a few early sewers were built, most of which were constructed by private property owners. In 1823 the private sewers of Boston were superseded by a system of public sewers built and controlled by the city. When this change was completed, Boston presented a nearer approach to the London standard than any other American city; and twenty years later even New York had no public sewerage arrangements, although that city had then the best and most abundant water supply of any city in the world. ${ }^{2}$ The methods of removing sewage even in the largest cities were the same as those still in use in country districts : kitchen waste was run into the street, and together with the

1 Eclectic Engineering Magazine, 19 : 124.

${ }^{2}$ Hunt's Merchants' Magazine, XII, 53. 
surface drainage either evaporated, percolated into the ground, or was led by open drains to a watercourse; and the contents of privies and water-closets were led to vaults or cesspools, to soak into the soil, or to be carted away as the receptacles became filled.

In 1849 a municipal department of sewers was established in New York city, which was given control over the 70 miles of sewers then within the municipal limits. From that time sewer construction went on steadily, and after 1865 rapid progress was made, until by 1870 there were 260 miles of sewers in New York. Chicago began the construction of public sewers in 1856 ; four years later that city had 56 miles of sewers, and by 1869, 140 miles. $^{1}$ Brooklyn began building sewers on a large scale in 1858, and other large American cities, as well as cities in Germany and elsewhere, soon took up the same work.

The next stage in the advance of municipal sewerage systems began, like the preceding one, in London. The discharge from the sewers, now laden with the fecal matter from a community of two and a half millions, proved beyond the capacity of the river Thames. The filth-laden water became a nuisance; the deposit from the sewers at times obstructed navigation, and was a constant menace to the health of the metropolis. It was obvious that the problem could not be solved by existing authorities, but required a single authority for the entire metropolitan district. To remedy existing evils the Metropolitan Board of Works was created in 1855 . The first task of that board was to build

\section{Sewers in Chicago}

(Board of Health Report, 1867-1869, p. 271)

\begin{tabular}{l|r|c|c|c|c|c|c}
\hline \hline Year & \multicolumn{1}{|c|}{ Feet } & Year & Feet & Year & Feet & Year & Feet \\
\cline { 3 - 7 } 1856 & 31,794 & 1860 & 283,586 & 1864 & 366,723 & 1868 & 582,320 \\
1857 & 57,475 & 1861 & 286,412 & 1865 & 396,671 & 1869 & 730,320 \\
1858 & 159,351 & 1862 & 302,097 & 1866 & 444,798 & & \\
1859 & 213,562 & 1863 & 341,702 & 1867 & 534,479 & & \\
\hline
\end{tabular}


a series of intercepting or trunk sewers, converging into two sewer tunnels, one on each side of the river, which were extended to a point of outfall in the river some fifteen miles below the city. The outfall sewers were opened in 18631864 , and were in full operation by $1866 .^{1}$ The original plan was to provide temporary storage, and to discharge each halfday's accumulation on the ebbing tide. But in times of rainfall the storage system proved inadequate, and caused a backflow of sewage, which overflowed into the streets at many places. To remedy this a system of relief sewers was built leading directly into the river, thus discharging, whenever there was a heavy rainfall, a large amount of sewage into the Thames directly within the metropolis. This was manifestly little improvement over the old system. Moreover, a royal commission reported in 1884 that the discharge of crude sewage into the river, even at the end of the outfall sewer, should not be allowed. To provide a remedy for the first of these difficulties, additional pumping and tunnel facilities were constructed. For the second, a system of precipitation by chemical treatment was adopted; the effluent was discharged into the river, and the sludge was carried away by steamers and deposited at sea. ${ }^{2}$

In Paris the reconstruction schemes of the second empire included a radical extension of the sewerage mains on a well-planned system, and in addition the main features of the London works which had been already begun. The 90 miles of sewers in 1855 had increased by 1878 to 450 miles, or but 50 miles less than the total mileage of streets at that time. Three intercepting trunk sewers have also been constructed, ${ }^{3}$ one on each bank of the Seine, and a third across the northern part of the city. These trunk sewers are each from 5 to 7 miles in length, 10 feet high, and from 15 to 20 feet in diameter. The sewage ordinarily flows in a channel 4 or 5 feet deep, on either side of which is a footway 2 or 3 feet wide. Since 1878 the work of extending the

1 Eclectic Engineering Magazine, 19 : 124.

2 Shaw, Great Britain, 263-275.

3 Block, Administration de Paris, p. 486. 
Paris sewers has progressed steadily, and the aggregate length of the sewers reported in $\mathbf{1 8 9 6}$ was 722 miles. The discharge of the Paris sewage into the Seine just below the city was less obnoxious than the similar deposit of London sewage into the Thames, because in Paris house sewage was not allowed in the sewers. Nevertheless, since 1870 the purification of the sewage by means of broad irrigation has been tried on a large scale. In recent years cesspools are being abolished, and all sewage is being led into the sewers. It remains to see whether the present methods of treatment are adequate for the new conditions.

Since 1870 the problems of final disposal of sewage, before that date confined mainly to London and Paris, have been seriously met in many other cities, notably in Great Britain and Germany. Birmingham, Manchester, and Glasgow were among the earliest British cities to undertake such works. In Germany Danzig inaugurated a complete sewerage system with a sewage farm in 1869. Berlin began a comprehensive scheme in 1870, and by 1875 had the new works in operation over a considerable part of the city.

At the present time the British cities are the best equipped in this branch of municipal activity, a situation due in part to the early development of the urban conditions, and in part also to the pressure of the Local Government Board on any local authorities who were inclined to neglect this work. In many British cities, however, the sewers are connected with water-closets in only a part of the houses. Even in Birmingham only half of the population is supplied with water-closets connected with the sewer system.

Most of the large American cities have sewers in a large part of their built-up area; but there are some important exceptions. Baltimore, New Orleans, and Mobile have practically no underground sewers, and the surface flow is allowed to run off in the open gutters. In other cases the sewer system has not been extended with the growth of the city. Philadelphia in 1900 had but 886 miles of sewers to 1400 miles of streets; and St. Louis only 495 miles of sewers to 875 miles of streets. In many cases, too, sewer construction 
has been an accidental growth, with no well-defined plan. Thus the New York sewers down to 1880 had 80 openings south of Fourteenth Street, all ending at the bulkhead line, allowing the discharge to accumulate between the piers. Philadelphia sewers still discharge into the Schuylkill and Delaware rivers all along the city front, and cesspools are still allowed in the city. In Chicago the sewer grades are almost level, and on account of the difficulty of cleaning them kitchen slop has not been allowed in the sewers. Other cities present similar examples of haphazard development. Nevertheless considerable improvements have been made in several American cities within the last twenty years. In New York intercepting sewers have been constructed along the water front, discharging into the swift tidal current at the outward end of the piers. In Manhattan and Bronx there are over 400 miles of sewers discharging at 140 outlets, the area being divided into 26 distinct drainage districts. In Buffalo the construction in 1882 of an intercepting sewer 4 miles long and 8 feet in diameter has relieved the most serious difficulties there. Washington is well sewered, with an aggregate mileage of sewers 125 miles greater than the street mileage. In Memphis there is a double system of sewer pipes (introduced after the yellow fever epidemic of 1878), one set for the surface drainage and another for household waste. A few other cities in the United States have also adopted this "separate" system.

In Germany all of the cities of over 50,000 population have a sewerage system, and in most cases this extends to practically the whole populated area. Munich and Hanover, however, are notable exceptions to this rule. In Bremen, Dresden, and Cologne, moreover, and indeed in more than half of the large German cities, the sewers do not carry off the contents of privies. The cities of Holland are well sewered. Amsterdam, Leyden, and Dordrecht in Holland, and Prague in Bohemia have each adopted the separate pipe system, and use the Lierneur pneumatic system for fecal matter. In France only the largest cities have even good systems of storm-water sewers, and so large a town as Bor- 
deaux has but 60 miles of sewers as compared with 240 miles of streets, while Havre as late as $\mathbf{1 8 9 4}$ had practically no sewers. The use of the Paris sewers for household waste has recently been extended, but comparatively little has yet been done in this direction. In other countries complete sewerage systems are still exceptional. Among the recent constructions may be mentioned those at Rome, Riga, and Moscow. At St. Petersburg wooden drains are still used, and in many other cities primitive methods of sewage removal are even yet in vogue.

\section{Final Disposal}

Until very recently sewers were built only to carry drainage and waste matter outside of the densely inhabited area, beyond which reliance was placed on natural drainage ; but with the continued growth of urban population the question of final disposition of sewage has demanded further attention in many places. If a city is near a large river with swift currents, as in the case of New York, Milan, Rome, Vienna, and Budapest, simple discharge into these waters is still considered adequate. If the current is not swift, but a large body of water is near at hand, the construction of intercepting and outfall sewers generally meets the emergency. Such works have proved effective abroad at Liverpool, Bristol, Brighton, and most English coast towns. In this country the most prominent examples of the system are the outfall sewers, for the metropolitan district in eastern Massachusetts, and the Chicago Drainage Canal (30 miles in length, and built at a cost of $\$ 30,000,000)$, the most gigantic sewer in the world. For inland towns, however, such systems are impracticable, and other steps are necessary to prevent unsanitary conditions. The following are the principal methods now used at inland towns: 1, broad irrigation; 2, intermittent filtration; 3, mechanical filtration; 4, mechanical subsidence; and 5 , chemical precipitation.

Broad irrigation consists in passing the sewage in its 
crude stage over large tracts of agricultural land, called sewage farms. The system is used in Berlin, Breslau, Bremen, Brunswick, and a few other German cities, and also in some English towns, such as Rugby, Leamington, and Blackburn. In the United States, it has been adopted at Los Angeles, Colorado Springs, and at a few smaller Western cities, where the need of water for irrigation is an important element in deciding the choice of a sewage disposal system.

Intermittent filtration consists in passing the sewage over small tracts of land previously prepared by deep drainage. This method is used at Merthyr Tydvil, in Wales, and in this country at Lawrence and South Framingham, Mass.

Mechanical filtration is used at Altoona, Pawtucket, and Taunton. Sewage disposal by means of mechanical subsidence has proved to be very unsatisfactory, but is in use at Munich and Posen.

The purpose of chemical precipitation is to accelerate the subsidence of solid sewage. It was first tried at Paris, in 1740, but new chemical processes have since been discovered, and most precipitations now in use are of recent origin. Chemical precipitation is employed at London, Glasgow, Manchester, Sheffield, Leeds, Nottingham, Salford, and many other British towns; at Frankfort, Leipzig, Dresden, and a few other German cities; at Munich and Posen; and at Worcester (Massachusetts) and a few smaller places in the United States.

Two important questions in regard to street and sewer construction are : 1 , whether the work is done by a municipal corps of employees or by a contractor; and 2, the method of meeting the cost.

The general rule in regard to the first question is that the construction of new works, large reconstruction schemes, and extensive repairs are made by contract. Ordinary repairs are often made by a force of city employees, but frequently street pavement contracts require that the pavement shall be kept in repair for a stipulated number of 
years by the contractor. There are, however, a few notable instances where municipal public works are executed directly by the public authorities. The Works Department of the London County Council is probably the most prominent example of such public activity. This acts as a contractor to the various other committees of the council; has a force of engineers, draughtsmen, and laborers ; submits estimates for projected works ; and undertakes the construction of such works as are assigned to it. From the organization of this department, in 1898, to March 31,1899 , it executed works amounting in value to over $\$ 4,000,000$. Other English towns which exercise municipal control over construction work are Liverpool and Birmingham. The most prominent example of direct city construction work in the United States is in the street department of Boston.

In most countries the general rule for distributing the expense of street improvements is to require the abutting property owners to pay for the cost of the original improvement, including grading, paving, and drainage. In Great Britain the municipalities accomplish this by refusing to accept a street as a public way until it has been put in satisfactory condition. In the large cities of the United States the work is usually carried out under the supervision of the municipality, and the cost is collected from the property owners by special assessments. This is the system adopted in New York, Philadelphia, Baltimore, Buffalo, Milwaukee, and St. Paul. ${ }^{1}$ In some cases, however, the city pays part of the expense out of the funds received from general taxation. In Cincinnati the city pays 2 per cent for the less improved streets, and one-half for the streets paved with granite or asphalt. In St. Louis, if a street assessment exceeds 25 per cent of the assessed value of a property, the city pays the excess. In Boston the city pays the entire cost of street construction. Betterment assessments can be levied against the property benefited, but in practice these are offset by land and grade damages. The special assessment method also is used in the United States for reconstruction

${ }^{1}$ Engineering News, 28 : 281. 
schemes. In Europe part of the cost of such schemes is usually met by the purchase of the property through which the street runs, and the re-sale of what is not used at the enhanced value due to the improvement. In France, Italy, and other South European countries, paving expenses, including one-half of the cost of sidewalk construction, are usually borne by the municipality out of its general revenues. In some cases the central government has aided very largely, notably in the Paris and Berlin improvements.

The expense of maintaining streets is, in general, borne by the municipalities from the proceeds of general taxation. Usually, too, the city pays the cost of replacing a worn-out pavement; but in St. Paul and Buffalo the property owners are required to pay for repaving as well as for the original pavement, and in Baltimore two-thirds of the cost of maintenance is assessed on the property owners, in proportion to the frontage of property abutting on the streets.

\section{SCAVENGING}

Brussels seems to have been one of the first of modern cities to organize the work of scavenging. The present dumping grounds were in use as early as 1560. In Paris during the eighteenth century the government made contracts for street lighting and for removing refuse. Each householder was required to sweep his refuse into heaps; the city swept only the public squares and a strip in the middle of wide streets. In 1763 there were 120 carts used in the work of scavenging. The expense of street cleaning at this time was $\$ 50,000$.

During the first part of the nineteenth century the street cleaning in Brussels was done by a contractor who paid the city for the privilege. The municipal revenue from this source was 6960 francs in 1836, and 26,940 francs in 1846 . About 1853 the city undertook the work of scavenging directly, and the profit in 1856 reached 75,505 francs. Soon, however, the revenue began to be reduced by the removal of the contents of house closets - the most valuable refuse - 
through the sewers; and at the same time the expenditures: were augmented by the increasing standard of cleanliness and the longer hauls for final disposition; in consequence of which the outgo shortly became more than the income. Only two years after the date just mentioned there was a net outlay of 11,950 francs, and by 1865 this had risen to 102,000 francs. This situation led to a brief renewal of the contract system - the city this time paying the contractor, 1 - but the work was poorly done, and in 1871 it again became a municipal undertaking. In 1853 the city of Paris undertook to do the work of street-sweeping for those householders who voluntarily made an arrangement with the municipal authorities; and by 1873 more than half of the streets were cleaned by the city under such private agreements. In that year the city undertook to do the whole work, and made the assessment obligatory on all householders.

Colonel George E. Waring, Jr., in Street Cleaning and Its Effects, describes the present systems of street cleaning in the principal cities on the continent of Europe, and also in London and Birmingham. Not only the towns named by him, but all of the German cities of over 50,000 population, have a municipal street-cleaning department, and also a street-sprinkling force. Düsseldorf (population 170,000) is the largest place where the entire street-cleaning work is still a duty of the householders. The Berlin force of 1000 men and 200 sprinklers is of course the largest, but some of the smaller cities have a much larger per capita force; for example, Strasburg (220), Hanover (225), Bremen (150), Cologne (315), and Dresden (350). Breslau (116) and Munich (53) have the smallest street cleaning and sprinkling force in proportion to population.

The English towns all undertake the work of street cleaning, and in most cases domestic scavenging (removal of garbage) is also done by the municipality. Some towns go even farther. Out of 90 towns, 13 remove trade and garden refuse as well as house garbage without extra charge, while several other towns perform the additional service for those

1 The amount paid was 81,000 francs. 
who pay a special tax. Of the same 90 towns, 19 cleanse the private courts and alleys in addition to the public streets. ${ }^{1}$

Of 85 towns, 70 employ their own staff for the collection of the refuse; 2 have a municipal force, but also employ a contractor for a part of the work; and only 13 are entirely dependent upon contractors. ${ }^{2}$ For the final disposal of refuse, a number of the larger towns have now "dust destroyers," or garbage cremators. The first cremator was built at Leeds, where a second one has since been erected; while others have been established at Liverpool, Bradford, Nottingham, several London districts, and also in smaller towns. The following table gives the number of cells, height of chimney, daily capacity for refuse, and cost of the refuse destroyers in some of the English cities : ${ }^{3}$ -

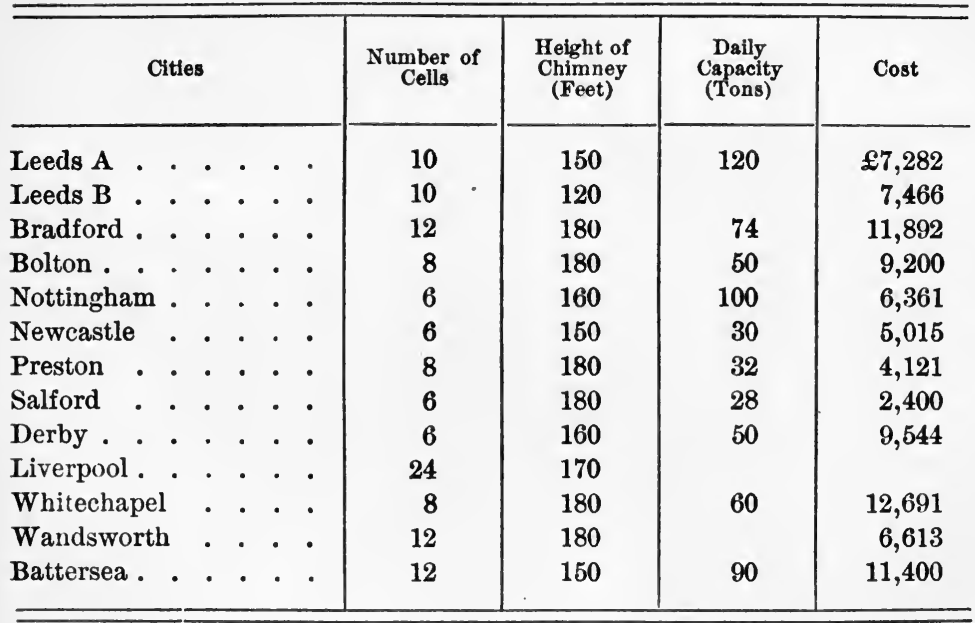

Municipal street cleaning was begun in Glasgow on a small scale in 1800 ; but the present cleansing department was organized in 1868. It consisted in 1896 of 1089 men, with 405 vehicles and 265 horses. The principal streets are swept nightly, and are also "picked" during the day, the

1 Boulnois, Municipal and Sanitary Engineer's Handbook, pp. 259, 276.

2 Moore, Sanitary Engineering, p. 130.

8 Boulnois, Municipal and Sanitary Engineer's Handbook, p. 267. 
"pickings" being placed in bins sunk in the pavements, and removed at night. Second-class streets are swept every other night, and streets of less importance at longer intervals. Private streets and courts, as well as public streets, are cleaned by the municipal force. Every court is swept at least once a day, and the dirtier courts are regularly hosewashed. Refuse from residence and business houses, and excremental matter from dwellings not furnished with waterclosets, are also removed by the cleansing department. A refuse destroyer disposes by cremation of part of the material collected; but the larger part - 1000 tons a day - is used as manure. The city owns some 900 railway cars for transporting this. About 60 per cent of the manure is sold to farmers, and is conveyed to farms sometimes seventy miles away from the city; the remainder is used on farms owned by the city department. The total investment of the city in works and plant was in $1896 \$ 1,200,000$. The total expenditure was $\$ 550,000$; revenue, $\$ 170,000$; special assessments, $\$ 60,000$; leaving $\$ 320,000$ to be paid from the general revenue of the city. ${ }^{1}$

Turning to the United States, the municipality of New York has spent considerable sums for street cleaning since the middle of the century. After 1866 the work was under the supervision of the Board of Health ; in 1873 the authority was transferred to the Police Department; and in 1881 a separate department of street cleaning was created. But despite the change in organization and constantly increasing expenditures, the work continued to be very poorly done until the administration of Colonel Waring, beginning in 1895. In 1894 there were 1275 sweepers and 908 drivers. Under the direction of Colonel Waring the number of sweepers was increased to 1400 , but the improvement in the quality of the work done was far more than commensurate with the increased number of laborers; and so far as concerned street sweeping proper, the improved condition of the streets was due mainly to better discipline of the force and the application of business methods. One of the most

1 Bell and Paton, Municipal Glasgow, Ch. 16. 
important achievements under the supervision of Colonel Waring was the great increase in the area of streets cleared of snow by contract. In this field the improvement was not simply the more efficient execution of work already undertaken, but was an increase in the scope of municipal action with a corresponding increase in expenditure.

Even before the time of Colonel Waring, street cleaning was a more important municipal work in New York than in any other American city, and it still remains far ahead of other cities. In all the boroughs of the extended city there are now employed a total of 3600 men as street sweepers, and 1500 men as garbage removers. The final disposition of garbage and street refuse in New York is performed by contract. The bulk of the refuse has been carried out to sea or used for filling in low lands; a small proportion is utilized at works on Barren Island. ${ }^{1}$ Street sprinkling in New York is not a municipal function.

1 NEW YORK STREET CLEANING DEPARTMENT

Cart loads of Refuse Collected, 1898

City Record, May 29, 1899

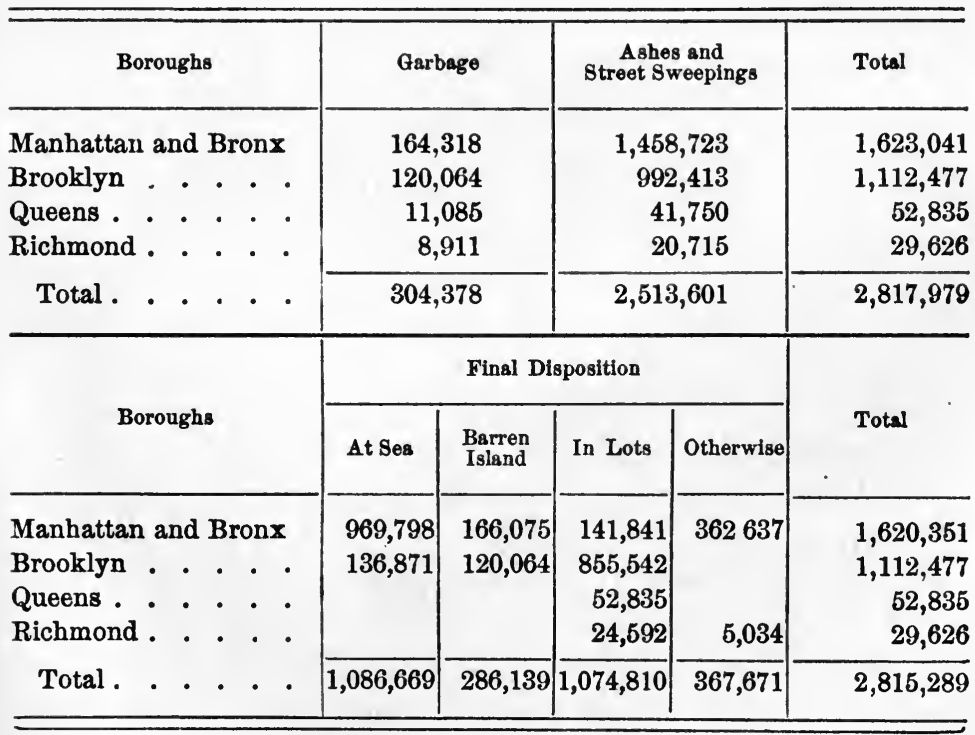


In most of the other large cities of the United States some part of the streets is swept at public expense; but in general the size of the force employed indicates that a comparatively small amount of work is done. St. Louis, the fourth largest city in the United States, employs but forty men for street cleaning. The cities with the largest number of men are Chicago (675), Pittsburg (485), Washington (388), Boston (370), and Cincinnati (300). For the removal of garbage Boston employs 600 men; Chicago, 460 ; and Washington, 250. This work is still done by contract in a number of the largest cities, as Philadelphia, St. Louis, Buffalo, Cleveland, Columbus, and Indianapolis. Indeed, New York, and, to a smaller degree, Chicago, Boston, Baltimore, and New Orleans, are practically the only large towns in which a municipal force undertakes this work. The smaller American cities still depend largely on the householders for the removal of garbage. In the United States street sprinkling is usually done by private arrangements with property owners.

\section{PUBLIC BATHS}

The destruction and decline of the ancient cities in the Roman Empire brought with it the ruin of the magnificent public baths; and not until the last half of the nineteenth century do we find the faintest attempt at similar establishments. Open-air bathing places in streams and lakes have, of course, existed near every town, and the management of such places by the municipalities in German cities dates at least as far back as the thirteenth century. But it was not until the middle of the nineteenth century that enclosed bathinghouses were put in operation. The movement began in London, and has been most active in Great Britain and (since 1866) in Germany. Almost every British town of over 50,000 inhabitants (to be exact, 58 towns out of 65) have now municipal bath-houses. In London there are 30 establishments; in Manchester, 9; in Liverpool, 8; in Glasgow, 7 ; in Newcastle, 6 ; in Birmingham, 5 ; and in Bristol and Salford, each 4 . In a few cities, as Liverpool, London, and Glasgow, there are also public wash-houses, 
where family washing may be done. Besides the large cities, many of the smaller English boroughs have built public bath-houses. Among the German cities, there are municipal baths in 40 out of 55 places with a population of over 50,000, and also in smaller cities. In other countries, municipal baths may be found occasionally in the larger cities. Paris, Bordeaux, Lille, Roubaix, Rheims, Vienna, Budapest, Prague, Rome, Stockholm, all have public baths. Of the cities without public baths, the most prominent are Marseilles, Rouen, Nice, and St.-Étienne.

In the United States municipal baths are very uncommon. Even open-air baths were not under municipal management until about thirty years ago, when Boston assumed such control ; but in most of the larger cities, the open-air baths are now found to be under the management of the municipalities. The first enclosed municipal bath was established at Yonkers (New York), in 1894, and since then enclosed baths have been built at Chicago, Boston, Buffalo, Providence, Brookline, and Worcester.

In comparing the number of public baths in America with that in European countries, it should be remembered, first, that in the American cities the private houses contain baths to a very much larger extent than in Europe; and second, that in Europe those who use the baths pay fees which nearly or quite meet the expenses of operation, whereas in the United States, where municipal baths have been established, they are in nearly every case supported from general taxation.

\section{PARKS AND PLAYGROUNDS}

Before the nineteenth century, the only public parks in or near large cities were those established and maintained by royal estates. Thus in the Westminster district of London there were St. James and Hyde parks, which had been Crown property since the time of Henry VIII. ${ }^{1}$ To these was added,

1 Hyde Park originally belonged to Westminster Abbey, but came into the possession of the Crown on the dissolution of the monasteries. In 1652 it was sold by the Commonwealth government; but at the Restoration in 1660 it was repurchased, and under Charles II, St. James's Park was extended. 
about 1815, Regent's Park, to the north of the other two. In Paris, the royal gardens at the time of the Revolution included the Tuileries, Luxembourg, and the Jardin des Plantes. The tract now forming the Bois de Boulogne was also reserved by an edict of Louis XIV in 1679; but in common with other more distant parks was too far from the population centres to be effective as urban resorts. In 1828 the strip of land to the north of the Tuileries gardens was transferred to the municipality, and the Avenue des ChampsÉlysées was laid out and constructed on an elaborate plan.

Important additions were made to the London open spaces by the formation of Victoria Park in 1842 and Battersea Park in 1852. The Metropolitan Board of Works, established in 1855, was given the management of some of the existing grounds, and also established a number of new public parks. A few other British towns made some advance in this direction about the same time. At Liverpool, the first large public ground was Prince's Park, opened in 1843. Wavertree Park was added in 1858. In Leeds the grounds of Woodhouse Manor were opened to the public as a municipal park in 1857. Five years earlier the Bois de Boulogne and other government grounds in Paris had been transferred to the municipality, and in 1860 the Bois de Vincennes constituted a new accession. To these and other parks extensive improvements were made, including driveways connecting the outlying parks with the centre of the city, in connection with the other great works of the Haussmann period.

The park movement in America is of much later date. The New England towns had each in the earlier days a considerable tract of common land; but these tracts were generally sold to private holders, and only in the case of Boston Common was any considerable park area left in the heart of a large city. In 1812 a few acres of land were purchased for a park in Philadelphia; but this was merely the nucleus for the present Fairmount Park in that city. Legislative authority for a large park on Manhattan Island was given in 1851, and seven years later the work of preparing the now famous Central Park of 860 acres was begun. In 1860 the 
city of Baltimore acquired a private estate of 700 acres, which was formed into Druid Hill Park.

These were the only well-developed parks in the United States in 1870. Since then, however, all of the important cities have made provisions in this direction. In 1869 Boston began the preparation of Franklin Park; by 1886 twenty cities had large park areas; and since that time municipal parks have increased with wonderful rapidity. During the last two decades the large British and German cities have also very generally entered actively in this field. The cities of other countries are participating in the general interest in parks, though to a smaller extent.

The recent park movement has included many features, in addition to the provision for large reservations, with drives, gardens, lawns, terraces, and woods. In the European cities the sites of the old fortifications, rendered useless by the growth of the cities, have been utilized for broad parked avenues, or boulevards, ${ }^{1}$ - a name which has also been applied to other tree-lined avenues constructed as a portion of the park system of the cities. In America, Chicago led the way in the construction of similar boulevards uniting the various parks into a connected system. Another feature in the recent development has been the provision for many small parks or public squares scattered throughout the congested districts. In this field the German cities have accomplished most. In both small and large parks, provisions have been made in many cities for outdoor sports; and in some instances well-equipped park gymnasiums are in operation. More exceptional, but growing in number, are instances of scientifically arranged botanical gardens and zoölogical museums.

Paris has by far the richest park equipment of any city in the world. The total area of parks within an afternoon's excursion of the city is 20,000 acres, while farther away are still more extensive public grounds, such as Versailles and Fontainebleau. The most important of the near-by parks are the Bois de Boulogne and the Bois de Vincennes, each with

1 A corruption of the German "Bollwerk" (bulwark). 
an area of over 2200 acres, which cost for original establishment nearly $\$ 8,000,000$. Of the smaller parks the most important are the Buttes-Chaumont of 62 acres and the Montsouris of 45 acres, the former located in the northeastern part of the city and the latter in the south. There are all together nearly a hundred squares, parks, and gardens throughout the city. In addition there are numerous broad, tree-lined boulevards under the control of the park authorities, the most noteworthy of which are the Avenue des ChampsÉlysées and the Avenue de Bois de Boulogne, from the centre of the city to the park. The Jardin des Plantes, maintained by the central government, is mainly a botanical and zoölogical garden.

The parks of London stand next in importance to those of Paris. The County Council now controls 18 parks, 39 gardens and playgrounds, and 30 small open spaces, with a total area of 3814 acres. The city corporation maintains 10 city commons, as well as Epping Forest, which comprises 6500 acres. In addition there are half a dozen large royal parks and numerous small green spots maintained by the local authorities. The total park area within the metropolitan district is over 13,000 acres. Within a six-mile radius of Westminster Bridge there are 5300 acres of parks; but nearly two-thirds of this lies to the west of the bridge; and there are still large sections in the eastern part of London with no important parks. The arrangements for games and sports in the grounds under the control of the County Council are especially notable: there are 385 cricket pitches, 466 tennis courts, 45 skating ponds, 4 golf links, 4 lacrosse fields, 4 bowling greens, 6 gymnasiums for adults and 32 for children.

In the United States the most extensive park system is that for the metropolitan district in eastern Massachusetts. Under the control of a state board there are now 8 parks from 24 to 4200 acres in extent, aggregating 8090 acres; 10 miles of parkways along the Charles, Neponset, and Mystic rivers; and a large bathing beach at Revere on the seacoast. The principal park reservations are Middlesex Fells, to the north of Boston, and the Stony Brook woods and the Blue 
Hills to the south. Besides these most of the cities and towns within this district have also important park systems. The city parks of Boston include 2360 acres, with 125 acres of ponds and rivers and 34 miles of driveways. From the Public Garden the broad tree-lined boulevard known as Commonwealth Avenue extends to the Back Bay Fens; and from there a series of parkways unites the various city parks, ending at the Marine Park on the shores of the harbor. In this chain of parks are the extensive botanical gardens of the Arnold Arboretum, owned by Harvard University, but open to the public. Boston has also the first open-air gymnasium established in a public park, at the Charles River Embankment.

The various parks of New York city aggregate nearly 7000 acres; but with the exceptions of Central Park on Manhattan Island and Prospect Park in Brooklyn, the large reservations are in the distant outskirts of the city. There are no parked boulevards into the heart of the city such as Conmonwealth Avenue in Boston. Riverside Drive along the Hudson River is the most accessible boulevard, and is probably the most beautiful parkway in the world. More distant are the Ocean Parkway and Bay Ridge Shore Drive in Brooklyn, and the new boulevards under construction in the borough of the Bronx. One of the northern parks is divided into a large botanical garden and a zoölogical park, each of which is under the immediate control of a private society. Along the Harlem River there is a two-mile speedway for fast driving, constructed at a cost of $\$ 3,000,000$. The number of small parks has been very limited in New York, but within recent years several new ones have been constructed. Some of these are equipped with gymnastic apparatus, while the larger parks have provisions for outdoor sports. A special feature of New York open-air arrangements are the recreation piers along the water front. The main floor of these piers is left for ordinary commercial purposes; but the second floor, which has a roof but no sides, serves as a recreation space, and is a favorite resort on hot summer evenings. 
Philadelphia has over 4000 acres of parks, and Chicago and St. Louis each over 2000 acres. The Chicago parks are linked by nearly forty miles of boulevards, the most popular of which are the Midway Plaisance and the Lake Shore Drive. There are practically no small parks in Chicago. Washington has 3600 acres of parks, and with its broad avenues, which have a parkway aspect, is by far the best equipped, in proportion to population, of any city in America. In addition to large parks, Washington has its botanical gardens and an abundance of small park areas. One of the principal systems now under construction is that of Essex County, New Jersey, which includes the city of Newark and a large number of suburban cities. The area of parks in this system is about 2500 acres.

All of the other American cities of over 100,000 population, with the exception of Jersey City and St. Joseph, have large parks, and most of the cities of over 40,000 population, and some smaller cities, have at least acquired lands for park purposes. The Lynn Woods in Massachusetts and the parks of Los Angeles, Cal., deserve special mention among cities not in the metropolitan class. New Orleans is better provided with parked avenues than any other American city. The original plan of that city provided for a number of broad streets (notably Canal Street, 200 feet in width), and these have recently been furnished with park features. Minneapolis and St. Paul are noted among the Western cities for the number of small parks. Buffalo and Pittsburg have botanical gardens, and most of the large cities have flower displays in the public parks.

Outside of Paris and London, the cities of Europe have generally a smaller park area than American cities of the same size. In Great Britain, the best-equipped places are Newcastle (1270 acres), Glasgow (1000 acres), Leeds (660 acres), and Norwich (600 acres). Liverpool has only about 600 acres, Birmingham but 360 acres, Manchester and Nottingham each 300 acres. The park areas are, however, usually well distributed throughout the cities. Most of the large cities, too, have a number of small playgrounds; 
Glasgow has 13; Manchester, 24; Leeds, 16; Salford, 17; and Newcastle, 13. Municipal botanical gardens are provided also in Glasgow, Leeds, Sheffield, Nottingham, and Cardiff, in addition to which there are large government gardens at Kew, Edinburgh, and Dublin.

Berlin has the largest extent of parks of any German city. The total area within the city limits is about 1100 acres, about one-third of which is municipal, while the municipality also owns two large parks in the outskirts. Munich has about 1100 acres of parks; Magdeburg, 600 acres ; Dresden, 560 acres (mostly in government parks); Breslau, 350 acres; and Hamburg, 300 acres. Other German cities have a much smaller park area. Frankfort-on-the-Main has less than 90 acres, while Altona, Crefeld, and Essen have each less than 50 acres. On the other hand, the German cities are well endowed with parked boulevards and small park spaces. Hamburg has over 100 miles of tree-planted avenues ; Dresden, 90 miles; Berlin, 65 miles, including the famous Unter den Linden; Munich, 35 miles. Berlin has over 100 open spaces; Munich, 62 ; Hamburg, 58 ; and Dresden, 48.

The cities of Holland and Belgium, as well as those of France (Paris excepted), resemble the German cities with respect to park arrangements. Boulevards and small parks and squares are more strongly emphasized than large rural parks. Brussels has a good-sized park, and Marseilles has a park of 400 acres ; but Roubaix has only 90 acres, and Brest only 40 acres, while Toulon and Dijon report no parks. In other European countries, only a few of the largest cities have extensive public parks. St. Petersburg has 350 acres ; Stockholm, 160 acres ; and Copenhagen and Geneva, about 100 acres each. Rome is the only Italian city where municipal parks are under way. Milan has but 3 acres of public parks, and Bologna only 8 acres. The cities in these countries (Russia, Switzerland, Italy, etc.) have, however, many public squares, or places, and boulevards, as the Prado at Madrid, the Prater in Vienna, and Andrassystrasse in Budapest. In the outskirts, too, there are usually large parks attached to the villas of ancient families, which, 
in some cases, are open to the public on certain days. Botanical and zoölogical gardens in the European cities are not, as a rule, under municipal management, but under the control of the central government.

The management of parks in American cities is nearly always under the control of a special board, either locally elected or appointed by municipal authority. Such park boards are found even in Boston and Cleveland, where single-headed departments are the prevailing system. Usually the park boards consist of from three to five members, but in Buffalo there are fifteen commissioners. Chicago has three separate boards for the parks in different sections of the city. In New York city there are three park commis- . sioners, each of whom has jurisdiction over the parks in a certain district. St. Louis has a single park commissioner.

In almost every case the park boards are independent of the other authorities having control over municipal improvements. Only in St. Louis is the park commissioner made a member of the municipal board of public improvements. The independence of the park management from the other branches of municipal administration is emphasized in the case of state-appointed boards at Chicago, the Massachusetts metropolitan park commission, and the commission for the proposed interstate park along the palisades of the Hudson River.

\section{PUBLIC WORKS ADMINISTRATION}

For the management of other public improvements the more general system in American cities is a board of water trustees controlling the waterworks, and a board of public works directing the work of street paving and sewer construction. But the tendency toward single-headed departments in cities is growing, while a few places have taken some steps toward the establishment of one general authority over all the public improvements. Thus, Chicago has had since 1876 a single commissioner of works, who has control over street paving and cleaning, sewers, the water-supply 
service, the river and harbor, and public buildings; but there are also a board of local improvements and the Sanitary District Trustees. Boston has a single superintendent of streets for streets, bridges, fences, and sewers, and a single water commissioner; but each has charge of a distinct department, while there are separate boards which control the work of street openings and the construction of the rapid transit subways. New York and St. Louis have each a board of public improvements composed of commissioners, each of whom has control over a subordinate division. In St. Louis the board consists of a president, the street commissioner, water commissioner, harbor and wharf commissioner, park commissioner, and sewers commissioner; and in New York of a president and six commissioners of bridges, highways, sewers, street cleaning, water supply, and public buildings, respectively. But separate boards control the construction of the new Croton aqueduct and the rapid transit tunnel. Philadelphia and Cleveland have each a single director of public works, with subordinate heads over the street and waterworks bureaus. 


\title{
CHAPTER XII
}

\section{Municipal Improvements. II}

\author{
WATER SUPPLY
}

Authorities. - John F. Fanning: A Treatise on Water Supply and Hydraulic Engineering, 1877.-E. Sherman Gould: The Elements of Water Supply Engineering, 1899. - William R. Billings: Some Details of Waterworks Construction, 1889.-M. N. BAKER : Manual of American Waterworks, 1897. - Willia P. Mason: Water Supply, considered principally from a Sanitary Standpoint. - JAMes W. HiLl: The Purification of Public Water Supplies, 1898. - Allen Hazen : The Filtration of Public Water Supplies, 1895. - George W. Fuller: A Report on the Purification of the Ohio River Water at Louisville.-George W. RAfter: The Microscopic Examination of Potable Water.-George C. Whipple : The Microscopy of Drinking Water. - Henry C. Merer: Water Waste Prevention.-A. P. Folwell: Water Supply Engineering.-James H. Fuertes: Water and Public Health. - Mansfield Merriam: Elements of Sanitary Engineering. - William Humber: Water Supply of Cities and Towns, 1876. - Municipal Affairs, 2 : 710. - Engineering Magazine, 17:937. - Edinburgh Review, 188:151.— Transactions of American Society of Civil Engineers, $6: 107 ; 34: 23$, $185 ; 38: 1,115 ; 43: 244$.

\section{Public Lighting}

C. W. BAKer : Monopolies and the People, pt. I, ch. 5. ; pt. II, ch. 4 ; pt. III, ch. 2. - E. W. Bemis : Municipal Monopolies.-A. R. Foote: Public Ownership. -J. H. GRAY, in Quarterly Journal of Economics, Vols. 12, 13, 14. - Reports of Massachusetts Gas and Electric Light Commissioners. Municipal Affairs, 4:520. - Penny Magazine, 3:373-492. - La Grande Encyclopédie, article Éclairage. - Annals of American Academy of Social and Political Science, $2: 715 ; 11: 1 ; 16: 318$. - American Economic Association Publications, 5:1; 6:287-471. - Journal of Franklin Institute, $31: 231$; $51: 289$; $53: 385$; $55: 207$; $57: 235$; $58: 35$; $63: 209$; 65:238 ; $70: 13 ; 100: 243 ; 101: 113,297 ; 102: 32-35 ; 105: 415$. - Chambers's Journal, 71:463. - V. Rosewater, in American Statistical Society Publications, 3 :293. - Political Science Quarterly, 10:87. - Reviewo of Reviews, $7: 61$. Engineering Magazine, 9 : 261 ; 14 : 780. 


\section{Street RaIlways}

Street Railway Journal, April 7, 1900. - Municipal Affairs, 3: 234. Report of Massachusetts Committee on Street Railways, 1898. - Cassier's Magazine, 15 : 241 ; 16 : 283-302 ; 357-370 ; 381-388; $17: 279-294$; Scientific American Supplement, 47 : 19349, 19595. - Quarterly Journal of Economics, 14 : 121. — Independent, 52 : 140. — Engineering Magazine, 16 : 1019 ; 20 : 173 191. - Engineering News, May 14, 1896. - Consular Reports, December, 1899. - Scientific American, $83: 260$.

\section{Docks aND HaRBors}

Scribner's Magazine, 26 : 385. - Transactions of American Society of Civil Engineers, 29: 128. - L. F. Vernon-Harcourt, Harbors and Docks. Consular Reports, January, 1898. - Engineering Record, 40 : 126, 150, 172, 198, 224. - H. C. Holmes, Report to California State Board of Harbor Commissioners.

\section{Markets and Abattoirs}

National Record, 21 : 285. Journal of Society of Arts, $43: 431$. Report of Parliamentary Commission on Markets. - Municipal Affairs, 2 : 716-742.

THE public improvements thus far considered are now recognized practically everywhere as undertakings in which the public interest and public benefit, convenience and health, warrant and demand public action; and the discussion on municipal activity along these lines has indicated in the main the extent to which these improvements have been established. We come now, however, to a series of undertakings in which private companies as well as municipalities are engaged, while both municipal and private undertakings are generally conducted so as to charge directly the individual benefited with a share in the expense. We shall find that these undertakings all have a public character. Not only does their equipment form an important part of the physical structure of the public streets, but their purposes and objects are in large part distinctly public. Nevertheless, the fact of payment according to the extent of their use shows that the individual benefits are both important and can be discriminated. These conflicting forces explain the existence of both public and private undertakings, the latter, however, always operating under a grant or franchise from public authority, while economic conditions 
bring it about that in cases of private undertakings one corporation, in most cases, eventually takes control of the entire service in one field for each locality.

In studying these fields of municipal administration, it therefore becomes necessary to note, in addition to strictly municipal undertakings, the existence also of private undertakings, and the conditions under which they operate.

\section{WATER WORKS}

As in the case of other extensive public works, there is a long gap between the undertakings in ancient times and those in modern cities. For instance, the mediæval cities depended on wells within the limits of the town, which were usually under the control of the municipality. We find some early attempts at municipal action on a slightly larger scale. In 1236 the London magistrates purchased the liberty to construct a water supply, and in 1283 built a conduit to bring the water to the city. ${ }^{1}$ In 1420 Southampton leased from a monastery its water supply; in 1585 Plymouth was authorized by Parliament to build municipal waterworks; and the Oxford public water supply dates from 1610. None of these instances, however, includes any extensive works.

Probably the earliest important water undertaking since the aqueducts of antiquity was that in the early years of the seventeenth century, by which the water of New River in Hertfordshire was brought to London, a distance of 40 miles. This project was devised by Hugh Middleton, who, when the city corporation failed to undertake it, began it himself and completed it in 1613 with the aid of James I. This was the beginning of the New River Company, the oldest of the existing water companies in London. In 1721 the Chelsea Company was founded, and with the New River Company and several smaller companies supplied London until the end of the eighteenth century. Then within a short period seven other London companies were formed to supply water to

1 Waterworks of Europe, III, p. 1; Gomme, Principles of Local Government, p. 101. 
various districts in the British metropolis : the Lambeth in 1785, the Grand Junction in 1798, the Vauxhall in 1805, the West Middlesex and East London in 1806, the Kent in 1810, and the Southwark in 1822. These derived their supply mainly from the upper Thames, the Lea, and from wells.

At Paris an aqueduct built in the Roman times was restored early in the seventeenth century; and other water supply works and pumping machinery were built both by the royal government and by the municipal authorities. In 1807 the two systems, which furnished a total supply of only 14 litres per head, were combined. A new gravity supply was secured by constructing the Canal d'Ourcq, which was further supplemented by wells; but during the first half of the century the supply remained inadequate and unsatisfactory. ${ }^{1}$ The other large cities of Europe, however, had much less important waterworks than either London or Paris.

The movement toward extensive waterworks and municipal undertakings began in the United States during the second third of the nineteenth century. A public water supply had been built at Boston as early as 1652, and other towns had public wells; but for the small communities of the colonial days no important works were necessary. By 1800 there were five cities in the United States with public waterworks; but even as late as 1835 Philadelphia was the only important city with a municipal supply. Within the next four years, however, St. Louis, Detroit, and Cincinnati established municipal works, and New York began the construction of the Croton reservoir and aqueduct, 40 miles in length, which, when completed in 1842, was the first large modern system of water supply. A few years later the Boston waterworks were under construction, and these examples were soon followed by Albany, Chicago, Cleveland, Worcester, Hartford, Baltimore, and other cities less important. About the same time the movement toward municipal waterworks became noticeable in Great Britain. Sheffield had taken over its supply in 1830, and Manchester in 1847. In the next decade Oldham and Glasgow, and in

1 Block, Administration de la ville de Paris, p. 459. 
later years Wolverhampton, Edinburgh, Lincoln, Birmingham, Liverpool, and ultimately most of the leading British cities, adopted the same policy. Of the works undertaken in British cities about the middle of the century, those of Glasgow were the most important. Loch Katrine, 34 miles distant, was selected as a new source of supply, and conduits having a capacity of 50,000,000 gallons a day were built to the city.

Paris, Berlin, and Moscow also began the construction of new water supplies about the same time (1854-1858). The Berlin system, begun in 1852, was constructed and operated by a private company. In Paris the works of the private company which had supplied the suburban districts were purchased by the municipality, and new works were installed, including an aqueduct from the sources of the Dhuis, 80 miles distant. A large scheme for bringing water from the sources of the Vannes, 107 miles away, was not completed until 1874, and in the twenty years ending at that time $\$ 20,000,000$ had been expended for waterworks in Paris.

Soon after 1870 large water supply systems were built for a number of other important cities on the continent of Europe. Frankfort-on-the-Main began a new system in 1870 which brought water from the Vogelsberge and the Spessart, 41 miles from the city, and in 1871 the system came into the hands of the municipality. In 1873 Alpine water was introduced in Vienna. The new Florence waterworks were begun in 1872 and completed in 1877. About the same time the authorities at Rome began the restoration of broken aqueducts, and by 1885 were able to prohibit the use of wells. By this time Munich and Naples had under construction new water systems, the latter bringing its supply from the mountains, 50 miles distant. Paris in 1886 began the provision for new sources of supply.

Of more recent undertakings, special mention may be made of the Liverpool supply from Lake Vyrnwy in Wales, 68 miles distant; the Birmingham works from the Elan River, 80 miles distant; the Manchester supply from Lake Thirlmere, distant 95 miles; and the works for the metro- 
politan district embracing Boston. New York has enlarged its storage reservoirs in the Croton valley and built a second larger aqueduct, but in the near future will probably undertake a still larger scheme of waterworks construction.

At the present time municipal water supplies are the general rule for the larger cities in all countries; but in the Latin countries the private supplies are comparatively much more numerous than in English-speaking and Germanic countries. England has still the tremendously important instance of London, also Bristol and five other towns of over 100,000 population - out of 29 towns in this class - where the water supply is not under municipal control. In the United States there are nine instances of private works in cities of over 100,000 population - San Francisco, New Orleans, New Haven, Paterson, St. Joseph, Omaha, Los Angeles, Memphis, and Scranton.

In cities with less than 100,000 population, waterworks owned by private companies are somewhat more frequent; but in the United States, Great Britain, and Germany, municipal plants predominate in cities having over 10,000 inhabitants. Of United States cities with 30,000 population and over in 1900, 94 have municipal works as against 35 with private works; and in cities of over 8000 population in 1890 there are 263 municipal to 190 private works. In Massachusetts and the states of the middle West municipal plants predominate even in the small towns. For the United States as a whole in 1898 there were 1787 municipal waterworks, as compared with 1539 waterworks under private control; but the total investment in municipal plants $(\$ 513,852,568)$ was nearly double that in private works. ${ }^{1}$

Out of 303 boroughs in England 268 have a municipal water supply, so that, with the exception of London, municipal works for cities of importance are more general than in the United States. In the smaller communities, however, municipal works are not so frequent. Only 280 of the 696 urban districts not boroughs have a municipal water supply. The total investment in municipal works in Great Britain is

1 Report of Commissioner of Labor, 1899, p. 12. 
$\$ 240,000,000 .^{1}$ In Germany only four of the 55 cities with over 50,000 population have not municipal waterworks. But of 1244 Prussian towns, 336 still rely on private wells and pumps. $^{2}$

In a number of important cases there are joint supplies of water for two or more municipalities. Manchester furnishes two-thirds of the water supply of Salford; Liverpool supplies Bootle; and there are other instances in England where joint boards for two or more municipalities control a common supply. In the United States the Metropolitan waterworks in Massachusetts supplies Boston, Chelsea, Everett, Malden, Medford, Melrose, Newton, Somerville, Belmont, Hyde Park, Revere, Winthrop, Watertown, Quincy, Nahant, Swampscott, and Arlington. ${ }^{3}$ A large private company furnishes water to towns on the Susquehanna River between Wilkesbarre and Scranton. In Melbourne and Sydney there are special boards which supply water to the various municipalities making up each of the urban districts.

In a very few instances water supplies are owned by the general government : as, for example, Copenhagen, Denmark, and Adelaide, Queensland.

Municipal waterworks have in every case two main divisions: the supply system and the distributing system. There are two classes of supply systems, the gravity and the pumping systems. The former involves the impounding of natural watercourses in an elevated valley, usually above sources of pollution, and the construction of a lengthy aqueduct from the storage reservoir to the city. The latter system may be necessary even when water is brought from a considerable distance; but more frequently the pumping system is used where the water supply comes from near-by sources. Storage reservoirs and aqueducts are in these cases not always required; but the pollution of waters near a large city makes necessary in such cases

1 Municipal Year Book, 1900, p. 406.

2 Engineering, 68 : 617.

8 Each of these municipalities maintains its own distributing system; and some have also a partial source of supply. 
the use of filtration plants. Such filtration works are most important in the case of cities located near the mouth of a large river which is used for the source of water supply. Thus the London water companies, which secure their water from rivers and wells, have used sand filters since the middle of the nineteenth century, although their action in removing bacteria from the water was not at first understood, and in consequence the best methods were not adopted until recently. The valley of the Elbe River contains a large number of great cities, most of which use the adjacent river water, polluted by the population in the upper part of the valley; and filtration works are to be found here for most of the large cities. The most important are those of Berlin and Hamburg, the latter, constructed after the cholera epidemic of 1892, being the latest and most improved system in the world. Other important filtration works are those at Rotterdam, The Hague, Amsterdam, and Zürich. The first Berlin filters were built in 1855 ; but the new filters, covering an area of 23.3 acres, are very recent. The London filters now have a total area of 110 acres. In the United States the principal sand filtration works are at Lowell (1876), Hudson (1874-1875), Poughkeepsie, Lawrence, Mass., and Providence. A large number of other cities have means of mechanical filtration - New Orleans is the largest, and Albany and Elmira may also be mentioned. ${ }^{1}$

The distribution system is a network of large mains and pipes throughout the city, connecting with outlets in the private houses and with public fountains and hydrants. The use of iron and steel for piping has been an important factor in extending the distribution system, not only of the public works, but also of the private pipes in the houses; and by this means the daily consumption of water has been greatly increased.

Statistics of the per capita consumption of water indicate the comparative extent of municipal activity in this field, and furnish the basis for interesting problems. The figures for German cities show that some cities there provide

${ }^{1}$ Hill, Purification of Water Supplies, p. 203. 
less than 15 gallons daily per capita, while in more than half of the cities of over 50,000 population the supply is between 15 and 25 gallons daily per capita. Bremen, Dresden, Leipzig, and even Berlin are in this class, the daily supply in the capital being 19.5 gallons per capita. Frankfort-on-the-Main (daily capacity 35 gallons per capita), Munich (46 gallons), and Hamburg (47 gallons) are among the best-supplied German cities ; and only in a few cities is the supply over 50 gallons per capita, such as Dortmund ( 55 gallons), Lübeck (59 gallons), Augsburg (60 gallons), and Freiburg (75 gallons).

In Paris the daily supply is 52.8 gallons per capita, and this is somewhat exceeded by the daily capacity of Rome; but it is doubtful if other French and Italian cities have more abundant supplies than the German cities. Zürich in Switzerland has a daily capacity of 88.6 gallons per capita, which is much the largest rate in any European city.

The British cities in general provide a larger supply than the cities on the Continent. Only in a few cases is the figure below 20 gallons, while in most cities it is above 30 gallons. Instances are rare, however, in which the per capita consumption is above 40 gallons per day, and that figure is the average of the London companies. Glasgow, with 60 gallons per head, is the most liberally supplied city in the United Kingdom.

In the United States 100 gallons per capita seems to be in general the minimum limit for the largest cities, and the supply rises in many cases well above this figure, and occasionally reaches as high as 200 gallons. Furthermore, the tendency is steadily toward an increase in the amount drawn. This larger consumption of water in the United States is due in part to conditions here which favor its more general use for beneficial ends : the distribution of water into almost every room promotes a larger use for domestic purposes; a larger amount is utilized in water-closets and bath-rooms, which are so much more general in this country than elsewhere; the amount used for public purposes, such as the extinction of fires and the flushing of sewers and streets, is 
also greater in the United States than in foreign countries. But even after considering these conditions, the amount of water drawn off is seen to be much more than enough to supply all proper demands; and there is clearly a large waste of water, through leaks in the mains and by the carelessness of householders in allowing water to run or in delaying to repair leaky faucets. The general use in all houses of water meters, such as are now used by large consumers of water, would serve to prevent waste in houses; and the experience of Fall River indicates that a large saving can be effected in this way. Leaks in the mains, which are probably the principal sources of waste, could be reduced by the examination of older pipes from time to time, and in the larger cities could be prevented to a great extent by placing the underground pipes of the congested streets in large subways, where they would constantly be open to inspection.

Public Aspects. - The existence of both municipal and private works suggests a study of the public and private aspects of water supply, which may indicate some explanation of the large extent of municipal works. The public aspects of a city water supply are of fundamental importance. An abundant supply for private consumption and for use in connection with modern drainage systems is a vital factor in promoting the public health, and is also an essential element in the work of fire brigades. Moreover, the distribution system requires the use of public thoroughfares, and the supply works in most cases call into play the governmental power of eminent domain to secure an adequate supply and a continuous right of way for the conduits from the sources of supply to the city. These considerations show that there is a large field of public interest in the administration of city waterworks. On the other hand, the use of water for household and industrial purposes belongs distinctly to the field of private interest. This is recognized by the charges made to the consumer for the use of water, ${ }^{1}$ whether fur-

1 Marseilles, France, has a water tax instead of water rates. 
nished by a municipal or private plant. Except in the small communities the income from private consumers usually pays the expenses of the waterworks, ${ }^{1}$ the water for public purposes being thus secured without cost to the general revenue.

Waterworks franchises are granted in most instances for a period of from twenty to thirty years, occasionally for fifty years, and in a few instances for ninety-nine years or in perpetuity. Nearly half of the franchises in the cities of the United States make some provision for future municipal purchase-some name a fixed interval at the end of which the city may purchase, and in other cases the property may be purchased at any time. A few franchises specify the purchase price, or state the basis of price; but in many instances the only provisions are that the value is to be determined by disinterested appraisers, and statements defining in general the method of appraisement. The franchise generally names certain rates to be charged to consumers, which in some cases are subject to modification at certain times; but occasionally there is no regulation of rates. Private companies often furnish water to the municipalities for public purposes free of charge.

\section{PUBLIC LIGHTING}

Municipal activity in the field of public lighting is closely connected with modern developments in the means of artificial light. Only in the case of two of the ancient cities (Antioch and Alexandria) is there any record of public lighting; and it is uncertain how far or in what way this function was undertaken even in these two cities. Throughout the Middle Ages there was a complete absence of municipal lighting; and it is not until 1524 that we find a decree of the Parlement requiring the householders of Paris to display lanterns, each containing a lighted candle. Similar enactments were thenceforth repeated at intervals; but no systematic or extensive public lighting was adopted, even

1 See Report of Commissioner of Labor, 1899, pp. 325-335. 
in Paris, before 1667, when the new lieutenant of police established a definite system of public lanterns. ${ }^{1}$

The example of Paris was followed by London in 1668, by Amsterdam in 1669, Berlin in 1679, Vienna in 1687, Leipzig in 1702, Dresden in 1705, Frankfort in 1707, Basel in 1721, and during the eighteenth century by most of the important cities in Europe. ${ }^{2}$ The Paris street-lighting system, as it existed in 1763, consisted of 6500 lanterns, each fastened to a cord hung across the street, and lighted for twenty nights a month from October to March. The lanterns were furnished by contractors, and the lighting was attended to by officials elected in each section of the city. ${ }^{3}$ About 1765, oil lanterns with reflectors began to be substituted for candles. This apparently was accompanied by a reduction in the number of lights, for in 1790 there were but 3783 lanterns, and the cost of public lighting in that year was 617,472 francs.4

\section{Gas Lighting}

But public lighting on an extended scale did not begin until the possibilities of illuminating gas had been demonstrated. Experiments in gas lighting were made in the years immediately preceding and following 1800 . Manchester had some gas street lights in 1802; and in 1807 the Gas Light and Coke Company laid pipes in Pall Mall, London, to light that street with gas. Six years later this same company - having now a franchise from Parliament-established lights on Westminster Bridge over the Thames; in the following year the streets of Westminster were lit by gas ; and by 1816 gas street lights were common in London. In the course of a few years the new illuminant had been adopted in all the principal towns in the kingdom for lighting streets and public buildings. But although these public lights were almost the only gas in use, the works, pipes, and lamps were established by private companies under con-

1 La Grande Encyclopédie, 15 : 535.

2 Meyer, Konversationslexikon, 16 : 506.

3 Mildmay, Police of Paris, 120, 121.

4 Block, Administration de Paris, p. 430. 
tract with the public authorities, except in Manchester, where the police commissioners in 1824 set in operation the first municipal gasworks. ${ }^{1}$

Gas lighting was by slow steps extended to other countries. It was introduced in Paris in 1815, but in 1821 there were still 12,000 oil lanterns in the Paris streets, and not until 1838 were these entirely removed. The first gasworks in Germany were at Hanover, in 1825, followed by similar works at Berlin in 1826, at Dresden and Frankfort in 1828, at Vienna in 1833, and at Leipzig in $1838 .^{2}$ Gas was introduced into Boston in 1823, and into New York two years later. By the middle of the century gas was to be found in most important cities throughout the world. The works in America, like those in Europe, were established by private companies, with which the municipalities made contracts for street lighting; but in 1845 Philadelphia established municipal gasworks, and in 1847 Berlin declined to renew the concession to the private company there, and put in operation municipal works.

Probably the first carefully drawn gas franchise was that granted by Paris in 1846. The six companies then in operation were given the exclusive right to lay pipes in the street, while the rates, both for public and private use, were specified in the agreement. In 1855 the companies consolidated, and a new agreement was made with the municipality for fifty years, and was adapted to include the suburban territory annexed in 1860, when the companies in these outlying districts were absorbed in the consolidated company. ${ }^{3}$

Since $\mathbf{1 8 5 0}$ the use of gas has increased enormously in the large cities, and has also been introduced in the smaller cities. During the last thirty years, many of the large British and German cities have followed the examples of Manchester and Berlin, and have established municipal gasworks, usually purchasing the existing local plant. Glasgow

\section{Encyclopadia Britannica.}

2 Meyer, Konversationslexikon, 11 : 284.

Block, Administration de Paris, p. 430. 
bought out the local gas supply in 1869, Leeds in 1870, Bradford in 1871, Birmingham in 1873. Thirty-two out of sixty-five towns with over 50,000 population in the United Kingdom now have municipal works. The principal exceptions are London, Liverpool, Sheffield, and Dublin. Including the smaller towns, there are 222 municipal gas plants, as compared with 439 private plants; and the investment and product of municipal plants in proportion to that of private plants is in the general ratio of one to two.

S'TATISTICS OF BRITISH GASWORKS, 1899

\begin{tabular}{|c|c|c|c|c|c|c|c|}
\hline - & \multicolumn{3}{|c|}{ Items } & & & Municipal Plants & Private Plants \\
\hline Number & . & • & • & • & • & 222 & 439 \\
\hline Capital & . & - & • & • & • & $28,614,971$ & $£ 53,494,781$ \\
\hline Receipt & . & - & • & • & • & $£ 7,177,670$ & $£ 14,093,125$ \\
\hline \multicolumn{2}{|c|}{ Expenditures } & . & • & • & - & $£ 5,365,995$ & $£ 10,309,948$ \\
\hline \multicolumn{2}{|c|}{ Miles of mains } & - & - & • & - & 10,030 & 15,451 \\
\hline \multicolumn{2}{|c|}{ Consumers. } & - & • & • & - & $1,578,291$ & $1,670,847$ \\
\hline
\end{tabular}

In Germany municipal gasworks are even more common; forty-one of fifty-four cities with over 50,000 population have municipal plants, the principal exceptions being Augsburg, Frankfort, and Hanover. Aggregate figures for all Germany for 1885 showed that of gasworks for public lighting there were 338 municipal plants, as against 329 private ones (although there were also 590 small private companies for purely trade or other special purposes). The gas production of the municipal works was double that of the private works. ${ }^{1}$

Municipal gasworks are also to be found in most of the large cities of Holland, Austria, Norway, Sweden, and Switzerland : in Amsterdam, Rotterdam, Prague, Trieste, and Stockholm. Occasional instances of municipal gasworks are to be found in other countries. Several of the smaller Italian cities have had municipal works for some time, among them Como, Vicenza, Spezia, and Azti; in 1896 Padua and in 1900 Bologna purchased the plants of the

1 Meyer, Konversationslexikon, 11 : 284 : - 279 municipal works, 325 mill ion cubic metres of gas ; 287 private works, 152 million cubic metres of gas. 
local private companies. Isolated instances of some importance are Brussels, the City of Mexico, and Yokohama. In France there are said to be 28 smaller towns with municipal works, and in New South Wales 17 small towns. In the United States there are only 14 cities with municipal gasworks, as compared with 951 private plants, while most of the municipal works are in small towns. Since Philadelphia has leased its municipal plant to a private company, the principal cities operating municipal gasworks are Toledo (a natural gas supply for fuel purposes), Richmond, Duluth, and Wheeling. The total investment in municipal gasworks in the United States for 1898 was $\$ 1,918,120$, as against $\$ 330,346,274$ invested in private works; the value of product in the municipal works aggregated $\$ 487,355$, and in the private works $\$ 73,446,133$. $^{1}$

The existence of a large number of both municipal and private gasworks in Great Britain renders a comparison between the two systems in that country of some value. Such a comparison shows distinct advantages enjoyed by the municipal plants in that country. The financial results show that the prices charged by the municipal plants are about 10 per cent less than those charged by private works, while the quality of gas furnished grades about 14 per cent higher for the municipal works. At the same time the profits after making adequate charges for depreciation and sinking funds are nearly as large as those for private works. The full significance of these figures is, however, indicated in the much larger consumption of gas from municipal works. While in number of plants, capitalization, and product, the ratio of private to municipal works is about two to one, yet the number of consumers of gas in each class is practically equal. Thus in 62 cities with over 50,000 population, the statistics show :-

\begin{tabular}{l|c|c|c}
\hline & Population & Consumers & Ratio \\
\cline { 2 - 4 } 31 Municipal Works & $5,528,833$ & $1,115,410$ & $\begin{array}{r}4.9-1 \\
9.3-1\end{array}$ \\
31 Private Works & $4,752,793$ & 507,169 & \\
\hline
\end{tabular}

1 Report of Commissioner of Labor, 1899, p. 12. 
The more general use of gas by the poorer classes indicated by these figures means a great improvement in the sanitary and social life of that part of the city population, which cannot be measured statistically.

\section{Electric Lighting}

The possibility of electric lighting was demonstrated in Paris in 1877; but the practical use of such lighting dates from 1880, when an arc electric plant was installed at Wabash, Ind. Another Indiana town (Vincennes) claims the honor of the first incandescent electric lighting plant, erected in 1886. Both arc and incandescent systems were rapidly extended to other cities in the United States, the incandescent lamps being used mainly for indoor lighting, and the arc lights for street lighting. The precedent of private ownership of lighting plants which prevailed in the United States was followed in most places in regard to the new electric works. But as early as 1882 a municipal electric light plant was established in the small city of Fairfield, Ia.; a few other cities established similar plants within the next few years, among which may be named Decatur, IIl. (1886), Chicago (1887), and a large number of others established since 1890.

In 1898 there were all together in the United States 468 municipal electric light plants as compared with 2578 private plants. But most of the municipal electric works are in small towns, whereas private plants furnish the supply in nearly all the large cities, and consequently represent a much larger proportion of the total investment in electric lighting. In many cases, too, the municipal plant furnishes only public lighting, and leaves the demand for private consumption of electric power to be supplied by private companies. The total municipal investment is $\$ 12,902,677$, and the investment of the private companies $\$ 265,181,920.1$ The principal cities with municipal plants are Chicago, Detroit (1895), Allegheny (1890), and Grand Rapids (1899). Michigan, Ohio, and Illinois have the largest number of

1 Report of Commissioner of Labor, 1899. 
municipal plants, with Minnesota, Iowa, Missouri, Indiana, and Pennsylvania following, in the order named. In point of importance of municipal electric light works, Illinois ranks first, Michigan second, Ohio third, Pennsylvania fourth, and Indiana fifth. There are but few municipal plants west of Iowa or south of the Ohio River or Pennsylvania.

STATISTICS OF MUNICIPAL ELECTRIC LIGHT PLANTS, 18971

\begin{tabular}{|c|c|c|c|c|c|c|c|c|}
\hline \multicolumn{4}{|c|}{ States } & \multirow{2}{*}{$\begin{array}{c}\begin{array}{c}\text { Number } \\
\text { of } \\
\text { Plants }\end{array} \\
36\end{array}$} & \multirow{2}{*}{$\begin{array}{c}\begin{array}{c}\text { Number } \\
\text { Arc } \\
\text { Lights }\end{array} \\
5,158\end{array}$} & \multirow{2}{*}{$\frac{\begin{array}{c}\text { Number In- } \\
\text { candescent } \\
\text { Lights }\end{array}}{22,564}$} & \multirow{2}{*}{$\begin{array}{c}\begin{array}{l}\text { Horse } \\
\text { Power }\end{array} \\
7,810\end{array}$} & \multirow{2}{*}{ Capital } \\
\hline Illinois & . & . & . & & & & & \\
\hline Michigan & . & . & . . . & 42 & 3,964 & 48,786 & 7,178 & \\
\hline Ohio . & . . & . & . . & 42 & 2,821 & 40,480 & 7,376 & \\
\hline Pennsylv & ania & . & . & 17 & 2,025 & 16,915 & 4,223 & \\
\hline Indiana & & . & - & 19 & 1,403 & 18,150 & 3,910 & \\
\hline Massachy & usetts & - & . . & 15 & 1,271 & 38,243 & 3,865 & \\
\hline United S & tates & - & • & 353 & 25,343 & 354,031 & 59,500 & \\
\hline Private $C$ & Compa & anie & s, U. S. & 2,261 & 264,428 & $7,234,134$ & $\mathbf{9 7 0}, \mathbf{4 8 1}$ & $\$ 229,938,605$ \\
\hline
\end{tabular}

An act of the British Parliament in 1882 authorized municipal and private electricity plants under the supervision of the Board of Trade. Private plants were established at Eastbourne and Hastings in 1882, at London in 1885 , and three others in 1887-1888. But the restrictions on private companies, and failures in the early cases, prevented rapid development; while municipalities, although securing licenses to keep out private companies, did not venture to establish works of their own. A new act of 1888 granted more favorable terms for private companies, although still providing for municipal purchase. New companies were organized, and beginning with Bradford in 1889, and Brighton and St. Pancras (London) in 1891, the municipalities also began to enter actively into this field. At the end of 1900 there were 198 works in operation - 130 under municipal management, and 68 in private hands. There were 121 new works under way, 99 by public bodies, and

1 Bemis, Municipal Monopolies, p. 202. 
22 by companies. In the larger cities municipal plants are almost universal. Both towns with municipal gasworks and those where the gas supply is delivered by private parties have entered this new field. Even in London several of the districts have municipal plants, although private companies control much the larger share of the metropolitan supply of electricity. Outside of London the only cities with over 100,000 population which do not have municipal works are Newcastle, Norwich, and Preston.

On the continent of Europe most public electric light plants in Teutonic countries are municipal. In Germany, however, there are a number of important exceptions to this rule. In Berlin and Leipzig, where the gasworks are municipal, and also in Hamburg and other cities, electric lighting is in the hands of private companies. Frankforton-the-Main, Chemnitz, Plauen, and Aix-la-Chapelle have constructed municipal electric works, but have leased them for operation to private companies. Municipal electric light works are operated by the city governments in Munich, Breslau, Cologne, Dresden, Hanover, and most of the other important cities. There are also municipal electric works at Brussels, Rotterdam, Stockholm, Bergen, and Christiania ; and at Copenhagen there is a government plant. So too in Geneva, Berne, and many small places in Switzerland, there are municipal electric plants. In France, Italy, and Belgium municipal electric light plants are almost unknown, while in at least two cities, Brest and Ghent, the franchises of the gas companies have delayed the introduction of electric light.

Public Aspects. - As in the case of waterworks, the existence of both municipal and private lighting plants suggests an examination of the public and private aspects of lighting works, in which we may look for facts to explain (not necessarily to justify) the smaller extent of municipal works in the case of lighting plants, and the larger proportion of municipal plants in the case of electricity, as compared with gas lighting. 
Both gas and electric light works, like waterworks, make use of the public streets, and for gas plants, and also for electric light plants in large cities, this use involves the digging up of the street surface to lay and repair pipes and the repair of the street pavements. The overhead conductors of electricity in other than the largest cities do not involve so great a disturbance of the streets as the underground gas and water conduits. The lighting of streets and public places is of course a distinctively public work, undertaken not merely for convenience, but as a direct aid in the important and fundamental task of the police of the city. In these respects lighting works are on the same general basis as waterworks. But in other respects we find some differences. It seems probable that public lighting is a smaller share of the total lighting than public water consumption is of the total consumption; and what is of more importance, private lighting does not possess the same vital public interest that the private water supply has as a sanitary measure. Nor is it necessary in the case of lighting supply plants to make use of the power of eminent domain to condemn private property. The operation of gasworks involves more complicated industrial operations than either waterworks or electric light plants, including the purchase of raw materials, the employment of many skilled workmen, and the use of technical manufacturing processes constantly subject to improvement. Add to these conditions the fact that gas and electric lighting when first introduced were not considered at all as necessaries, but an alternative form of light to the old means, which might or might not be adopted by private consumers, and the further fact that for a time both in gas and electricity the complete success of the new methods was problematical, and the explanation for a smaller degree of municipal activity seems to be ample.

On the other hand, recent developments have changed the two conditions last named. The use of either gas or electricity is now almost, if not quite, a necessity in the large cities, and the definitive success of the new methods brings 
them more easily within the scope of municipal action, while the clear and inevitable tendency of lighting works in each city to consolidate into a single company possessing a practical, and often also a legal, monopoly adds to the demand for public administration or public control of private works.

Franchise Terms. - Most of the various terms and conditions mentioned in connection with waterworks franchises are found to some extent in franchises for public lighting: a limited term, right of purchase, rates for public and private use. But lighting franchises as a rule allow greater freedom to the private companies than do water franchises. An investigation by the American Economic Association in 1889 discovered 75 lighting franchises with no control of rates, while in only 14 water franchises was this the case. And only 23 out of 138 lighting franchises reserved to the city the right of purchase, while nearly half of the water franchises had such a provision. ${ }^{1}$ In the case of electric light franchises, conditions are generally more favorable to the company than in the case of gas franchises. One of the most stringent electric light franchises is that of Paris. The franchise granted in 1887 is for only fifteen years; it gives the municipality the right to lower prices every five years, and the right of purchase at the end of ten years, and the company pays to the city 5 per cent of its gross receipts. The lease of the Philadelphia municipal gas plant to a private operating company (in 1899) contains some important features. The company received the city plant subject to no direct payment to the city; but agreed to light the city streets free of charge, to spend $\$ 15,000,000$ on improvements, and at the end of thirty years to surrender the plant to the city. The lease also fixes the maximum prices for gas which can be received by the company at from 90 to 75 cents per thousand feet, but the city may place the price to the consumer as high as $\$ 1.00$, the difference to go to the municipal treasury.

1 American Économic Association Publications, II. 


\section{Massachusetts Gas and Electric Lighting Commission}

The highest development of public control over private lighting corporations in the United States is that exercised in Massachusetts by the State Gas and Electric Lighting Commission. This Commission was established in 1885 to supervise gas companies; and two years later its powers were extended to include electric light companies. It consists of three members appointed by the governor and executive council for three years, one member retiring each year. The members receive a salary, and are not permitted to engage in any other business. They can be removed only for cause, after notice and a hearing.

This Commission has control over the establishment and consolidation of companies, their rates, capitalization, and accounts. It has power on appeal to prevent municipalities from granting franchises to more than one gas or electric light company; and its policy has been to recognize the lighting business as a monopoly, and only in very exceptional cases to permit a duplication of plants. It has also favored the consolidation of gas companies and electric light companies in smaller cities and towns, but refused to permit it in the large city of Worcester. On complaint and investigation the Commission may order the prices charged for gas or electric light reduced or the quality improved. In these investigations the Commission does not act simply as a court, bound by legal rules of evidence and procedure; but proceeds on its own initiative, and applies all its knowledge concerning, not only the case in hand, but the business of every company in the State. Almost every petition for a reduction in prices has been acted upon favorably by the Commission, and the reductions have usually reduced dividends. Some companies also have made voluntary reductions in prices. In order to prevent over-capitalization and stockwatering, gas and electric light companies are required to secure the approval of the Commission for each new issue of stock or bonds. Finally, by securing uniform and public accounts and statistics from both public and private works, 
the Commission not only is able to act wisely in the exercise of its powers of control, but also can recommend additional legislation when necessary, and promote the intelligent public discussion of all lighting matters.

In New York State the legislature in 1886 passed an act fixing the maximum price of gas in New York city at $\$ 1.25$ per thousand feet; and in $\mathbf{1 8 9 6}$ provided for a slight annual reduction for a period of years. This action, taken without detailed study and a knowledge of business conditions and management, and entirely ignoring the probability of important changes in methods of lighting, cannot produce the successful results achieved by the Massachusetts system.

Many cities conduct a fire alarm and police telegraph system in connection with the fire and police brigades; but aside from these, other electrical services are seldom in the control of municipal authorities. The general telephone and telegraph business is in the hands either of private companies or of the general government. The general government has charge in Germany, France, Switzerland, Belgium and Holland, Japan, and Australian countries. Examples of municipal telephone systems are, however, to be found in Amsterdam and in Glasgow, the plant at the latter place being installed in 1901.

Franchises for telephones, telegraphs, steam conduits, pneumatic pipes, and the like, in United States cities are generally granted with almost no restrictions.

\section{URBAN TRANSPORTATION}

The development of systems of urban passenger transportation is far from the least significant feature of municipal development during the last half of the nineteenth century. Before the eighteenth century passenger movement on the streets was almost limited to foot traffic, the wealthy using sedan chairs carried by porters on foot. Horse vehicles were used only for long distance journeys. Gradually the use of carriages was extended, at first for private use, and later for public hire on a small scale. An 
attempt had been made as early as 1662 to establish a system of public carriages in Paris, but it had failed; and it was not until 1828 that an omnibus line was put in operation in that city. In 1829 omnibuses were put in operation in London, and additional lines were soon established both in London and in Paris, as well as in the other large cities of Europe. In general each line was established by a different company; and there were no important regulations or grants of privileges. In 1854, however, the fifteen omnibus lines in Paris were consolidated, and the combined company received an exclusive franchise for thirty years (the limit being afterward extended to 1910), on condition of large annual payments to the city. A year later the cab proprietors of Paris were likewise consolidated into a single company which received special privileges, and in 1862 it obtained an exclusive franchise on a similar arrangement to that with the omnibus company.

\section{Street Railways}

The first railway for urban street traffic was constructed and put in operation at New York in 1852.1 This was quickly followed by other lines in the same city, and by similar railways in other American cities: Boston (1853), Baltimore (1860), Detroit (1862), Albany (1863), Indianapolis (1864); and by 1870 there were lines in all the large cities of the United States.

All of these lines were constructed by private corporations, and in each of the larger cities there were several companies. The first franchises in New York were granted with no limit of time, although a five-cent fare was required, and the companies were to pave the streets between the rails and for some distance on either side. In Massachusetts also perpetual franchises were granted, which were, however, at the same time legally revocable by the municipalities at any time. In other cases the street railways were given rights in perpetuity or practically so (for example, at Albany a 
franchise was given for one thousand years); while the remainder of the early American franchises were for long periods, usually from fifty to one hundred years. There were few or no other restrictions on the companies, the only general requirement being that the company was to pave the street surface between their tracks. Not only were the first grants made without careful consideration or attention to detail, but the arrangements for extensions and new lines were made from year to year in the same manner, with no general plan, and hardly two grants had like conditions. The franchises granted by Baltimore, however, constitute striking exceptions to the general rule of carelessness and negligence in framing franchises. Mayor Swann of that city secured an agreement in 1859 providing for the payment to the city of 20 per cent of the gross receipts and for a license tax of $\$ 20$ per car, stipulating a five-cent fare and free transfers to any part of the city, and also reserving to the city the right to purchase the equipment at intervals of fifteen years.

In Europe street railway construction did not develop for nearly two decades after the new system of urban transportation was well under way in the United States. A short line was built at Paris in 1853; in 1865 a line from Berlin to Charlottenberg was opened; in 1860 a road was put in operation at Birkenhead; and in 1868 roads were established in Vienna, London, and Liverpool. But it was not until after the passage of the Tramways Act in 1870 that street railway construction became at all general in English towns, and on the Continent very little was done in this direction until after 1870. Roads were established in Glasgow in 1871, in Birmingham in 1873, in Berlin and Paris in 1873, and in Amsterdam in 1876. In Glasgow, Sheffield, and a few other towns of Great Britain the construction of the roadbed for their street railways was undertaken by the municipality, and the tracks were afterward leased to an operating company. Elsewhere both construction and operation were intrusted to private hands; but in all European cities there was a definite and carefully drawn contract be- 
tween the city and the company. In Great Britain the term was twenty-one years, and on the Continent most of the early contracts were limited to twenty-five years or less; while in all European countries both general legislation and the special contracts with the cities carefully regulated the relations of the company with the municipality and to the community.

The development of street railways in the United States had continued, not only by the extension of lines in the large cities, but also by the establishment of new roads in many smaller cities. Term franchises became somewhat more frequent, although the period was still fifty years or more, while in other respects the private companies remained subject to little control. Even in Baltimore the conditions of the original franchise were altered in favor of the company. In 1870 the elevated railroad was constructed in New York with no limit on its occupation of the streets; and although on the first road (that on Ninth Avenue north to Fifty-ninth Street) a payment of 5 per cent of gross receipts to the city was required, the other lines and extensions were exempt from all payments.

In the largest cities, the development of street railway facilities had often been secured by grants to new companies, and it was perhaps felt that the competition between rival lines was a better safeguard to public interests than intricate and rigid conditions in the franchise. In Philadelphia street railway franchises have been granted to thirtynine different companies, and as late as 1880 there were as many as seventeen operating companies. Soon after that date there began a process of rapid consolidation of all of the lines, in most cases into a single operating company for each city, such as the Union Traction Company of Philadelphia, the West End Railway (now the Boston Elevated Railway Company), and the Metropolitan Street Railway Company of New York. Contemporaneous with the process of consolidation went the application of new methods of traction. In the early eighties, cable roads were built in several large cities, where the large traffic warranted the heavy cost of construction. An experimental electric road 
was successfully constructed at Berlin in 1879, and other roads were built at Lichtenfeld (Germany) in 1881, and at Port Rush (Ireland) in 1883, the third-rail system being used. An electric road established at Cleveland (Ohio), in 1884, used for the first time an underground slotted conduit. None of these methods, however, offered opportunities for a general change in the methods of passenger transportation. In 1885 the first overhead trolley line was put in operation at Kansas City, and after a few years more of experimental lines, the trolley system began to be adopted on a large scale in 1888. Among the cities where this system was first introduced are Toronto (1885), Richmond (1887), and Allegheny. ${ }^{1}$ In Washington overhead wires were not allowed, and there the conduit system was first used on an extensive scale.

After 1890 the transition from horse to electric power was rapidly made in almost every American city. The rapid transportation afforded by the new motive power led to an astonishing development of traffic; and this, in turn, aided by the cheaper operating cost, has resulted in new extensions, construction in small towns, and even the establishment of inter-urban electric lines. The objection to the overhead wires and the persistence of small companies delayed the transition to electric power in Manhattan Borough of New York city; but the financial strength that has come through consolidation has made possible the recent construction of underground conduits for the principal lines in the American metropolis.

The formation of the consolidated traction companies, the extensions of the street railway systems, the change in motive power, and, to some degree, the expiration of former franchises, have in combination led to new agreements in recent years between the companies and municipal authorities in many American cities. These new agreements, in nearly every case, impose stricter conditions on the companies than the early franchises. The new charters are ordinarily for a limited term, rarely more than twenty-five

1 Cassier's Magazine, 16 : 361. 
years ; but Buffalo, in 1890, granted a franchise for 999 years, while in Pennsylvania and Massachusetts revocable perpetual grants are still made. There are, however, few exceptions to the rule that in these new agreements there is a provision for some payment to the city. The most frequent provision in this regard is for a fixed proportion of the gross receipts. In Cincinnati, Providence, and Richmond, this rate is 5 per cent. Various systems of car licenses and taxes on dividends and franchise values are also used in different cities. The provision for paving the streets between the tracks is also found in nearly every case. In Philadelphia this is extended to include the pavement of the entire surface of the street in which the tracks are laid, and about $\$ 12,000,000$ has been expended by the traction company during recent years for paving Philadelphia streets.

European cities continue to be far behind those of the United States, not only in street railway mileage, but to a still greater extent in the amount of traffic. The first overhead trolley line was established at Leeds in 1891; but the change to electric traction was hardly noticeable before 1894, and there are still important cities where the electric system has not yet been introduced. The German cities are the most advanced, their mileage of electric roads being equal to that of all other European countries combined. In 1900, electric roads were in operation in 99 German cities, and the total mileage was 1793 miles, ${ }^{1}$ as compared with 15,000 miles in the United States. The mileage of the electric roads in Great Britain in 1899 was only 210 miles.

In Italy the first electric tramway was built in 1890, and ran between Florence and Fiesole. A line was established at Genoa in 1892, and one at Milan in 1893 ; but these were of minor importance. Milan, in 1894, installed the first general system in Italy; and this was followed by similar works at Genoa and Rome in 1895. In 1898 electric rail-

1 Electrotechnische Zeitschrift, September, 1898; Statistisches Jahrbuch Deutscher Städte, VII, 145 ; Consular Reports, 1901, p. 378. 
roads appeared at Turin, Florence, and Naples ; and in 1899, at Leghorn. Other Italian cities where electric tramways are now operated are Palermo, Nervi, Perugia, Como, Catania, Spezia, and Brescia. On December 31, 1899, there were 153.6 miles of electric road in Italy, and 600 miles of urban and inter-urban road in process of transformation. In 1900 arrangements were made to extend the tramway at Nice for 93 miles through the Riviera. New lines are now under construction at Trieste and Fiume. ${ }^{1}$

The new contracts in all European cities, due to changes in motive power and expiration of former agreements, are very carefully drawn. These contracts, always for a fixed term, are especially detailed in the case of the German cities, where they not only define the legal relations of the roads and municipalities, but also prescribe the detailed regulations for the management of the road. They specify, for example, the number of trips, the rates of fare, the hours of labor, the dimensions of cars, and even the uniforms to be worn by the employees. Still further, they require the redemption of the capital, specify the details of repairing and maintenance, require specific extensions of the system, and provide, at the expiration of the contract, either for the free transfer to the municipality of the equipment of the road, or name the conditions on which the municipality may buy the plant.2

In Great Britain, and in a few cities in other countries, there has developed within recent years a movement toward municipal ownership and operation of the street railway systems. It will be remembered that under the British Tramways Act of $\mathbf{1 8 7 0}$ a few towns constructed the tracks for the local tramways, leasing them after completion to an operating company. This municipal ownership of the tracks has been extended by the construction of new lines in these and other towns, by the expiration of early franchises providing that the tracks should revert to the city as public property at the expiration of a term of years, and occasion-

1 Engineering Magazine, November, 1900.

Appendix to Report of Massachusetts Street Railway Committee, p. 74. 
ally by purchase; so that a large part of the street railways in the United Kingdom are now owned by the municipalities. In 1899 there were 519 miles of municipal railways, and 602 miles of private roads. Only five of the twenty-eight great cities in the United Kingdom - namely, Bristol, Leicester, Cardiff, Dublin, and Belfast - do not own some lines of street railway. The cities of Toronto (Canada), Frankforton-the-Main, Liège, and Milan, and probably some other cities, own the local railways and lease them to operating companies. The street railways of Melbourne, Australia, and suburbs, are owned by a joint board or trust representing the municipalities through which they run, but they are operated by a private company. In the United States underground railways or subways have been built in Boston, and are being built in New York, by the municipal authorities. In the case of Milan, the municipality receives the entire income, and pays the operating company a fixed rate for every car-kilometre travelled, and a certain proportion of the profits. In other cases the company pays the city for the use of the tracks.

While municipal ownership of street railways has thus existed in Great Britain since 1870, municipal operation was positively forbidden in the Tramways Act of 1870, and is only of recent development. The first exception was in 1882, when the corporation of Huddersfield was authorized to operate the local steam tramways, which had been abandoned by the operating company, provided no reasonable offer could be secured from another operating company to lease the lines; and with some hesitation the experiment was begun. The next instance of municipal operation occurred, not in Great Britain, but in the United States. When the Brooklyn Bridge over the East River was opened, in 1883, the cable road over it, one mile in length, was from the start operated by the trustees or joint committee representing the two municipalities of New York and Brooklyn. It continued to be operated by the bridge trustees until January 1, 1898, and after that by the Department of Bridges in the enlarged New York until July, 1898, when arrangements were made to 
operate it in connection with the Brooklyn elevated railroads by the company owning the latter roads.

The Huddersfield and Brooklyn Bridge railways remained isolated examples, and did not mark the beginning of any movement toward municipal operation. It was not until 1893 that other examples appeared. In that year two British cities (Plymouth and Blackpool) received authority to operate their tramways. The year following Leeds and Glasgow also began municipal operation. All of these instances were in the face of the Tramways Act of 1870; and a standing order of the House of Commons was now adopted shutting out any further bills authorizing municipal operation. In 1896, however, this order was repealed; Sheffield, Dover, Nottingham, and Hull thereupon received the necessary authority, and since then the movement in Great Britain has extended. Already twenty cities are operating the local railroads, the most important of which are Glasgow, the London County Council (which now owns 23 miles out of 111, and is taking over other lines as the franchises expire), Liverpool, and Leeds. Half a dozen other towns are now making the transition, while still others, such as Birmingham and Manchester, have applied for authority and have declared their intention to work their lines on the expiration of the present leases. Barmen in Germany and Prague in Bohemia, and a few Swiss towns, also operate local street railroads; but there is no such general movement in other countries as in Great Britain.

Public Aspects. - It is evident that street railways are to a much less degree under municipal management than either water or lighting works. In explanation we may note that what has been said as to the smaller importance of the public aspects of lighting as compared with water supply holds true in the case of local passenger traffic. There is not the need for resorting to the powers of eminent domain, nor is the problem of transit facilities so closely related to the public health as is the water supply. At the same time the operation of a street railway system requires a much more intricate 
and involved machinery of employees and of technical skill than does the maintenance of streets or a water supply system. On the other hand, it is true that the street railway, especially in its latest form, involves a more constant disturbance of the street surface than the underground conduits for water or gas. This suggests the advantages of municipal ownership of the tracks, which has been advocated by some as the best solution of the problem. This is perhaps a stage that will come into use in the United States, and it has already been favored by the special Massachusetts Committee of 1898, as avoiding the difficulty of municipal operation of roads running through several cities. It seems doubtful, however, that it will prove a final solution; the probability is that wherever adopted it will lead in time (as in Great Britain) to municipal operation.

The movement toward municipal street railways in Great Britain has been favored by special conditions. One important factor has been the decision of the $\operatorname{courts}^{1}$ that where a municipality purchases an existing street railway, the purchase price is not to include anything for franchise value or the good will of the company, based on present or past profits, but is to be simply the value of the tangible property in place. Where a term franchise has yet a period to run, or where a company has a grant in perpetuity, municipal purchase would necessarily include payment for the value of the franchise. In Great Britain, however, the expiration during recent years of former agreements has favored municipal ownership. At the same time, with the approach of the date of expiration, the private companies have not felt warranted in undertaking extensive improvements, such as the introduction of electric traction, while the municipalities already owning electric light plants have been more ready to introduce the new system. It is not clear, however, that if the municipal authorities had been willing to make new contracts extending the period of private operation, the companies would not have been as ready to make the improvements as they have been on the Continent.

1 Law Reports, 1894 A.C., 456, 489. 


\section{Ferries}

Water transportation is a much older means of locomotion than street railways; and in former times the ferry privilege for any city near a river was usually possessed by the municipality. With the development of bridge construction, however, ferries over small streams have been abandoned; and it is only where a large river must be crossed by considerable traffic that there are now important ferries.

In most countries the cities lease their ferry franchises to operating companies. The most important case is New York city, where the various ferry lines across the East and Hudson rivers pay to the city about $\$ 350,000$ a year. Other instances of ferry franchises are St. Louis, New Orleans, Toulon, Venice, Amsterdam, Rotterdam, Breslau, Prague, and St. Petersburg.

In Great Britain there are some important instances of municipal operation of ferries and local river steamers. The largest strictly municipal ferry is that across the Mersey from Birkenhead to Liverpool, owned and operated by the Birkenhead corporation. This employs eight steamers, and carries 7,000,000 passengers a year, besides freight and vehicles. The total receipts for the year ended March 31, 1899, were $£ 50,000$; the operating expenses for the same period aggregated $£ 21,000$; and after making charges for contingencies and depreciation, $£ 11,000$ were handed over in aid of rates. The Trustees of the Clyde River Navigation a public body dominated by the representatives of the Glasgow corporation - operate not only twelve ferries across the Clyde, but also ten small steamers plying along the river, carrying all together 15,000,000 passengers annually. The gross revenue is $\$ 160,000$ and the expenses $\$ 130,000$ a year. The Belfast ferries are also operated by the harbor commissioners for that port; the London County Council runs a free ferrry across the Thames at Woolwich, with a traffic of 4,000,000 passengers a year ; and there are further instances of municipal operation on a small scale in other British towns. 
Outside of Great Britain, the only important examples of municipal ferries are at Riga in Russia and at Boston, Mass. The former yield a gross revenue of $\$ 52,000$ a year. The latter are operated at a loss; but they have under all systems of management been financial failures. From the first establishment in 1833 to 1870 the Boston ferries were operated by private companies, at times with competing companies, and at other times with a monopoly; but only in two years (1853 and 1854) did any ferry company declare a dividend, and even subsidies from the municipal government proved of no permanent value. Since 1870 the ferries have been operated by the city, and by 1878 the receipts from tolls equalled current expenditures. But in 1887 tolls were cut in half, foot passengers being carried for one cent; and there has been a constant agitation for free transportation. The city has spent two and a half million dollars more than the receipts from all sources, and there is now an annual deficit of $\$ 100,000$.

\section{DOCKS AND HARBORS}

In many of the large commercial cities the dock and harbor facilities are under the control either of the municipality or of public boards on which the municipalities are represented. Such works were an important function of the ancient and mediæval commercial cities, and also of the seaport cities of Europe in the early centuries of the modern era. With the development of navigation and harbor facilities during the nineteenth century, however, the works of this period are much the more important, although, as they often represent private and not public activity, the whole field cannot be covered here.

At present most of the large harbor works in Great Britain are under the control of special harbor trusts, composed of representatives from the municipalities and from the local commercial interests. The great docks of London are, however, owned by joint stock companies. Probably the most important board where the municipal element is still dominant is the Trustees of the Clyde River Navi- 
gation, which have carried out the deepening of the Clyde from Glasgow to the mouth of the river, and constructed the docks and warehouses of the port. As early as 1556 the corporation of Glasgow undertook to deepen the shallow river, but little was accomplished, and the Clyde for twenty miles below Glasgow remained navigable only for herring boats and like craft. In 1662 the corporation began the construction of a harbor at Port Glasgow. In 1768 the task of deepening the river to 6 feet was begun, and carried through under the direction of the corporation in 1775. In 1809 the members of the Glasgow corporation were formed into the Trustees of the Clyde River Navigation, with authority to deepen the river to at least 9 feet. The work of dredging went on accordingly, and by 1818 vessels in the foreign trade were for the first time able to come up to Glasgow. In 1825 plans for a 13-foot channel were adopted, and fifteen years later it was decided to increase the depth to 17 feet. Along with the deepening of the channel went the work of building quays along the river.

In 1858 the constitution of the harbor trust was materially altered. According to the new form, which is still in force, the municipal corporation was represented by the Lord Provost and nine councillors, while fifteen. additional members were authorized from the shipping, mercantile, and trading interests of Glasgow. Under this management the harbor and docks have been steadily improved. There is now 27 to 29 feet of water in the river to Glasgow at high tide, so that all but the largest vessels can come up to the city, while the largest ship-building yards in the world are situated on the Clyde, just below Glasgow. Since 1865 three large enclosed tidal docks have been constructed, with a water area of 160.5 acres, and a total wharfage of 6.25 miles, and 30 acres of sheds. The wharves are well equipped with all the machinery for the rapid loading and unloading of vessels, and the equipment includes nine miles of railway tracks, connected with the railway system of Great Britain. The total cost of the Clyde improvement works to 1897 was $\$ 70,000,000$, and the gross revenue was $\$ 50,000,000$. The annual revenue is 
now $\$ 2,000,000$, of which there is left, after paying expenses and fixed charges, a surplus of $\$ 200,000$ annually.

The first dock at Liverpool was constructed in 1709; and during the eighteenth century the municipal corporation expended $\$ 1,200,000$ on docks and harbor works. The later and more extensive works have been carried on by the Mersey Docks and Harbor Board, which consists of twenty-four members elected by the ship-owners or dock rate-payers, and four members representing the county boroughs of Liverpool, Birkenhead, and Bolton. The docks have a total area of 1000 acres, with a wharf frontage of 27 miles. The total expenditure has been $\$ 200,000,000$, half of which has been spent since 1857. Receipts are about $\$ 5,000,000$ a year.

With this group of harbor works may also be classed the Manchester ship canal, which provides not only a channel from the Mersey to Manchester, but also the harbor facilities at Manchester. That municipality has invested $\$ 25,000,000$ in the bonds of the ship canal company, and that sum represents about one-third of the total expense of the work. As yet the canal has paid interest on about only one-third of the loan capital, and nothing to the stockholders; but it has been estimated that the saving in freight rates on Manchester goods amounts to $\$ 5,000,000$ per annum. Manchester is also represented on the joint committee for the improvement works and control of the Mersey and Irwell.

Improvements and steamboat landings on the river Thames are under the control of the Thames Conservancy Board. This consists of thirty-seven members, most of whom are representatives of the various municipalities along the river : the London County Council, the City of London, the boroughs of Oxford, West Ham, and Reading, and the several county councils. The remaining members are selected by the Admiralty, Board of Trade, the ship-owners, dockowners, and water companies. This board has, however, no jurisdiction over the great docks of London for foreign shipping, which are owned by private corporations.

The harbor boards for most of the other port towns contain representatives from the local municipalities: as in 
Belfast, Dublin, Plymouth, Newcastle, Swansea, Burnley, Gateshead, and South Shields. The Southampton Harbor Board is practically identical with the town council, while the Bristol and Portsmouth councils have direct control of local docks, but in these cases there are also important private or government docks.

Municipal docks and harbors are also frequent in Germanic cities. Those of Hamburg are as extensive as the Glasgow works; and with their network of railroads, their storage warehouses and handling equipment, are said to offer the best handling facilities in the world. The docks at Antwerp also deserve special mention. The modern works were begun by Napoleon during the French occupation, and in 1815 they were handed over to the municipality. New works were begun in 1856, and since then there have been further extensions and additions to the docks by the municipality to keep pace with the recent development of the commerce. The wharves along the river front belong to the Belgian government. Other important municipal works of this character are to be found at Amsterdam, Bremen, and Danzig. The river wharves at Cologne, Mainz, and other German cities are owned by the municipalities; while Vienna and Budapest have expended large sums on the improvement of the Danube.

In other European countries both harbor improvements and docks are for the most part constructed and owned by the central governments. This is the case in France, Italy, Austria, Russia, and Greece. The same system is followed in Australia and other outlying British possessions. In France a few of the river cities, such as Lille and Roubaix, own the local steamboat wharves.

Harbor improvements and docks in the United States fall into two distinct classes. The works connected with deepening channels are mainly carried out by the national government, under the direction of the corps of engineers of the United States army, and are paid for from the general funds of the United States treasury. Docks and wharf facilities, on the other hand, belong generally either to private parties or 
to municipalities, and the national government owns only such docks and wharves as are necessary for the use of the government navy.

By far the most important case of municipal ownership of docks is that of New York city. The charter of 1730 granted to the city the entire water front of Manhattan Island. But for 140 years there was no municipal or systematic construction of docks. Sites were leased and occasionally sold, and the docks were built and managed by private parties. In 1870 a department of docks was established, consisting of three commissioners appointed by municipal authority; and since then extensive construction schemes have been carried through. The comparatively small tidal change at New York renders unnecessary the enclosed docks such as exist at European ports. The plan under construction includes a broad "street" 250 feet wide, enclosed by a bulkhead. From this bulkhead are built, on wooden piles, piers (some as long as 800 feet) covered with two-story sheds. The total expenditure since 1870 has been over $\$ 30,000,000$, and the annual income from the leases of wharf property is about $\$ 2,000,000$. Transfer machinery and railroad facilities are very deficient compared with those of the great European ports, or at the docks of the transportation lines on the American lakes, although New York is about as well equipped as Boston and Philadelphia, where the wharves are, for the most part, owned privately. The extension of wharf facilities is hampered by the necessity of securing legislative authority for each extensive scheme, and by including the debt incurred for dock construction in the municipal debt, the total of which must be kept within the constitutional limit of 10 per cent.

The wharves at San Francisco are under the control of a state board of harbor commissioners; while at Boston there is a state board, and at Philadelphia a municipal board, which has supervision over wharf construction. A number of river cities own the steamboat landings on the river front. St. Louis has a gross income of $\$ 64,000$ a year from this source, and New Orleans has $\$ 40,000$ a year. Other cities in this 
group are Pittsburg, Allegheny, Louisville, St. Paul, Memphis, and Nashville. In other cases the municipalities own a small amount of wharf property : for example, Chicago, Philadelphia, Boston, Baltimore, Cleveland, Milwaukee, and Albany.

\section{MARKETS AND ABATTOIRS}

The market privilege was one of the earliest and most important factors in the mediæval municipalities of Central Europe. Many German cities can trace their markets back to the thirteenth century, and some as far back as the tenth. In France before the revolution the market privilege belonged to the seigneurs justiciers; but upon the abolition of their privileges, in 1790, the markets were taken in charge by the local authorities. In England the market privilege was a matter of grant, at first by the Crown, and later by Parliament; and such grants were formerly made to private individuals as well as to municipal corporations.

Originally these markets, in connection with fairs held at less frequent intervals, were the principal centres of trade, both wholesale and retail. They were generally held in the open air, and the activity of the municipality was confined to the collection of tolls, the regulation of business, and the maintenance of order. But with the development of trade in extent and complexity, one business after another has left the public market. At the present time in modern urban communities the market is simply the central location where the supply of perishable food products is brought for distribution. A central situation makes easier the sanitary inspection and control over the sale of fresh meats, game, fish, vegetables, and fruit.

Since the middle of the nineteenth century the erection of municipal market halls for the public markets has become general ; while more recently the erection of municipal abattoirs or slaughter-houses has become common. The Halles Centrales at Paris were begun in 1854 , and now cover an area of twenty-two acres, while that municipality maintains also nearly a hundred retail markets in various parts of the city. 
Since the extension of the city boundaries, the private slaughter-houses in the suburbs have been suppressed, and the great municipal abattoir general at La Villette has been constructed. Other cities in France and Italy have followed the example of Paris ; and municipal market halls and abattoirs are to be found in most large cities in these countries. In German cities, market halls date only from 1875 , and in most cases they have been built since 1886. In the latter year the first housed market in Berlin was opened, while there are now fourteen different market buildings in different parts of the city, built at an aggregate cost exceeding $\$ 5,000,000$. In 1883 the Berlin municipal abattoirs, costing nearly $\$ 5,000,000$, were opened, supplanting nearly a thousand private slaughter-houses. The municipal abattoirs of Munich, opened in 1887, abolished eight hundred small private establishments. The most important instance of a private market in continental Europe is at Antwerp. The Brussels Council leases the market of that city en bloc, but regulates the tolls and charges of the lessee.

In Great Britain municipal markets are not universal; but they are by far the most common system in the boroughs and other urban districts, as is shown in the following table for England : ${ }^{1}$ -

\begin{tabular}{l|r|r|r|r|r}
\hline \hline Markets in the Control of & London & Boroughs & $\begin{array}{r}\text { Urban Dis- } \\
\text { tricts not } \\
\text { Boroughs }\end{array}$ & $\begin{array}{r}\text { Rural } \\
\text { Districts }\end{array}$ & Total \\
\hline Local authorities . . & 8 & 216 & 89 & 8 & 313 \\
Trading companies . & 2 & 12 & 34 & 18 & 64 \\
Private persons. . . & 2 & 23 & 109 & 142 & 274 \\
Other bodies of persons & 1 & 4 & 11 & 24 & 39 \\
Quasi market rights . & & 1 & 11 & 10 & 22 \\
No markets.... . . & & 5 & 12 & 40 & 57 \\
Totals... . . . & 13 & 261 & 266 & 242 & 769 \\
\hline
\end{tabular}

The principal London markets belong to the city corporation, which derives from them a net profit of $\$ 230,000$, out of a total income of nearly $\$ 1,000,000$. Only five of the county

1 Report of Royal Commission on Markets. 
boroughs do not have municipal markets. The most important private markets are in Sheffield, where the Duke of Norfolk holds the market privilege. The ten municipal market buildings in Manchester have cost nearly $\$ 750,000$, and the seven markets of Birmingham about $\$ 400,000$. Municipal abattoirs are found only in about two-thirds of the boroughs having over 100,000 population, and but seldom in smaller places.

In Canada, Australia, and South America, municipal markets and (in the large cities) municipal abattoirs are the prevailing system. The markets of Sydney are valued at $\$ 3,750,000$.

The market system of the United States rests on an entirely different basis from that in the countries mentioned. While the municipal authorities generally have municipal markets, the monopoly privilege is not often found; and there are a number of important cities and many small cities with no municipal markets. In the latter class are San Francisco, Jersey City, Louisville, Rochester, and Providence. Chicago, Omaha, and Albany have public market-places, but no municipal market buildings. The most important municipal markets are those of New York city, where the gross revenue from the thirteen buildings is $\$ 450,000$. In New Orleans, where the city has a monopoly privilege, it receives from the lessees $\$ 226,000$ a year. The Quincy Market of Boston is valued at $\$ 1,250,000$, and produces an annual income of $\$ 84,000$, of which $\$ 60,000$ is net. Baltimore has a revenue of $\$ 59,000$ from its markets; and most of the other important cities receive smaller sums. Of cities having a population of between 25,000 and 100,000 , only about onethird have municipal markets; while no United States city has a municipal abattoir.

\section{CEMETERIES AND BURIALS}

Outside of Germany and Holland, practically all the cemeteries in the cities of continental Europe belong to the municipalities, and only occasionally are there non-municipal cemeteries, for non-Catholic classes. In Germany, Holland, 
and also in Great Britain, there are municipal cemeteries in almost every city; but there are also some exceptions, - for example, Cologne, Dresden, and Altona; while in other cases the municipal cemeteries are no longer in use for burials; and in most of the large cities there are private cemeteries in addition to those under public control. In Hamburg there is but one municipal cemetery as against fifteen under private control, and only six German cities of over 50,000 population have no private cemeteries. In Great Britain private cemeteries are more frequent than in Germany, while the public cemeteries are often under the management of a burial board independent of the other municipal authorities.

United States cities generally depend upon private cemeteries. Half of the cities with over 25,000 population, and two-thirds of those with over 100,000, have no municipal cemeteries except for the burial of paupers; while in most of the cities with municipal cemeteries there are also large private burying-grounds.

In some cities of continental Europe, the municipalities conduct the entire work of burial as a public function. Among these are Cologne, Dresden, Mainz, Rome, Naples, Milan, and Ghent. A few Swiss towns and also the city of Basel perform this work free of charge.

\section{MUNICIPALIZATION OF COMMERCIAL UNDERTAKINGS}

The difficulties and limitations of comparison of private with municipal undertakings are numerous. In the first place, undertakings which are municipalized, or which it is proposed to municipalize, have, in addition to the purely business side (profit and loss), an important social aspect; and municipal control means in almost every case a greater degree of attention paid to these social aspects, such as better facilities to the consuming public and better compensation to the employees. This amelioration of social conditions cannot be balanced in figures against diminished profits.

Assuming, however, the municipal works operated on a 
purely business basis, exact statistical comparisons are rarely practicable with any figures at hand. In some cases comparisons are made of prices charged by private companies with the cost of municipal operation, while it is clear that interest, taxes, and depreciation of plant and equipment must also be included. Interest and taxes can sometimes be accurately ascertained, but it is most difficult to learn anything definite concerning depreciation, as it requires exact knowledge of the particular plants, and cannot be determined with accuracy by estimating with any universally applicable rate per cent.

Even if these difficulties were removed, there still remains the important fact of different conditions in different places. Prices of raw material vary, local difficulties may add to the cost of construction works. In comparing the social benefits, prices may be on entirely different bases. Take, for example, the subject of water rates: these may be based in one town upon the quantity of water used as measured by meter, and in another upon a fixed rate per house; of two towns both using the meter method of estimating charges, each may have adopted a different point of measurement; and of two towns both using a fixed rate per house, the word "house" may mean a different thing in each. Street car tolls offer the same obstacle : a fixed street car rate cannot be compared with a rate varying according to the distance travelled. Finally, as between different countries, and to some extent also between different cities in the same country, there are important differences in the purchasing power of money and in customs, which seriously affect comparisons. For instance, the street railway traffic in England cannot be compared with that of the United States, on account of the differing degrees of density of population, and of differences in the value of money, and in the rates charged and facilities offered by other means of locomotion, such as cabs and steam railroads.

The question for or against the municipalization of commercial undertakings must, then, be decided largely on general grounds. The most important consideration is that of the 
social benefits to be derived from municipal control; and the strength of this argument, positively or negatively, will depend on public sentiment as to how far improved conditions should be furnished at the expense of general taxation. From a purely business standpoint, there are certain advantages in favor of either municipal or private control. Municipalities have the advantage of lower rates of interest on capital than private companies, and furthermore they issue no watered stock on which interest must be paid. On the other hand, private companies are in general willing to pay much higher wages of superintendence than municipalities, thus securing the most efficient management, while at the same time the non-technical management (usually a board of directors) is more permanent, and so more likely to pursue a continuous policy.

These are the principal permanent features. Other arguments against municipalization are the spoils system and municipal corruption. As to the first, its existence is bound to add much to the expense, and to detract from the efficiency of municipal work; but we seem to have passed the period of wholesale removals of subordinate employees with each change of administration, and this is no longer a vital matter. In regard to corruption among the managing officials, it may be noted that dishonest and corrupt practices of directors in private companies are by no means unknown. Moreover, one of the chief sources of municipal corruption in the past has been in connection with franchises to private corporations; while with municipal ownership, not only would the added importance and responsibility of municipal work tend in some degree to secure better municipal officials, but also those citizens who as officers of corporations were formerly interested in securing the best terms for their company become, as taxpayers, interested in obtaining the most efficient management, and are likely to use their influence in the interest of better government.

A practical factor to be borne in mind in the United States is the existence of constitutional debt limits, which place an effective check on municipal activity. As it is more impor- 
tant that a city should not neglect the works in which it is engaged than that it should undertake new works, care must be taken not to take up new lines of activity which will bring the debt so close to the limit as to hamper the development of other undertakings. Thus it is very doubtful if New York, with the works of water supply, docks, and the rapid transit tunnel under way, could take up the construction of gasworks or surface railways (or could undertake the purchase of existing plants) without intrenching on the debt limit and stopping other needed improvements. Even where the debt limit is not in question, too many new undertakings might retard the development of municipal works.

Conclusions. - 1. Where a private company has shown itself well managed and active in the public interest, it seems doubtful policy to run the risk of a less able management under municipal control; but agreements even with such a company should be carefully drawn to safeguard the interests of the city.

2. In the case of franchises granted without proper provisions, the first step to be taken is to compel the reduction of rates or an improvement in facilities, so that the company will receive only a fair income from its property. If this is not done, little will be gained by a municipal purchase of the plant at the swollen values due to the high rates charged.

3. After such reduction in rates, or upon the expiration of a franchise in a city which has managed other public works with success, and is not already involved in as many undertakings as it can manage, municipal ownership of monopolies is advisable. 



\section{PART III}

MUNICIPAL FINANCES 



\section{PART III - MUNICIPAL FINANCES}

\section{CHAP'TER XIII}

\section{Municipal Expenditures}

Authorities. - G. Cadoux : Les Finances de la ville de Paris, 1789-1900 (Essay on municipal finances of other cities).-L. PAUL-DUBors : Essai sur les finances communales. - O'Mrara: Local Taxation at Home and Abroad. - C. H. Bldnder : Local Taxation and Finance.Edwin Cannax: History of Local Rates in England.-Reports of the Local Government Board. - Reports on Local Taxation by George J. Goschen (1870) and H. H. Fowler (1889) in Parliamentary Papers, 1898, Vol. 77. - Situation financière des communes en France, 1899. - Report of Poor Law Commissioners on Local Taxation, 1843. A. G. Desnats: Le Budget Municipal. - Journal Royal Statistical Society, 5:97-168; 58:327 ; 63:367. - Economic Journal, June, September, 1899. - Zeitschrift fur die Staatswissenschaft, $55: 510$. Contemporary Reviewo, 34:678-697. - Political Science Quarterly, $78: 268$.

A DETAILED study of municipal expenditures involves an investigation into the whole field of municipal activity, such as has been attempted in the preceding chapters. This chapter rather attempts to look at the net results of municipal activity as one whole, signified by the sum total of expenditures for all purposes. Only in some of the broadest features will it be possible to indicate the relative importance of the different objects of expenditure.

As a further preliminary, it should perhaps be repeated that the word "municipal" is used in a broad sense. In Great Britain regularly, and in America frequently, there are several local corporations in the larger communities, only one of which is spoken of as the "municipal corporation." Not only such "municipal corporations," but all these local authorities will be considered whose functions are related to the municipal authorities in such a country as Germany, 
where the municipal council is the general agency for all the local interests.

Any one at all aware of the extraordinary development of cities and of municipal activities during the nineteenth century, and especially during the latter part of it, is doubtless somewhat prepared to hear of a vast increase in the total expenditures. Yet even such an one will probably be startled at the figures which appear for the various countries. The first table presents statistics for the various local authorities in England and Wales, showing the increase in local taxation since 1803, and the total local expenditure since $1868:{ }^{1}$ -

\begin{tabular}{c|r|c}
\hline Year & Local Rates & $\begin{array}{c}\text { Local Expenditures } \\
\text { (including Loans) }\end{array}$ \\
\hline 1803 & $£ 5,348,000$ & \\
1817 & $10,107,000$ & \\
1841 & $8,108,000$ & \\
1862 & $12,207,000$ & \\
1868 & $16,783,000$ & $£ 30,454,523$ \\
1883 & $24,470,790$ & $53,420,923$ \\
1893 & $30,206,484$ & $66,890,962$ \\
1897 & $35,898,774$ & $78,523,271$ \\
1899 & $38,602,673$ & $92,696,586$ \\
\hline
\end{tabular}

During the century the population of England and Wales has slightly more than trebled, but the taxes collected by local authorities have multiplied nearly sevenfold. In the four decades since 1862, the total population has gained 50 per cent, and the local taxes and local expenditure have trebled. The per capita taxation has increased in the century from $\$ 1.50$ to $\$ 6.25$. The aggregate local expenditure, which now is much larger than the local taxation, has more than trebled since 1868, while population has increased in that period by less than 50 per cent.

No less significant figures are presented from France for the period from 1836 to 1899 :-

1 Reports on Local Taxation by George J. Goschen (1871) and H. H. Fowler (1893), and Local Taxation Returns in Parliamentary Papers. 
ORDINARY EXPENDITURES OF FRENCH COMMUNES 1

\begin{tabular}{c|c|c|c}
\hline Year & Paris & Other Communes & Total \\
\cline { 2 - 3 } & francs & francs & francs \\
1836 & $36,600,000$ & $83,830,926$ & $120,430,926$ \\
1859 & $51,970,000$ & & \\
1869 & $131,485,000$ & & \\
1881 & $222,778,007$ & & \\
1891 & $264,691,174$ & $376,927,942$ & $641,619,116$ \\
1899 & $304,372,669$ & $426,015,996$ & $730,388,665$ \\
\hline
\end{tabular}

While population has gained one-sixth, municipal expenditures have increased six times. The population of Paris has trebled, and the public expenditures have gained eight times, the increase being distinctly since 1859. Nine large cities next in rank, with an aggregate population in 1871 of $1,378,457$, expended $28,066,497$ francs ; in 1899 , with a population of $2,020,905$, the aggregate expenditure for the same cities was $62,236,775$ francs.

For other countries, no such long-period comparisons are available; and for some no complete figures even for recent years are at hand. The general tendency may, nevertheless, be indicated by the statistics furnished:-

BELGIAN COMMUNES

\begin{tabular}{c|c|c}
\hline \hline & 1865 & 1892 \\
\hline & Items & francs \\
Ordinary expenditure . . & $38,589,914$ & $117,144,576$ \\
Extraordinary expenditure & $34,760,205$ & $62,172,216$ \\
Total . . . . . . & $73,350,119$ & $179,316,792$ \\
\hline
\end{tabular}

This increase of more than 100 per cent in local expenditures has been accomplished by a gain in population of 25 per cent.

In Italy the total expenditure of the communes has risen from $325,363,613$ lira in 1871 to $545,385,242$ lira in 1897 , in spite of the pressure of national taxation, which has seriously

1 Paul-Dubois: Essai sur les finances communales; Situation financière des communes, 1899. 
limited the possibilities of imposing further burdens for local improvements. For Germany the following statistics, ${ }^{1}$ showing the municipal revenue from the land tax (Grundsteuer) in Saxony, illustrate the same tendency:-

\begin{tabular}{c|c|c|c}
\hline \hline Year & Cities & Rural Communes & Total \\
\cline { 2 - 4 } & marks & marks & marks \\
1844 & $11,774,228$ & $36,719,001$ & $48,493,279$ \\
1897 & $47,268,013$ & $44,345,498$ & $91,613,511$ \\
\hline
\end{tabular}

For some other countries, where no general statistics are available, statistics for single cities must be used. The following figures will show the same marked advance in municipal expenditures throughout Europe, and even in the awakened Japan :-

\section{MUNICIPAL EXPENDITURES 2}

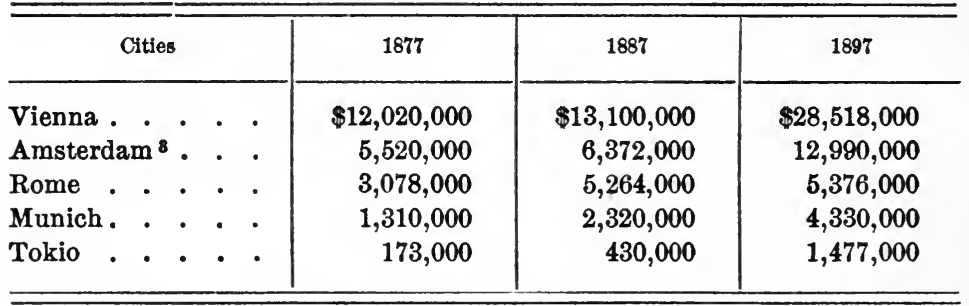

If there were records of the aggregate municipal expenditure in the United States from the beginning of the nineteenth century, they would show an even more astonishing development than in other countries. This, however, would be in large part due to the primitive conditions and insignificant expenditures at the beginning of the century. But even during the later decades the increase in municipal expenditure, as indicated by the local taxation, is more marked than in any other country. Note the following statistics: ${ }^{4}$

\footnotetext{
1 Revue générale d'administration, Vol. 66, p. 75.

2 Cadoux: Les Finances de Paris.

8 Statistics for 1878, 1888, 1898.

- From United States Census reports.
} 
UNITED STATES

\begin{tabular}{c|c|c|r}
\hline \hline Year & Municipal Taxation 1 & $\begin{array}{c}\text { State, County, and } \\
\text { Municipal Taxation }\end{array}$ & $\begin{array}{c}\text { Estimated True } \\
\text { Valuation of Property }\end{array}$ \\
\cline { 2 - 3 } 1860 & & $\$ 94,186,746$ & $\$ 16,159,000,000$ \\
1870 & $\$ 134,794,108$ & $280,591,521$ & $30,068,000,000$ \\
1880 & $190,874,968$ & $313,921,474$ & $43,642,000,000$ \\
1890 & $306,099,783$ & $471,345,140$ & $65,037,000,000$ \\
\hline
\end{tabular}

From 1860 to 1890 , while the population doubled and the estimated value of property increased fourfold, the total of state and local taxation gained fivefold. The figures for 1870 are currency values, inflated by the gold premiums; but without making any allowance for that, municipal taxation in 1890 was two and a half times that of 1870. The aggregate expenditures is always in excess of the taxation, and in 1890 the municipal expenditure was $\$ 423,667,503$.

For a few of the larger cities the development of expenditure can be shown for a longer period, as in the following table for New York, Baltimore, Boston, and Detroit :-

\section{MUNICIPAL EXPENDITURES : AMERICAN CITIES}

\begin{tabular}{|c|c|c|c|c|c|c|c|c|}
\hline \multirow[b]{2}{*}{ Year } & \multicolumn{2}{|c|}{ New York ${ }^{2}$} & \multicolumn{2}{|c|}{ Baltimore $^{3}$} & \multicolumn{2}{|c|}{ Boston 4} & \multicolumn{2}{|c|}{ Detroit ${ }^{5}$} \\
\hline & Amount & $\begin{array}{l}\text { Per } \\
\text { Cap. }\end{array}$ & Amount & $\begin{array}{c}\text { Per } \\
\text { Cap. }\end{array}$ & Amount & $\begin{array}{c}\text { Per } \\
\text { Cap. }\end{array}$ & Amount & $\begin{array}{l}\text { Per } \\
\text { Cap. }\end{array}$ \\
\hline & $\$$ & $\$$ & $\$$ & $\$$ & $\$$ & $\$$ & $\$$ & $\$$ \\
\hline 1798 & 108,000 & 1.80 & 64,381 & 2.47 & & & & \\
\hline 1830 & 676,018 & 3.43 & 3.31,392 & 4.17 & & & & \\
\hline 1840 & $1,605,742$ & 5.13 & 442,006 & 4.33 & & & & \\
\hline 1850 & $3,368,163$ & 6.53 & 687,972 & 4.07 & & & & \\
\hline 1860 & $8,473,657$ & 12.14 & $2,875,774$ & 13.56 & $3,578,372$ & 20.00 & 205,445 & 4.50 \\
\hline 1870 & $26,532,761$ & 28.14 & $5,270,621$ & 19.74 & $12,866,176$ & 28.14 & 710,660 & 8.93 \\
\hline 1880 & $29,754,553$ & 24.66 & $6,081,171$ & 18.32 & $12,200,398$ & 23.62 & $1,004,634$ & 8.63 \\
\hline 1890 & $34,985,680$ & 23.09 & $7,599,763$ & 17.51 & $17,965,443$ & 39.84 & $2,545,327$ & 12.36 \\
\hline 1899 & $93,520,082$ & 27.21 & & & $24,768,092$ & 44.02 & $3,662,877$ & 12.82 \\
\hline
\end{tabular}

1 Including school districts.

2 Durand: Finances of New York City; Report of Comptroller, 1899. These figures include state taxes collected in the city.

$3 \mathrm{~J}$. H. Hollander: The Financial History of Baltimore.

- N. Matthews : City Government of Boston; Auditor's report, 1899-1900.

6 Report of the Controller, 1899-1900. The last figures are for 1900. 
Here, again, it is necessary to bear in mind the gold premium which increased the currency expenditure in 1870; while in the case of New York the expenditures for that year and neighboring ones were also largely increased by the operation of the Tweed Ring.

Comparisons between the total municipal expenditures in various countries are of limited value. The per capita expenditure, for example, will vary with the proportion of urban population, with the relative distribution of urban population between cities of various grades, and also with the degree to which different functions are performed by the municipal authorities in different countries and cities. The figures will therefore indicate the net results of a series of complicated factors, and can be interpreted only in a general way. The table below gives a general comparison of the countries for which figures are available, with data taken as nearly as possible for the same year :-

COMPARISON OF TOTAL MUNICIPAL EXPENDITURES

\begin{tabular}{|c|c|c|c|c|}
\hline Country & Year & Population & Amount & Per Capita \\
\hline United States . . & 1890 & $62,622,250$ & $\$ 423,667,503$ & $\$ 6.80$ \\
\hline England and Wales & 1890 & $29,002,525$ & $290,920,930$ & 10.03 \\
\hline Italy . . . . & 1891 & $29,699,785$ & $105,940,686$ & 3.53 \\
\hline France . . . & 1891 & $38,343,192$ & $128,323,823$ & 3.34 \\
\hline Belgium . . & 1892 & $6,030,043$ & $35,863,338$ & 5.97 \\
\hline
\end{tabular}

The United States holds first position in the gross amount of expenditure mainly because it has so much larger population than the other countries in the list. The per capita figure for England and Wales is distinctly the highest, and presents a striking illustration of the large proportion of urban population and the great development of municipal activities in the English towns. Belgium is somewhat below the United States in per capita expenditure, but in relative urban population and municipal activities Belgium is the more advanced of the two, and the higher figure in the United States is to be ascribed mainly to a higher scale of 
money expenditure for the same services. A study of urban population and municipal activities in Germany indicates that it would fall in the same group with the United States and Belgium. France and Italy are distinctly below the other countries, illustrating at the same time the smaller development both in urban population and in municipal action. As between these two countries there is comparatively little difference in the general result. While France has in Paris one of the four most important municipal centres in the world, it has few other cities of importance; and Italy has a number of cities in the second rank.

Of greater value than the comparison just made would be a study of the expenditures for different purposes and the relative importance of the various objects of expenditure in the various countries. Here, however, the investigation is limited by the lack of detailed and classified statistics. Complete statistics classifying expenditures in any systematic fashion are available only for England and Wales, the United States, and Italy; while even in these cases the bases of classification are so different that comparisons between them are difficult. Some points may, however, be brought out by the following tables:-

\section{LOCAL EXPENDITURES : ENGLAND AND WALES}

Excluding Receipts from Lonks

\begin{tabular}{|c|c|c|c|c|}
\hline Items & $1883-1884$ & $1887-1888$ & 1892-1893 & $1897-1898$ \\
\hline Police and Care of Prisoners & 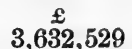 & 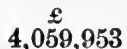 & $\stackrel{\stackrel{2}{\sharp}}{4,797,867}$ & $5.019,417$ \\
\hline Fire Brigades . . . . . & 194,672 & 203,300 & 255,802 & 349,398 \\
\hline Poor Relief. & $6,775,478$ & $6,687,396$ & $7,184,158$ & $8,297,668$ \\
\hline Insane Hospitals . & $1,418,431$ & $1,456,251$ & $1,766,932$ & $2,069,859$ \\
\hline Education (Schools) & $2,876,119$ & $3,766,048$ & $5,425,341$ & $7,806,102$ \\
\hline Libraries and Museums & 129,743 & 188,120 & 285,334 & 378,128 \\
\hline Streets and Roads . & $5,544,832$ & $5,585,443$ & $7,247,853$ & $8,032,313$ \\
\hline Bridges and Ferries . & 111,641 & 199,795 & 177,249 & 206,035 \\
\hline Parks and Open Spaces & 140,977 & 188,120 & 346,139 & 519,423 \\
\hline Sewerage and Drainage. & 814,744 & 957,329 & $1,223,836$ & $1,562,667$ \\
\hline Waterworks . . . & 856,360 & 879,167 & $1,010,008$ & $1,284,478$ \\
\hline Gasworks • • • & $2,359,828$ & $2,509,722$ & $3,480,925$ & $3,956,793$ \\
\hline Other Public Lighting & 862,570 & 905,656 & $1,063,990$ & $1,501,454$ \\
\hline Markets and Fairs . & 278,783 & 284,973 & 324,383 & 375,665 \\
\hline Slaughter-houses . & 16,241 & 14,507 & 19,242 & 27,143 \\
\hline
\end{tabular}




\section{LOCAL EXPENDITURES (Continued)}

\begin{tabular}{|c|c|c|c|c|c|}
\hline Items & & 1883-1884 & $1887-1888$ & 1892-1893 & $1897-1898$ \\
\hline Cemeteries & & $\begin{array}{c}£ \\
233,768\end{array}$ & $\stackrel{\stackrel{E}{248,743}}{ }$ & $\stackrel{f}{ \pm}$ & $\stackrel{f}{\stackrel{f}{347,889}}$ \\
\hline Public Baths & & 113,902 & 120,815 & 209,844 & 296,284 \\
\hline Dwelling Imp't Schemes & & 98,575 & 24,235 & 42,227 & 42,388 \\
\hline Allotments . . . & & & & 8,899 & 45,138 \\
\hline Harbors, Piers, Docks & & $1,460,020$ & $1,312,731$ & $1,660,920$ & $1,624,569$ \\
\hline Tramways . . . & . & & 20,545 & 51,818 & 342,576 \\
\hline Other Public Works. & & $2,262,492$ & $2,173,338$ & $2,963,119$ & $4,051,807$ \\
\hline Private Imp't Works & & 592,289 & 548,160 & 766,218 & $1,006,156$ \\
\hline Interest and Loans & . & $9,808,144$ & $10,693,124$ & $11,909,913$ & $14,218,949$ \\
\hline Salaries, not itemized . & & $1,750,776$ & $1,912,696$ & $2,312,205$ & $2,824,915$ \\
\hline Legal and Parl. Expense & & & 119,153 & 151,845 & 204,305 \\
\hline Public Buildings . . & & 193,723 & 182,963 & 242,185 & 293,914 \\
\hline Other Payments & & & & 465,837 & 588,684 \\
\hline Total. . & & $43,378,267$ & $45,834,026$ & $56,052,721$ & $\overline{67,823,716}$ \\
\hline
\end{tabular}

MUNICIPAL EXPENDITURES: UNITED STATES CITIES-1890

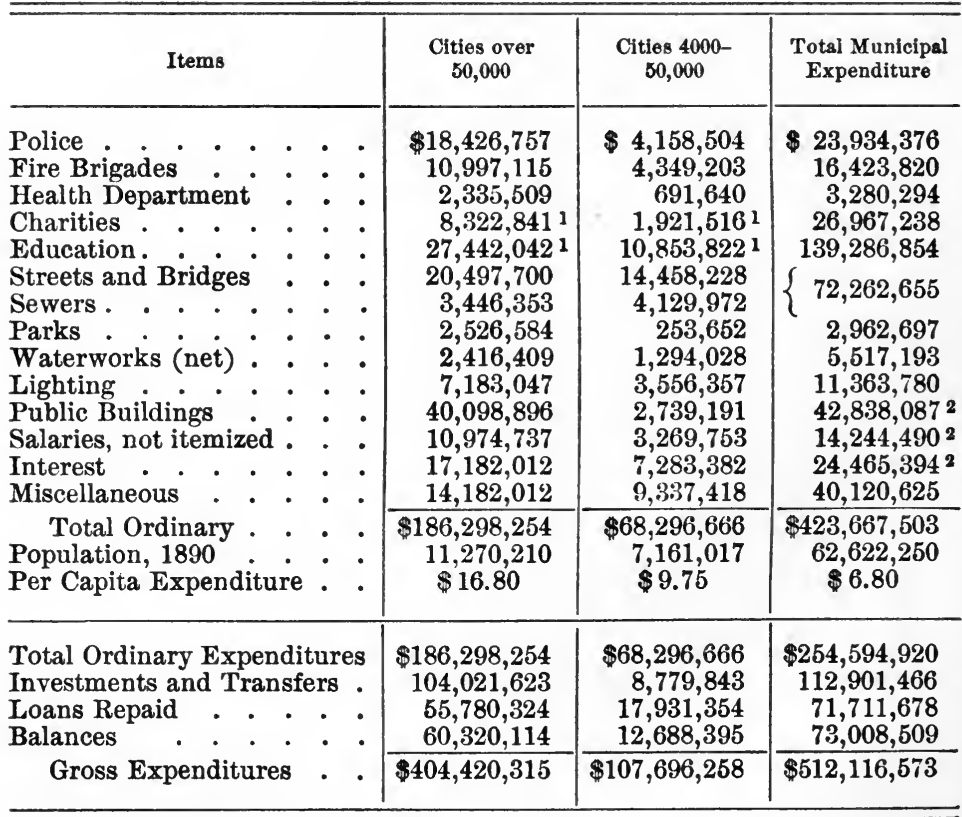

1 Excluding expenditure by other authorities than the city corporations.

2 Expenditure for cities with over 4000 population. 
MUNICIPAL EXPENDITURES : ITALY 1

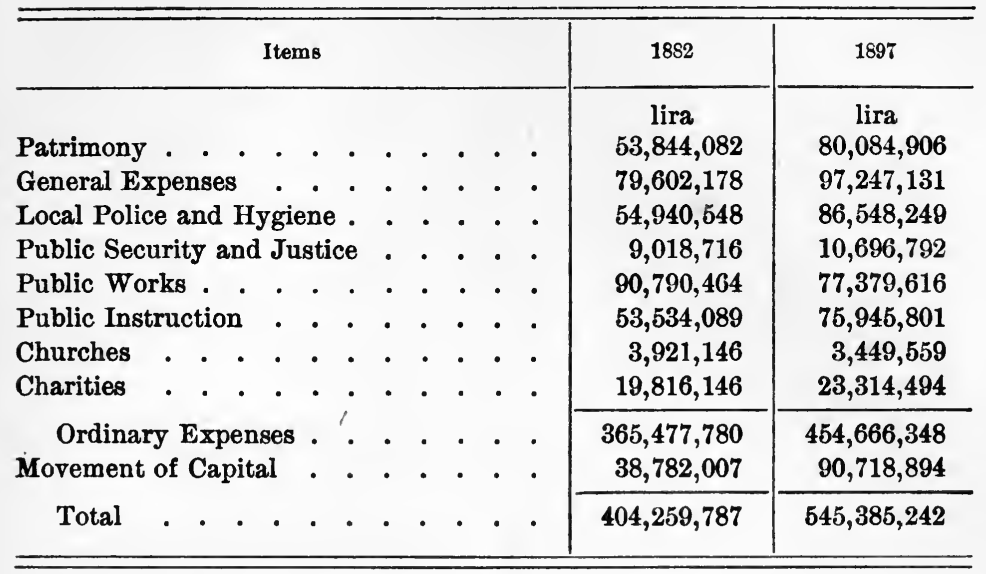

The amount expended for police purposes in England and Wales is about the same as in the United States. But for the United States this is only 5 per cent of the total expenditure, while for England it is 8 per cent; and in Italy 16 per cent of the municipal outlay is for police purposes. The per capita expenditure for the whole population is not significant; but the relative expenditure in proportion to the urban population is about the same for England and the United States, and distinctly higher for Italy. This indicates a general similarity in the police expenditures of the two former countries, while the larger ratio to total expenditure for England shows that other items of expenditure are not so important there as in the United States. In Italy the police expenditure is not only a larger share of the total than in either England or the United States, but is also markedly higher in proportion to urban population than in either of the other countries. The expenditures for fire brigades in the United States are many times those for the same purpose in England and Wales, and the differences here illustrate the remarkable development of fire brigades in this country.

1 Bilanci Comunali per l' anno 1897. 
In the group of public works, the differences in classification makes possible comparisons only in regard to streets and roads and parks. In both departments the total expenditures in the United States are notably larger than in England. On streets and roads the proportion of total expenditure and per capita outlay in the two countries is about the same; but it is difficult to draw any definite conclusions, because it is impossible to distinguish in the English statistics between the city streets and country roads. For parks, the expenditure in American cities is seen to be much larger than in England, from every point of view.

For public charities the municipal expenditures in England and Wales are notably higher than in the United States; and in proportion to population the showing is even larger for the former country. This difference is due in part to the larger proportion of private charities in the United States, but doubtless also in part to a smaller need or demand for relief in this country. In Italy the municipal expenditures for charities are far less than those in the United States in proportion to population as well as in total amount. Private charities, especially endowed institutions, supply a large part of the needed alms, while the standard of need which will lead to public relief is undoubtedly much lower in Italy.

In the field of education the municipal expenditures for the United States are far and away the highest. They are five times those for England and Wales, and ten times those for Italy. Allowing for differences in population, the amount for the United States is still two and a half times that for England and five times that for Italy.

Turning from countries as a whole to particular cities, the number of municipalities which will receive special consideration is necessarily very small. The following table presents in some detail the ordinary expenditures for the five great metropolitan communities of London, New York, Paris, Berlin, and Chicago. These are the places where the problems of urban communities are most pressing, where municipal activities are most extensive, and where per capita municipal expenditures are the largest. 
MUNICIPAL EXPENDITURES: METROPOLITAN CITIES

\begin{tabular}{|c|c|c|c|c|c|}
\hline Items & London 6 & New York & Paris & Berlin & Chicago \\
\hline & $1897-1898$ & 1899 & 1898 & 1898-1899 & 1899 \\
\hline Police . . . & $\$ 8,009,630^{1}$ & $\$ 11,182,532$ & $\$ 8,175,000^{1}$ & $\$ 3,145,5421$ & $\$ 3,905,705$ \\
\hline Fire Brigade & 816,440 & $4,443,614$ & 518,303 & 690,000 & $1,648,494$ \\
\hline Streets and Parks & $8,960,735$ & $12,442,939$ & $5,079,500$ & $4,348,691$ & ${ }^{5} 2,584,088$ \\
\hline Sewers. . . & $1,835,970$ & 787,479 & 863,672 & $805,000^{2}$ & 382,967 \\
\hline Water Supply & & $2,201,780$ & $1,090,428$ & $2,125,000^{2}$ & $1,396,500$ \\
\hline Lighting . . . & $1,538,655$ & $1,290,463$ & $1,998,012$ & 539,198 & 520,931 \\
\hline Charities. . & $17,601,380$ & $4,982,478$ & $5,890,887$ & $2,732,200$ & \\
\hline Education . . & $13,520,355$ & $13,415,053$ & $5,465,643$ & $4,234,450^{2}$ & $7,030,776$ \\
\hline $\begin{array}{l}\text { Debt (Interest } \\
\text { and Payments) }\end{array}$ & $7,525,160$ & $23,476,840$ & $21,006,543$ & $8,893,850$ & \\
\hline $\begin{array}{c}\text { Total Ordinary } \\
\text { Expenses }\end{array}$ & $67,907,950$ & $87,244,422^{8}$ & $66,770,0004$ & $35,144,000$ & $19,744,267$ \\
\hline Municipal Debt & $243,206,515$ & $251,632,705$ & $443,000,000$ & $66,219,175$ & $29,163,723$ \\
\hline
\end{tabular}

1 Including state grants toward support of police : Berlin, $\$ 2,094,000$; Paris, $\$ 2,110,000$. Under London the amount given is not the entire cost of the Metropolitan Police, but only the proportionate share for the administrative county of London. 2 1897-1898.

3 Excluding state taxes, but including county expenditure.

4 Excluding $\$ 55,000,000$ for refunding municipal debt.

5 Expenditures of Park Boards not included.

6 PUBLIC EXPENDITURES IN LONDON-1897-1898

Excluding duplicates, and expenditures out of loans

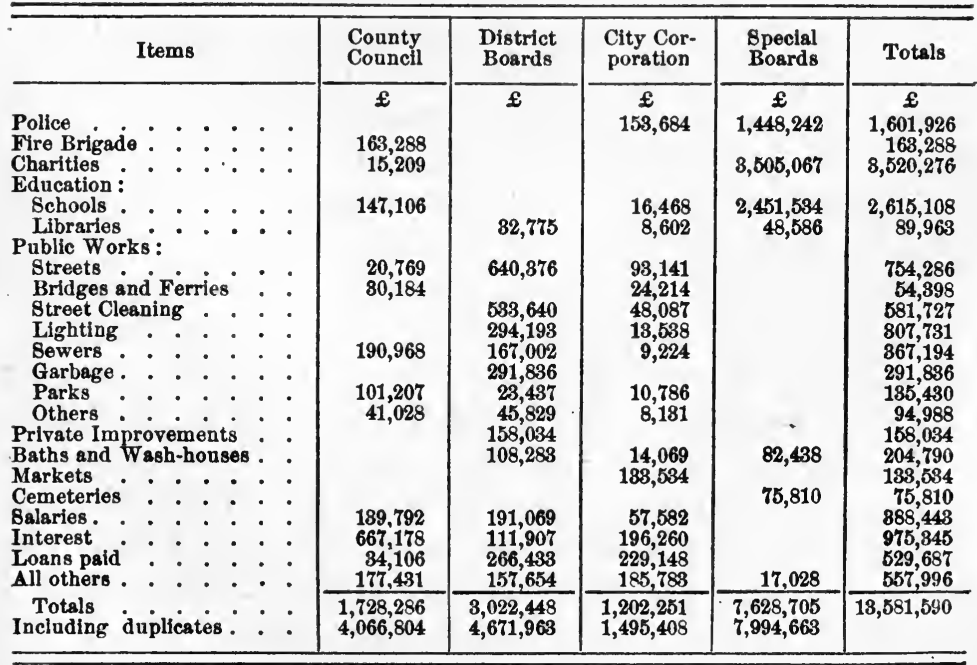


The expenditures for New York, Paris, and Berlin are readily obtained from the official reports of these cities, since there is in each case a central finance system for the whole community. In London, however, the financial authority is distributed among a host of officials ; accordingly, the figures here presented for London as a whole have been compiled from the reports of these officials to the Local Government Board. For Chicago only the figures of the city corporation are available; while in any comparison of total expenditures, the cost of the park boards and town governments in Chicago, and a large share of the expenses of Cook County and the sanitary district, should also be included.

It is obvious that the total expenditures here shown for Chicago cannot be compared with the totals for the other cities. Further, the fact that the London water supply is in private hands makes the London accounts deficient in that important item present in all of the other cities. Again, the New York total is necessarily higher than it should be for comparative purposes, on account of the expenditures on the municipal docks, for which there is no corresponding item in the other accounts; while the Berlin figures include expenditures for the municipal gasworks. These facts indicate some of the difficulties which make practically impossible any safe deductions from the aggregate expenditures in the different cities. The most that can be said is that, after making allowances for such important differences as are indicated above, the expenditures of Paris are largest in proportion to population of any of the cities in the list, those of New York second, and those of Berlin the lowest.

In the various items there are some significant contrasts between the various cities. The American cities spend proportionately much larger sums than the European cities for police, fire brigades, streets and parks, and schools; but it would require a more intensive investigation than can be made here to determine how far this is due to better equipment and higher rates of wages in this country, and how far it indicates extravagance or corruption. The London expenditures for poor relief are vastly greater than in the 
other cities; while Paris takes the lead in payments for public lighting and on account of its enormous debt, the legacy of the great improvement schemes in the French capital.

The next table presents similar data in reference to a larger number of cities which rank next to those just mentioned. Here again the difficulties of comparison and the dangers of hasty conclusions must be borne in mind, especially in reference to the totals for each city. But with this word of caution, the figures must be left to speak for themselves. The most striking fact is the large expenditures for Boston, which are higher in proportion to population even than those for Paris and New York.

\section{MUNICIPAL EXPENDITURES ${ }^{1}$ - 1898-1899}

(In thousands of dollars)

\begin{tabular}{|c|c|c|c|c|c|c|c|c|c|c|c|c|}
\hline 竎 & 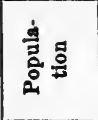 & 苚 & 氞 & $\frac{8}{0}$ & 密 & 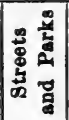 & 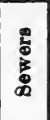 & 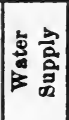 & 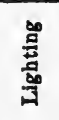 & 遏 & 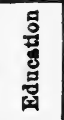 & 苍曾 \\
\hline Philadelphia & $1,298,697$ & 41,211 & 19,234 & 8464 & 990 & 1787 & 118 & 1811 & 1188 & 650 & 8412 & 8858 \\
\hline St. Louis & $\mathbf{5 7 5 , 2 3 8}$ & 19,10 s & 9110 & 1459 & 727 & 1012 & 90 & 609 & 417 & 627 & 1470 & 1278 \\
\hline Boston & 560,892 & 59,299 & 19,762 & 1830 & 1191 & 1688 & 850 & 983 & 678 & 795 & 2770 & 2017 \\
\hline Baltimore & 508,957 & 82,928 & T121 & 1079 & 491 & 801 & 18 & 902 & 895 & 808 & 1343 & 1920 \\
\hline Glasgow & 785,000 & 43,000 & & 679 & 110 & 900 & 228 & 1062 & 188 & $?$ & 1280 & 1580 \\
\hline Liverpool & 668,643 & 60,000 & & 880 & 115 & 860 & 110 & 1830 & 214 & $?$ & 660 & 2050 \\
\hline Manchester & 539,079 & 79,000 & & 280 & 56 & 1170 & 240 & $?$ & 230 & 860 & 425 & 2480 \\
\hline Birmingham & 510,343 & 48,000 & & 870 & 49 & 295 & 81 & $?$ & 117 & $?$ & 685 & 2150 \\
\hline Munich & 445,000 & 25,000 & 5320 & $?$ & 88 & 128 & $?$ & 274 & 274 & 805 & 1060 & 1040 \\
\hline Leipzig & 422,000 & 15,000 & 5110 & 710 & 104 & 156 & 28 & 280 & 580 & 448 & 1040 & 600 \\
\hline Dresden & 888,000 & 10,000 & 96540 & $?$ & $?$ & 221 & 84 & 80 & 260 & 868 & 1140 & 460 \\
\hline Amsterdam & 503,000 & 40,000 & 5570 & 440 & 120 & 880 & 88 & 299 & 172 & 502 & 1308 & 2170 \\
\hline Rome & 491,000 & 43,000 & 4840 & 812 & 52 & 865 & $?$ & 93 & 287 & n.m. & 603 & $?$ \\
\hline Brussels & 205,000 & 56,000 & 6000 & 278 & 67 & 192 & 24 & 140 & $?$ & 140 & 546 & 1860 \\
\hline Copenhagen & 849,000 & 16,600 & 8180 & 820 & 81 & 206 & $?$ & 86 & 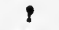 & 908 & 553 & 471 \\
\hline Barcelona & 520,000 & $?$ & 96180 & 386 & 49 & 816 & 85 & 82 & 275 & 170 & 160 & 1180 \\
\hline Madrid & 609,000 & 16,000 & 96050 & 210 & 104 & 875 & 88 & 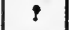 & $?$ & 204 & 232 & 1140 \\
\hline Lyons & 466,000 & $?$ & 2260 & 156 & 47 & 822 & 27 & 75 & 78 & 275 & 499 & 1072 \\
\hline Marseilles & 447,000 & 21,000 & 8250 & 284 & $?$ & 462 & 18 & 260 & 180 & 408 & 644 & 1235 \\
\hline Bordesux & 256,000 & 6,900 & 1780 & 200 & $?$ & 149 & 14 & 83 & 65 & 227 & 244 & 560 \\
\hline
\end{tabular}

1 Bulletin of the Department of Labor, September, 1900; Cadoux, Les Finances de Paris, 680, 698. 


\section{CHAPTER XIV}

\section{Municipal Debts}

THE subject of loans and debts must be considered somewhat apart from either that of expenditures or of revenues, because it has to do with both. The loan is in the first place a source of revenue, while the debt caused by the loan gives rise to a standing item in the list of expenditures. This dual nature of the subject suggests, too, its consideration as the transition from the subject of expenditure to that of revenue.

Municipal debts are not altogether a novel feature in municipal finance; but in their purpose and amount the municipal debts of to-day differ so radically from those of former periods that the recent changes are the most striking features of the present system. In former centuries debts were incurred by the localities to meet extraordinary demands from the Crown and to secure resources for carrying on military operations; debts were on the whole exceptional; standing debts were very rare; and the amounts of outstanding debt from the point of view of to-day were almost insignificant. At the present time the municipal debts are incurred for the erection of permanent works, so as to distribute the cost of construction over the period for which the works will be in existence. The principal objects of loans are (1) the commercial undertakings, such as waterworks and gasworks, which are directly reproductive; (2) street construction; and (3) public buildings, notably those used as public schools. In connection with the great development along these lines of municipal activity there has been a steady and rapid advance in the amount of municipal debt, especially in the last fifty years; and in 
every city of any importance a debt of a considerable amount is a permanent feature of the municipal financial system.

The large municipal works which inaugurated this borrowing on a large scale began about the middle of the nineteenth century, but the progression has continued without any cessation up to the present time. In England the amount of municipal debt has trebled since 1875; in France it has increased by two-thirds since 1868; in the United States it more than doubled between 1879 and 1890 ; and in every country the amount of municipal debt is large, and gives rise to serious problems.

In the following table aggregate statistics of municipal debt for the most important countries are presented : -

STATISTICS OF MUNICIPAL DEBTS

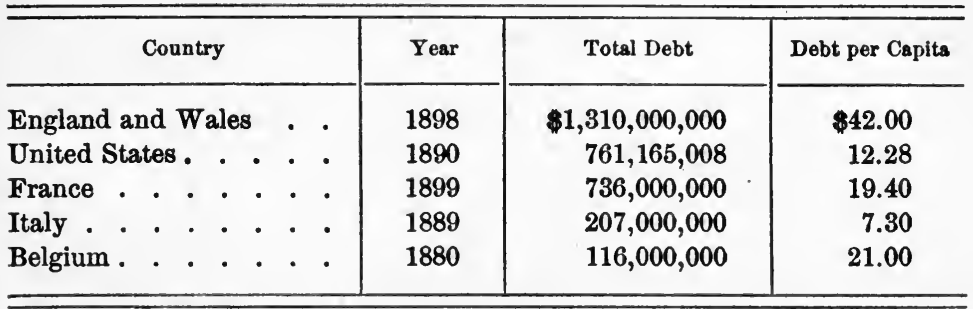

This shows that the largest gross and proportionate debt is in England, and that country has nearly double the per capita rate of Belgium, where the next largest proportionate debt is found. The per capita debt of France is slightly lower than that of Belgium, the United States ranks fourth in this regard, while Italy has the lowest per capita of the countries named. Germany probably holds about the same relative position as the United States.

A striking feature of this subject is the large number of small municipalities which have incurred debts within recent years. In France in 1862 only 12 per cent of the communes had any indebtedness; while by 1890 the percentage had increased to 73. In Italy in 187740 per cent, and in 1889 64 per cent, of the total number of the communes had debts ; while in the Province of Rome only 14 out of 227 communes had no debts at the latter date. 
Nevertheless, the great bulk of the municipal debt, like the bulk of the expenditure, is that of the large cities. In France the debt of Paris represents more than half of the total; the debt of cities containing more than 50,000 inhabitants is 74 per cent of the total; and of 246 towns, with an aggregate of one-quarter the total population of the country, is 84 per cent of the total. In Italy the debt of 395 towns, each with more than 10,000 population, amounted to 81 per cent of the total debt; and the debt of the 63 province capitals equalled 63 per cent. In England in 1891 urban debt was 92 per cent; rural debt, 1.3 per cent; and debt of mixed (urban and rural) districts 6.7 per cent. In the United States in 1890 cities of over 4000 population had 85 per cent of the total municipal debt.

In the following table is shown the total and the per capita debt of some of the principal cities of the world:-

MUNICIPAL DEBTS, 1898-1899 1

\begin{tabular}{|c|c|c|c|c|c|}
\hline City & Amount & $\begin{array}{c}\text { Per } \\
\text { Capita }\end{array}$ & City & Amount & $\begin{array}{c}\text { Per } \\
\text { Capita }\end{array}$ \\
\hline Brussels . . & $\$ 56,000,000$ & $\$ 280$ & Glasgow. . & $\$ 43,000,000$ & $\$ 59$ \\
\hline Zürich (1891) . & & 230 & Liverpool . & $43,000,000$ & 90 \\
\hline Paris . . . & $443,000,000$ & 160 & Birmingham & $60,000,000$ & 86 \\
\hline Antwerp (1891) & & 155 & Lyons . . & $14,000,000$ & 32 \\
\hline Manchester. & $79,000,000$ & 150 & Marseilles . & $18,600,000$ & 42 \\
\hline Boston . & $59,000,000$ & 105 & Bordeaux . & $6,000,000$ & 24 \\
\hline Cincinnati . & $27,263,313$ & 83 & Lille . . . & $6,400,000$ & 30 \\
\hline New York . & $251,632,705$ & 73 & Havre . & $6,600,000$ & 55 \\
\hline London . . & $243,206,515$ & 54 & Rouen . . & $8,200,000$ & 74 \\
\hline Berlin . . & $66,219,175$ & 37 & Amsterdam & $40,000,000$ & 80 \\
\hline Munich . & $25,000,000$ & 55 & Rome . . & & 80 \\
\hline Leipzig . . & $17,500,000$ & 40 & Milan . & & 54 \\
\hline Dresden . & $10,700,000$ & 27 & Chicago . . & $29,163,723$ & 17 \\
\hline Breslau . . & $13,000,000$ & 32 & Philadelphia & $41,211,030$ & 32 \\
\hline Cologne . & $10,000,000$ & 29 & St. Louis . & $19,105,594$ & 33 \\
\hline Frankfort & $17,700,000$ & 68 & Baltimore . & $32,928,106$ & 64 \\
\hline Hanover. & $16,000,000$ & 68 & Cleveland . & $12,233,020$ & 32 \\
\hline
\end{tabular}

1 Cadoux, Les Finances de Paris. Statistisches Jahrbuch Deutscher Städte, VIII. Paul-Dubois, Essai sur les finances communales. 
The amount of the debts of the large cities is a necessary result of the vast expenditure made during the last half century for public works, and in the case of many of the older cities for the almost complete reconstruction of large parts of the cities; and it is at the same time a significant indication of the size of the outlay for such purposes. It is not possible to deny the value and importance of this expenditure, nor to shirk the duty of providing for the health and safety of the community in accordance with modern scientific knowledge and engineering skill. It is therefore unreasonable to class municipal debt incurred for these works as a necessary proof of extravagance and financial mismanagement. At the same time, however, it must also be recognized that the enormous development of municipal debt constitutes one of the serious problems of municipal finance, and that there is always the danger that loans may be incurred for expenditures properly chargeable to current funds, or more freely than the resources of the community warrant. However important the public works of the modern movement, it is equally essential that the expenditure be limited by the available assets of the community. The danger of excessive debt is most serious in the smallest cities. The largest cities, while they have the largest debts, have also the largest resources, and also the best-developed financial administration. The cities of moderate size, however, which attempt to equal the works of the metropolis without its available sources of revenue, are very likely to find themselves in serious difficulties. In the 70's many towns in the United States bonded themselves so heavily for railroad aid that repudiation was resorted to, and even the considerable city of Elizabeth, N.J., was forced to bankruptcy by its extravagant construction of street works.

In the various countries of Europe the loans of the municipalities are generally subject to the control of the higher authorities. This control is exercised in France by the prefects; in Prussia by the bezirk presidents and province governors; in England by the Local Government Board. In the United States there is no systematic supervision, but 
instead in many cases there are constitutional or legislative provisions limiting the total amount of debt to a certain per cent of the assessed valuation of property. These limitations run all the way from 2 per cent (as in Boston and Detroit) to 10 per cent (as in New York and Louisville); while in Los Angeles, Cal., the limit is 15 per cent, and for a number of cities there are no limits established (for example, Baltimore, Cincinnati, Newark, Jersey City, and St. Paul). The wide differences caused by variations in the limits are added to by the varying bases of valuation; and there is no system of adjusting the amount of the debt to the real financial resources of the city. Sometimes debt incurred for waterworks is exempted from the limit, as a self-sustaining undertaking. 


\section{CHAPTER XV}

\section{Municipal Revenues}

There are three main categories of municipal receipts : 1 , commercial receipts from public property and public services; 2, subventions or grants from the government ; and 3 , fiscal receipts from various systems of local taxation. The last is everywhere the most important, but a few words must be said as to the other two.

\section{COMMERCIAL REVENUE}

The original, and until the modern urban movement the principal, source of municipal revenue was from the domain lands, which the towns retained as public property after the partition of the mediæval common fields to individual holders. The origin of these communal lands goes back to the beginnings of the mediæval town system; but we need only note the fact that after the system of common ownership had given way to individual properties, there remained considerable tracts of land belonging to the community collectively, and subject to common use for pasturage, wood, and the like. During the nineteenth century, however, throughout Europe these common lands have been used as sources of revenue. In Central and Western Europe they have been largely sold outright and a considerable part of the income has vanished; but in Russia and Austria the communal domain continues to be a considerable and important source of revenue, which in some backward towns yields from 30 to 40 per cent of the total. Vienna derives $\$ 1,500,000$ a year from her common lands. 
In Prussia the communes receive but 14 per cent of their revenues from this source; in France, 11 per cent; in Italy, 10 per cent; and in Belgium, 9 per cent. ${ }^{1}$ In Great Britain this source of income is of still less significance. Many of the large cities are of such recent development that they have no ancient property, while others have generally disposed of their former estates. The city of London has, however, a revenue of $\$ 900,000$ a year from rentals; Liverpool, $\$ 800,000$; Newcastle and Doncaster, over $\$ 100,000$ each - the last, a town of 25,000 , has been able on account of this revenue to dispense with the usual borough rate. ${ }^{2}$ Glasgow has an income from real property of $\$ 270,000$, and Birmingham, $\$ 300,000$, part of which is from property secured in connection with improvement schemes during the last thirty years. In the United States municipal lands are now almost unknown. New York and Albany, by their colonial charters, owned large tracts of land, but these have long since been sold.

Similar in character to these public lands may be mentioned the modern investments of sinking funds in all cities, to provide for the redemption of loans. These are, however, temporary investments, and the income is not used for the active work of the city.

The revenue from municipal franchises is also of the same general nature as receipts from municipal property. These are payments from various companies, notably street railway corporations and gas companies, for the privilege of using the public streets.. These are based on contracts between the companies and the municipal authorities, and should be distinguished from charges based on the exercise of the power of taxation. Such contracts, too, usually have stipulations as to the rates to be charged and the services to be furnished by the companies, as well as the payments to the city; and such stipulations in the interest of the general public may be preferred to larger payments into the

1 Paul-Dubois, Essai sur les finances communales, p. 142.

2 But this does not mean exemption from local taxation. The poor rate, and probably also the urban district rate, was levied. 
municipal treasury. In point of fact the stricter stipulations are generally found in conjunction with large contributions by the companies to the municipal revenue ; and strict contracts providing for both are the rule in British and German cities. In the United States the grants to such companies have been very loosely drawn, and only a very few cities receive any considerable income for franchise privileges. The American cities which receive the largest income of this kind are Chicago, with a franchise revenue of $\$ 416,474$ in 1899 ; Baltimore, with $\$ 283,049$; and Louisville, with $\$ 137,416$.

Another form of commercial revenue, which is by far the most important in the large urban communities, is that derived from certain public works and undertakings of the modern city, such as waterworks, gasworks, markets, docks, and wharves. These are especially prominent in the British and German cities, which have entered so largely on functions of this character. In these countries this revenue forms a very large share of the aggregate income of the important cities. In England and Wales, this revenue, for the year ended March 31, 1898, amounted to $£ 11,750,000$, out of a total ordinary income of $£ 69,000,000$, or one-sixth of the whole. In Berlin revenues of this sort amounted to $\$ 9,000,000,30$ per cent of the entire municipal income; in Paris $\$ 14,000,000,22$ per cent of the total; and in New York, $\$ 14,500,000,16$ per cent of the total. In most American cities revenue of this kind is almost insignificant. The census figures for 1890 show that the aggregate for cities of over 4000 population was only 2 per cent of the total ordinary income of these cities. The great bulk of this revenue goes to meet the special expenses of the undertakings from which it was derived; but in some cases there is a net profit, which is applied to lighten the burdens of local taxation. The following tables show the results in England and Wales for the five years ended March 31, 1898, with the latest figures for Germany and the United States : - 
COMMERCIAL UNDERTAKINGS : ENGLISH TOWNS - 1893-18981

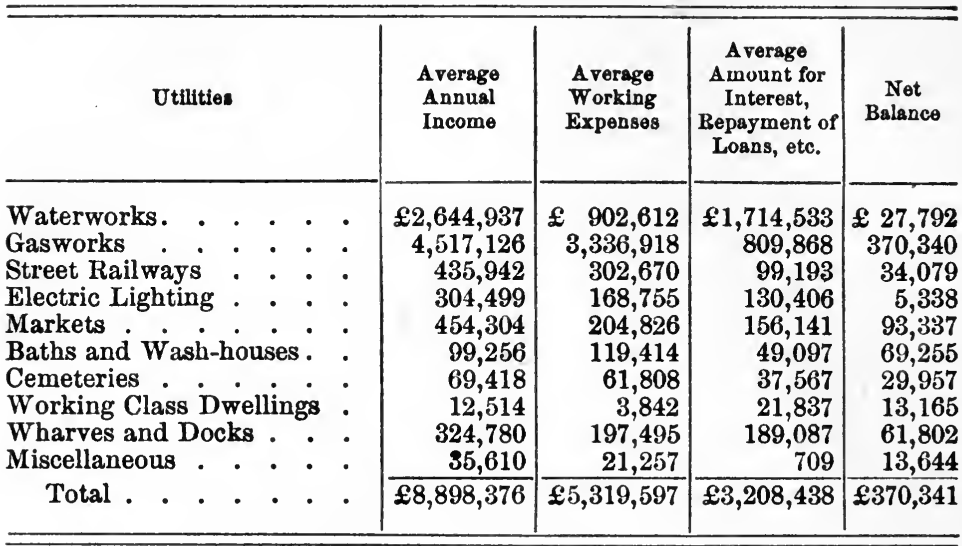

COMMERCIAL INCOME : GERMAN CITIES - 1897-1898 ²

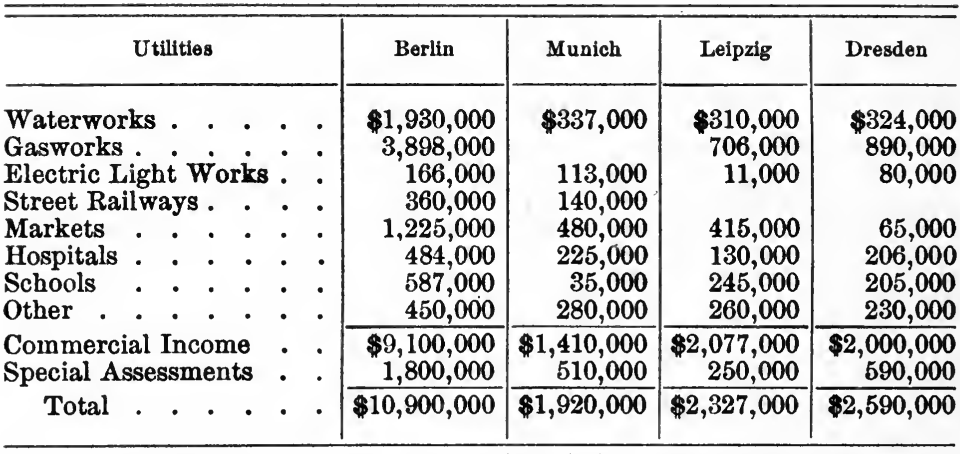

COMMERCIAL INCOME: UNITED STATES CITIES-1890

\begin{tabular}{|c|c|c|c|c|}
\hline Utilities & & $\begin{array}{c}\text { Cities over } \\
50,000\end{array}$ & $\begin{array}{c}\text { Cities } 4000 \text { to } \\
50,000\end{array}$ & Total \\
\hline $\begin{array}{l}\text { Waterworks, etc. } \\
\text { Special Assessments } \\
\text { Total Ordinary Income } \\
\text { State and County Taxes }\end{array}$ & 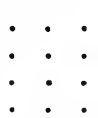 & $\begin{array}{r}\$ 4,270,006 \\
16,704,516 \\
186,916,541 \\
5,056,458\end{array}$ & $\begin{array}{r}956,706 \\
4,839,133 \\
64,694,911 \\
3,024,153\end{array}$ & $\begin{array}{r}5,226,712 \\
21,543,649 \\
251,611,452 \\
8,080,611\end{array}$ \\
\hline
\end{tabular}

1 Return to House of Commons, March 9, 1899, in Journal of Royal Statistical Society, Vol. 63, p. 407.

2 Statistisches Jahrbuch Deutscher Städte, VIII, 205. 


\section{SUBVENTIONS}

Government subventions form a source of municipal revenue almost unknown a half-century ago, but now a striking feature in the municipal budgets of the European cities. They may be divided into two classes : special subsidies and general grants - the former being for certain special purposes to which their use is limited, while the latter are a fixed share of certain revenues collected by the general government, which are available for the general purposes of the municipalities.

The special subsidies have arisen in connection with laws compelling the municipalities to perform certain functions of a general as well as of local interest, - such as education, poor relief, police, and main roads. State aid in these directions has been necessary to secure the desired local action, and the State grants have been subject to their use for the purposes named. These special subsidies had their origin in Great Britain in the "grants in aid," first authorized in $\mathbf{1 8 3 3}$ for the development of schools. Similar subsidies followed for the police, poor relief, and other lines of activity, until in 1888 the aggregate of these subsidies was over $\$ 24,000,000$. In 1888 fixed general grants were substituted for a large part of the special subsidies, although the latter remain for some purposes, such as schools and police. France also has developed an elaborate system of special subsidies, for which has been substituted in the case of primary education the direct assumption by the State of part of the expenses. In Prussia there are considerable grants to the municipal authorities. The local roads, formerly aided by the State, have since 1875 received subsidies from the provinces and circles. Under recent laws the State pays the salaries and pensions of teachers in the elementary schools. In Belgium both the State and the provinces give grants in aid of roads and elementary education. Less is done along this line in Italy than in any other country of Europe, the grants for elementary schools and roads amounting to less than $\$ 2,500,000$.

In the United States there are large grants by the state 
governments for the support of the common schools, and in New Jersey, Massachusetts, and New York, there are subsidies for roads. The aggregate of state funds given to the local school authorities for 1889 amounted to $\$ 32,812,483$, and the average for the ten years then ended was $\$ 26,649,509$. The states which gave the largest proportionate grants, with the amounts for 1889 , were: California, $\$ 2,655,089$; New Jersey, $\$ 2,307,314$; Massachusetts, $\$ 2,947,299$; and Indiana, $\$ 2,017,273$. Most of the states have school funds derived mainly from the sale of public lands, and some part of the school grants comes from the income of these funds. The greater part, however, comes from state taxation, and under the existing method of taxation the cities pay a larger share of the tax than they receive as school grants, so that the subsidies are a positive aid only to the rural districts.

The system of general grants is much less used than that of special subsidies, and they are of importance only in Great Britain and Belgium. In Belgium the general grants from national revenues were established in 1860 to compensate the communes for the loss of the octrois, or local customs duties, which were then abolished. A fund was established, to consist of 75 per cent of the customs duties on coffee, 35 per cent of the customs and 35 per cent of the excise on spirits, beers, and wines, and 41 per cent of the postal taxes - the revenue being distributed among all the communes in proportion to the amount of their local taxes. In 1889 another communal fund was provided, consisting of the revenue from new liquor saloons (debits), and the customs on cattle and meat. The communal receipts from these funds is about 30 per cent of their total ordinary receipts.

In Great Britain the system of general grants was estab. lished in 1888, replacing former special subsidies, by assign. ing to the local authorities the whole or part of the revenue from certain succession duties (inheritance taxes), license taxes, and four-tenths of the probate duties, to which was added in 1891 additional revenues from duties on beer and spirits. The income from these local taxation licenses is 
nearly stationary and does not tend to increase with the growth of local expenditure. The revenue from both classes of government grants in Great Britain is about $£ 11,000,000$, which is 15 per cent of the total ordinary local revenue, excluding loans.

\section{THE FISCAL SYSTEMS}

The most important source of municipal revenue in countries having a large urban population is the local taxes; and as these are based on different principles in the different countries, it is necessary to note the systems of the principal countries with some care.

\section{France}

There are three main divisions in the local taxation scheme in France : the centimes additionels, the octrois, and the special taxes. The centimes additionels, which date from the Revolution, are additions to the four direct State taxes on lands and buildings, personal property, doors and windows, and trades. When the State taxes are apportioned, each commune ascertains the rate (expressed in centimes) necessary to raise its share of the State revenues; and to this is added a sufficient additional rate (centimes additionels) to secure the revenue for the local purposes. The entire amount for both State and local purposes is collected together, and the commune receives for its own use the receipts from the centimes additionels. The octrois are duties levied at the city gates on articles of consumption - principally food supplies and drink. They appeared somewhat later than the centimes additionels, and have developed to a marked degree, especially in the larger cities. In 1823, 1434 communes had octrois, and 1501 in 1899 , but the increase in urban population in that period doubled the population subject to octrois. About half of the octrois revenue is from liquors, and of the liquor revenue, three-fourths comes from wines and beers; bread is always free, but there are taxes on meat, eggs, and fuel. Of the special revenues, the most important are those called presta- 
tions, which are of especial significance in the rural communes. They are levied on landowners and active capitalists, especially on those engaged in trades which make use of the roads. They are based on the number of men and carts employed, and are, in fact, a kind of special assessment for the construction and maintenance of the local roads. Special assessments are, however, but slightly used in the French cities; there are some such in Paris for street cleaning, and they are authorized for paving, but are very rarely resorted to. The other special revenues are the tax on dogs, and commercial income from the public domain, markets, abattoirs, and stands in the public ways.

As to the relative importance of these divisions of revenue, if Paris be excluded, each division furnishes roughly one-third of the total revenue. Including Paris, however, the aggregate income from octrois is nearly one-half of the total local taxes. If again the rural communes be excluded, the special revenues become of much less importance.

MUNICIPAL REVENUE: ALL FRANCE

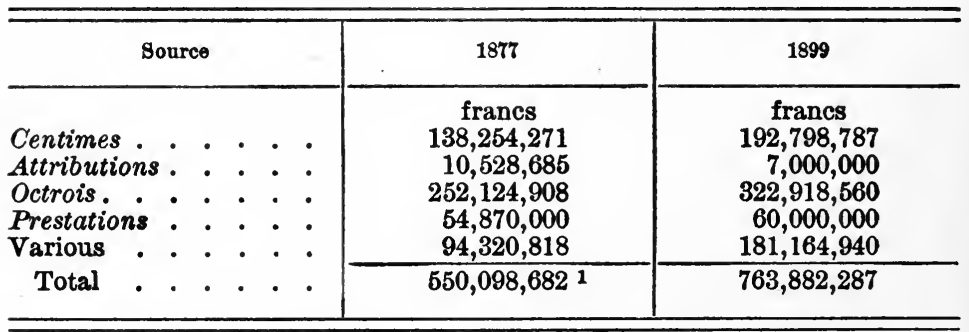

MUNICIPAL REVENUE : FRANCE, EXCLUDING PARIS

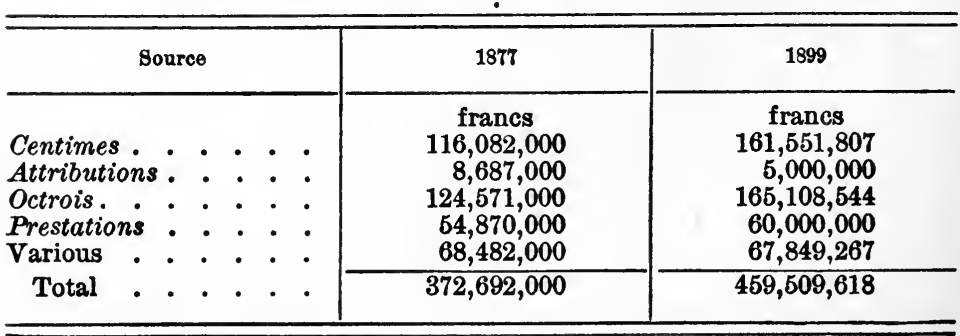

182 per cent of total local receipts. 
In the larger cities the octrois form the principal source of revenue, while the commercial income is also of increased importance. The following table shows the leading items of municipal revenue for Paris, Lyons, and Marseilles in 1898, and also the amount raised for the State and department treasuries :-

REVENUES OF FRENCH CITIES - $1898^{1}$

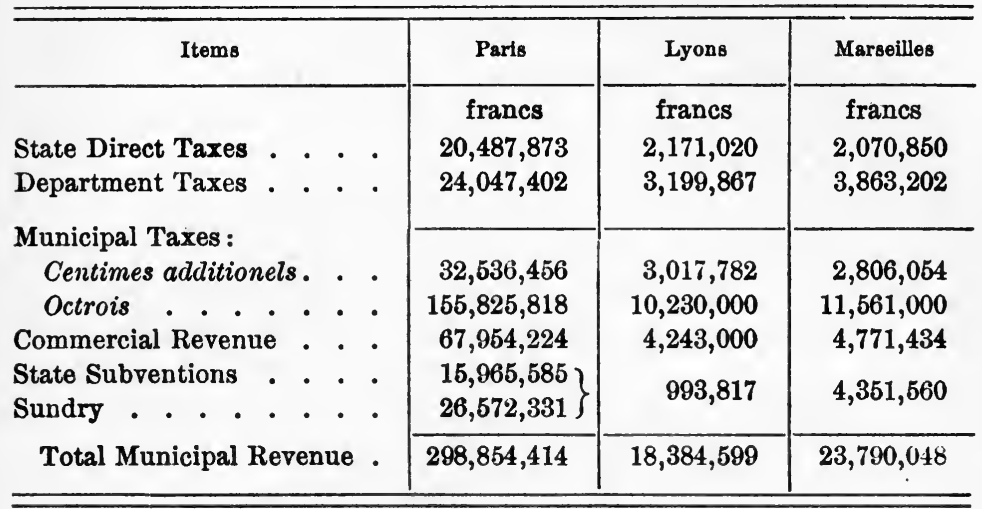

The octrois are the most burdensome of the French municipal taxes. They are, at the same time, the most expensive to collect, the cost of administration running from 10 per cent to as high as 20 per cent of the income. For these reasons there has been a strong agitation for the abolition of the octrois, and, in a few cases, this has been accomplished. At the beginning of 1901, some radical changes in the Paris system have taken place, involving a net reduction of $45,000,000$ francs in the octrois receipts. The duties on wine, beer, and other light beverages have been abolished. The rates on spirits and strong liquors have been somewhat increased, but the greater part of the revenue is made good by new taxes on rents, carriages, and a succession duty.

\section{Italy}

In Italy the main local taxes are similar to those in France : centimes additionels and octrois, with a grant from

1 G. Cadoux, Les Finances de la ville de Paris, 237, 682, 683, 695. 
the State (10 per cent of the tax on movable wealth) and a great variety of local special taxes. The State, however, allows the communes to add the local centimes only on the real estate and house valuations, and the concentration on this class of property, added to the unequal distribution of the national taxes, makes the burden a very serious one. The principal special taxes are those on family wealth, on rental value, and on agricultural animals. The first is used in 5000 communes out of the 8259 in the country, and the second in 700 ; but the revenue received is not of large amount. The principal source of local revenue is the octrois, or dazi di consumo, yielding 44 per cent of the communal taxes. The revenue from this source increased 69 per cent between 1875 and 1889, while the income from the centimes additionels increased but 18 per cent. The octrois, or dazi, are of most importance in the large cities, but they are to be found in 86 per cent of the communes (in 7163 out of the 8259 ). The communal octrois are, moreover, levied in addition to government octrois. There are, also, in Italy, communal license taxes on business houses and professions, and on inns and liquor shops, together with several other license taxes of less value. Special assessments are allowed, but are not frequently resorted to. The mass of different varieties of taxes, none of which yields much, while each involves an added expense for its collection and administration, produces much annoyance, and the difficulty of securing funds prevents the Italian cities from entering on many lines of activity.

MUNICIPAL TAXATION: ITALY $-1889^{1}$

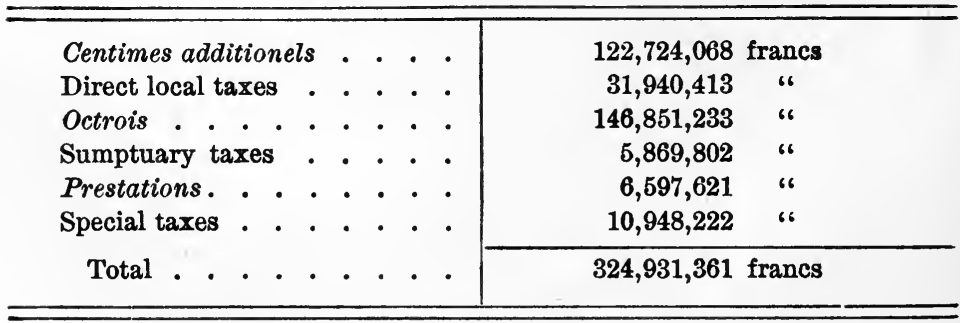

1 Paul-Dubois, Essai sur les finances communales, p. 177. 


\section{Belgium}

The local taxes in Belgian cities are a much less important part of the municipal revenue than in any other country, due in the main to the system of government grants in lieu of the former octrois duties. Only about 27 per cent of the ordinary receipts is from local taxes. Of this 27 per cent revenue, nearly half ( 47 per cent) is from centimes addition$e l s$, as in France, but the average rate is only 26 centimes, as compared with 46 centimes in France and 67 in Italy. The remaining revenue derived from direct local taxes comes from a variety of sources: personal taxes assessed on various principles, taxes on mines, factories, professions, and many others, no one of which is of marked importance. The system of prestations is used largely by the Belgian rural communes, as in France ; for example, there is a labor tax, or special assessment on landowners or proprietors of industries which damage roads. Furthermore, the Belgian cities apply the same principle (as the French cities do not) in the construction and maintenance of public works, such as streets, sidewalks, and sewers, which are paid for in part by special assessments on the owners of property adjacent to the improvement. Thus, in Brussels, the tax for improvements is doubled in new streets, and increased by one-half in streets which undergo enlargement.

\section{Germany}

There is no uniform system of municipal taxation in the German cities, partly on account of different systems of general taxation in the several states, but partly also on account of a larger freedom left to the localities, especially in Prussia. A law passed in $\mathbf{1 8 9 3}$ attempted to provide a more general system in Prussia, and particularly to limit the use of the income tax for municipal revenue. The State abolished its trade and property taxes, expecting such taxes to become the principal sources of municipal revenue ; but as municipal taxes then existing were allowed to remain, the characteristic diversity between different cities still continues. 
Considerable municipal revenue is now secured by taxes on property; and some by taxes on trades; but the most striking feature of the municipal taxes in Prussia (and the same is true of cities in other parts of Germany) is still the large share of revenue raised by the tax on incomes. Among the Prussian cities the income tax generally produces as much as 40 per cent of the total tax revenue; and in Saxony it is sometimes over 60 per cent. In Bavaria there is no general income tax, and the special income taxes yield a much smaller, though still noticeable, share of municipal revenue.

Taxes on consumption, corresponding to the French octrois, are also found in Germany. In Alsace-Lorraine these duties have equal importance with the octrois in French cities; and in the cities of Munich, Breslau, Dresden, Mainz, and Darmstadt, they furnish from 20 to 30 per cent of the revenue derived from taxation. Elsewhere taxes on consumption are generally of much less importance. At Berlin the octrois income is only 770,000 marks, or 1.5 per cent of the total tax revenue; at Leipzig they have been entirely abolished; at Cologne they yield 360,000 marks, or less than 5 per cent of the tax revenue; and at Frankfort, 88,000 marks, less than 1 per cent.

MUNICIPAL TAXATION : PRUSSIA ${ }^{1}$

(1169 cities)

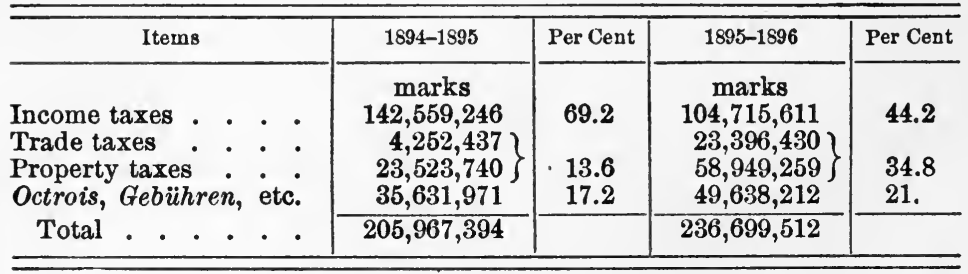

STATE TAXES: PRUSSIA

\begin{tabular}{|c|c|c|c|c|c|c|}
\hline $\begin{array}{l}\text { Ergänzungsteuer } \\
\text { Income taxes } \\
\text { Property taxes } \\
\text { Trade taxes } \\
\text { Indirect taxes. }\end{array}$ & 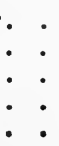 & & $\begin{array}{l}86,531,970 \\
80,416,968 \\
25,354,759 \\
71,603,252\end{array}$ & $\begin{array}{r}24.9 \\
23.1 \\
7.3 \\
20.6\end{array}$ & $\begin{array}{r}33,047,000 \\
122,752,154 \\
69,885,008\end{array}$ & $\begin{array}{l}10.2 \\
39.1\end{array}$ \\
\hline Total ${ }^{2}$. . & . & & $348,678,915$ & & $314,048,868$ & \\
\hline
\end{tabular}

1 Statistisches Handbuch für den Preussischen Staat, III.

2 Including other revenue received by the Ministry of Finance; but excluding the revenue from railroads, public works, and other departments. 
MUNICIPAL TAXATION : GERMAN CITIES - 1897-1898 1

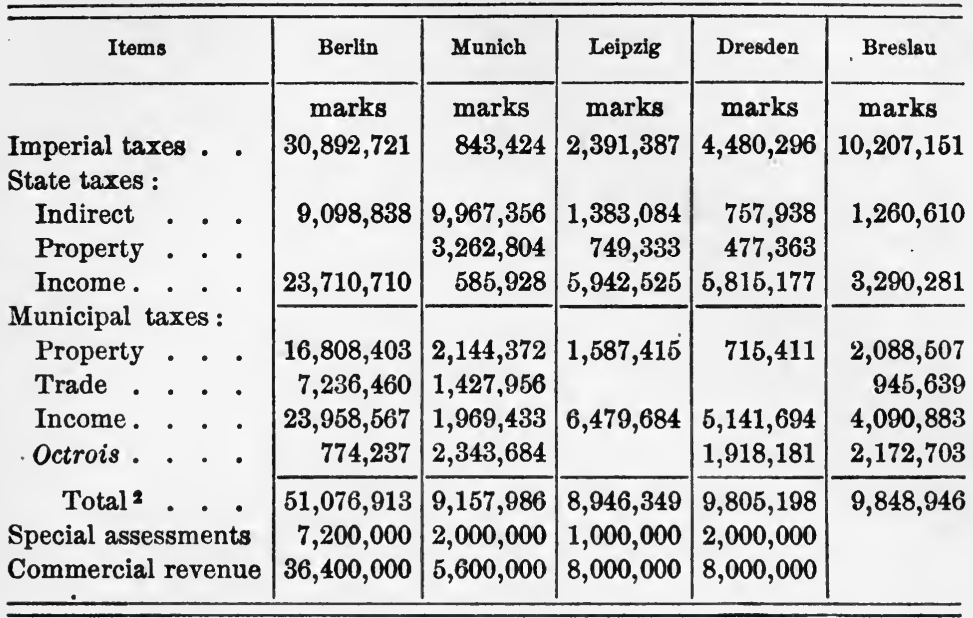

\section{England}

The English system of local taxation is radically different from that in the continental countries. In the first place, trade taxes and octrois may be said not to exist, and all of the local taxation is raised by assessments on real property, including in that term both lands and buildings. In the second place, the taxes so levied are assessed by an entirely different method from that employed in assessing property taxes in other countries, being based, not on the capital value of the property, but on the annual rental value. In the third place, these taxes on the rental value of property are entirely local, and wholly independent and distinct from the taxes levied for the national government. The differentiation is so marked that the local taxes are not called taxes, but rates, while the former term is limited in its application to taxation for the national exchequer.

While, however, there is but one system of local taxation, so far as the subject of taxation is concerned, the English

1 Statistisches Jahrbuch Deutscher Städte, VIII.

2 Including sundry minor taxes. 
system again differs from that on the continent of Europe in having a large variety of distinct levies made on this single basis, for different purposes of local government. To a large extent these different levies or rates are made by different local authorities, but there are also cases in which a single authority levies more than one rate. The study of English local taxation is thus a study of the various rates. As usual in English matters, this demands some historical discussion of the development of the existing system, which is all the more important for us because the early stages are steps in the development of the American system of taxation.

At present, the various local rates are all based on the poor rate, which was definitely established in the reign of Elizabeth. There were, of course, local taxes before that time; "scot" and "lot" were collected in the boroughs of the later Saxon and early Norman reigns ; and later came the firma burgi. Church rates have been traced back to $1189,{ }^{1}$ and were well established by the beginning of the fourteenth century. Sewer rates for drainage improvements were levied in money by the middle of the fourteenth century. ${ }^{2}$ Paving rates had begun by 1477 . During the fifteenth and sixteenth centuries other rates were authorized by special acts of Parliament.

The earliest methods of assessment seem to have been to determine in a rough and ready way the amount which each person had to pay; and while a man's property would be taken into account, apparently no systematic valuations were made. The early poor laws provided at first for voluntary alms ; later statutes authorized the assessment of those who refused to give voluntarily; but even in the act of 1572 , authorizing a systematic tax for poor relief, there were no rules in regard to the method of assessment. The statute of $\mathbf{1 5 9 7}$ provided for the taxation "of every inhabitant and every occupier of lands"; and in 1633 it was definitely decided

1 C. H. Blunden, Local Taxation and Finance, p. 2.

2 Edwin Cannan, History of Local Rates in England, p. 12. 
that a non-resident should not be assessed for the poor rate in respect to rents for lands in the parish, the occupier of which was assessed. Under the Commonwealth there is evidence of a general adoption of rents as the basis of assessment. Whether or not movable property should be included in addition to rental value was not definitely decided until 1840. In most places there seems to have been little or no assessment in respect to movable property ; but in the older manufacturing districts, stock in trade of business houses was assessed in some parishes. A decision of the Court of Queen's Bench in 1840 led to a circular letter of the Poor Law Commissioners ordering stock in trade to be assessed everywhere ; but this action led to the prompt passage of a statute forbidding this. Thus the rates at present are confined to the rental value of lands and buildings.

Local taxes existing before the poor rate have either disappeared, or have become merged in some of the later rates, while these latter have been imposed as additions to the poor rate, based on the poor rate assessment. Highway rates on this basis were first authorized by statute in 1691. In the first part of the nineteenth century several minor rates were established, which have been merged in the county rate. The borough rate and borough watch rate were established in 1835. Special rates for local improvements in particular communities had also been authorized from time to time; and the Public Health Act of 1848 empowered any urban district to levy a general district rate for the purposes authorized in the statute. In 1870 the school rate was established. in connection with the elementary school system inaugurated at that time.

Of the variety of rates now in use, many are not only based on the poor rate, but are assessed and collected with the poor rate, under the term of precept rates. Thus the county rate, the borough rate, the school board rate, the burial board rate, and the rural sanitary rate are usually levied as precept rates. By far the most important rate collected independently of the poor rate is the general district rate, levied by the urban district authorities, for sanitary and other urban 
improvements. There also appears a "private improvement rate," which is not a general tax, but a special assessment for such improvements as water supply, drainage, and paving, in a newly built district, levied only on the property directly benefited.

In determining the valuations for the local rates in England, there is first determined the "gross estimated rental," based on the yearly rent a tenant would pay, who was required to pay the tithes and the usual tenant's taxes. From this a deduction is made to cover the average expense for repairs, insurance, and renewals; and the balance is the "ratable value." In the case of railways, gasworks, mines, and other monopolies, the valuation includes the enhanced value due to the monopoly character. With the total ratable value for a given parish, and the amount to be raised by rates, the amount of tax for each pound of ratable value is readily determined; and this is known as the rate. In large cities this varies from five to eight shillings in the pound. Rates for certain purposes are levied only on a fractional value. Watching and lighting rates when levied in respect to lands and tithes are chargeable only on one-third of the full rate; sanitary rates in urban districts in respect to agricultural lands, tithes, railways, docks, and canals, are chargeable on one-fourth of the ratable value. In other respects the assessment system is inadequate. Except in the metropolis, no statutory provision requires a periodic revaluation of properties, and there is no uniformity in the scales of deductions from the gross rentals. Outside of London, the aggregate rental value for local rates is nuch smaller than the value determined by the officials of the national government for the income tax assessments. Lands not yielding rent are exempt from local rates. Moreover, the imposition of the tax directly on the occupiers imposes a large burden on the laboring and artisan classes, who must spend a large share of their income on house-rent.

The proportions of the total annual value of rated property in the several principal classes, in certain years from 1814 to $1890-1891$, were as follows :- 


\begin{tabular}{|c|c|c|c|c|c|}
\hline Items & & 1814 & 1843 & 1868 & $1890-1891$ \\
\hline Lands and tithes & . & $69.28 \%$ & $49.10 \%$ & $33.20 \%$ & $19.24 \%$ \\
\hline Houses. . . & - & 27.84 & 41.44 & 47.27 & 56.35 \\
\hline Railways . . & & & 2.82 & 11.11 & 14.02 \\
\hline Other property & . & 2.88 & 6.64 & 8.42 & 10.39 \\
\hline
\end{tabular}

These local rates yield about 60 per cent of the total revenue of the English local authorities. As has been noted, the government subventions amount to 15 per cent, and the income from rents and industrial enterprises to 18 per cent. There is also a small proportion received from tolls, dues, fees, fines, and licenses.

\section{CLASSIFIED RECEIPTS OF LOCAL AUTHORITIES IN ENGLAND AND WALES}

(Exclusive of loans)

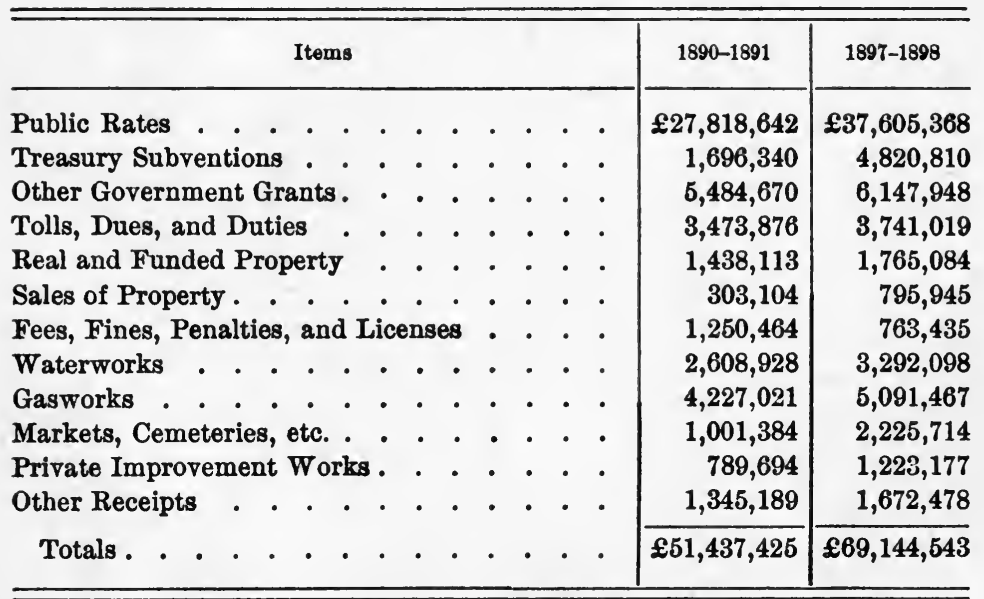

\section{United States}

In the United States the most general form of municipal taxation is the general property tax, which is an evolution from the English poor rate. The main differences 
between the two are that in America the attempt is made to reach personal property as well as real estate, and that the assessment is made on a capital valuation and not on rental. The full details of the process by which this differentiation occurred are not clear; but the evidence shows that even before the end of the seventeenth century the main features of the present system were in operation in America. In the Massachusetts tax law of 1634 we find the same vague terminology as in the English statutes of that time. "In all rates and public charges the town (through their assessors) shall have respect to levy every man according to his estate, and with consideration of all other his abilities whatsoever, and not according to the number of his persons." Sixty years later, another Massachusetts tax law prescribes methods of assessment that are almost identical with the present system. The act of 1697 provides for the preparation of a tax list, to show "What each particular person is to pay against his or her income respectively; the first column to contain the number of polls for which such person is assessed, and the sum set upon each of them, - the second column to contain the housing, land, or other real estate, for which such person is assessed, and the sum set thereupon, and the third column to contain the sum set by them upon such person for his or her personal estate and faculty."

A more detailed account of the method of assessment of local taxes is found in the Duke of York's Laws, which were enacted for the province of New York in 1665, and afterward were extended to the other Middle colonies.

"The lands and estates of all men wherever they dwell be rated for all Toune charges, both civil and ecclesiastical, where the lands and estates shall lie, and their persons where they dwell."

"The overseers . . . shall make a list of all male persons in the town of sixteen years old and upwards, and a true estimation of all personal and Real estates, being or reputed to bee the estates of all and every person . . . lands of all sorts, . . mills, ships, and all small vessels, merchantable goods, 
cranes, wharves, and all sorts of cattle, and all other known estate whatsoever."

Here follows a table of rates at which different kinds of animals are to be listed.

"Every one shall pay their rate to the constable of the Toune where he shall be assesed, nor shall any land or estate be rated in any other toun, but where the same shall lie."

We see in these provisions the differentiation from the present system of English rates fully accomplished. Assessments are made not on rental, but on capital value, and personal property is also included. An explanation for these differences may be suggested in the different conditions of land-holding in America and England. In England tenant farming was prevalent, and the rents were a tangible fact which expressed the value of the estate. In America there were few rents in proportion to the value of the estate, and the capital value, which could be ascertained roughly by actual sales, was the simplest measure of value. When the assessment came to be based on capital instead of rental value, it was natural to include the value of personalty, since that, too, could be readily ascertained under the rural conditions of the time. Nor was this altogether a novel feature, for in assessments based on the vague notion of "ability," some consideration must have been given to personal property holdings.

Another distinguishing feature of the American property tax which appeared early was its use for raising revenue for the central government of the colony as well as for local purposes. This was done in Massachusetts as early as 1634, and in New York in 1683.

While the machinery of the property tax was thus early developed, the amount of revenue raised by it, either for local or general purposes, was not of great importance during the colonial period, or even before the middle of the nineteenth century. As late as 1848 the total state and local taxes in New York were only $\$ 4,647,461$. But the large development of expenditures after 1850 was met to a great extent by means of the general property tax, which multiplied itself rapidly, 
and soon became the dominant and, for a time, the only important form of direct taxation in the United States. In this rapid development under new economic conditions there arose many serious evils in the application of the tax. The use of what was originally a local tax for raising a considerable amount of state revenue tempted the local assessors to undervalue property so that their district might bear a smaller portion of the state tax; and, in spite of state boards of equalization, this inequality still continues, and probably must continue under any system of local assessment. More significant were the evils in connection with the assessment of personal property. New forms of personal property could not be so readily assessed as the chattels of an agricultural community, and in the cities the personalty assessments have taxed only a small fraction of the personalty. The principle of the property tax also required double taxation in the case of mortgaged property and property held by corporations, while in the case of railroads and other corporations operating over an extensive area, the system of local assessment made impossible any adequate valuations of the property as a whole.

The following statistics will illustrate some of these points : -

AD VALOREM TAXATION IN THE UNITED STATES

\begin{tabular}{|c|c|c|c|c|c|}
\hline \multirow{2}{*}{ Year } & \multirow{2}{*}{$\begin{array}{c}\text { Ad valorem } \\
\text { Taxation }\end{array}$} & \multicolumn{3}{|c|}{ Assessed Valuation } & \multirow{2}{*}{$\begin{array}{l}\text { Estimated Tan- } \\
\text { gible Wealth }\end{array}$} \\
\hline & & Realty & Personalty & Total & \\
\hline 1850 & $\$$ & $\begin{array}{c}\$ \\
3,889,226,347\end{array}$ & $\begin{array}{c}\$ \\
2,125,440,562\end{array}$ & $\begin{array}{c}\$ \\
6,024,666,909\end{array}$ & $\begin{array}{c}\$ \\
7,135,780,228\end{array}$ \\
\hline 1860 & $94,186,746$ & $6,973,006,049$ & $5,111,553,956$ & $12,084,560,005$ & $16,159,616,068$ \\
\hline 1870 & $280,591,521$ & $9,914,780,825$ & $4,264,205,907$ & $14,178,986,732$ & $30,068,518,507$ \\
\hline 1880 & $313,921,474$ & $13,032,106,450$ & $4,107,797,045$ & $17,139,903,495$ & $43,642,000,000$ \\
\hline 1890 & $471,365,140$ & $18,956,556,675$ & $6,516,616,743$ & $25,473,173,418$ & $65,037,091,197$ \\
\hline
\end{tabular}

To obviate these evils, there have been established in many states one or more special taxes, notably taxes on corporations and on inheritances. These are state taxes, and are not directly connected with local taxation, but they offset partially 
the inequalities of the general property tax. It is strongly urged by the special students of the general problems of taxation that it would be well if the state should derive all of its revenue from such special taxes, and restore the property tax to its original position as a local tax; while in that case the cities might abandon entirely the taxation of urban personalty, as adequately reached by the various state taxes. In $\mathrm{New}$ York State the franchise tax law of $\mathbf{1 8 9 9}$ has made important changes in the assessments on street railways, gas companies, and other persons and companies using the public streets. Heretofore the franchise or privilege of using the public streets had been assessed as personal property, and, as such, deductions were allowed for bonded and other indebtedness, which resulted in the companies paying taxes only on their real estate. The act of 1899 provides that the value of the franchise - including the value of tangible property in any street or public place - shall be assessed as real estate (hence subject to no deduction for debts). It seems to the writer that this method is better than that proposed elsewhere of valuing first the physical property as detached units, and then estimating the value of the franchise as non-physical property. The Supreme Court of the United States has upheld this principle of a collective value which may far exceed the sum of the values of the particular detached pieces of property. To separate the monopoly franchise value from the value of the detached properties confuses the discussion and makes it appear that something intangible or non-existent is being taxed, while it also adds enormously to the problem of assessment by necessitating an examination of all the physical elements. A single valuation on the property as a whole (based probably on net earnings) not only simplifies enormously the work of assessment, but also makes clear that the "monopoly value" resides in the physical property, and not in any intangible elements.

Trade or business taxes are also to be found in the United States as a noticeable source of municipal revenue, though they are much less important than in Prussia. In most American cities the only important trade tax is that from 
retail liquor stores; but these taxes are placed so high for police purposes that they yield not a little income. In New York the tax is $\$ 800$ a year on each retail dealer; in Minnesota, Nebraska, and Missouri, from $\$ 500$ to $\$ 1000$ - the larger amount in the cities; in Massachusetts, $\$ 1300$; in Pennsylvania, $\$ 500$, and in several Southern states from $\$ 500$ upwards. Illinois imposes a tax of $\$ 150$ on saloons dispensing only malt liquors, and $\$ 500$ on saloons selling all liquors.

In many states a part of the revenue from liquor licenses goes to the county, and in some states part to the state treasury. Thus in New York the cities receive two-thirds and the state one-third; and in Massachusetts the cities receive three-fourths and the state one-fourth. Municipal revenue from liquor licenses in 1890 in cities of over 4000 population was $\$ 14,442,448$, while the total revenue from liquor licenses was $\$ 24,786,496$. In 1899 New York city alone received $\$ 5,713,869$ from this source; Chicago, $\$ 3,127,403$; Philadelphia, $\$ 1,709,134$; St. Louis, $\$ 974,071$; and Boston, $\$ 1,482,077$.

There are various other license and trade taxes in American cities, but only in some Southern cities are such taxes at all general on all kinds of business, and only there do they yield any considerable revenue. In the United States the total revenue from trade taxes other than liquor licenses is less than one-half that from liquor licenses alone. In Atlanta these other trade taxes amounted in 1899 to $\$ 114,073$, almost one-third more than the liquor licenses, and nearly one-sixth of the property tax. In Savannah (Ga.) the other business taxes produced $\$ 100,971$, more than double the liquor licenses and one-fifth of the property tax revenue. In Norfolk (Va.) the income from the other trade taxes $(\$ 109,029)$ was three times that from liquor licenses and nearly one-sixth of the property tax. In New Orleans the revenue from this source $(\$ 182,000)$ is more than that from liquor licenses; and in Louisville it is about the same $(\$ 132,000)$ from each source; but in both of these cities the revenue derived from licenses on business houses is an unimportant share of the total income. 
A small revenue is also received from judicial fines in the police and municipal courts, but this is nowhere an important item.

Special Assessments. - The use of special assessments levied on the basis of direct benefits supposed to be derived from a given improvement, and not on the basis of ability or of the value of the property taxed, is a much more general factor in American municipal finance than in other countries. In part this difference is due to a real difference in the method of distributing the expense of such improvements ; but in part the difference is explained by the fact that in other countries a considerable share of such improvements is carried out directly by the property owners, which in America is done under municipal authority.

Although the system of special assessments is now but little used in England, and its use at all is bitterly opposed there, the American system was derived from England. The idea has been a prominent factor in public charges ; and specifcally it appears in the early English sewer rates (1427). But the system of assessment for the early drainage improvements was in fact based on the amount of property, and the sewer rate developed into a tax similar to the poor rate. The more obvious precursor of the American system is found in a statute of 1662 authorizing certain street improvements of Westminster, and providing for assessments on the property in consideration of the improvement made. Five years later another law for the rebuilding of London after the great fire contains an almost verbal repetition of the former law, with a more definite statement authorizing a tax "upon all houses within the said city in proportion to the benefit they shall receive." These acts have been specially referred to here because they seem to have been the model for the first law providing for special assessments in America. A New York province law of 1691 in its effective clause follows the English law of 1667 almost word for word. ${ }^{1}$

1 E. R. A. Seligman, Essays in Taxation, 341-343. 
In England the special assessment system fell into disuse, and has only recently been revived. In America, too, although the New York law remained in force, the system was but little used during the colonial period, nor, indeed, until after 1812. Since then special assessments have come into frequent use in American municipalities as a means of distributing the expense of improvements, although it was not until after the close of the Civil War that the system became general. In 1890 the receipts from special assessments in the United States aggregated $\$ 21,451,969$, equal to 5 per cent of the total revenue from the direct property tax, and a much larger proportion of the municipal revenue from such tax. Special assessments are used principally for street grading and paving, and for sewer construction, but also to some extent for parks and boulevards, where part of the expenses may be charged to the owners of adjacent property.

RECEIPTS OF UNITED STATES CITIES -1890

\begin{tabular}{|c|c|c|c|}
\hline \multirow{2}{*}{\multicolumn{2}{|c|}{ Items }} & \multicolumn{2}{|c|}{ Cities with Population } \\
\hline & & Over 50,000 & 4,000 to 50,000 \\
\hline \multicolumn{2}{|c|}{ Ad Valorem Taxes, Municipal Purposes } & $\$ 133,141,209$ & $\$ 45,151,711$ \\
\hline Licenses, Liquor . . . . & . . . . & $10,804,577$ & $3,637,871$ \\
\hline Licenses, Other . . . . & • • . & $4,064,329$ & $2,079,752$ \\
\hline Special Assessments . . & . & $17,004,516$ & $3,839,133$ \\
\hline Fees, Fines, and Penalties & . $\cdot$ & $2,018,401$ & 987,258 \\
\hline State and County Grants . & . & $5,056,458$ & $3,024,153$ \\
\hline Waterworks, etc., net . . & - & $4,270,006$ & 956,706 \\
\hline Deposits, Funds, etc. . & - & $4,140,768$ & $1,074,410$ \\
\hline Miscellaneoụs. . . . . & - & $6,416,277$ & $3,943,917$ \\
\hline Total Ordinary Revenue & . . & $\$ 186,916,541$ & $\$ 64,694,911$ \\
\hline
\end{tabular}




\section{CHAPTER XVI}

\section{Finance Administration}

HAVING examined the principal factors in municipal expenditure and municipal income, we can now consider the duties of the principal officials specially charged with financial administration. There are three main divisions in this field : the formation of the budget, by which receipts and expenditures are adjusted; the assessment and collection of revenues; and the systems of auditing and controlling disbursements.

\section{United States}

Budget Procedure. - The budget arrangements in American cities offer a wide variety, which it is impossible to reduce to any general statement. One distinguishing feature of the American arrangements is that the budgets are prepared by local officials subject to no administrative control, although there are legislative statutes regulating and restricting the total amount of municipal debt that may be incurred, special statutes making certain items of expenditure compulsory in particular cities, and in some cases statutes restricting the amount of the total tax levy. Of the variety of local budget methods, two contrasting systems may be described: the council system, which was formerly universal; and the board of estimate plan.

In the original council system the various spending departments submit to the council estimates of the amount needed or wanted for the following year. These estimates are considered either by a single appropriation committee, or by several committees; and an appropriation bill is prepared, discussed by the council, and passed subject to the mayor's 
limited veto power. The final bill will usually vary widely from the department estimates, and the responsibility for the accepted budget rests with the appropriation committees or the council as a whole. This system has in many cities tended toward extravagance, since the members of the council have been more interested in securing improvements than in reducing taxation; and it is on this account that there has been introduced in most of the large cities a board of estimate, or similar authority, with more or less power over the preparation of the budget. The powers of this board are most extensive in New York city. The board there has consisted of the mayor, the comptroller, the president of the department of taxes and assessments, the corporation counsel, and the president of the council - all but one administrative officials, but officials not connected with any of the large spending departments. The mayor, comptroller, and president of the council were each elected by popular vote; the other two officials were appointed by the mayor, so that the latter and his appointees could control the board. In 1902 a new organization goes into effect. The presidents of the five boroughs into which New York is divided are admitted to the board; and the various members are given different voting strength. The elected members will control the board; but the borough presidents will be officers directly interested in expenditures on public works.

To this board each department submits its estimates with comparative figures for the preceding year. Each department estimate is considered by the board after consultation with the head of the department, and the budget of expenditures is drawn up by the board and submitted to the municipal assembly. The assembly, under the charter of 1897, has no authority to increase any item in the budget, but may by a three-quarters vote decrease the amounts fixed by the board of assessment. Finally, the mayor may veto any item in an appropriation bill, and this veto can be overruled only by a five-sixths vote of all the members of each house.

The total regular appropriations for the year being determined in one way or another, the process of determining the 
tax rate is comparatively simple. To the appropriations are added the amounts prescribed for interest on loans, for sinking funds, and for state and county taxes. From the total is deducted the estimates of revenue from property, franchises, industrial undertakings, licenses, fees, and state grants. The balance is compared with the assessed valuation of taxable property for the city as determined by the assessors, and the rate necessary to yield the desired revenue is calculated.

Assessment and Collection. - The assessors have two functions to perform: the valuation of the property; and the 'assessment of the tax to each property owner at the determined rate. The valuations of property are commonly supposed to be made each year; but in large cities it is impossible for assessors to visit and inspect even all the real estate every year, and valuations usually stand for several years unless there is some marked improvement. Personalty assessments are made largely by guesswork. The general rule of law is that personalty must be assessed at the domicile of the owner; but some forms of tangible personalty may be assessed at its situs, and the confusion of the law on this point gives rise to double assessments. Moreover, owners of personalty are allowed to "swear off" their assessments in bulk in many states. There is, however, very little opportunity for judicial review of the individual assessments.

The valuations and tax assessments being made, the tax books are handed to the collector or receiver of taxes, who receives the payments from the taxpayers and turns the revenue over to the city treasurer. The amount received varies considerably from the total amount of the assessment. Small rebates are usually allowed for prompt payment, interest is charged on delayed payments, while there is always a number of delinquent taxpayers, whose taxes must be collected by special processes.

Accounting and Auditing. - The financial bookkeeping and auditing of accounts in all important American cities is carried out under the direction of a comptroller, auditor, or 
controller, who is, in most cases, an elective officer. In Cleveland, Chicago, and Detroit, however, the official whose functions correspond to those of the comptroller is appointed by the mayor. The duties of the comptroller in most cases include other functions than that of auditing accounts. Generally he has some supervision over the entire financial administration, while in cities where the board of estimate system has been adopted he has a large influence over the budget. In New York the comptroller is the head of the finance department, and the chamberlain (treasurer) is simply the chief of a bureau in that department; more generally, however, the treasurer is a coördinate official to the comptroller.

As auditing authority the comptroller's office examines and approves (or disapproves) all claims against the city; and payments are made by the treasurer only on warrants of the comptroller. This auditing system is in addition to the preliminary examination and approval of bills by the department concerned. In addition to the checking of accounts, the comptroller's bureau often does a large amount of inspection of work and supplies. On the other hand the comptroller's audit and inspection does not always include the whole field of municipal expenditure. School boards very often have an independent audit, and in some cases police and other boards conduct the audit of their own accounts.

The methods of keeping accounts in the different cities show the extreme of variety, and the total lack of anything like a general system. To a certain extent local differences require variations in the methods of municipal bookkeeping, especially for certain special and trust funds. But in America the variations go far beyond those made necessary. This lack of uniformity in accounting is one of the most serious obstacles in the way of a comparative study of municipal finances ; while in most cases the reports of municipal comptrollers are in such a confused condition that even one well acquainted with the local conditions finds it difficult, if not impossible, to understand the financial situation. In the Statistics of Cities prepared by the Department of Labor, an 
attempt is made to present the most important items for the cities of over 30,000 population. The figures given are determined after investigations by the agents of the department in the comptrollers' books, and are presented in a much more intelligible fashion than in most municipal reports; but with the limited means at their disposal, and the fundamental absence of any general system in keeping accounts, there must remain considerable doubt as to the accuracy of the comparisons.

\section{France}

Budget Procedure. - In the French cities and communes, the first step in the adoption of the budget is the preparation of a provisional budget by the maire, which is presumably in the larger cities based on estimates from the administrative bureaus. There is in the law a provision that if the maire does not act in this matter, the prefect of the department may prepare the provisional budget through a special delegate. This provisional budget is presented to the municipal council in the early summer, with the accounts for the preceding year. It is then discussed in detail at the annual session of the council (usually in May), which may last for six weeks; and after discussion the budget is voted by the council. Before the budget goes into effect, however, it must be approved by the higher administrative authorities: by the prefect of the department in most cases, but for those cities whose ordinary revenue is $3,000,000$ francs a year, by the President of the Republic on the proposition of the minister of the interior. There are now eleven cities in the latter group: Paris, Lyons, Marseilles, Bordeaux, Lille, Toulouse, St.-Étienne, Nantes, Le Havre, Rouen, and Roubaix. For this administrative examination and approval, the budget as voted by the council is transmitted by the mayor to the sub-prefect, accompanied by the accounts for the preceding year, the definitive budget for the current year, the report of the mayor to the council, the discussions in the council, and detailed statements in reference to each item in the budget. The various documents are forwarded to the prefect, with the 
advice of the sub-prefect. In the case of the eleven largest cities, the documents must again be forwarded to the minister of the interior with the observations of the prefect.

The administrative control over the budget is for the purpose of correcting errors in the estimates of revenues, and to assure the execution of laws and administrative regulations in reference to expenditures. In the matter of revenues, the prefect or president may increase or decrease the estimates for particular items, and add sources of revenue which have been omitted. In the matter of expenses, the higher authority may reduce any item, subject to two important exceptions : when all the obligatory expenses have been provided for and there are no extraordinary receipts, no reductions can be made; and the allowance for unforeseen expenses may be reduced or rejected only if the ordinary revenues, after satisfying all obligatory expenses, do not leave a sufficient surplus. The higher authority cannot increase the optional expenditures nor add any new item of that nature, but has power to insure adequate provision for all the obligatory expenses, subject, however, to elaborate regulations, to maintain the rights of the communes. Additions for such obligatory expenses can be made only after a formal demand has been made to the municipal council for a special deliberation on the subject; a prefect's order requiring an addition must be issued in the council of the prefecture; and additions for obligatory police expenses in all cities of over 40,000 population should be made by a presidential order reported in the Council of State. If necessary to secure revenue for such additional expenses, the prefect or president may require an additional tax or loan.

A comparison of the obligatory and optional expenditures in the following list will show that the obligatory list contains most of the important objects of expenditure :-

\section{Obligatory Expenses : -}

Maintenance of city hall and repairs of public buildings.

Preservation of communal archives and bulletin of laws.

Census and electoral assemblies.

Civil registers. 
Salary of municipal receiver.

Salaries of police and watchmen.

Quarters for justices of the peace.

Public instruction.

Care of dependent children and insane in department institutions.

Maintenance of cemeteries.

Rural roads; plans and grades of city streets.

Payment of debt.

Optional Expenses :-

Maintenance of street parements.

Maintenance of fire-engines.

Public lighting.

Poor relief and subventions to hospitals.

Salaries of special teachers in elementary schools - singing, drawing, and gymnastics.

Supplement to salary of priest or minister.

Public celebrations.

Unforeseen expenses.

Management of Municipal Funds. - Municipal funds are received and paid out by an official known as the municipal receiver. In small communes the local collecting agent of the national revenues, known as the percepteur, acts also for the local treasury. But in any city where the ordinary budget is over 30,000 francs a year, there may be provided, at the request of the municipal council, a special municipal receiver. This officer is appointed by the prefect in communes whose revenue is less than 300,000 francs, and by the president on the proposition of the minister of finance, in larger communes. In either case the municipal council submits three nominations; but the appointing power may decline to appoint either, and if no acceptable names are presented may decline to make any appointment, leaving the municipal finances in the hands of the percepteur.

The receiver or treasurer is immediately responsible for the collection of the revenues, under the surveillance of the mayor, and has the authority and duty of enforcing all payments due to the municipal treasury. He has also some control over payments, but the primary responsibility for these rests with the mayor. Only in Paris is there a controller, appointed by the prefect of the Seine. Elsewhere warrants 
for payments are issued by the mayor; and the municipal receiver may refuse payment only (1) if they are not drawn on a definite account or exceed the appropriation for the account; (2) if the proper documents are not attached; or (3) if there are no funds in the treasury.

Both mayor and receiver are required to keep detailed books of accounts, and these two sets of accounts act as a check on each other. Each officer must submit an annual detailed report of receipts and expenditures, showing under each item the budget estimates and the actual transactions. These reports go to the municipal council, which examines them in connection with its study of the budget for the coming year. But the more important examination and audit is that made by the higher administrative authorities.

Central Audit. - The accounts of the mayor receive their final examination and approval by the prefect; and this examination seems to be simply a comparison of his accounts with those of the receiver. The latter are subject, after the examination by the municipal council, to another administrative examination by the receiver of finances (an agent of the national finance ministry), and then to a judicial audit by the councils of prefecture for small communes, and by the national Court of Accounts for all communes whose income is over 30,000 francs a year.

While for the great majority of communes the final audit is performed by the councils of prefecture in the departments, the accounts of the 625 communes sent to the Court of Accounts (including roughly those with over 4000 population) are of most importance to our subject. The Court of Accounts is composed of a first president, three division presidents, eighteen master counsellors, twenty-six referendars of the first class, and sixty referendars of the second class, all appointed for life by the President of the Republic. There is also a body of twenty-five auditors, young men in training for the higher positions. These auditors are selected by examination from candidates who are licentiates in law, at least twenty-one years of age and not over twenty-eight years. 
There is also attached to the court a public attorney and a marshal. 'The first president and public attorney have each a salary of 30,000 francs a year ; the division presidents each 25,000 francs; counsellors, 18,000 francs ; marshal and referendars of the first class, 12,000 francs ; referendars of the second class, 8000 francs ; auditors, 3200 and 2000 francs each.

The jurisdiction of this Court of Accounts includes the whole field of public finances in France: State, local, and certain semi-public institutions. It has original jurisdiction over the accounts of the State and the accounts of municipal receivers for communes whose annual revenue exceeds 30,000 francs. It acts as a court of appeal from the councils of prefecture in reference to the accounts of smaller communes. We are here concerned only with its examination of municipal accounts. When these accounts are received, they are distributed by the first president to the referendars, under the regulation that no referendar receives the accounts of the same official twice in succession. The referendar must verify and audit all the accounts submitted to him, and present a report to the division of the court to which the account belongs. This report is then examined by one of the six master counsellors in the division, who also tests the referendar's work by examining part of the accounts. The report of the counsellor is then made to the division, and after discussion with the referendar the decisions are made by a majority of the seven members of the division.

A provisional decision is first rendered ; and the official whose accounts have been examined has an opportunity to submit an answer to any changes or disallowances in his accounts; but this must be submitted within two months, after which the court renders its definitive order. This can be attacked only on the ground that the legal formalities have not been complied with, for which an appeal may be taken to the Council of State. On all questions concerning the accounts themselves, the decision of the Court of Accounts is final. The orders of the Court of Accounts simply correct the financial statements, by ordering payments to be made to cover errors; but they cannot impose any penalty 
for fraud. If there is any evidence of fraud, the Court of Accounts reports the matter to the minister of finance, who refers it to the minister of justice, by whom action will be begun to bring the offender before the proper court.

The criticism is made on this system of central audit, that it does not establish an effective control over expenditures. No close inspection is made of the accounts of the ordonnateurs, or officials who issue warrants for payments, while these officials are members of the active administration. Thus in the municipal system, the mayor, who is at the head of the administration, also performs the functions of a comptroller in American cities, and his accounts are not subjected to a detailed audit. It should, however, be said that the receiver plays a more important part than the treasurer of American cities, and on account of the elaborate control over the budget is able to confine expenditures to purposes authorized.

\section{Italy}

In Italy the budget procedure and the management of municipal funds are similar to those in France. There is also a national Court of Accounts, which has appellate, but no original, jurisdiction over the audit of local finances. The original audit is made by the councils of prefecture in the various provinces; but this system does not involve any novel features requiring special attention.

\section{Germany}

In Germany, and notably in Prussia, the central control over municipal finances is much weaker than in either France or Italy; and there is consequently less compulsory uniformity of municipal accounts. Nevertheless, the professional and permanent character of municipal administration has apparently secured a high degree of system and uniformity of methods.

The Prussian cities may be taken as the best examples of the German system of municipal finance administration. In these, the municipal budgets are drafted by the board of 
executive magistrates, by which it is presented to the elected council; and after full discussion the definitive budget is adopted by resolution of the council, without the necessity for preliminary examination and approval by the higher administrative authorities. After its adoption, however, the budget is submitted to the district prefect (Regierungspräsident), who may insert any item of obligatory expense omitted in the budget, the city having the right to appeal from his action to the higher administrative court.

General control of the municipal treasury is one of the functions of the board of magistrates. The immediate management of the finances is assigned to a chamberlain or treasurer in the eastern provinces, in Schleswig-Holstein and Frankfort-on-the-Main; but in Hanover and the Rhine province this is one of the functions of the burgomaster. There are in either case various subordinate officers, such as collectors, bookkeepers, and cashiers; but all are municipal officials, and there is no appointee of the central government, like the municipal receivers in France.

The audit of accounts is also made by municipal officials. The board of magistrates makes the first audit, and presents the accounts with its report and comments to the council. The council conducts a second examination and revision of the accounts, after which they are definitively adopted by resolution. In Schleswig-Holstein there is an audit made by a joint committee representing the magistrates and council, and the report of this committee is examined by each body and adopted. These examinations are not limited to proving the calculations and comparing the accounts with the vouchers; but are also to test the legality, methods, and carefulness of the entire administration. There does not appear to be any such official as the American comptroller, whose voucher to an account is necessary to its payment. While there is no audit of the accounts by the higher administrative authorities, a copy of the accounts (in the western provinces) or the resolution of the council (in the eastern provinces) must be sent to the district prefect, for inspection, who may enter a protest against any obvious mistakes. 


\section{United Kingdom ${ }^{1}$}

Municipal finances in British towns are for the most part under the control of the various local authorities; but there are some important forms of central control. On the whole this central control is stronger than in Prussia, but much weaker than in France.

In the preparation of their budgets of annual receipts and expenditures, the authorities of each city have complete freedom, and moreover the different authorities in each city act entirely independently of the others. Every town council, school board, board of poor law guardians, or other authority has a finance committee, which prepares and submits the provisional budget, and this is discussed, amended, and adopted by the larger body. These budgets do not even have to be reported to the central authorities, as in Prussia. There are, however, two classes of financial transactions which require the previous approval of a central authority : the purchase and disposal of property, and the making of loans. The latter is the more important; and the control exercised by the Local Government Boards of England, Scotland, and Ireland over local indebtedness is more efficacious and at the same time more flexible than the fixed constitutional or statutory debt limits in the United States. The valuation of property for the purpose of the various local taxes for the different authorities is performed by the poor law authorities; or, rather, the poor law valuations are generally accepted by the other authorities. But a town council may cause an independent valuation to be made, if they do not consider the valuation for the poor rate a fair criterion.

While the preparation of budgets and the assessment and collection of taxes are thus in the main free from central control, the disbursements of all but one class of local authorities are audited by agents of the Local Government Boards. The class excepted is the most important class of urban authorities, the councils of the municipal boroughs

1 M. R. Maltbie, English Local Government of To-day, chs. 6, 7. 
(except the newly created boroughs within the county of London). In each provincial municipal borough there are elected two auditors, who examine the financial accounts of the borough council and its various committees. It will be seen that these elected auditors occupy the same position independent of the spending officials as do the American comptrollers. The authorities whose accounts are examined by the district auditors of the Local Government Boards include: the poor law guardians, councils of urban districts not boroughs, school boards, parish councils, county councils, the councils of the metropolitan boroughs, and three provincial town councils by special act.

All of the local authorities, however, - the town councils as well as those whose accounts are subject to the central audit, - submit reports to the Local Government Boards of the completed financial transactions at the close of each year. From these reports are compiled the valuable statistics of local finances published in the British Local Taxation Returns. 



\section{PART IV}

\section{MUNICIPAL ORGANIZATION}





\title{
PART IV - MUNICIPAL ORGANIZATION
}

\author{
CHAPTER XVII
}

\section{The CounciL}

Authorities. - F. J. Goopsow: Comparative Administrative Law ; Municipal Home Rule. - J. F. Dillon: Law of Municipal Corporations. C. B. Elliotr : Law of Public Corporations. - Horr and Bemis : Municipal Police Ordinances. - M. BLock : Dictionnaire de l'Administration Française. - Leıdig: Preussisches Stadtrecht. - Th. Ducroce : Cours de Droit Administratif.

Ar the centre of the local municipal organization in all cities of the civilized world is a council, a number of administrative officers, and a single official known as the maire, mayor, or burgomaster. The powers and the relative influence of these organs over the whole field of municipal administration varies to the widest possible extent. In England, on one hand, the council has the entire scope of authority and responsibility; while at the other extreme are France and some cities of the United States, where the mayor has full control, and the council occupies an insignificant place. It is necessary now to examine the position and functions of mayor and council separately, after which we may discuss the question as to the proper distribution of authority between them.

As has just been indicated, the general position of the council in the municipal organization varies greatly. In England it is the all-important local authority, and this supremacy of the council is the most distinctive feature of the English municipal system. The borough council, however, has no control over the school board or poor law guardians; and it might be more proper to speak of the 
English system as one of several local councils, each independent of the others. The borough councils and other boards are also subject to the control of the central government. In Germany there is an elected assembly and a board of executive magistrates, which together have full local control over the municipal government; and as this includes the schools and charities, it is a more comprehensive authority than that of the English borough councils. The elected assembly is the determining authority on all matters of local legislation, although the magistrates may refuse to execute any ordinance pending an appeal to the provincial authorities concerning its legality; and the members of the assembly also take an active and important part in the administration of municipal affairs, under the direction of the magistrates. The municipal council in France is not expected to engage in the active work of administration, and is mainly concerned with general decisions and the annual budget. The council in America originally occupied the same position as in England; but its powers and influence have steadily diminished, and in some cities it has now little or no authority. The creation of independent departments has been carried further than in England; important powers of the council have been transferred to the mayor; while in many cases even its control over the budget has been limited, and in some practically destroyed.

\section{ORgANIZATION OF COUNCILS}

In England the borough council consists of two classes of members : the councilmen, elected by popular vote, and aldermen and mayor, elected by the council; but both classes sit together in one body, which, as a whole, exercises the powers of the municipality. In Scotland the council is also unicameral, but comprises no aldermen. On the continent of Europe a single-chambered body is, strictly speaking, the rule; and the council there consists of but one class of elected members. But there is also in these countries a board of the executive officials, which has many of the char- 
acteristics of a second chamber; and a second chamber of this kind has the distinct merit of representing a different element from the other chamber.

In the United States there is now no certain or uniform rule. In the early days the American councils, like the English, were unicameral, with two classes of members ; but at the present time there are either two elected chambers, or a single chamber with one class of members. The latter is the prevailing type for the smaller cities. In 1892, out of 376 cities with over 8000 inhabitants, only 82 had a bicameral council. Most of the large cities have, at one time or another, had a bicameral council ; but many of them have returned to the single-house system. The unicameral plan is now found in Chicago, Cleveland, San Francisco, Cincinnati, Detroit, Milwaukee, Minneapolis, Rochester, Syracuse, Denver, New Orleans, Troy, Indianapolis, and Columbus. The bicameral system is still continued in Philadelphia, St. Louis, Boston, Baltimore, Buffalo, Providence, St. Paul, and Louisville, and generally in New England and Pennsylvania.

Second chambers in American cities are radically different from the executive boards of the cities of continental Europe. The members are not executive officers, but, as in the larger chamber, are elected by popular vote, and frequently are elected by the same districts. The most general difference is that their terms are in most cases for a longer period; but in St. Paul, Buffalo, and a few other cities, the aldermen are elected on a general ticket or by large districts, whereas the council are chosen by wards. Atlanta has councilmen elected by wards, and aldermen elected on general ticket; but both bodies meet as a single house, except when passing the budget or creating debt. In Memphis the council consists of the members of two elected boards the fire and police commissioners and the board of public works - meeting as one body. In a few American cities something resembling the executive board of the cities of continental Europe has developed. In Chicago and Cleveland the heads of the principal departments hold periodic meetings, and are known as the mayor's cabinet. The 
boards of estimate consist usually of several department heads, but do not include the whole of this class ; and moreover this board is found as generally in cities where there are two-chambered councils as in those which have the single elected house.

The size of the municipal councils is also a very variable quantity; but those in Germany, Switzerland, and Italy usually have a larger membership than those in other countries. The London County Council consists of 137 members; the Liverpool council has 116 members; Manchester, 104; Birmingham, 72; and Leeds, 60. In Germany, the Berlin elected council has 126 members; Hamburg, 160; Breslau, 102 ; Leipzig and Dresden, each 72 ; Munich, 60 . In Italian cities of over 250,000 inhabitants there are 80 members in the city councils; cities with a population between 60,000 and 250,000 have 60 members. The Vienna council consists of 138 members, and that of Budapest of 400 . In France, Spain, and Holland, the councils of large cities are distinctly smaller. In these countries, as in Italy, there is a fixed graded scale according to the population. In France, this scale begins with $\mathbf{1 0}$ members for communes of less than 500 inhabitants, and rises to 36 for cities of over 60,000 , with special exceptions which give the council of Lyons 54 members and that of Paris 80 members. In Holland, the number of members in the councils of large cities is 39 ; and in Spain, 33.

In the United States there is no uniformity; but for the most part the municipal councils are smaller than in England, Germany, and Italy. Philadelphia, with 41 members in the Select Council and 146 in the Common Council, is a distinct exception among American cities. Fairly large bodies are found in New York, where there have been 29 members of the council and 60 aldermen, and will be 79 members in the single-chamber system which takes effect in 1902; in Chicago, with 70 aldermen; and in Boston, with 12 aldermen and 75 councilmen. St. Louis has 28 members in the House of Delegates and 13 in the Council. Providence has 10 aldermen and 40 councillors. Milwaukee has 42 mem- 
bers in its single chamber. Other cities have distinctly small bodies : Baltimore has only 8 aldermen and 24 councilmen; Buffalo, 8 aldermen and 25 councilmen; St. Paul, 9 aldermen and 11 councilmen; Cleveland, 20 members in the single chamber of its council; Cincinnati, 31; Minneapolis, 26 ; Rochester, 20 ; Syracuse, 19 ; Troy, 13 ; Denver, 16 ; Columbus, 19 ; and Atlanta, 6 aldermen and 14 councilmen.

The term of service for members of municipal councils ranges in the principal countries from one to nine years. The longest period is found in Bavaria, where one-third are elected every three years. Prussia, Austria, Hungary, Holland, Belgium, and the city-state of Hamburg have six-year terms. In Hamburg, Belgium, and Hungary, one-half of the membership is elected every three years ; in the other countries named, one-third every two years. The Italian municipal councillors have a five-year term, with one-fifth of the council elected every year. In France and Spain the elections are for four years; in the former country the entire council retires at the same time, and in the latter, one-half of the members are elected every two years. In Saxony, and in Great Britain for the popularly elected councillors, the term is three years, with renewal by thirds every year, - except that in London the whole body is elected every three years. The aldermen of the English councils are elected by the councils for six-year terms, and one-half every three years. There is, of course, no universal rule for the United States, and the practice varies from one to four years. New York and St. Louis have two-year terms for the larger chamber, and four years for the smaller, renewing the former body as a whole, and the latter by halves every two years. The Chicago and Cleveland councils are chosen for two years, one-half every year. In Boston the councilmen are elected for one year, and the aldermen for two years. In Cincinnati and San Francisco the term is two years. In Philadelphia the members of the Common Council serve for two years, those in the Select Council for three years. In Buffalo the aldermen are elected for three years, one-third every year. In New Orleans the term of the councilmen is four years. 
The various systems of representation in electing municipal councils present many complications and several distinct problems. There are systems of district elections, and elections by general ticket; elections by classes of voters, and minority or proportional representation. As between district and general tickets, the English and German cities have followed the district plan, by which each district elects a single member at each election. In France, Belgium, and Italy the communes elect their councils on a general ticket, but in the large cities of Italy and France there may be a number of large districts, each of which elects several councillors. In France each municipal district elects at least four members of the council; and the district boundaries are fixed, while the number of members assigned to each is adjusted from time to time according to population. In America the election of one member by each district at each election is still the general system, especially for cities with singlechambered councils. But where there are two chambers, although the larger house is usually elected on the district plan, the smaller chamber is not infrequently elected on a general ticket. This is the case in St. Louis, Buffalo, Louisville, and Atlanta. In San Francisco the board of supervisors which occupies the position of municipal council is elected by general ticket for the whole city.

It is often urged that the district system constitutes one of the main factors in the election of inferior men to the municipal councils of American cities. It seems reasonable, too, that single-member districts with artificial and changeable boundaries, and the requirement that aldermen must be resident in their own wards, do have some effect in securing the election of petty men. At the same time, to elect the whole body on one general ticket in a large city makes it possible that large sections of the city would have no official representation. The large district with well-defined boundaries and distinct local interests, and with power to elect a number of members instead of one, seems to be the best plan, although even here there is need for some system of minority representation, to prevent small majorities in 
several districts from securing a preponderating influence in the council.

The general principle of election is, that within each district each voter casts a vote for every position, and the plurality of votes decides the result. In the case of election by general ticket, however, a small plurality will elect the whole number of members, and allow no representation whatever to a large minority of voters. To obviate this, numerous schemes of voting have been devised; and several of them have been put in operation in a few places. Thus, a law of 1893 provided that, at the election of the Boston aldermen, chosen on a general ticket, no elector should vote for more than seven of the twelve aldermen to be chosen. Under this plan, each party nominated only seven candidates; so that, while the minority party was certain of representation, the power of the party machines was increased, since a nomination by either of the two powerful parties was almost equivalent to an election. New York city formerly had a somewhat similar plan. A law of 1849 provided for a board of ten governors of the almshouse, two to be chosen each year. The candidate receiving the highest number of votes was elected, and the candidate receiving the next highest number was to be appointed by the mayor. In 1857 the Board of Supervisors of New York County was organized on a similar plan, six members to be elected by a majority vote, and the six candidates having the next highest number of votes to be appointed. In 1869 the Board of Education was organized on the same basis, with seven elected members and five appointed ones. All of these arrangements in New York and Boston have, however, been abolished.

A system of cumulative voting has been adopted in the election of English school boards. Under this system each voter has a number of votes equal to the number of members to be elected; and these votes he may cumulate on one candidate, or distribute as he chooses among several candidates. The same method is followed in electing the members of the House of Representatives in Illinois.

Various elaborate schemes of proportional representation 
have been devised, and some practical experiments have been made in Belgium and Switzerland. None of them, however, have been wholly satisfactory. The principal objections to all suggested plans for minority and proportional representation is that they render strict party discipline more necessary, and so increase the power of the party machine and diminish the power of the independent voter.

In Prussia and Austria the voters are divided into three classes: the large taxpayers, the middle taxpayers, and the small taxpayers, each of which elects one-third of the members of the municipal councils. The cities of Hamburg and Bremen have also elaborate systems of class representation in the election of their governing councils, under which the merchants, the landowners, and the artisans, have each their own distinct representatives. In Budapest one-half of the council are chosen by the 1200 largest taxpayers.

The most general legal qualifications for members of municipal councils are age and residence, with, less frequently, property requirements. The residence requirement is most strict in the United States, where the aldermen must be resident within the city, and, in practice, must also be resident within the ward from which they are elected. In France all city taxpayers are eligible, even if not residents or voters; but the number of non-resident councillors may not exceed one-fourth of the total membership. In Prussia every taxpayer is a voter, and as such is qualified for membership in the council. In England, any local taxpayer who resides within fifteen miles of the borough may be elected to the council from any ward in the borough. In Germany, a certain proportion of the council, usually one-half, must be property owners in the city; while in Leipzig, Dresden, Chemnitz, and some other cities, the law requires the other half to be chosen from those who are not property owners. In England, a special property qualification was required of councillors up to 1869 ; but at present any elector is eligible. In the United States, property qualifications were general into the early part of the nineteenth century, but are no longer required. 
POWERS OF MUNICIPAL COUNCILS

\section{Powers over Organization}

The powers of the council over its own organization and procedure are usually subject to serious limitations. In France and England municipal councils do not have the power of determining disputed elections, as do the Chamber of Deputies or American legislatures; such cases are decided in France by the administrative courts, and in England by the judicial courts. In America municipal charters frequently contain the provision that the council "shall be the judge of the qualifications and elections of its members." But by the common law the courts have jurisdiction over such election cases; and the general rule of interpretation is that the jurisdiction of the courts remains unless it appears with unequivocal certainty that the legislature intended to take it away. Language like that quoted above is construed to establish the council only as a primary tribunal, but does not establish its exclusive control, or prohibit the courts from investigating and deciding a case. But if the charter provision gives the council "sole," or "fixed," power of deciding elections, or if it is specified that no court shall take cognizance of such election cases by quo warranto, this would doubtless be sufficient to divest the judicial tribunals of their jurisdiction. ${ }^{1}$

In Europe the council in most cases elects its own presiding officer; but in America he is often chosen independently of the council. In Chicago, and in most small cities, the mayor, elected by popular vote, presides. In other large American cities there is usually a president of the council, elected by the whole city.

So, too, in matters of procedure there are frequent items governed by general or special laws. In France and Great Britain four regular sessions of the council each year are prescribed; but this does not prevent many additional sessions. American charters generally contain provisions gov- 
erning the method of voting in the council, the publication of proposed ordinances, and the like. In general, however, questions of procedure may be regulated by the council.

\section{General or Legislative Powers}

There is a fundamental difference in the method of conferring authority or powers on the municipal councils of the English-speaking countries, on the one hand, and of the continental European countries on the other. In the former the powers conferred are enumerated in detail; in the latter there is always a general grant of authority, followed, however, by an enumeration of limitations and restrictions on the exercise of certain powers.

Thus, in France the municipal code contains a classification of the attributions of the council in five groups, according to the degree of independent action conferred. The first class are those matters over which the council has full and final authority. Before 1884 there were a few exceptional matters of this nature, but the municipal code of that year changed the exception to the basal rule by the phrase "the municipal council regulates by its deliberations the affairs of the commune." Under this provision, the decisions of the council are definitive, unless there is some express provision to the contrary. But such resolutions must be submitted to the prefect, and may be held for a month to determine whether or not they come under any of the other classes. This general grant of authority is a fact of the utmost importance. It is true that many matters are directly subject to the approval or direct orders of the higher authorities, while the control over the finances imposes a large limitation upon the action of the council. But, at the same time, the council has an unlimited right of the initiative, together with full authority to enter into new fields of activity without waiting for specific legislation.

The remaining groups of functions are those in which the decision of the council is not final. One class of deliberations, including such matters as the alienation of municipal 
property, the making of long leases, the granting of franchises, and, as has been seen, the annual budget, must be submitted to the prefect or other authority.for examination and approval. Another class is that of deliberations, entirely subordinated, in which field the higher authorities may take the initiative and require the performance of certain duties by the council. The principal items are obligatory expenditures in the budget, assessments for taxation, and the management of elections, in considering which the council acts, not as a local authority, but as an agent of the central government. The remaining two groups include votes of advice and expressions of opinion by the councils in matters over which they have no positive authority. ${ }^{1}$

Prussian municipal laws also fail to enumerate the powers of the council. That body is given, in the widest sense, the right of control over the administration, and is the organ for expressing the will of the city. ${ }^{2}$ Moreover, the resolutions of the council are, as a rule, subject to no examination by the higher authorities; although if the city magistrates doubt the legality of a measure, they have power to delay its execution until it has been examined and reported on by the provincial officials. Neither in France or Prussia, nor generally in continental Europe, do the municipal councils have any authority over the police or police regulations. The principal exception to this rule is in Belgium, where the councils have the authority to enact internal-police regulations, subject, of course, to the general laws. The decisions of the Belgian councils are subject to examination, and, in many cases, require the approval of higher authorities; but this control is exercised, not by the representative of the central government, as in France, but by the executive committee of the province, a body chosen by the elected provincial diet.

In England, as has been stated, the definite subjects over which the municipal councils have authority are enumerated in great detail. At the present time the most important

1 Ducrocq, Cours de droit administratif, I, 377-410.

${ }^{2}$ Leidig, Preussisches Stadtrecht, pp. 102, 105. 
powers are conferred by means of general statutes, and some indication of the scope of their authority is given in the following facts concerning some of these statutes. The $\mathrm{Mu}$ nicipal Corporations Act of 1882 is concerned mainly with the organization of borough councils, and has only two comparatively brief chapters on the powers of the councils. One of these regulates the administration of justice ; and the other, the police department. They together include 47 clauses, covering 23 pages in the statute book, out of a total of 96 pages for the entire act. ${ }^{1}$ But by far the most important statute conferring powers on municipal councils is the Public Health Act of 1875. This act contains 343 clauses, and covers 152 pages in the statute book. The headings of the principal divisions will indicate the powers conferred:-

Sanitary Provisions : 130 clauses, covering 39 pages.

Sewerage and Drainage.

Scavenging and Cleansing.

Water Supply.

Regulation of Cellars, Dwellings, and Lodging-houses.

Offensive Trades.

Infectious Diseases and Hospitals.

Prevention of Epidemic Diseases.

Local Government Provisions : 29 clauses, covering 11 pages.

Highways and Streets, including Street Lighting.

Public Pleasure Grounds.

Markets and Slaughter-houses.

Police Regulations, referring to the Town Police Clauses Act of 1847, which contains 72 clauses, covering 21 pages.

General Provisions : 34 clauses, covering 13 pages.

Contracts.

Purchase of Lands.

Arbitration.

Officers.

By-laws.

Rating and Borrowing Powers : 44 clauses, covering 21 pages.

Other,general statutes indicating the powers of borough councils, which must be studied for a comprehensive knowledge of their authority, are the Tramways Acts, Baths Acts, Libraries Acts, and Allotments Acts; while for all of these 
there is a mass of supplementary and amending acts. Furthermore there is the extensive legislation on poor relief and education, conferring authority on the poor law boards and school boards.

Not all of the powers enumerated thus in detail may be exercised by the councils entirely at their own pleasure. In many cases the powers are mandatory, while in others the acts are permissive in nature. The mandatory provisions may be enforced by actions in the courts; while the Local Government Board and other central authorities have powers of compulsion. In undertaking to perform a permissive function, too, a council must secure the approval of the Local Government Board in a provisional order, which is afterward formally confirmed by the passage of a Provisional Order Act through Parliament. These are in form much the same as the special statutes of American legislatures; but they are all based on general principles laid down in a general statute, and the practical control is exercised by an expert authority, while the parliamentary action is purely formal. There is, however, a considerable amount of distinctly special legislation enacted, particularly for London and some of the other large cities, when the councils wish additional powers. For such cases there is a definite method of procedure, by which the council makes application for the authority desired, public notice is given, and a thorough public examination of the matter is held by the Private Bill Office, before the opening of Parliament.

In the United States also the system of enumerated powers is followed, and here it results in a much more extensive mass of legislation. This is due in part to judicial action. The ruling of the courts has been that municipal corporations in their public capacity possess such powers, and such only, as are expressly granted by statute, and such as may be implied as essential to carry into effect those which are expressly granted.1 "It is a general and undisputed proposition of law that a municipal corporation possesses and can

145 Ohio State, 118. 
exercise the following powers, and no others: first, those granted in express words ; second, those necessarily or fairly implied in or incident to the powers expressly granted; third, those essential to the declared objects and purposes of the corporation - not simply convenient, but indispensable. Any fair, reasonable doubt concerning the existence of power is resolved by the courts against the corporation, and the power is denied." 1 This interpretation of strict construction in connection with the traditional system of enumerated powers has tended to increase the mass of provisions in municipal charters, since every particular item must be declared beyond doubt. The mass of legislation enacted is, moreover, necessarily voluminous from the fact that it proceeds from so many different legislatures. Each state enacts laws only for the cities within its limits ; and even the general legislation for all of the states must include a vastly larger amount than that for England. But the volume of legislation specifying municipal powers is still further, and to a vast extent unwarrantably, increased by the custom of American legislatures of enacting special statutes for all of the more important cities, and by inserting in municipal statutes details of municipal organization and the duties of administrative officers and departments.

In the general Municipal Incorporation Act of Illinois, the powers of the council are enumerated under ninety-six heads; the law of Ohio gives fifty different subjects; the general law of Pennsylvania names forty-six purposes for which cities of the second, third, and fourth classes may enact ordinances.

Police Powers. - The most important class of ordinance powers possessed by American municipal councils are those classed under the head of the police power. The police power is the governmental power possessed by the state legislature for the purpose of promoting the general comfort and welfare of society, and as such may be delegated by the legislature to a local corporation. But the nature

1 Dillon, Municipal Corporations, I, 145. 
and scope of this power has never been subject to exact definition and limitation, and is incapable of exact description. It includes the protection to the lives, persons, and health of the people, and to property. The powers of the legislatures under this head are nowhere defined, and the exercise of the power is limited only by the decisions of the courts in applying the specific restrictions of the national and state constitutions. On the other hand, the powers delegated to municipal corporations are ordinarily specifically enumerated, with an added general provision authorizing the exercise of powers necessary to preserve the peace and good order of the community, and to promote the public welfare. The general grant, however, does not authorize ordinances upon any subject which is partially given by an express grant; and where nearly all the ordinary powers are mentioned specifically, only such additional ones can be exercised under a general grant as are absolutely essential to the welfare of the community.

Under a general grant of police power the following functions have been held to be properly exercised : ${ }^{1}$ -

1. For the promotion of the health of the community: the regulation of markets and slaughter-houses; the prohibition of swine breeding or rice cultivation within certain limits ; sanitary regulations.

2. For the protection of the public morals : the regulation of the traffic in intoxicating liquors, and of bawdyhouses; the prohibition of lewd women from serving in saloons and restaurants or loitering on the streets.

3. For the promotion of personal security and comfort: ordinances to repress and restrain assaults, riots, disorderly conduct, unlawful assemblies, and breaches of the peace ; to punish attempts to aid prisoners to escape; to regulate the keeping of dogs, requiring the use of muzzles, and authorizing police officers to kill dogs found at large and unmuzzled; to regulate the speed of railroad trains within the corporate limits; to restrain and impound stray animals; to provide for the prevention of fires ; to suppress vagrancy ;

1 Horr and Bemis, Municipal Police Ordinances, pp. 192-201. 
to regulate the observance of the Sabbath; to regulate the use of the streets; and to prohibit deposits of rubbish except at designated places.

But it has been held unlawful under the general police power to punish assault and battery, to grant the privilege of erecting and maintaining toll bridges, to require cotton merchants to keep a record of their sales, to order the removal of buildings held to be within the street line, or to levy any form of taxes.

Health Regulations. - The power of caring for the health of the community includes, generally, the power to enact ordinances for the removal of offal, the cleaning of streets, the location and use of cemeteries, the erection and maintenance of infectious diseases hospitals, the quarantine of vessels and trains, the public water supply, the sewerage system, the purity and wholesomeness of food and drink; to establish markets, and to regulate the conduct of all trades, employments, and businesses which "tend to pollute the air or the earth." Generally, also, boards of health may be (or must be) organized with full power of detailed supervision. The only definite restriction on the power to pass ordinances regulating things that affect health, and to provide detailed regulations through a board of health, is, that the ordinances and regulations must not be used as a cloak for other kinds of regulation.

Suppression of Nuisances. - Municipal corporations are, as a rule, liberally endowed with power to abate and prevent nuisances. This term includes all conditions which are detrimental to health, dangerous to life, or productive of serious inconvenience. The power is, however, subject to strict judicial control. It can be exercised only when the act or thing is an actual nuisance. The municipal corporation cannot make a thing a nuisance by declaring that it is one, and ordinarily there must be a judicial determination that the thing complained of is a nuisance; but the municipality may be given power to abate nuisances summarily. The 
following have been held to be nuisances: articles exposed for sale which are unfit for use; public exhibitions of studhorses; deposits of rubbish; smoke from chimneys; houses of ill-fame; swine running at large; keeping swine. Other conditions, which are not nuisances per se, may become such under special circumstances. Such are a blacksmith's shop, pigpen, or cow-stable in proximity to dwelling-houses, and cemeteries. In order to establish the "nuisance" character of this latter class, it must appear that they cause some positive inconvenience, damage, discomfort, or menace to life or health.

Licenses. ${ }^{1}-$ The power to license occupations and amusements must be plainly conferred or it cannot be exercised by a municipal corporation. A license may be either a police regulation or a tax. If the former, it must be for the purpose of preventing some threatened evil, and must not exceed in amount a sum sufficient to cover the expenses of issuing the license and of police supervision. In the latter case its validity is governed by the principles governing taxation.

Fire Prevention. - A municipal corporation in the exercise of its powers to protect the lives and property of its citizens, and without express grant, may take all reasonable steps to prevent the rise and spread of conflagrations. It may prescribe fire limits, and prohibit the construction of wooden buildings within such limits; in most cases this power is inherent in the corporation, but in Pennsylvania, Iowa, and Texas it has been held necessary to secure an express grant. Generally, this power cannot be so interpreted as to authorize the city to tear down existing buildings, unless they are in unusually bad condition; but the city is authorized to prevent the erection of buildings already contracted for, even if the foundations have been laid. Repairs of an ordinary character on buildings cannot be prohibited. As a means of preventing the spread of fires, the

1 Elliott, Law of Public Corporations, pp. 89 ff. 
purchase of fire-engines may be made by a municipality, without express power.

Local Courts. - By the common law, municipal corporations have power to establish courts for the purpose of determining controversies of limited and local importance, and such courts are either authorized or directly established in modern municipal charters and laws. The jurisdiction of these municipal courts ordinarily extends to the enforcement of municipal ordinances and the recovery of penalties for breaches thereof, and to controversies between individuals involving only a small amount. They are often empowered to determine civil suits, when the amount involved does not exceed $\$ 500$, and when title to land is not involved. The procedure in municipal courts is ordinarily of a summary nature; and the constitutional right to a jury trial has never been understood to apply to violations of city ordinances.

Streets and Highways. - The state legislature has permanent authority over the streets and highways of a city, and may delegate this power to municipal corporations. But the legislature cannot prevent the use of streets for proper purposes. Ordinarily, the control over city streets is given to the municipality.

An abutting property owner has certain rights and interests in the streets in addition to the rights of the general public. He is dependent on them for sewer, water, and gas connections; he has to pay for these connections, and also has to contribute toward the cost of sidewalks and pavements. The special rights of the property owner are property rights, and as such are under the protection of the United States Constitution against violation even by the state legislature, whether the fee of the street is in the lot owner or in the city.

The extent of municipal control over the streets is limited to the powers granted in the charter or general law, or that necessary to effectuate that which is granted. The usual powers are to establish alignment, to grade, to repair, and 
to pave. The power to grade implies the power to raise or lower materially portions of a street in order to facilitate traffic. Power to repair does not include power to lay new pavement or to macadamize a road. Power to pave, however, includes power to grade, to provide gutters and curbstones, and even sidewalks.

As part of the general police power, municipal corporations have the power to protect and guard the streets from injury. They have the right to regulate traffic and heavy loads, to protect trees, to regulate and prevent obstructions. The right to compel property owners to remove snow is, however, not always granted to municipal authorities. On the other hand, express grants are necessary to entitle a municipal corporation to authorize such obstructions as steam or street railways, telegraph or other poles, and underground pipes for gas, water, or sewers. Where such authorization is given, it may be on terms and conditions, and these conditions will be enforced by the courts.

Schools and Charities. - Municipal corporations may also be made the agent of the state for administering the educational and poor relief system. Special local authorities are, however, often created, with powers more or less independent of the municipal councils. These powers of school boards are purely statutory.

Taxation, Special Assessments, and Power of Eminent Domain. - The power of taxation is an attribute of sovereignty ; and in contemplation of law it is always imposed by the state, although it may act through the agency of a municipal corporation. Most municipal corporations have received the power to levy taxes for certain purposes. Ordinarily this power is conferred in express terms, but it may be implied; when a municipality is expressly empowered to borrow money, for example, it has implied authority to levy a tax to meet the obligation. But the mere fact of incorporation does not carry with it any power of taxation. The legislature may confer the power of taxation subject to such limitations (as 
to purposes, rate, and objects) as it deems expedient, but caunot confer any greater power than the state itself possesses, and must also observe the limitations of the state constitution. The power cannot be granted in perpetuity, but may be revoked at any time. The power can be legally exercised for public purposes only.

Expenses for making local improvements, such as grading and paving streets, constructing drains, sewers, and the like, are very generally met, in whole or in part, not by a general tax, but by special assessments authorized to be made upon the persons or property benefited or deemed to be benefited. Such special assessments are now clearly recognized to be within the power of the legislature to authorize, but before a municipality may exercise this power, it must show legislative authority therefor. Authority to levy special assessments, even when duly granted by the state, does not include authority to confiscate property for non-payment of the assessments, without due process of law or without compensation to the owner.

The power of eminent domain is also a right pertaining to sovereignty, but it may be delegated to either public or private corporations. Under this power every species of property may be taken, the fee or a mere easement may be taken, and a city may be authorized to condemn lands beyond the corporate limits. But property may be taken in this way only for a public use, and after notice and upon compensation. Public uses for which it has been legally exercised are: public roads and streets, parks, markets, cemeteries, school buildings, water and gas plants, sewers, almshouses and other public buildings. Property already appropriated to a public use cannot be taken for another public use unless the statute clearly confers authority to make the second seizure.

Property. - In addition to the governmental powers of municipal corporations, they also possess certain corporate or private powers. Such powers, however, must have some relation to their governmental duties. The most important 
power of this kind is the right to purchase and hold private property ; and it is distinctly settled that municipal corporations have this power (but only for municipal uses), and they will be protected in their ownership of such property to the same extent as a private owner. This private property of a municipality must be carefully distinguished from the public property. The latter (including the streets, sewers, etc.) is fully under legislative control, and the municipality is not liable to individuals for negligence in its care. But a municipality is liable to individuals for negligence in the management of its private property, and at the same time is protected in its possession by the courts, and cannot be deprived of it without compensation, even by the legislature. ${ }^{1}$

In a recent case in which it was maintained that a cemetery was to be considered as private property of the city, the -judge cited as similar instances the waterworks, parks, markets, hospital, and library. "In establishing all these the city (Boston) has not acted strictly as an agent of the state government for the accomplishment of general public or political purposes, but with special reference to the benefit of its own inhabitants." 2 So the rights which a municipality acquires under the grant of power to build wharves or to lease a ferry franchise are held to be private rights. Gas, water, and electric light plants may similarly be held, certainly if authorized by the legislature ; and in several states ${ }^{3}$ power to provide for "lighting the streets" or "furnishing the city with water" will authorize a city to construct its own plant. But it has been held by a South Carolina court that power to light the city streets does not give the municipality authority to furnish private consumers with light.

Miscellaneous Corporate Powers. - Unless restricted by charter or law, a municipality has implied power to make such contracts as are reasonably necessary for the purpose of carrying into effect the object of its creation. Such contracts may be for a term of years extending beyond the life of the

1 F. J. Goodnow, Municipal Home Rule, ch. 9.

258 Mass. 509.

s Indiana, West Virginia, Michigan, New Jersey. 
council, but such a contract must not preclude the council from exercising its legislative powers, create a perpetuity or monopoly, or constitute an absolute surrender of the city's control over the subject-matter of the contract. It is well settled that a municipal corporation cannot, without express authority, grant exclusive franchises or privileges, such as the right to put mains, pipes, hydrants, or rails in the streets. The legislature alone has this power, and if there is any reasonable doubt as to whether or not an exclusive franchise has been authorized or conferred, the doubt is resolved against the party claiming such a grant.

Municipal corporations have implied authority to issue warrants or vouchers for money due by the corporation. The power to borrow money, however, must be conferred by express authority, or result as an incident to an express power, coupled with the imposition of duties which are incapable of performance without the power to borrow. In the case of city corporations, express power to borrow carries with it irnplied power to issue negotiable bonds; although the opposite rule prevails in regard to counties, townships, and school districts. Such negotiable bonds may be issued only to raise money for public purposes : paving streets, constructing waterworks, supporting public schools, constructing public buildings, acquiring an electric light plant, or to furnish aid in the construction of railways; the last-named purpose, however, is prohibited in some state constitutions. Bonds may not be issued to promote private manufacturing enterprises in the city, as, for example, to build a dam to furnish water power for a paper mill.

\section{Administrative Powers}

The legislative powers of municipal councils involve a considerable degree of control over the administrative officials, since they lay down the rules which the administrative officials must carry into effect. There is, however, room for wide variations in the extent to which the councils have power to organize the administration, select the officials, and direct them in the details of their work. 
In this field the English municipal councils have the largest scope of authority. They have entire charge of municipal administration; they distribute the work of departmental management and supervision to standing committees selected from among their own members, which they organize and constitute as they please; they appoint and remove all officials, who act under the immediate direction of the council committees. The general laws require the creation of a Watch Committee to have charge of the police, and also of a School Attendance Committee in boroughs which have no school boards; but in all other respects the councils can create whatever committees they please, and the members of the councils thus take an active part in the work of municipal administration.

In other countries, the municipal councils also have long lists of committees, established and selected by the councils; but these committees do not have direct management of the administrative departments, and the councils have by no means the same control over the administration that they have in England. In France and Germany, the administrative officials (magistrates and adjoints) are chosen by the councils ; but once selected, they are, to a large extent, independent of the councils. In Germany, these administrative officers, as a rule, form a board, which jointly assigns the different members to various departments, and has general direction over the administration. In France and Western Germany the assignment of the adjoints and their general direction is in the hands of the mayor. In the United States, the councils have, in general, still less influence over the administration. The organization of the administrative departments for large cities is generally provided in the charter, and the officials are mainly appointed by the mayor or elected by popular vote, with the power of the council confined to confirming the mayor's appointments. In Illinois, the councils have the power of organizing new departments and of selecting the method of making appointments. In Pennsylvania cities of the second class (Allegheny, Pittsburg, and Scranton), the councils have elected the heads of the principal 
departments, but the power to do this has been withdrawn by the legislation of 1901 .

\section{PROCEDURE OF MUNICIPAL COUNCILS}

Although so often considered legislative bodies, municipal councils differ from legislatures for larger districts in having frequent brief sessions instead of long sessions at rare intervals. In Germany, Great Britain, and the United States, weekly meetings are the general rule in the large cities; and fortnightly, or at most monthly, intervals separate the meetings in the smaller cities. In France, the law has the legislative concept of the council's position, shown by its provision for four regular meetings in each year. But even in that country the councils of the large cities hold frequent special sessions, and the council of Paris meets from eighty to ninety times a year.

Generally speaking, members of municipal councils receive no salary, and frequently service is compulsory. Both these rules were laid down in the English borough charters and in the early American charters. In England, service is still unpaid, and officers must serve or pay a fine. In Germany the principle of obligatory unpaid service was established by the Municipal Corporations Act of 1808. In this country, however, the element of compulsory service has disappeared; and in a number of large cities the members of municipal councils receive payment, sometimes at a per diem and sometimes at an annual rate. In New York the members of the council receive $\$ 2000$ a year, and the president of the council, $\$ 5000$. In Grand Rapids, Mich., the aldermen receive $\$ 350$ each. In Cincinnati each member receives $\$ 10$ for each session at which he is present; and in New Orleans, $\$ 20$ for each regular monthly meeting, if he has attended all special meetings during the month. 


\section{CHAPTER XVIII}

\section{Administrative Officials}

THE administrative machinery presents a greater variety among different cities than any other feature of municipal government. Each city has organized its own officials and departments from time to time in accordance with local needs and local ideas; and it is impossible to present any systematic classification of administrative organization. A few general statements may, however, be made.

In France and Germany the number of officials corresponding to the American heads of departments is regulated by general laws, and varies with the size of the city. The French communes have each a mayor and one or more adjoints. Communes with less than 2500 population have one adjoint; those with a population between 2500 and 10,000 , two adjoints, and an additional one is added for each 25,000 population, with a maximum of twelve adjoints, except in Lyons, where there are seventeen, and in Paris, where this title is not used, but where there are a larger number of officials. The Prussian laws provide for a burgomaster, a deputy, and a number of Schöffen or magistrates - two in communes of less than 2500 population, six in cities of over 10,000 , eight in cities of over 30,000 , ten in cities of over 60,000 , and two additional for every 50,000 population over 100,000 . Thus in German cities the number is greater than in French cities. Berlin has 34; Munich, 34; Leipzig, 27; Dresden, 32; and Breslau, 26.

The corresponding authorities in England are the committees of the councils, and the number of these is determined by the council for each city according to its own judgment. There is no definite rule even for the number of 
committees; Manchester has sixteen committees, and Leeds fifteen. A list of the committees of the Leeds council, with the number of subcommittees in each, follows :-

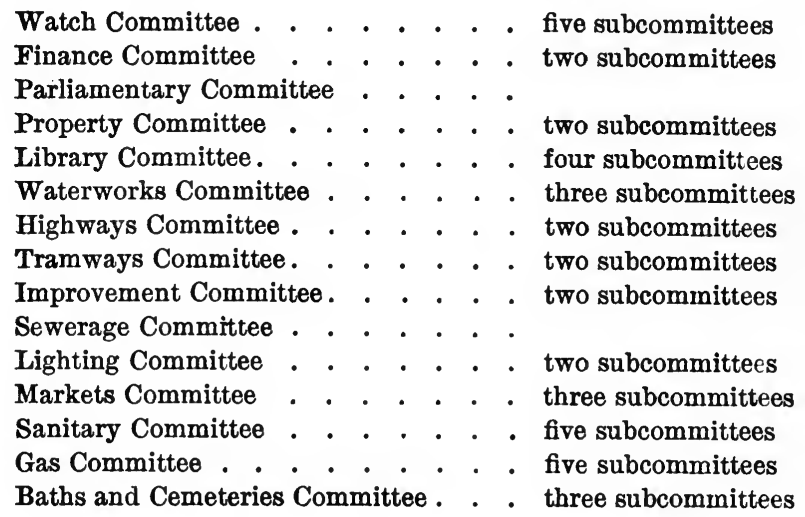

The committees of Manchester are: art gallery, baths and wash-houses, cleansing, finance, gas, general purposes, improvements, markets, parks and cemeteries, highways, public libraries, rivers, sanitary, town hall, watch, and waterworks.

In American cities the number of administrative departments is subject to no regular rule, nor is there any clear distinction between administrative and technical officials, since many of the latter are under no administrative direction. The New York charter of 1897 provides for the following eighteen main departments: finance, taxes and assessments, law, police, health, fire, building, highways, water supply, bridges, street cleaning, sewers, parks, docks and ferries, education, charities, correction, and public buildings, lighting, and supplies. But there are about a score of other officials and boards not subordinated to any one of these departments. In Chicago there are departments of finance, law, public works, health, fire, police, elections, education, and libraries, with about a dozen other inspectors and superintendents, of technical branches. Cleveland has ten main departments: law, public works, police, fire, accounts, charities and correction, parks, elections, education, and libraries ; and these in- 
clude most of the municipal officials. Boston has the following thirty-three executive city departments: board of assessors, fire commissioner, board of health, city hospital, library trustees, trustees of Mt. Hope Cemetery, board of park commissioners, board of commissioners of public institutions, board of registrars of voters, overseers of the poor, sinking fund commissioners, water board, city auditor, city collector, city engineer, superintendent of ferries, superintendent of public buildings, superintendent of public grounds, inspector of milk and vinegar, inspector of provisions, superintendent of lamps, superintendent of markets, city printer, inspector of buildings, city registrar, sealer of weights and measures, city surveyor, superintendent of streets, city treasurer, water registrar, commissioner of wires, corporation counsel, board of statistics. Besides these, there are the board of street openings, the school committee, and the county officers, elected by the people; and the police board and the rapid transit commission, appointed by the governor of the state.

In addition to the mayor and common council, Detroit has twenty-six boards and officials : a board of estimates, a commissioner of sinking funds, a city clerk, a corporation counsel, a city treasurer, a receiver of taxes, three city assessors, two market clerks, a chief accountant, a city engineer, a boiler inspector, three building inspectors, a board of education, a board of library commissioners consisting of six members, a board of four poor commissioners assisted by five city physicians, a board of health of five members (comprising also a health officer, a sanitary engineer, a funeral inspector, a chemist and bacteriologist, two food and milk inspectors, two medical inspectors and disinfectors, a superintendent of contagious diseases bureau and vital statistics, two quarantine inspectors, and four plumbing inspectors), a commissioner of public works, a commissioner of parks and boulevards, six public lighting commissioners, two weighmasters, two poundmasters and wood inspectors, a police commissioner, a board of four water commissioners, a board of four fire commissioners, and a superintendent of the house of correction.

The Indianapolis administrative officers in 1900 consisted 
of a city clerk, a police judge, a comptroller, an attorney, a civil engineer, a superintendent of streets, two sweeping and sprinkling inspectors, a custodian of the city hall, a board of public works of five members, four commissioners of public parks (whose terms expire at different times), a board of public safety of three members (having general charge over the superintendent of police, the chief of the fire department, the license inspector, and the building inspector), a board of public health and charities of three members (who oversee the city sanitarian, the six sanitary inspectors, the milk inspector, the meat inspector, the city hospital, and the city dispensary), a bureau of assessments for public improvements, and a board of school commissioners consisting of five members whose terms expire at different times.

In St. Louis the following administrative officials are elective, and hold office for four years: the comptroller, the treasurer, the auditor, the register, the collector of revenue, the malshal, the inspector of weights and measures, the board of assessors (consisting of a president and ten district assessors), and the coroner. There are also the following additional boards and officials : the board of public improvements, consisting of a president and five department commissioners (namely, the street commissioner, the water commissioner, the harbor and wharf commissioner, the park commissioner, and the sewer commissioner), the commissioner of public buildings, the supervisor of lighting, the commissioner of supplies, the inspectors of boilers and elevators, the board of election commissioners, the board of health (consisting of the mayor ex officio, the health commissioner, the president of the council, the police commissioner, two appointed commissioners, and the chief sanitary officer), the counsellor, the city chemist, the milk inspector, the supervisor of plumbing inspection, the board of engineers examiners, the board of appeals, the board on charitable institutions of five members, the board of directors of the public library of seven members, the chief engineer of the fire department, the superintendent of the fire and police telegraph systems, the board of police com- 
missioners of four members and the mayor, the license commissioner, the jailer, and the board of education.

The administrative officials of New York city in 1901 consist of : five borough presidents; a board of estimate and apportionment consisting of five ex officio members; a comptroller, having general supervision of the auditing bureau, the bureau for the collection of taxes and assessments and water rents, and the bureau of city revenue and markets; a city chamberlain, who oversees the city paymaster; two commissioners of accounts; five ex officio commissioners of the sinking funds, consisting of the mayor, comptroller, chamberlain, president of the council, and the chairman of the finance committee of the board of aldermen; a department of taxes and assessments, consisting of a president, four commissioners, and fifty-six deputy tax commissioners; a board of assessors, including a president and four assessors; a board of revision of assessments, consisting of the comptroller, the corporation counsel, and the president of the board of public improvements ; a board of public improvements, consisting of a president and six commissioners, as follows: commissioners of bridges, of highways, of sewers, of street cleaning, of water supply, and of public buildings, lighting, and supplies; a law department, which has general charge of the bureau of collecting arrears of personal taxes, the bureau for the recovery of penalties, and the bureau of street openings; a health department, comprising a president, two commissioners, and the police commissioner as the board, and the superintendent of the sanitary bureau, the chief inspectors of sanitary inspection, of contagious diseases, of food inspection and offensive trades, and of medical school inspection, the director of the bacteriological laboratory, and the registrar of records as executive officers ; a board of education of nineteen members (delegates from the four borough school boards); three dock and ferry commissioners; three park commissioners, each with an assigned district; a police commissioner; a commissioner of correction; three commissioners of public charities; a fire department, over which there is a commissioner and a deputy 
commissioner, a fire marshal for the inspection of combustibles, and a chief of the brigade; three commissioners of buildings, assigned to districts, and overseeing the five superintendents of buildings; a bureau of licenses, in charge of the mayor's marshal; a board of city record, consisting of three ex officio members and a supervisor; a board of armory commissioners, consisting of the mayor, the president of the department of taxes and assessments, the commissioner of public buildings, lighting, and supplies, and two senior ranking officers of the New York National Guard in the city; a bureau of municipal statistics; a poundmaster; eleven inspectors and ten sealers of weights and measures, who have as part of their equipment thirty-nine stations for weighing coal ; nine municipal art commissioners; three municipal civil service commissioners; a board for the improvement of Atlantic Avenue; commissioners for St. Nicholas Park, Eleventh Ward Park, Speedway Park, for appraising damages for changes of grade in the twenty-third and twenty-fourth wards, for estimating the cost of Colonial Park, for the new East River bridge, and for the New York and New Jersey bridge; twenty city police magistrates ; twentythree municipal justices; and six judges of the city court. Three state boards - the tenement-house commission of fifteen members, the aqueduct commission of four members, the mayor and the comptroller, and the rapid transit commission of six members, the mayor and the comptrolleralso have authority in the city of New York.

The method of selecting the various administrative offcials is next to be considered. In England the council committees, in Germany the magistrates, and in France the adjoints, are selected by the councils. In the United States almost every imaginable method has been tried; but the most prominent methods now in use are popular election, council election, appointment by the mayor, and appointment by the state. In most cities, several of the officers are chosen by popular vote. The comptroller and treasurer of most cities are elective; and in many places police judges, assessors, 
school boards, boards of public works, and sometimes other officials, are chosen in this way. Election by the council is still used to a considerable extent, especially in the smaller cities. In Pawtucket, R.I., the council selects the treasurer, judge of probate, city solicitor, city auditor, collector of taxes, highways commissioners, and overseers of the poor. Municipal appointments by the governor or state legislature are comparatively rare. The principal cases are police boards in some of the large cities; and less frequently excise and health officials are chosen in this way. The larger number of officers are, however, appointed by the mayor, with the consent of the council. In Philadelphia the confirmation must be by a three-fifths vote of the Select Council. This system tends to divided responsibility, and also often produces a deadlock between the two branches of the appointing power. The charter of Albany provided that the mayor's selections should stand, unless rejected by a majority of all the members of the council within two meetings after the appointment is made. The more recent tendency in large American cities is to give the mayor absolute power of appointing administrative officials; and this system is found in New York, Boston, Buffalo, Indianapolis, Rochester, Syracuse, Albany, Troy, and some smaller cities.

In general there are few special legal qualifications required for the persons appointed as administrative officials. Police judges in large American cities must, in some cases, have had experience in law practice, but such requirements for other offices are rare. The system of Prussia, on the other hand, is characterized by the requirement that a portion of the magistrates (about one-half) shall be persons who have taken a long course of special professional training for administrative officials.

In England the members of council committees receive no salaries, and the adjoints in French cities are also unpaid. In Prussia the professionally trained magistrates are salaried officials, those of Berlin (excluding the mayor) at from 7,000 to 16,500 marks. In large American cities administrative officers, except members of school boards, library trustees, 
and, in some cases, park commissioners, as a rule receive salaries. Unsalaried officials in all cases devote only a part of their time to the municipal work, and there is always a salaried technical manager acting under their direction. The salaried officers, on the other hand, devote their entire time to the municipal administration.

The term of service of administrative officials is longest in Germany. In Prussia the unsalaried magistrates are elected for six-year terms, and the salaried magistrates for twelve years. In England and France the terms of corresponding officials are limited to their term as members of the municipal council, which is, respectively, three and four years. But in all of these countries reellection is frequent. In America the salaried administrative officers have terms which vary from one to a maximum of ten years, subject in a few cases to removal at the discretion of the appointing authority. Members of municipal boards usually hold office for comparatively long terms, and do not all retire at one time. In some cities (for example, in Cleveland) the terms of the department heads correspond with that of the appointing mayor; in other cities there is no agreement between the terms of the appointing and the appointed officials. Thus in New York, under the charter of 1897, the mayor was elected for a four-year term, but most of the department heads had six-year terms, although they might be removed during the first six months of the mayor's term.

The relative merits of boards and single commissioners for directing a particular field of municipal administration is an important question of municipal organization. Great Britain uses a board system in the council committees; but it must be borne in mind that these are boards of unpaid members, exercising only supervision, while in every case there is a single technical superintendent at the head of the various divisions of municipal activity. In France the single commissioner system is clearly followed in every case, in the person of particular adjoints. In Germany there are joint committees composed of councilmen and magistrates for each department; but 
these are mainly advisory bodies, and the directing authority is the single magistrate who acts as chairman of the committee. Only in the United States has the system of salaried boards been developed to any extent. The present tendency in this country, however, is toward a single commissioner system, but with important exceptions, some of which are based on distinctions in the nature of the work. Thus, nearly everywhere the schools are under the supervision of a board ; in this case, however, the board is usually unsalaried, with a salaried superintendent under its direction. In Cleveland the superintendent has complete control of the school administration, and the school board manages the finances and general regulation only. In Buffalo there is no school board, and the only limitations on the acts of the superintendent of schools are those set by the municipal council. Other departments which in many cases are under the control of boards are parks, libraries, assessments, health, and less frequently police and public works.

An important factor in the development of the board system has been the bi-partisan idea that more than one political party be represented on the board. This system has been advocated as a means of securing non-partisan appointments and of preventing the extension of the spoils system in the municipal service. More frequently, however, the objects and results of adopting the bi-partisan plan have been to divide the spoils between the two leading parties, to strengthen the hands of the party managers, and at the same time to dissipate responsibility. If two parties are equally divided there must result either a deadlock or a "deal" between the two halves of the boards. In some cases, however, boards are organized so as to give one party a majority, as in Buffalo for the police and fire departments, and in Cincinnati for the police department, where the mayor is ex officio a member of the boards.

These boards have been spoken of as bi-partisan because that in practice is what they are. It should be noted, however, that the legal provision is simply that not more than a certain number of members shall be selected from one party; 
consequently the additional members may be from any other party, or from no party at all. In Michigan a law requiring appointments to be made from the two principal parties has been declared unconstitutional, as establishing a "test" for office in violation of the fundamental law." On the other hand, in New York city a board of election commissioners has recently been established for which the two leading party committees are authorized to submit nominations, although the law does not attempt to require the appointments to be made from these nominations.

Another feature of municipal administration is the organization of the various department heads into a general board or council. It has already been noted that in some American cities single commissioners for particular branches of public work are united into a general board of public improvement, as in New York and St. Louis. But there is seldom in this country a council composed of all the department heads. The nearest approach to such a council is in Cleveland, where the heads of the six principal departments form what is known as the mayor's cabinet, which holds frequent meetings. Similarly, in New Orleans, and in the New York cities of the second class, the charters provide for meetings of the mayor and the heads of the departments for consultation and the discussion of municipal policies.

This feature is more common in other countries. In Germany the administrative magistrates form together a distinct body, which holds regular and frequent meetings, and exercises important collective authority. In French cities where regular council meetings are infrequent, meetings of the mayor and adjoints are required, although the former official has the general direction of municipal affairs in his own hands. In Great Britain the administrative committees come together in the council meetings. Such meetings of administrative officials are important and valuable in promoting the unity of administration, and the lack of them is a serious defect in the board system of municipal government.

${ }^{1}$ Attorney-general vs. Board of Councilmen of Detroit, 58 Michigan, p. 213. 


\section{POWERS OF ADMINISTRATIVE OFFICIALS}

The principal and most general duties of the administrative officials are those of directing the technical officers and subordinate employees in the department over which they have charge, according to the general principles laid down in the laws, statutes, and ordinances of the legislatures, state officials, or municipal councils. In European countries the administrative officers have usually in practice a large amount of power over the detailed organization of this subordinate service and over the appointment of the employees. But in the United States there are sometimes strict limitations placed upon their authority in these respects. The detailed organization of departments may be prescribed in the city charter by the legislature, while the system of competitive examinations of applicants for appointments is an important restriction in the appointing power of the department heads.

For example, the New York charter fixes the strength of the police force and the salaries of the policemen; and an amending act establishes minimum salaries for school-teachers with regular annual increments. In these departments, as well as others, the tenure of subordinate positions is permanent, and removals can be made only for specific cause and after a hearing. All of the cities of New York and Massachusetts have general systems of competitive examinations for positions in the civil service. In Massachusetts these examinations for the various cities are conducted by the State Civil Service Commission. In New York each city has a commission appointed by the mayor; but their rules must be approved by the state commission. City commissions have also been established in Chicago, Milwaukee, and New Orleans. Examinations for school-teachers are not held by such commissions, but under the direction of the school board.

The ordinance power of the department officials is generally confined to making rules and regulations governing their subordinates and protecting the public property under their control. Thus police boards or commissioners issue rules 
for the guidance of the policemen; fire commissioners issue rules for the members of the fire brigade; and school boards pass ordinances for the regulation of school buildings. In such cases, the rules affect the general public only indirectly. In other cases, rules for the protection of public property may impose duties and restrictions on others than municipal employees, - as when a school board regulates the course of instruction or the text-books to be used; when a dock board issues by-laws governing the use of the docks; when a park board adopts regulations for the care of the parks; when the street-cleaning commissioner issues orders in regard to the disposition of garbage and ashes; or when a water commissioner promulgates rules for the distribution of water. In some cases the power to issue orders of general interest has been more widely extended. The most important power of this sort is that possessed by some boards of health to issue health regulations and ordinances, which in some cases takes away from the councils the most important part of their power of issuing police ordinances.

Some administrative boards have even larger authority, and can adopt a general scheme. This is most often the case with elected boards or those appointed by other than municipal officials. School boards, however chosen, have generally such power to a large degree; and the same is true to an even greater extent of the independent school boards of Great Britain. Park boards in American cities, when first created, often design the park schemes of the city. Even public works boards or commissioners may have power to adopt a plan for street paving or street openings without the necessity of securing the approval of the city council. Authority of this kind is probably possessed most generally by the magistrates of German cities, although in important matters the power rests in the hands, not of a single magistrate, but of the entire board. In some American cities, and notably in New York, the power of individual department heads is greater than that of the corresponding official in Germany. 


\section{CHAPTER XIX}

\section{The Mayor}

Is all systems of municipal organization there is at the head of the government a single official, who stands as the chief agent and representative of the city. The title of this official varies to some extent. In England and America he is called the mayor, and in France he has the similar name of maire; in Germanic countries he is the burgomaster or chief burgomaster, in Italy the syndic, and in Spain the alcalde. His powers are also of widely different importance; but he is an official of great positive and relative authority in all countries except in Great Britain, where the position is merely one of honorary dignity.

The prevailing method of selecting mayors in Europe is election by the municipal council. That method is followed in Great Britain, France (except in Paris), Germany, the large cities of Italy, and the small towns of Spain; but in Germany the choice must be confirmed by the central government of the State. Appointment by the central government is the system in Belgium, Holland, Denmark, Norway, Sweden, towns of less than 10,000 population in Italy, and cities of over 6000 population in Spain; but in Belgium and Italy the appointment is limited to members of the municipal council, and in Sweden the council presents three nominations, from which the appointment is made. (In Paris, the two prefects who perform the functions of mayor are appointed by the central government.) Election by the council is also the system in the British self-governing colonies. In the United States there are some survivals of the English system of election by the council in Tennessee; but the mayor is almost universally elected by popular vote, a 
method followed in no other country. Generally in such elections the person receiving the largest number of votes is elected; but in Providence a majority vote has been required, and as a result triangular contests have been frequent, necessitating second ballots, at which "deals" between candidates have been alleged. It would seem, however, as if such a rule would encourage independent candidates, and allow every candidate to stand on his own merits, whereas at present it is often a question with many voters of choosing the lesser of two evils.

Some special qualifications required of mayors may be noted. In most countries he must be either a resident or a taxpayer; but in the United States there is a rigid residence requirement, which excludes large taxpayers and business men who live beyond the municipal limits. In Great Britain the rule is that any occupier of premises who lives within fifteen miles of the city is eligible; and in France any taxpayer is eligible to the council, and as a member of the council to the mayor's office. In Germany there is no residence requirement, but the burgomasters must be persons who have taken the professional training for administrators, and in practice the burgomasters are frequently elected by promoting an official in another city. Dr. Forckenbeck, mayor of Berlin before 1892, was called there from the similar position in Breslau; and upon his death the mayor of Danzig was mentioned for the post, although the council selected one of the Berlin magistrates. The mayor of Leipzig was formerly deputy mayor of Dresden.

In England the mayor is chosen annually, and changes are frequent; but in continental Europe, where the position carries with it large powers, the term is always of much longer duration. In France it is four years; in Holland, six years; in Belgium the Crown appointments are for an indefinite period. In Germany appointments for twelve years are the general rule, but in a number of cases the appointment is for life, sometimes after a few years on probation. The life tenure exists in Munich, Leipzig, Dresden, Hanover, Stuttgart, Chemnitz, and some smaller cities. ${ }^{1}$ In

1 Shaw, Continental Europe, p. 319. 
colonial times and during the early decades after the American Revolution, long terms for the mayors of American cities were not unknown. Thus in New York before 1775 mayors frequently held office for ten years, and in the Federalist days Richard Varick was mayor for twelve years. Under the first charter of New Haven, Conn., the mayor, who was elected by the people, ${ }^{1}$ held office during the pleasure of the General Assembly of the commonwealth; and during the forty-two years until 1826, when the provision of the charter was changed, the city had only four mayors, two of whom died in office. At the present time, however, American mayors hold office for brief terms. In New England, and in small towns elsewhere, annual elections are the rule. The two-year term is the one generally adopted by large cities, and now prevails in New York (after 1901), Chicago, Boston, Detroit, San Francisco, Baltimore, Cleveland, Newark, Omaha, Minneapolis, Denver, Milwaukee, Indianapolis, Richmond, Salt Lake City, Seattle, Atlanta, New Haven, Wilmington, Del., and Bridgeport, Conn. A few cities have longer terms for the mayor; it is four years in Philadelphia, St. Louis, Buffalo, New Orleans, and Louisville, as it was also in New York from 1897 to 1901 ; it is five years in Jersey City, and three years in Cincinnati.

The payment of regular salaries to mayors is a general feature of German and American municipal government in large cities, and in accordance with the importance of the position the salary is the highest to any municipal official. The mayor of Berlin receives $\$ 7500$ a year; those of Frankfort, Cologne, and Breslau $\$ 6250$ (25,000 marks) each; and in smaller cities smaller sums are paid. The mayor of New York city receives $\$ 15,000$ a year, the largest amount for any city, and larger than the salary of the governor of the state. The mayor of Philadelphia has $\$ 12,000$ a year ; of Boston, $\$ 10,000$; of Chicago, $\$ 7000$; of New Orleans, $\$ 6000$; of St. Louis, Baltimore, Denver, and Detroit, $\$ 5000$ each ; of San Francisco, $\$ 4200$; and of Minneapolis, $\$ 2000$. In England the council is authorized to appropriate money for the 
mayor; but sums thus appropriated go to reimburse him, and that in many cases only partially, for the heavy expenses of the office for dinners, receptions, and the like. The salaries of the prefects of Paris are $\$ 8000$ and $\$ 10,000$. But the French maires receive no salaries, although they have a significant perquisite. Immediately after the elections the maires in each department are given an elaborate reception by the department officials. This is given to secure the good will of the maires toward the national administration, and is said to be very effective in making them loyal to the supervising authorities at Paris. ${ }^{1}$

Power to remove the mayor is possessed by the central governments in some countries where they have no direct control over the selection. In France mayors may be suspended for one month by the prefects; the suspension may be extended to three months by the minister of the interior; and they may be removed by decree of the president, and such a decree renders the removed mayor ineligible for reëlection for one year. In Michigan the mayors of all cities, and in New York the mayors of most important cities, may be removed by the governor of the state for cause, which is held by the courts to require definite charges and an opportunity granted the accused to be heard in reply. The statutes of Illinois and Alabama provide for the removal of mayors by the judicial courts for certain causes. In the absence of special provisions the common law gives to the corporation the power to remove a corporate officer for reasonable and just cause ; and it has been held in this country that this power may be exercised by the representative and governing body of a municipal corporation. ${ }^{2}$

\section{POSITION AND POWERS OF THE MAYOR}

In all countries the mayor is the official head of the municipal government; and he is also the local agent of the central government, especially in regard to police matters. In

1 Wilcox, City Government, p. 190.

2 Langdon vs. New York, 27 Hun, p. 288. 
France, Italy, Belgium, and in Central Europe generally, his powers as agent of the central government are sharply distinguished from those as head of the local corporation, and in the former he is subject to strict supervision and control. In English-speaking countries, however, this distinction is not always clearly emphasized.

The special powers and duties of the mayor may be divided into three classes : 1 , those relating to the municipal council and local legislation; 2, those relating to the various administrative services; and 3 , those of a judicial character.

\section{Legislative Powers}

Under the English system, the mayor is a member and presiding officer of the council, and possesses the routine powers of a presiding officer, but nothing like the extraordinary powers of the speaker of an American legislature. As a member of the council, he serves on committees and is usually chairman of some committees, and thus takes an active part in the departmental administration; but his position as presiding officer prevents him from entering actively into the discussions of the council. His only other power in this field is that of calling special sessions of the council. $\mathrm{He}$ has no veto power over council ordinances, and no special power of initiating measures.

In France the mayor is also a member and presiding officer of the council, and has no veto power over its acts; but his influence is greater than that of the English mayor, on account of his complete control over the administrative services, while he also has the special duties of preparing the provisional budget for the consideration of the council, and of enacting police ordinances without the approval of the municipal council. Under the German system, the mayor is neither a member nor the presiding officer of the elective council, and his individual control over the council is not marked; but the board of magistrates, of which he is the chief, exercises a significant power - that of initiating measures for the council-and in addition exercises the 
authority to elaborate the council ordinances, and to negative a council act on the ground of illegality, subject to appeal to the higher authorities.

Early American mayors had powers over the councils similar to those of the English mayor; but later development has increased his influence, in some respects beyond that of the European mayors. Although the mayor is seldom chosen by the council from among its members, in a large number of small cities the popularly elected mayor is presiding officer of the council, and this is also the case in Chicago. In all the other large cities, however, the mayor does not occupy this position. As presiding officer, the mayor usually has a casting vote in case of a tie. In most cities the mayor has also the power to call special meetings of the council. The characteristic features of the American mayor in his relations to the council are those which differ from the English system. As a rule, when the mayor is anything more than the presiding officer of the council, he is required to submit to the council messages as to the condition of the city and work of the administrative departments. But such messages resemble those of the President to Congress, and of state governors to the legislatures, in that they simply make recommendations, and do not initiate measures in the council, and the mayor's powers in this respect are less extensive than those of the Prussian executive board.

Wn the other hand, the American mayor has an important power over council acts, which is not possessed in any other country, in his limited veto.) Every ordinance or resolution of the council must be submitted to the mayor for his approval; if he signs an ordinance, it becomes a law; if he disapproves and vetoes an ordinance, it must ordinarily be again passed by the council, by a two-thirds or larger vote, to become a law. This veto power may be exercised, not merely for unlawful acts, but at the discretion of the mayor; and in several respects it is a more extensive power than that possessed by the President or state governors. In most of the large cities, and many of the smaller ones, the mayor may 
veto separate items in appropriation bills. In a number of cases a larger vote than two-thirds is necessary to overrule the veto. In Baltimore a three-fourths vote is required; in New York a five-sixths vote is required to overrule the mayor's veto of an item in the appropriation bill. In a few cases the mayor has only a suspensive veto, as in Bridgeport, Conn., and a majority vote of the council will pass an ordinance over his veto. The time allowed the mayor for the consideration of council ordinances varies from three to fourteen days. It is five days in Baltimore, Philadelphia, and New Orleans, and ten days in the cities of Ohio and New Jersey.

\section{Administrative Powers}

The influence of the English mayor over the administrative services is even less distinctive than his position in relation to the general acts of the council. He does take an active part in the administration, as a member of committees, but only in the same way as other members of the council. He has no special appointing power, nor even the right of nomination to municipal positions; and he has no power of direction over the committees or administrative services as a whole. In France the maire has full charge of the administration in operation; although he does not select the adjoints, he assigns them to particular departments, and has a large and comprehensive power of direction over them. He thus has the care and management of municipal property, the supervision over municipal expenditure, the direction of public works, the making of contracts, leases, sales, acquisitions, and other business transactions of the municipality, and represents the municipality in law cases. The exercise of these powers involves the appointment of most of the salaried municipal officials, with power of suspension and removal under certain limitations. Moreover, the French maire has in his immediate charge the control of the police, acting in this field as the agent of the central government; and in this same capacity he executes the laws relating to registration of vital statistics, military 
service, assessment of national taxes, and other matters. ${ }^{1}$ In Germany the burgomaster does not have the appointing power, nor does he have the exclusive power over the whole municipal administration which the French maire exercises; but he is distinctly the head of the board of magistrates, which jointly directs and controls the whole administration. (An American mayor has, in some respects, a larger degree of individual authority over the municipal administration than this official in other countries. The tendency of recent changes is to centralize still further in his hands the control and responsibility of the whole municipal administration. In most American cities the mayor has at least the power of nominating persons for appointment to many of the leading administrative positions. 'The most frequent exception to this power is in the case of the financial officials, the treasurer and comptroller, who are generally chosen by popular vote; but in some cases (Chicago, Cleveland, and Detroit) even such officials are nominated by the mayor. There are numerous instances of other officials who are elected by municipal councils or by popular vote, but there are few large cities where the mayor does not have considerable power of nomination. Such nominations must, however, as a general rule be confirmed by the council or by one branch of a bicameral council; so that the mayor's power of appointment is far from complete, while responsibility for the persons appointed is not clearly fixed. This situation has led to the movement for conferring on the mayor the absolute power of selecting the department heads, without the necessity for confirmation by the council. This system was first established in Brooklyn in 1882, and has since been adopted in a number of cities, including $\mathrm{New}$ York, Rochester, Boston, Buffalo, Syracuse, Duluth, and other cities, especially in New York and Indiana. On the other hand, there are some important cities where the mayor's power of nomination is restricted or non-existent. In St. Louis the mayor makes nominations to the council, but in the middle of his four-year term; conse-

1 Shaw, Continental Europe, pp. 176-177. 
quently, during the first two years of his term, the officials are those appointed by his predecessor. In Providence the mayor has simply a casting vote, as presiding officer of a joint session of the two branches of the council for making appointments.

It is still a characteristic feature of appointments to municipal offices that they are for a definite term, and this method requires a definite grant of power to remove or suspend an official. With the increase in the mayor's power of appointment, there has been a similar but slower development in giving that officer the power to remove municipal officials. In most of the large cities, the mayors have now some power in this field, ranging from the right to initiate proceedings for removal, through the power to suspend or to remove for cause, to the complete power to remove at pleasure. The latter is found in only a few cases, and municipal officials have usually the right to a trial or a hearing before removal. They may, however, be suspended during the examination, and this power of suspension is usually vested in the mayor. But the power of suspension, like other disciplinary powers, must be expressly granted, and cannot be inferred from powers of regulation ; $^{1}$ nor does it generally follow, even from a grant of power to remove for cause. The power to remove for cause, which is conferred in a considerable number of cities, requires the presentation of definite charges, and a trial or formal hearing at which the official has an opportunity to reply to the charges; but if this procedure is followed, the decision of the mayor is not subject to appeal.

The mayor of Chicago has a somewhat greater power of removal, though still limited by the requirement to report the reasons for his action to the council within ten days from the date of his order for removal; and if he fails to file this statement, or if the council by a two-thirds vote of all the members disapprove of the removal, the officer is reinstated. The mayors of Boston and Philadelphia have for some years had a complete power of removing all officers whom they appoint, but must report the order of removal

1 State vs. Hudson, 44 Ohio State, p. 137. 
with charges and reasons to the city council. In 1895 the mayor of New York was given the absolute power of removal of all department heads except the board of education during the first six months of his term, in 1901 this was extended to include the whole of his term, and since 1900 the mayors of Rochester, Syracuse, Albany, and Troy have had the same absolute power of removal.

In addition to these powers of appointment and removal, American mayors have a general supervision over all of the municipal officials and departments. The extent and degree of this supervision is subject to wide variations, Where he has absolute power of removal, as in New York cities, Philadelphia, or Boston, or with such large power of removal as in Chicago, he has the practical means of directing both the general policy and the detailed action of the various departments, just as the President can control the various branches of national administration. Where, as is more often the case, he has not such complete authority, the mayor has usually the power of inspecting the books and records of the various departments, and in large cities of appointing special confidential agents for this purpose. In Philadelphia the mayor may appoint at any time and without notice three persons to audit accounts of any department ; in New York he appoints two commissioners of accounts who conduct such confidential examinations. Further supervision is exercised by investigating complaints against particular departments from public or private sources; and the mayor's office is generally a clearing-house for a large mass of complaints and inquiries.

Not only does the mayor have these powers over the municipal administration as a whole, but he has many specific powers, and exercises direct authority in particular fields. Thus he is always a peace officer, and as such is charged with the maintenance of order and the suppression of riots; and if disturbances become too strong for the municipal forces he can call on the state governor for the militia, and through him on the President for further military aid. The requisition of a mayor for militia is on the same footing as the requisition of a sheriff, and is generally 
considered as conclusive evidence that soldiers are necessary. In small cities the mayor has the direct management of the police foree, and even in Chicago and Minneapolis he has this authority, the superintendent of police acting under his directions. In St. Louis, Cincinnati, and Buffalo the mayor is ex officio a member of the police board. Another power often exercised under the direct control of the mayor is that of issuing licenses to certain trades, occupations, and celebrations, but in New York the actual work is performed by the mayor's marshal.

Other administrative duties are imposed on the mayor in his capacity as a member of various boards. Thus in New York much of his time is occupied in attending meetings of the sinking fund commissioners and of the board of estimate and apportionment.

\section{Judicial Powers}

Judicial powers other than those of removing officials for cause are conferred on the mayors only in England and the United States; while in both these countries the mayors, in the large cities at least, do not exercise these powers. The English mayor is ex officio a justice of the peace during his term of office and for one year thereafter; but the large cities have each paid police magistrates who perform the regular functions of the office. In the early American charters the mayor had always judicial powers, and the mayor's court had not only summary police powers but a considerable criminal and civil jurisdiction. In New York city the mayor's court has been transformed into the recorder's court, now one division of the state courts. Most American mayors are still endowed with the powers of a justice of the peace; but in large cities, which invariably have police judges, the powers are not used. In New England generally, and also in Chicago, St. Louis, San Francisco, and Louisville, the mayor has no judicial powers. But in small cities the mayor's court is still in active existence in many states, especially in Indiana, Iowa, Delaware, and the Southern states. The mayor's judicial powers are of most importance in Indiana cities, where a daily court is held. 


\section{CHAPTER XX}

\section{Proposed Plans of Municipal Organization}

This discussion of municipal organization shows the great variety of forms that exist, not only in different countries, but more particularly in the various states and cities of the United States. It has indeed been a marked characteristic of American municipal government that there has been a constant process of change in the form of organization - socalled charter tinkering - much of it in the effort to improve municipal government; whereas in other countries the general principles of municipal organization have been permanent, and public discussion of municipal affairs has been directed in the main to the operations and activities of the government. And it has been suggested that if less attention were given to charter changes in American cities, improved municipal conditions would be obtained more speedily.

Permanence in municipal organization is undoubtedly a factor of prime importance in securing the best municipal government; but it is impossible to abandon at once all discussion of municipal organization and to accept the existing variety of arrangements as permanent. So long as the system of enumerated powers and special legislation is continued, there must constantly be additional legislation for city government; while the system of special acts and the prevailing diversity of organization in this country tends to promote additional changes, which in general are adopted for some immediate and local purpose, - worthy or unworthy in itself, - but without reference to any general plan of government. Before anything like permanence in municipal organization can be attained, it is necessary to study the 
question, not with reference to particular cities and immediate ends, but for all classes of cities, and to frame a scheme adapted to varying conditions.

Such a general scheme of municipal organization has been drawn up by a committee of the National Municipal League, and adopted by the League under the title of A Municipal Program. This committee was composed of Horace E. Deming of New York, George W. Guthrie of Pittsburg, Charles Richardson of Philadelphia, Frank J. Goodnow of New York, Leo S. Rowe of Philadelphia, Albert Shaw of New York, and Clinton Rogers Woodruff of Philadelphia. All had long been interested in problems of municipal government, and had given a great deal of attention to the subject; while their special work in framing the Municipal Program extended over three years. This Program, then, as a serious attempt to frame a general scheme of municipal organization, is deserving of examination, and may also be used as a basis for presenting criticisms and divergent plans.

The Program consists of certain proposed amendments to state constitutions, together with a proposed municipal corporations act. The proposed constitutional amendments are five in number : -

I. Relating to the suffrage and elections, requiring a system of personal registration of voters, secret voting, the separation of municipal from national and state elections, free nominations, and the abandonment of the party group system on ballots at municipal elections.

II. Prohibiting the legislature from passing any private or local bill granting exclusive privileges, immunities, or franchises.

III. Provisions relating to municipal powers and organization :-

1. A city's streets and public places are declared inalienable except on a four-fifths vote of the council; their use must be for a limited term (twenty-one years), with stated financial reports of the grantee and the right of the city to inspect his books as a condition of the grant. 
2. Imposing limitations on the tax rate and debt of municipalities, but excluding from the debt limit debt incurred for temporary revenue or for revenue-producing undertakings.

3. Authorizing cities to establish direct legislation, or minority or proportional representation in municipal elections.

4. Municipal accounts to be uniform, and to be submitted to state authorities.

5. Cities to be authorized to establish minor courts.

6. General rules of organization : mayor and council to be elected and removed by popular vote; the mayor to have absolute power of appointment except of the comptroller; administrative officers to have indefinite terms; subordinate service to be selected by competitive examination.

7. General grant of power to cities, and limitations on special legislation.

8. A general municipal corporations act to be passed, applicable to all cities which adopt it by popular vote.

IV. Cities of over twenty-five thousand population authorized to frame charter by a locally elected board, and to adopt it by popular election.

V. Regulating the use of petitions.

The proposed municipal corporations act consists of seven articles, and is thirty-eight pages in length. In the first article is defined the procedure for the incorporation of a city under the act, or the extension of its boundaries, each depending on a popular vote in the district concerned. The second article deals with the powers of a city, as follows : corporate powers; powers to enact ordinances " necessary to protect health, life, and property, to prevent and summarily abate and remove nuisances, and to preserve and enforce the good government, order, security of the city and its inhabitants," with fines and penalties; full powers connected with the streets, waterworks, sewers, and to regulate the construction of buildings ; power to establish, maintain, and regulate wharves, docks, harbors, and ferries, markets and abattoirs, workhouses, prisons and reformatory institutions, hospitals and charitable institutions, schools, museums, li- 
braries and other institutions, and minor courts; regulates contracts and the granting of street and other franchises; a general power to levy taxes and special assessments, and to borrow money; a requirement of uniform accounts and reports; the city to act as the local agent for the enforcement of the state laws, except as other officers may be provided by the general laws applicable to all the cities of the state; all of these powers to be subject to the supervision and control of state administrative officers.

Articles 3, 4, 5, and 6 treat of the municipal organization. The mayor is to be selected by popular vote for a two-year term, and is to be subject to removal by the governor on charges and after a hearing. He is entitled to be present at the meetings of the council, and to speak, but has no vote. $\mathrm{He}$ has the limited veto power over council ordinances, is to prepare and submit the annual budget, and is to appoint all administrative officers, and also subordinate officers from a list of those who have passed the competitive examinations, and has the power to remove the same upon stating reasons.

There are very few provisions relating to the organization of the administrative departments, as their number must differ according to the size of the city and the scope of the undertakings. The only department head specifically named is the city comptroller, who is to be elected by the council for an indefinite term, and may be removed by the council. His accounts will, moreover, be audited by a state officer. Other departments will be established and organized by the council ; or may be determined by the locally framed and adopted city charter in cities of over twentyfive thousand population. The regulation of appointments to the subordinate and technical services is regulated in considerable detail. There is to be in each city a municipal civil service commission of three or more members, appointed by the mayor, who are to classify the positions, provide competitive examinations, prepare eligible lists, make probationary appointments, and promotions, with power to enforce their regulations. No municipal officer or employee 
may be removed for political reasons, and any one removed must be given a written statement showing the reasons for removal ; while all appointments, except temporary and probationary appointments, are to be without fixed terms, and subject to the pleasure of the mayor.

The council is to be composed of a single chamber, the members elected, one-third every two years, for six-year terms. Under the act they are to be chosen on general ticket, but the constitutional amendment authorizes the council to establish minority or proportional representation, and cities which frame their own charters could arrange for large districts. The council can exercise all the powers conferred on the city, subject to the veto of the mayor. Specifically, it has power to establish municipal offices, the incumbents to be appointed by the mayor; to elect the comptroller; to regulate the assessment, levy, and collection of taxes; and to appropriate money for defraying the expenses of the city government; but it has no power to increase the mayor's budget. The final article of the proposed act contains general provisions in regard to legal actions by citizens against municipal officials, nominations for municipal offices, and petitions.

The leading characteristics of this proposed system of municipal organization are : 1 , the disappearance of detailed enumerated powers ; 2, local charter legislation for cities ; 3 , the mayor's complete authority and responsibility; 4 , restrictions on political patronage ; and 5 , the position of importance given to the council. Except the first, all of these features are in operation in some parts of the United States, and most of them are approved by all students of municipal government. The first and second features are intended to abolish the constant interference of state legislatures in municipal affairs; which is everywhere denounced as a continual source of misgovernment. The system of locally framed and adopted charters is said to operate well in Missouri, California, and Washington. It gives to the charter the character of a fundamental and permanent law, which is not true of special legislative charters, and at the same 
time permits of special features in municipal organization adapted to local conditions. The complete authority of the mayor over the administration is directly in line with recent tendencies; and such centralization at least secures a definite responsibility, and tends to secure for the position of mayor a stronger man, since he is given power and opportunity to accomplish something. The system of competitive examinations for subordinate positions is applied from the national and a few municipal governments, where it has proved effective in reducing the evils of political patronage. The indefinite terms for the higher officials and the prohibition on removal for political reasons are expected to secure more permanence in municipal organization.

In advocating the restoration of the municipal council to a position of importance, the Program goes counter to recent tendencies in this country, and also to the opinions of many others interested in the improvement of municipal government.

The defence of the council is based on the distinction between municipal legislation or policy, and municipal administration. Under the present system municipal legislation is to a large extent decided by the state legislatures, and by administrative authorities ; and in cases where the weakening of the council has gone farthest, the whole field of municipal policy is controlled in this way. Since it is the avowed object to reduce the legislature's influence over questions of local policy, if the municipal council is to remain without powers or to be abolished, all matters of municipal legislation would be decided by administrative authorities. Under the present system administrative officers with powers of local legislation are to a large extent elected by the people, who thus assume some responsibility for the decisions on questions of policy; but in the proposed plan all such officers are to be appointed, and are intended to be permanent, so that there would be no direct popular control over their actions in determining municipal policy.

As to the character of the council, it is hoped by conferring important powers, by abolishing the system of artificial 
single-member districts, and by establishing longer terms, to secure the election of a better class of members. It is rather strange that the argument from example was not used by citing the case of Chicago, where the council has important powers, and where it has been found possible to elect a body of which a majority are well qualified to fill the position.

Those who oppose these measures to revive the council have their strongest arguments in the character of the persons now chosen to the municipal councils, and maintain that there is no reason to expect the election of a council of leading citizens under existing social and political conditions. Election on general ticket, it is claimed, will make a body in no way more representative of the people than the mayor, while in character and capacity the single members will still continue to average below mediocrity. In regard to the distinction between questions of policy and administration, one writer ${ }^{1}$ takes the ground that this must in any case be in large measure determined by the advice of the administrative officials ; and he also holds that there is not the need in municipal government for a legislative body to defend political liberty, as that is already guaranteed by the state and national legislatures. This writer seems to believe in the complete abolition of the council ; and as a means of controlling the spending departments, advocates the continuation of the board of estimate as it has existed in New York, composed of several officials who are at the head of departments not interested in the spending of money, of whom the comptroller and other officers have been chosen by popular vote. Such a board in some respects resembles a small council elected on a general ticket, but it has some important differences, namely, that the several members are elected for definite departments which require special qualifications, and that they are not directly interested in expenditures.

In sharp contrast with this view is the position taken by another writer ${ }^{2}$ in favor of the system of the complete supremacy of the council over the whole field of munici-

1 H. DeF. Baldwin, Municipal Affairs, III, 11.

2 E. D. Durand, Political Science Quarterly, XV, 426, 675. 
pal government. Such a solution of the problems of municipal organization had previously been tentatively suggested by Dr. Albert Shaw, ${ }^{1}$ who pointed out that it was as logical and more democratic to centralize power and responsibility in a council than in a single official. "It would seem a little strange that the one school of reformers should not have been earlier opposed by another which would advocate the concentration of authority and responsibility on the council. Logically, the mayor must eventually swallow the council or the council must swallow the mayor, if political forces are to be accorded some degree of natural play; and the oneman power is on the decline in this age. . . English, Scotch, and Irish municipal government is simply government by a group of men who are to be regarded as a grand committee of the corporation - the corporation consisting of the whole body of burgesses or qualified citizens. . . . If such a local government cannot be trusted, the fault is with popular institutions. It is quite certain to be as good a government as the people concerned deserve to have. The location of responsibility is perfectly definite."

Mr. Durand, however, is satisfied with no such suggestions, but boldly advocates the policy of an all-powerful council. To the argument of past experiences with councils, he argues that the demoralization of councils in character followed, and was more probably a result than a cause of the weakening of their powers ; and cites the experience of cities under centralized mayors to show that this system is by no means altogether satisfactory. He discusses the experience of England, France, and Germany to show that a council system gives far more satisfactory municipal government than the system in vogue in America; and that so far as conditions are more unfavorable in this country - as regards the suffrage, the intelligence and the uniformity of the electorate, the political spirit of the people, and the attitude of the parties - the remedy lies in changes adopted with reference to those conditions, and not in the centralization of power in the hands of the mayor. To those who advocate

1 Municipal Government in Great Britain, p. 63. 
a division of authority between mayor and council, he replies, on the same lines as the advocates of the all-powerful mayor : that in municipal government there are no fundamental rights at stake to require a system of checks and balances, while divided authority means confused responsibility; that in municipal affairs it is peculiarly difficult to distinguish between legislative and administrative functions; that there is no reason for excluding the council from the latter; and that efficiency is promoted by the coopperation rather than by the separation of the two departments of government. Choosing between an all-powerful mayor and an all-power느. ful council, he selects the latter for these reasons: 1 , if the council is the chief authority, able men will be attracted and elected to it, especially if the single-member district is abolished, while if the mayor is the controlling power, a bad mayor is as likely to be elected as a good one; 2, discretionary authority is better exercised by a board than by a single individual, on account of its broader knowledge, its representation of different interests, and the continuity of policy under a system of partial renewal ; and 3, the responsibility of the council to the people is at least as definite as that of the mayor, on account of the publicity of its actions.

Both of these extreme views probably go farther than the writers themselves would be willing to follow. The advocates of the mayor's authority would hardly be willing to let a single official decide such questions as the municipal purchase of street railways or the sale of municipal waterworks to a private corporation; and if the state legislatures are no longer to control the decision of municipal policies, it would seem that there must be a representative deliberative body to discuss and decide such matters. The suggestion that the board of estimate act in this capacity admits the necessity for a council of some kind. On the other hand, an all-powerful council means necessarily the abolition of the mayor's veto power and would not be consistent with a popularly elected mayor, although these are distinctive and almost universal features of American municipal government. Moreover, the system of checks and balances in American government is 
one too deeply rooted to be overthrown. The plan of the Municipal Program avoids these extreme and almost revolutionary proposals, and follows closely the lessons of experience and the tendencies of American municipal development in the past.

Accepting the view that there should be both an elected mayor with a large range of authority, and also a council, there remains the difficult problem of a satisfactory organization for the council. To the writer, the single-member district with artificial and changeable boundaries, and the general ticket system, are alike objectionable. But there could be established a system of permanent districts, recognizing the main natural divisions of the city, each electing a number of members roughly in proportion to population. Such a system would make it difficult to gerrymander districts, and even under the present system of voting would secure representation to more than one party. It is also adapted to plans of proportional representation. In the election of mayor, an absolute majority of votes should be required at the first ballot, so that a candidate may not be chosen who is supported by a minority of the voters. 



\section{INDEX}

Abattoirs, 307-309, 323.

Academies, 208-212.

Adelaide, 156, 276.

Administrative officials, 136-143, 181, 203-206, 219, 268, 269, 399-410, 425.

Administrative organization: police, 136142 ; fire brigades, 156 ; public health and safety, 181 ; public charities, 185190 ; education, 202-206; public works, 268-269; finances, 359-371.

Adulteration, food and drugs, 164, 168.

Agamenticus, Me., 72.

Aix-la-Chapelle, 287.

Alabama, municipal or ganization, 414.

Albany, 72, 74, 75, 97, 135, 137, 155, 190, $230,233,273,277,292,307,309,336$, $405,420$.

Alcalde, 411.

Alexander the Great, empire of, 7-9.

Alexandria, 8, 11, 16, 20, 280.

Allegheny, Pa., 152, 190, 209, 224, 244, 285, 295, 307, 397.

Allegheny, river, 244.

Allotments, 193, 324.

Alsace-Lorraine, 346.

Altona, 267, 310.

Altoona, Pa., 253.

America, discovery of, 30 .

Amiens, 163.

Amsterdam: 16th and 17th centuries, 35 ; fire brigade, 154; schools, 214; sewers, 251 ; lighting, 281, 283; telephones, 291; street railways, 293; ferries, 301 ; docks and harbors, 305 ; expenditures, 320, 329; debt, 332.

Amusements, public: in ancient Rome, 14 ; modern cities, 323.

Ancient cities, 3-18.

Annapolis, Md., 72.

Antioch, 8, 11, 16, 280.

Antwerp, 34, 37, 154, 214, 221, 222, 240, $305,308,332$.

Appointment, power of, 417, 418, 425 .

Aqueducts. See Waterworks.

Argentine, cities of : population, 122; police, 139, 148. See also South America.

Arlington, Mass., 276.

$$
2 \mathrm{~F}
$$

Arnheim, 214.

Arnold Arboretum, 265.

Art galleries, municipal, 221, 223.

Asphalt pavement, 232, 234.

Assessment of taxes : Great Britain, 348 350, 370; United States, 352, 361.

Assyria, cities of, 4.

Athens, 5, 6, 7, 10, 223, 227.

Atlanta, Ga., 155, 356, 377, 379, 380, 413.

Audit of municipal accounts : United

States, 361-363; France, 366-368; Italy, 368; Germany, 369; Great Britain, 370-371.

Augsburg, 27, 30, 36, 278.

Australia, cities of: population, 122; police, 138; fire brigades, 156; waterworks, 276; lighting, 284 ; street railways, 298; docks and harbors, 305 ; markets, 309 ; revenues, 335 .

Austria, cities of : population, 121, 122 ; police, 140, 141, 148; loan offices, 195; savings banks, 198; museums, 221; theatres, 223; lighting, 283; docks and harbors, 305 ; organization, 378 , 379 ; suffrage, 382 .

Avignon, 194, 242.

Azti, 283.

Babylon, 3, 4, 242.

Babylonia, cities of, 4 .

Baden, savings banks, 197.

Bagdad, 20.

Baltimore, Md. : colonial times, 77 ; first charter, 79 ; elective mayor, 82 ; population, 86 , 101 ; police, $90,100,133$; fire brigade, 152, 155; health department, 167, 174; charities, 189, 190 ; schools, 201, 205, 206, 209, 216; libraries, 219 ; street pavements, 233, 235; lack of sewers, 250 ; special assessments, 254 ; scavenging, 260 ; parks, 86, 263; waterworks, 86,273 ; street railways, $89,292,293,294$; wharves, 307 ; markets, 309 ; expenditures, 321 , 329 ; debt limit, 334 ; revenue, 373 ; organization, $377,379,413,417$.

Barcelona : in mediæval times, 21 ; expenditures, 329 . 
Barmen, 36, 223, 299.

Basel, 27, 30, 150, 215, 223, 281, 310.

Bath, N.C., 72.

Baths, public: ancient Rome, 13; Antioch, 16 ; mediæval cities, 29 ; modern cities, 260, 261 ; expenditures, 324; revenues, 338.

Battersea (London), 257.

Bavaria, cities of : organization, 117, 379; population, 121 ; police, 138 ; loan offices, 193 ; savings banks, 197 ; schools, $210,213,214$; revenues, 346 .

Belfast, 298, 305.

Belgium, cities of : population, 121, 122 ; police, 140, 141; charities, 186 ; loan offices, 193, 194; schools, 203, 212, 213; universities, 217; museums, 2:1; theatres, 223; parks, 267 ; lighting, 283,287 ; expenditures, 319,322 ; debts, 331 ; revenues, $336,340,345$; organization, $378,379,380,411,412$; proportional representation, 382 .

Belmont, Mass., 276.

Bergen, 28, 192, 223, 287.

Berlin : population, 118; police, 129, 134, 139; fire insurance, 150; fire brigade, 152 , 156; health department, 16t; building regulations, 177 ; charities, 187 ; employment bureaus, 192 ; allotments, 193; loan office, 195 ; savings bank, 197, 198; schools, 210, 211, 213; libraries, 221 ; theatre, 223 ; street pavements, 232,235 ; street improvements, 240,255 ; sewers, 250 ; scavenging, 256; parks, 267 ; waterworks, $274,277,278$; lighting, 281, 282, 287 ; street railways, 293,295 ; markets, 308 ; expenditures, 327 ; debt, 332 ; revenue, $338,346,347$; organization, $378,399,405,412,413$.

Berne, 27, 192, 215, 287.

Bi-partisan boards, 137-138, 407.

Birkenhead, 245, 293, 301, 304.

Birmingham, Ala., 100, 139.

Birmingham, Eng.: 17th century, 52; population, 68,71 ; police, 132 ; fire brigade, 153; health department, 161 ; building regulations, 179 ; schools, 216 ; libraries, 220; art school, 222; street plans, 240 ; sewers, 250 ; municipal construction, 254 ; baths, 260 ; parks, 266; waterworks, 274 ; lighting, 283; street railways, 293, 299; markets, 309 ; expenditures, 329 ; revenue, 336 ; organization, 378 .

Blackburn, Eng., 253.

Blackpool, Eng., 299.

Bloomington, Ill., 232.
Blue Hills, 264.

Board of estimate: New York, 94, 360; other cities, 98.

Boards of health, $66,68,157-180$.

Boards of public improvements, 269, 408.

Board system of administration : police, 137 ; public works, 268, 269; general discussion, $406-408$.

Bois de Boulogne, 262, 263.

Bologna, 21, 153, 221, 267, 283.

Bolton, Eng., 257, 304.

Bombay, 147.

Bonds, power to issue, 396.

Bootle, Eng., 276.

Bordeaux, 11, 157, 186, 252, 261, 329, 363.

Boroughs: English, 42-71; American colonial, 72-77; New York city, 403.

Boston, Mass.: colonial times, 76-77; charters, 82,88 ; population, 86,101 ; police, 100, 132-134, 137, 149; liquor licenses, 148; fire brigade, 152, 155; health department, 166, 167, 169, 170, $172,173,174$; great fire, 176 ; building regulations, 178 ; economic regulation, 181 ; charities, 189, 190 ; schools, 201, 205, 209; library, 217, 219 ; museum, 222 ; music, 224 ; street pavements, $230,232,233,234,235$; street plans, 239, 241; underground roads, 245 ; sewers, 247,252 ; special assessments, 254; scavenging, 260 ; baths, 261 ; parks, 263,265 ; superintendent of streets, 269 ; waterworks, $86,273,276$; lighting, 282 ; street railways, 292, 298; ferries, 302 ; docks, 306 ; markets, 309 ; expenditures, 321 , 329 ; debt, 332 , 334 ; revenue, 356 ; council, $377,378,379,381$; administrative officials, 401,405 ; mayor, 97 , $413,418,419$.

Botanical gardens, 263, 265, 266, 267.

Boulevards, 39, 263, 265, 267.

Bow Street Court, 130.

Bradford, 161, 216, 257, 283, 286.

Brazil, cities of: population, 122. See also South America.

Bremen, 195, 251, 253, 256, 278, 305, 382.

Breslau, 28, 115, 118, 210, 211, 223, 253, $256,287,301,332,346,347,378,399$, 413.

Brest, 267, 287.

Brick pavement, 232, 233.

Bridgeport, Conn., 209, 413, 417.

Bridges : ancient cities, 242 ; mediæval cities, 23, 242; Rialto, 242; Pont Neuf, 38, 242; modern cities, 243, 244 ; expenditures for, $323,324$.

Brighton, Eng., 286. 
Bristol, Eng., 46, 52, 161, 252, 260, 275, 298, 305.

British India, cities of, population, 122.

British towns. See Great Britain and Ireland, cities of.

Brookline, Mass., 261.

Brooklyn bridge, 243, 298.

Brooklyn, N.Y., 93, 94, 96, 165, 201, 233, 248, 418.

Bruges, 28, 29, 33, 35, 150.

Brunswick, 150, 156, 195, 223, 253.

Brussels : population in 1555,35 ; city hall, 36; fire brigade, 152, 154; employment bureau, 192; art school, 222 ; theatre, 223; street plans, 240 ; scavenging, 255 ; parks, 37,267 ; lighting, 284, 287 ; markets, 308; expenditures, 329 ; debt, 332 .

Budapest : loan office, 195 ; bridges, 244 ; sewage disposal, 252; baths, 261 ; boulevards, 267 ; river improvement, 305 ; organization, 378 ; suffrage, 382 .

Budget procedure: United States, 359361; France, 363-365; Germany, 369; Great Britain, 370 .

Buenos Ayres: police, 139; fire brigade, 156.

Buffalo, N.Y.: fire brigade, 155; health department, 167, 174; building regulations, 178; charities, 189, 190 ; allotments, 193; schools, 201, 205, 209; music, 224; street pavements, 233, 234,235 ; sewers, 250 ; special assessments, 254; scavenging, 260; baths, 261; botanical garden, 266 ; parks, 268; street railways, 296; council, 377, 379, 380; administrative officials, 405, 407; mayor, 97, 413, $418,421$.

Building regulations: in ancient Rome, 13; mediæval Germany, 30; modern cities, 76, 175-180.

Bureaux de bienfaisance, 183.

Burgomaster, 411, 415, 418.

Burials, municipal, 309-310.

Burnley, 305.

Business taxes, 346, 355.

Buttrick $v$. Lowell, 143.

Cadiz, 4, 9, 33.

Cairo, 20.

Calcutta, 135.

California: special legislation prohibited, 93 ; municipal home rule, 93; state board of health, 175; school grants, 340.

Cambridge, Mass., 148, 244.

Camden, N.J., 209.
Canada, cities in : population, 121, 122; police, 140; markets, 309 .

Canals, in Venice, 23.

Cardiff, 161, 267, 298.

Carthage, 4, 11, 227.

Cassel, 221.

Catania, 297.

Cemeteries, municipal, 309, 324,338, 351.

Centimes additionels, 341, 343, 344, 345.

Central control: Roman empire, 17; mediæval times, 34,45; Great Britain, 66, 69; United States, 76, 78; France, 105, 107, 363, 366-368; Prussia, 115; police, 140, 141; charities, 70, 188; schools, 203; loans, 333 ; finance administration, 363, 366-368; appointment of mayors, 411 .

Centralization: Roman empire, 17; France, 25, 27, 40, 107; Germany, 114; police, 138, 139; education, 202; docks and harbors, 305.

Central Park, 265.

Chaldea, cities of, 4.

Charities, public: Athens, 7; ancient Rome, 14; mediæval cities, 23, 30; 16 th to 18th centuries, 37, 40; England, 70, 182, 184, 187; Germany, 183, 187; France, 183, 185; Belgium, 186; Italy, 186: Holland, 186; United States, 188-191; expenditures, 323, $324,325,327,329$.

Charity organization societies, 191.

Charles river, 244, 264.

Charleston, S.C., 77, 78.

Charlestown, Mass., 244.

Charlestown, W.Va., 232.

Charlottenberg, 293.

Chelsea, Mass., 276.

Chemnitz, 287, 382, 412.

Chicago: charters, $83,84,93$; population, 102; competitive examinations, 99; police, 90, 91, 133-135, 137; fire brigade, 152, 153, 155, 156; health department, 157, 165, 167, 168, 170, 172, 174; great fire, 175; building regulations, 178; charities, 189-191; employment bureaus, 192; schools, 201, 205, 209; library, 219; music, 224 ; street pavements, 231, 233, 234, 235; abolition of grade crossings, 241; tunnels, 245; sewers, 248, 251; drainage canal, 252 ; scavenging, 260 ; baths, 261 ; boulevards, 263; parks, 266, 268; commissioner of works, 268 ; waterworks, $86,88,273$; lighting, 285; wharves, 307 ; markets, 309 ; expenditures, 327; revenue, 337, 356; finance administration, 362; 
council, $377,378,379,383,428$; administrative officials, 400, 409; mayor, $413,416,418,419,421$.

Chicago river, 245.

Chile, cities of: population, 122. See also South America.

Christiania, 154, 192, 223, 287.

Cincinnati, O.: police, $100,134,137$; tire brigade, 152, 156; health department, $167,168,170,173-174$; building regulations, 178; charities, 189, 190; schools, 201, 205, 209; library, 219; street pavements, 233, 234; bridges, 244 ; special assessments, 254; scavenging, 260; waterworks, 273; street railways, 296 ; debt limit, 334 ; organization, $97,377,379,398,407,413$, 421.

Cities of antiquity, 3-18.

City-states: ancient Greece, 5, 6, 8; Italy, 21; Germany, 21; low countries, 34 .

Civil service reform. See Competitive examinations.

Clauses acts, 66.

Cleveland, O.: charters, $83,84,88$; police, 133, 135, 137; health department, 166, 167,174 ; building regulations, 178 ; economic regulation, 180 ; charities, 190 ; schools, 201, 205, 209; library, 219 ; street pavements, 231, 233, 234; scavenging, 260; park board, 268; director of public works, 269 ; waterworks, 273; street railways, 295; wharves, 307 ; finance administration, 362 ; council, 377, 379; administrative officials, $400,405,406,407$; mayor, $97,413,418$.

Cloaca Maxima, 245.

Close corporations: English boroughs, 47, 49; in America, 73, 78.

Clyde, river, 244, 245, 303 .

Cobblestones, 230.

Coblenz, 242, 244.

Colbert, economic measures of, 38 .

Collèges, 211.

Colleges, municipal, 217.

Cologne, 16, 28, 153, 192, 198, 210, 211, $223,235,244,251,256,287,305,310$, $332,346,413$.

Colonial boroughs, American, 72-77.

Colorado, liquor licenses, 148.

Colorado Springs, Col., 253.

Columbus, O., 155, 189, 234, 260, 377, 379.

Commissioners on English municipal corporations, 56,57 .

Committees, council, $397,400$.
Communes, rise of the, 25, 26.

Como, 283, 297.

Competitive examinations, 99, 409, 425 .

Comptroller, 361, 362, 365, 371, 401, 402, 403, 425.

Concord, N.H., 100.

Connecticut, liquor licenses, 148.

Coustance, 27.

Constantinople, 20.

Constitutional amendments, proposed in a municipal program, 423 .

Construction, municipal, 254.

Contractors : ancient cities, 6,15 ; street and sewer construction, 253, 254.

Copenhagen, 154, 267, 276, 287, 329.

Cordova, 20, 228.

Corinth, 5, 11.

Corporate powers of a municipality, 395.

Corruption: English boroughs, 59; American police, 147.

Councils: bicameral system, $79,80,82$, 83,98 ; decline, $87,89,94$; continued importance in some cities, 98 ; control of finances, 360,363 ; organization, 376,382 ; powers over organization, 383 ; legislative powers, 384-396; administrative powers, $396-398$; procedure, 398 ; proposed plan of organization, 426 ; arguments for powerful council, 427, 429 ; abolition, 428 .

County police, England, 132.

Court of Accounts, 366-368.

Crefeld, 223, 267.

Croton aqueduct, $84,273$.

Cumulative voting, British school boards, 203, 381 .

Damascus, 4, 20.

Danube, river, 242, 244, 305 .

Danzig, 28, 36, 250, 305.

Darmstadt, 346.

Dazi di consumo, 344 .

Debt limits, 334 .

Debts, municipal, 327, 329, 330-334.

Decatur, Ill., 285.

Decentralization in France, 109, 110.

Delaware, mayor's judicial powers, 421.

Deming, Horace E., 423.

Denmark, cities of : population, 121,122 ; savings banks, 199; organization, 411.

Denver, Col., 100, 135, 139, 156, 167, 181, 190, 224, 235, 377, 379, 413.

Derby, Eng., 257.

Des Moines, Ia., 231, 233.

Detective system, 146.

Detroit, Mich.: charters, 79, 82 ; indo pendent boards, 88 ; police, 89,100 , 
133, 135, 137 ; fire brigade, 152, 155, 156 ; health department, 169, 170, 174; building regulations, 178; charities, 189,190 ; allotments, 193 ; schools, 205,209 ; street pavements, 231, 234; waterworks, 273 ; lighting, 285 ; street railways, 292; expenditures, 321; debt limit, 334 ; finance administration, 362 ; organization, $377,400,413$, 418.

Dijon, 26, 162, 267.

Disinfection service, 160, 164, 171 .

Docks and harbors : ancient cities, 6,8 , 9,14 ; mediæval cities, $23 ; 16$ th to 17 th centuries, 37, 39; modern cities, 75, 302-307 ; expenditures, 324 ; revenue, 338.

Domestic system of manufacturing, influence on urban development, 32 .

Doncaster, 336.

Dordrecht, 28, 35, 251.

Dortmund, 278.

Dover, Eng., 299.

Dresden: population, 118; fire brigade, 153; charities, 187; employment bureaus, 192 ; loan office, 195 ; savings bank, 198; schools, 210, 211, 214; libraries, 221, theatre, 223; street pavements, 235 ; bridges, 242,244 ; sewers, 251, 253; scavenging, 256; parks, 267 ; waterworks, 278 ; lighting, 281, 282, 287; burials, 310 ; debt, 332 ; revenue, $338,346,347$; organization, $378,382,399,412$.

Dublin, 135, 179, 267, 283, 298, 305.

Dubuque, Ia., 97, 244.

Duisburg, 221, 244.

Düsseldorf, 221, 256.

Duke of York's laws, 352.

Duluth, Minn., 234, 284.

Durand, E. D., 429.

Dust destroyers, 257.

Eastbourne, Eng., 286.

East River, 243, 301.

Economic regulation: mediæval cities, 30 ; English boroughs, 46; modern cities, 180-181.

Edinburgh, 71, 179, 241, 267, 274.

Education: Athens, 7; ancient Rome, 14 ; mediæval cities, 31 ; 16 th century, 37; modern schools, 203-217; colleges, 217; libraries, 217-221; museums, 221, 222 ; music and drama, 222, 223 ; expenditures, $323,324,325$, 327 , 329 ; revenues, 338 . See also Schools, Universities, Libraries, and Museums.
Egypt, cities of: in ancient times, 3; modern police, 138.

Elbe, river, 242, 244.

Elberfeld, 36.

Elections, municipal: separation from national, 101 ; councils, 381 ; administrative officials, 404; mayors, 411.

Electric lighting, 285-287.

Elevated railroads, 294, 299.

Elizabeth, N.J., 72 n., 333.

Elkhart, Ind., 139.

Elmira, N.Y., 277.

Eminent domain, power of, 279, 288, $299,393$.

Employment bureaus, 193.

England. See Great Britain and Ireland.

Ephesus, 11.

Epping Forest, 264.

Ergänzungsteuer, 346.

Erie, Pa., 219.

Essen, 267.

Essex County, N.J., 266.

Estates, municipal, 335-336.

Euphrates, river, 242.

European cities: 15 th to 18 th centuries, $32-41$; building regulations, 175,177 , 178; street plans, 239. See also under the various countries.

Evansville, Ind., 234.

Everett, Mass., 276.

Executive boards, 376, 377, 408.

Exeter, Eng., 52.

Expenditures, municipal, 317-329.

Factory system, 55.

Fairmount Park, 262.

Fall River, Mass., 100, 154, 279.

Ferries, 301-302.

Fiesole, 296.

Filtration of water supply, 277.

Finance administration, municipal : United States, 94, 98, 359-363; France, 363-368; Italy, 368; Germany, 368-369; Great Britain, 370.

Finances, municipal : Athens, 7 ; mediæval cities, 23, 24; England, 318, 322, 323, 338, 347 ; France, 319, 322, 341 ; Belgium, 319, 345; Germany, 320, 338,345 ; Italy, $320,322,325,343$; United States, $80,321,324,351$; expenditures, 317 , 329; debts, 330-334 ; revenues, $335-358$; administration, 359-371.

Fire brigades : ancient Rome, 12 ; mediæval cities, 30 ; modern development, 40, 84, 151, 155; organization in United States, 156; expenditures, $323,324,327,329$. 
Fire insurance, public, 150-151.

Fire prevention: fire insurance, 150 151 ; fire brigades, 151-156; powers of councils, 391.

Firma burgi, 43, 45, 348.

Fiscal systems, municipal : France, 341 ; Italy, 343; Belgium, 345; England, 347 ; United States, 351-357.

Fiume, 297.

Florence, 21, 22, 23, 223, 240, 242, 274, $296,297$.

Florida, liquor licenses, 148.

Fontainebleau, 263.

Food inspection and analysis: Great Britain, 161, 162; United States, 168, 169.

Fortifications: mediøval cities, 23; Ghent, 37.

France, cities of: ancient times, 11; mediæval times, 19,$20 ; 17$ th century, 38; before the Revolution, 103-104; history since 1789, 104-113; population, 108, 110, 112, 121, 122; police, 128, 140, 146; fire brigades, 153, 156; health departments, 157, $158,162,164,174$; charities, 183,185 ; loan offices, $194,195,196$; savings banks, 198; schools, 201, 202, 207, $211,213,214$; libraries, 220 ; museums, 221; theatres, 223; sewers, 251 ; baths, 261 ; parks, 267 ; waterworks, 278 ; lighting, 287; docks and harbors, 305 ; markets and abattoirs, 307, 308; expenditures, 319, 322; debts, 331, 332, 333; revenues, 336 , 341 ; finance administration, 363 ; councils, 376, 378, 379, 380, 382, 383, 397, 398; administrative officials, 399, 404, 406, 408; maires, 411, 412, $414,415,417$.

Franchises, municipal: Athens, 6 ; New York, 98; waterworks, 280 ; lighting plants, 289; street railways, 292, 294, 295, 297; others, 291; revenue from, 336 ; power to grant, 396 ; proposed regulation, 423 .

Franchise tax law, New York, 355.

Frankfort-on-the-Main, 28, 29, 117, 192, $221,223,253,267,274,278,281,282$, $283,287,298,332,346,371,413$.

Free cities in Germany, 27.

Freemen, English boroughs, 58.

Freiburg, 278.

French municipal history. See France, cities of.

Galesburg, Ill., 232.

Games, 264.
Garbage cremators, 257, 258.

Gas meters, inspectors of, 180.

Gasworks: modern cities, 281-285; expenditures, 323 ; revenues, $338,351$.

Gateshead, 305.

Gebühren, 346.

Gendarmerie, 128, 134, 140.

General municipal laws: Great Britain, 61, 63, 386; United States, 87, 93, 398 ; France, 104, 107, 108, 109, 112; Prussia, 114, 115, 116; proposed, 424-427.

Geneva, 153, 192, 215, 223, 240, 267, 287.

Genoa, 21, 240, 297.

Georgia, liquor licenses, 148.

Germanic invasions, 19.

Germany, cities of: independence from feudal authority, 27; decline, 33; 19th century, 114-120; population, $118,121,122$; police, 129,134 ; fire brigades, 153 ; health departments, 157, 164, 169; charities, 183, 187 ; employment bureaus, 192 ; allotments, 193; loan offices, 194, 195; savings banks, 197, 198; schools, 201, $207,209,213$; libraries, 221 ; museums, 222 ; theatres, 223 ; street pavements, 235 ; sewers, 251 ; scavenging, 256 ; baths, $29,260,261$; parks, 263, 267 ; waterworks, 276, 278; lighting, 283, 287 ; street railways, 293,296 ; docks and harbors, 305; markets and abattoirs, 307, 308; cemeteries, 309; expenditures, 320 ; revenues, 337,338 , 345 ; finance administration, 368,369 ; councils, $376,378,379,380$, 382, 397, 398 ; administrative officials, 399,404 , 406 , 408 ; burgomasters, $411,412,415$, 418.

Ghent, $29,33,35,36,154,192,217,287$, 310.

Gilds, 21, 32, 34, 44.

Glasgow: population, 68,71 ; fire brigade, 152; health department, 159; vital statistics, 160 ; building regulations, 176,.178, 179; schools, 216; library, 220 ; music, 223 ; street pavements, 229, 230; street plans, 240; bridges, 244; underground roads, 245 ; sewers, $247,250,253$; scavenging, 257, 258; baths, 260 ; parks, 266 ; waterworks, 273,278 ; lighting, 282 ; telephones, 291; street railways, 293, 299; ferries, 301; docks and harbors, 303 ; expenditures, 329 ; revenue, 336. Goodnow, Frank J., 423.

Grade crossings, abolition of, 241.

Grand Rapids, Mich., 155, 285, 398. 
Granite block pavement, 229, 233.

Great Britain and Ireland, cities of: in the Roman empire, 11; mediæval times, $19,42-49$; 15 th to 18 th centuries, 49-54; reform of the corporations, 55-63; municipal expansion, $63-71$; population, $46,52,55,58,65$, $71,121,122$; police, 129-132, 137, 141, 147 ; fire brigades, 153; health departments, 157, 158, 161, 171; food analysis, 161, 162, 174; poor relief, 182, 184, 187; employment bureaus, 192; allotments, 193; pawnshops, 196 ; schools, 200, 201, 203, 207, 212, 215 ; libraries, 218, 220 ; museums, 222 ; music, 223 ; street pavements, 236; street plans, 240; sewers, 250, 253; special assessments, 254 ; scavenging, 256-258; baths, 260; parks, $261,263,264,266$; waterworks, 273 , 275, 278; lighting, 282, 283, 284, 286; street railways, $293,297,298,300$; ferries, 301 ; docks and harbors, 302 ; markets, 307, 308; cemeteries, 310; expenditures, 318, 322, 323; debts, 331,332 , 333; revenues, 336, 337, 338, $340,341,347,351$; finance administration, 370, 371; councils, 375, 376, $378,379,380,382,383,385-387,397$; administrative officials, 404, 405, 406, 408; mayors, 411, 412, 415, 417, 421.

Greece, cities of : ancient, 4-7 ; population, 121, 122; police, 138; theatres, 223 ; docks and harbors, 305.

Grenoble, 196.

Groningen, 214.

Growth of cities: United States, 80, 83, $86,95,101$; Great Britain and Ireland, $46,52,55,63,65,68,71,121,122$; France, 108, 110, 112, 121, 122; Germany, 118, 121, 122 ; Statistics, 121, 122.

Guadalquivir, river, 33.

Guthrie, George W., 423.

Gymnasia, 209, 212.

Hague, The, 214, 277.

Hamburg: 16 th century, 36 ; population, 118; police, 147; fire insurance, 150; fire brigade, 153; health department, 165 ; employment bureaus, 192 ; loan office, 195; schools, 210, 211, 214; street pavements, 235 ; street plans, 240 ; parks, 267; waterworks, 277, 278; lighting, 287; docks and harbors, 305 ; cemeteries, 310 ; organization, $378,382$.

Hanover, 117, 150, 223, 251, 256, 282, 283, 287, 332, 369, 412.
Hanseatic League, 28.

Harbors. See Docks and harbors.

Harlem, 214.

Hartford, Conn., 78, 273.

Hastings, Eng., 286.

Haussmann, Baron, 240.

Havre, 162, 163, 213, 252, 363.

Heads of departments, 399-410, 425.

Health departments: development, 157165 ; abatement of nuisances, 166-168; food inspection, 168,169 ; infectious diseases, 169-172; vital statistics, 172; organization, 175 ; expenditures, 324.

Health regulations, 390 .

Herculaneum, 227.

Hesse, savings banks, 197.

High schools, 208-212.

Highways, the city: street pavements, 227-238; street plans, 238-241; bridges, 241-245.

Hochfeld, 244.

Holborn viaduct, 240.

Holland. See Netherlands.

Holyoke, Mass., 97.

Home rule: mediæval cities, 21, 28 ; France, 105; United States, 93, 99, 424. See also Self-government.

Hong Kong, 147.

Hospitals: mediæval cities, 31 ; infectious diseases, 171; France, 185; Italy, 186; Great Britain, 188; United States, 190 ; revenues, 338.

Huddersfield, 298.

Hudson, N.Y., 78, 277.

Hudson, river, 301.

Hungary, cities of : population, 121, 122 ; loan offices, 195.

Hyde Park (London), 261.

Hyde Park, Mass., 276.

Illinois : cities in, 83 ; special legislation forbidden, 92, 93; municipal elections, 101; liquor licenses, 148, 356 ; employment bureaus, 192 ; libraries, 219 ; municipal lighting, 286 ; organization, 397, 414.

Improvement schemes, 178, 240, 241.

Income taxes, 346.

Independent boards : England, 56, 63, 70, 187, 203; United States, 88, 139, 205.

Indiana: state police boards, 100, 139; municipal lighting, 286; school grants, 340 ; mayor's judicial powers, 421.

Indianapolis, 189, 190, 205, 206, 219, 260, $292,377,401,413$.

Infectious diseases, control of, 169-172. 
Iowa : municipal lighting, 286 ; mayors' judicial powers, 421 .

Ireland, cities of. See Great Britain and Ireland.

Irish constabulary, 138.

Italy, cities of: ancient times, 9, 11; mediæval times, 20; decline of, 33; population, 121,122 ; police, 140,141 ; health departments, 157, 158; charities, 186; loan offices, 193; savings banks, 197, 198; schools, 203, 210, 215 ; theatres, 223; parks, 267; waterworks, 278 ; lighting, 283,287 ; street railways. 296 ; docks and harbors, 305 ; expenditures, 319, 322, 325 ; debts, 331,332 ; revenues, 336 , 343 ; finance administration, 368 ; organization, 378, 379, 380, 405, 411 .

Ithaca, N.Y., 96.

Japan, cities of : population, 122 ; police, 147; lighting, 284 ; expenditures, 320.

Jardin des Plantes, 262, 264.

Jersey City, 167, 205, 232, 235, 266, 309, $334,413$.

Jerusalem, 227.

Judges appoint school boards, 205.

Judicial administration: in American colonial boroughs, 74 ; mayor's power, 421.

Justices of the peace, England, 129.

Kansas City, Mo., 100, 139, 148, 167, 190, 209, 231, 234, 295.

Kansas, police, 142.

Karlsruhe, 197.

Kentucky, police, 142.

Kew gardens, 267.

Kingston-upon-Hull, 48, 216, 299.

Königsberg, 115, 118.

Kopton, 3.

Laboratories, municipal: Paris, 163; American cities, 170.

Lands, municipal, 335-336.

La Reynie, 39.

Lawrence, Mass., 153, 253.

Leamington, Eng., 253.

Leeds: 17 th century, 52 ; fire brigade, 153 ; health department, 161 ; building regulations, 179; schools, 212, 216; libraries, 220 ; street plans, 241 ; sewers, 253; scavenging, 257; parks, 262, 266; lighting, 283; street railways, 296, 299; organization, 378 , 400 .

Leghorn, 21.
Legislative functions, in American colonial boroughs, 75 .

Leicester, 298.

Leipzig: mediæval times, 28 ; population, 118; fire brigade, 153 ; charities, 187 ; loan office, 195 ; savings bank, 198; schools, 210, 211; library, 221; street pavements, 235 ; bridges, 244 ; sewers, 253 ; waterworks, 278 ; lighting, 281, 282, 287; expenditures, 329; debt, 332 ; revenue, $338,346,347$; organization, 378, 382, 399, 412.

Leon, 24.

Leyden, 251.

Liability of municipalities for management of property, 395 .

Libraries : ancient Rome, 14 ; modern municipal, 217-221; expenditures, 323,324 .

Licenses: public carriages, 180 ; liquor, 148, 358; power to issue, 391.

Lichtenfeld, 295.

Liège, 217, 222, 298.

Lighting and Watching Act of 1830, 64 . Lighting, public: early history, 16, 39, $53,75,280,281$; gas lighting, 281285; electric lighting, 285-287; public aspects, 287-289; franchise terms, 289 ; expenditures, 323, 327, 329; revenues, 338 .

Lille, 26, 157, 213, 240, 261, 305, 363.

Lincoln, Neb., 206, 274.

Liquor traffic, control of, 148, 358.

Lisbon, 21, 33, 153, 223.

Liverpool: 17th century, 52; population, 68,71 ; police, 132; fire brigade, 153; health department, 157, 158, 161 ; building regulations, 176, 179; schools, 216; library, 218; street pavements, 230 ; street plans, 241; underground roads, 245 ; sewage disposal, 252; municipal construction, 254; scavenging, 257; baths, 260; parks, 262, 266; waterworks, 274, 276 ; lighting, 283 ; street railways, 293,299 ; ferries, 301 ; docks and harbors, 304 ; expenditures, 329 ; revenue, 336 ; organization, 378.

Loan offices, 193-196.

Local government boards, $69,158,188$, $370,387$.

Loch Katrine, 274.

London : in the Roman empire, $11 ; 17$ th century, 35, 51, 52, 53; population, 46 , 52, 55, 68, 71; police, 70, 130-134, 137, 139 ; board of works, 70 ; county council, $71,159,179,181,254,299$; school board, 71 ; poor law unions, 71 ; police 
judges, 130; fire insurance, 150; fire brigade, 152,155; health department, 158,161 ; building regulations, 176 ; charities, 188; library, 220; street pavements, $228,232,236$; street plans, 240 ; bridges, 242,243 ; underground roads, 245 ; sewers, $246,248,249,253$; scavenging, 257 ; baths, 260 ; parks, $261,262,264$; waterworks, 46, 49, $272,275,277,278$; lighting, 53, 281, 283 ; street railways, 293, 299; ferries, 301 ; docks and harbors, 304 ; markets, 308; expenditures, 327 ; debt, 332 ; revenue, $336,350,357$; organization, 71, 378; special legislation, 387 .

Long Island City, N.Y., 96.

Los Angeles, Cal., 253, 275, 334.

Louisiana, state board of health, 175 .

Louisville, Ky., 152, 167, 218, 234, 307, $309,334,337,356,377,380,413,421$.

Louvain, 217.

Lowell, Mass., 97, 216, 277.

Lübeck, 28, 29, 150, 278.

Lycées, 211, 212.

Lynn woods, 266.

Lyons: in the Roman empire, 11 ; mediæval times, $26 ; 17$ th century, 38 ; population, 113; police, 139; fire brigade, 153; health department, 157; charities, 186; schools, 213; library, 220; street plans, 240; bridges, 242 ; baths, 261 ; expenditures, 329 ; revenue, 343 ; finance administration, 363 ; organization, 106 , $378,399$.

Madrid: fire brigade, 152, 154; public squares, 267; expenditures, 329.

Magdeburg, 28, 118, 195, 267, 332.

Mainz, 28, 244, 305, 310, 346.

Maires, 411, 412, 414, 415, 417.

Malden, Mass., 276.

Malta, 147.

Manchester, Eng., 17th century, 52; population, 68,71 ; police, 132 ; fire brigade, 153; health department, 161 ; building regulations, 179 ; schools, 216 ; library, 218, 220; art school, 222 ; street improvements, 241 ; sewers, 250, 253; baths, 266 ; parks, 266 ; waterworks, 273, 274, 276; lighting, 281, 282 ; ship canal, 324 ; markets, 309 ; expenditures, 329; debt, 332 ; organization, 378,400 .

Manchester, N.H., 100, 139.

Mannheim, 221, 223.

Marcel, Étienne, 26.

Maréchaussée, 128.
Markets, public: mediæval Germany, 29; English boroughs, 46; American colonial boroughs, 75; modern cities, $307-309$; expenditures, 323 ; revenues, 338; 351.

Marseilles : founding of, 5 ; in the Roman empire, 10, 11 ; mediæval times, 21, 25 ; organization, 106; population, 113 ; health department, 157 ; charities, 186 ; employment bureau, 192; opera, 223 ; baths, 261 ; parks, 267 ; expenditures, 329 ; revenue, 343 ; financial administration, 363.

Maryland, police, 142.

Massachusetts : competitive examinations, 99 ; municipal elections, 101 ; police, 142, 144; liquor licenses, 148, 356 ; food adulteration, 168 ; state board of health, 175; schools, 200 , 216 ; libraries, 218 ; waterworks, 275 , 276 ; municipal lighting, 286; gas and electric lighting commission, 290 ; street railways, 292,296 ; civil service commission, 409.

Mayor: in American colonial boroughs, 73, 74; development of American, 77, $79,81,82,84,88,93,96,97$; comparative study, 363, 411-421; proposed authority, 425, 428.

Meat inspection, 163.

Medford, Mass., 276.

Mediæval cities, 19-31.

Melbourne: fire brigade, 156 ; waterworks, 276 ; street railways, 298.

Melrose, Mass., 276.

Memphis, 3.

Memphis, Tenn., 167, 218, 275, 307, 377.

Mersey, river, 304.

Mersey tunnel, 245.

Merthyr Tydvil, Wales, 253.

Metropolitan asylums board (Eng.), 188.

Metropolitan board of works, 70, 179, 248, 262.

Metropolitan boroughs, 71 .

Metropolitan district (Mass.): sewers, 252 ; parks, 264 ; waterworks, 275, 276.

Metz, 16.

Mexico, cities of: population, 122; police, 140, 145.

Mexico, city of: police, 139; lighting, 284.

Michigan: police, 142; liquor licenses, 148 ; state board of health, 175 ; municipal lighting, 286; bi-partisan boards, 408; governor's power of removal, 414.

|Middlesex Fells, 264. 
Middleton, Hugh, 272.

Milan : in mediæval times, 22 ; fire brigade, 152 ; charities, 186 ; savings bank, 198; theatre, 223 ; street pavements, 229; street improvements, 240 ; sewage disposal, 252; no parks, 267 ; street railways, 296,298 ; burials, 310 .

Militia, municipal, London train bands, 52.

Milwaukee : first charter, 83, 84; charter of 1874, 93; fire brigade, 153; health department, 167, 168; charities, 190 ; schools, 205, 209; art collection, 222; street pavements, 234 ; special assessments, 254 ; wharves, 307 ; organization, 377, 378, 409, 413.

Minneapolis, 137, 155, 189, 190, 205, 222, $231,234,235,244,266,377,379,413$, 421.

Minnesota: municipal home rule, 99; liquor licenses, 148, 356; state board of health, 175; municipal lighting, 286.

Minority representation, 381, 426.

Mississippi, river, 244.

Missouri : special legislation prohibited, 93; municipal home rule, 93 ; liquor licenses, 148; municipal lighting, 286.

Mobile, Ala., 250.

Moldau, river, 242.

Mons, 214.

Montpellier, 196.

Monts de piete, 193-196.

Morality police, 147.

Moscow: loan office, 195; sewers, 252; waterworks, 274.

Mosel, river, 242.

Munich: population, 118; fire brigade, 153; charities, 187 ; employment bureau, 192; loan office, 195; savings bank, 198; schools, 210, 211; street pavements, 235; sewers, 251, 253; scavenging, 256 ; parks, 267 , waterworks, 274, 278; lighting, 283, 287; markets, 308 ; expenditures, 320 , 329; debt, 332 ; revenue, $338,346,347$; organization, 378, 399, 412 .

Municipal activities: public health and safety, 125-181; charities and provident institutions, 182-199; education, 200-224; municipal improvements, 225-313.

Municipal corporations acts: England, 61, 63, 386; Prussia, 114, 115, 116; United States, 87, 93, 398; France, 104, 107, 108, 109, 112; proposed, 424, 427.
Municipal improvements : the city highways, 227-245; sewers and sewage disposal, 245-255; scavenging, 255260 ; public baths, 260-261; parks, 261-266; waterworks, 272-280 ; public lighting, 280-291; urban transportation, 291-302 ; docks and harbors, 302307 ; markets and abattoirs, 307-309; cemeteries, 309-310; expenditures, $323,324$.

Municipality, the Roman, 10.

Muuicipal ownership: waterworks, 273276 ; gasworks, 282-284; electric lighting, 285-287; telephones, 291 ; street railways, 297-299; docks and harbors, 302-307; markets and abattoirs, 307-309; cemeteries, 309; general discussion, 310-313.

Municipal property, 16, 335-336.

Municipal socialism, Germany, 119.

Museums of art and science, 221, 222.

Music and drama, 222-225.

Nahant, Mass., 276.

Nancy, 162, 163, 197.

Nantes, 157, 162, 363.

Naples: street improvements, 240; waterworks, 274; street railways, 297 ; burials, 310 .

Nashville, Tenn., 78, 307.

National governments, development, $27,32,40,49,114$.

Nebraska : police, 142; liquor licenses, 356.

Nervi, 297.

Netherlands, cities of: 16th century, 33-37 ; population, 121, 122 ; police, 140,148 ; charities, 186 ; loan offices, 194; schools, 213, 214; museums, 222 ; parks, 267 ; lighting, 283 ; cemeteries, 309; organization, 378, 379, $411,412$.

Newark, N.J., 190, 201, 232, 234, 266, $334,413$.

New Bedford, Mass., 216.

Newcastle-upon-Tyne, 241, 257, 260, 266, $287,305,336$.

New England, cities in: libraries, 218; commons, 262 ; organization, 377.

New Haven, Conn., 78, 135, 190, 275, 413.

New Jersey: colonial boroughs, 72; special legislation forbidden, 93; liquor licenses, 148; food adulteration, 168 ; subventions, 340 ; municipal organization, 417.

New Orleans: first charter, 79; competitive examinations, 99; police, 
137; health department, 166, 168, 174 ; charities, 190; schools, 201, 205, 209; street pavements, 231, 233; lack of sewers, 250; scavenging, 260; parked avenues, 266; waterworks, 275,277 ; ferries, 301; wharves, 306 ; markets, 309 ; revenue, 356 ; organization, 377, 379, 408, 409, 413, 417.

Newport, R.I., 78, 139.

New South Wales, cities of: police, 138, 147; lighting, 284. See also Australia and Sydney.

Newton, Mass., 276.

New York City : colonial times, 72, 74, 75 ; charters, $82,83,88,91$; population, 80, 86, 101 ; politics, $80,81,101$; police, $80,132-134,137,145$; tire brigade, 152, 155, 156; health department, 157, 165, 167, 168, 169, 170, 171, 173, 174; building regulations, 176, 177, 179; economic regulation, 180; public safety, 181; charities, 190, 191; employment bureau, 192; schools, 201, 205, 209; libraries, 219; museums, 222; music, 224; street pavements, 230, 231, 232, 234, 235; street plans, 239, 241; bridges, 243, 244 ; underground roads, 245 ; sewers, $247,248,251,252$; special assessments, 254; scavenging, 258, 259; parks, 86, 262, 265; waterworks, 84, 273 , 275; lighting, 282 ; street railways, 89 , 292, 294, 295 ; ferries, 301 ; docks, 306; municipal ownership, 313; expenditures, 80, 321, 327 ; debt, 332 , 334 ; revenue, 336 , 356 ; finance administration, $94,360,362$; councils, $378,381,398$; administrative officials, $400,403,405,406,408,409$; mayor, $96,97,413,418,420,421$; state commissions, 89, 90, 404 .

New York State: city mayors, 81, 414; development of cities, 83 ; police, 142 ; liquor licenses, 148,356 ; food adulteration, 168 ; charities, 188, 191 ; schools, 201, 203; lighting, 291; state grants, 340 ; taxation, 353, 355, 357 ; civil service commissions, 409 .

Nice, 162, 163, 192, 223, 261, 297.

Nineveh, 3.

Norfolk, Va., 72, 78, 356.

Norway, cities of : population, 121, 122 ; liquor traffic, 150; fire insurance, 150 ; schools, 212, 215 ; lighting, 283; organization, 411.

Norwich, Eng., 46, 52, 222, 266, 287.

Nottingham, $52,193,216,220, \cdot 222,253$, 257, $266,299$.
Nuisances, abatement of, 166.

Nuremberg, 28, 29, 36.

Oakland, Cal., 234.

Obligatory expenditure, French communes, 364.

Obligatory service, 120, 398.

Octrois, 7, 24, 341, 343, 344, 345, 346.

Odessa, 195.

Offensive trades, regulation of, 168.

Ohio: development of cities, 83 ; special legislation, 85, 87; liquor licenses, 148; food adulteration, 168 ; employment bureaus, 192; municipal lighting, 286 ; municipal organization, 417.

Obio, river, 244.

Oldham, 273.

Oligarchic government, 16, 27, 31, 47, 59 .

Omaha, Neb., 100, 206, 224, 231, 234, 275, $309,413$.

Omnibuses, 292.

Opera houses, 222, 223.

Oporto, 153.

Optional expenditure, of French communes, 365 .

Ordinance power: mediæval cities, 30 ; American colonial boroughs, 75; municipal councils, 384-395; administrative officials, 409-410.

Organization, municipal: Roman cities, 16; mediæval cities, 21, 31; Great Britain, 47, 61; United States, 73, $78,82,87-89,93,94,96-100,174$; France, 103-112; Germany, 115-117 ; police, 136-143; public safety, 181; school boards, 203-206; libraries, 219; public works, 268, 269; the council, 375-398; administrative officials, 399 410 ; the mayor, 411-421; proposed plans, 422-431.

Outdoor relief, 188, 190.

Oxford, 272, 305.

Padua, 283.

Palermo, 297.

Paphos, 4.

Paris: mediæval times, 26 ; population, 38,113 ; police, $39,128,134,139,146$; fire brigade, $152,155,156$; health department, 157, 162, 163, 174 ; building regulations, 177,179 ; charities, 183,185 , 186; allotments, 193; loan office, 194, 195, 196; savings bank, 198 ; schools, 213; libraries, 220; theatres, 223; street pavements, 228, 232, 235; street plans, 238, 240; sewers, $245,247,249,253$; scavenging, 255 , 256; baths, 261; parks, 262, 263; 
waterworks, $273,274,278$; lighting, $39,280,282,285,289$; omnibuses, 292 ; street railways, 293 ; markets, 307 ; expenditures, 319, 327; debt, 332 ; revenue, 342,343 ; finance administration, 363 ; organization, 106, 110, 112, 378, 398, 399, 414.

Parks : in ancient Rome, 13; mediæval Brussels, 37 ; modern cities, 261-268; administration, 208; expenditures, $323,324,327,329$.

Parliament, representation of boroughs in, $45,50,51,56$.

Paterson, N.J., 172, 275.

Pau, 163.

Pavia, 242.

Paving. See Street parements.

Pawnshops, 193-196.

Pawtucket, R.I., 253, 405.

Pennsylvania: colonial boroughs, 72 ; special legislation forbidden, 93 ; liquor licenses, 148; municipal lighting, 286 ; street railways, 296 ; organization, 397.

Pensions, U.S. federal government, 189.

Peoria, Ill., 232, 234.

Personalty assessments, 354, 361.

Perth Amboy, N.J., 72.

Perugia, 297.

Philadelphia : in colonial times, 72-76; charters, $79,82,88$; population, 86 , 101 ; police, 132-134, 137 ; fire brigade, $152,155,156$; health department, 157, 167,174 ; director of public safety, 181 ; charities, 189, 190; schools, 201, 205, 209; libraries, 219; art museum, 222 ; music, 224 ; street pavements, 230, 231, 232, 233, 234, 296 ; street plans, 238; bridges, 244 ; sewers, 250 , 251 ; special assessments, 254 ; scavenging, 260 ; parks, 86, 262, 266; director of public works, 269 ; waterworks, 273; lighting, 282, 284, 289 ; street railways, 296 ; wharves, 306 ; expenditures, 329 ; debt, 332 ; revenue, 356 ; councils, $377,378,379$; administrative officials, 405 ; mayor, $413,417,419,420$.

Phœcea, 5.

Piedmont, 158.

Piræus, 6, 227.

Pisa, 21.

Pittsburg : charters, 80, 93; fire brigade, 155 ; director of public safety, 181 ; charities, 190 ; schools, 205, 209 ; street pavements, 233, 234; bridges, 244 ; scavenging, 260; botanical garden, 266 ; wharves, 307 ; organization, 397.
Plauen, 287.

Playgrounds, 261-268.

Plural voting, 66, 69.

Plymouth, Eng., 272, 299, 305.

Podesta, 22, 25.

Police: ancient Rome, 12 ; mediæval cities, 23,30 ; Paris, 39, 128, 134, 139, 146 ; London, 53, 54, 70, 130-132, 134, 139,146 ; history, $127-134$; ratio to population, 135 ; organization, 136 ; police boards, 137; state police, 138140 ; state control, 140-141, 144; state agents in United States, 142, 143; duties of, 144-149; corruption, 147; expenditure, $323,324,325,327$, 329.

Police judges, 128, 130, 142, 405.

Police regulation, $30,75,388-390$.

Politics, in United States municipal government, 81, 91, 92, 407.

Pompeii, 227.

Poor Law Amendment Act, 184.

Poor relief. See Charities.

Population. See Growth of cities.

Port Rush, 295.

Portsmouth, Eng., 216, 305.

Portugal, cities of : 16th century, 33; population, 121, 122 ; police, 140.

Posen, 253.

Postal service, municipal, 30 .

Prague, 154, 195, 198, 242, 244, 251, 261, 283, 299, 301.

Prefects: control over municipal finances, 363,365 .

Prestations, 341, 344, 345.

Preston, Eng., 257, 287.

Private Bills: British, 387. See also Special Legislation.

Private improvements, 254, 351. See also Special Assessments.

Procedure of municipal councils, 398.

Program, A Municipal, 423-427.

Property, municipal. See Lands, municipal.

Property qualifications, 62, 382.

Property rights of nunicipalities, 394, 395.

Proportional representation, 382, 424, 426.

Prospect Park, 265.

Providence, R.I., 190, 201, 205, 209, 218, $223,234,261,277,296,309,377,379$, $412,419$.

Provident institutions: employment bureaus, 192; allotments, 193; public loan offices, 193-196; savings banks, 196-199.

Provisional Order Acts, 387. 
Prussia, citles of : population, 118, 121; police, 134, 139, 141; health departments, 164, 174; savings banks, 197 ; schools, 201, 203, 207, 209, 213 ; waterworks, 276 ; debts, 333 ; revenues, $336,345,346$; suffrage, 382 ; organization, 115-117, 379, 382, 385, 399, 405, 406.

Public Health Acts, English, 66, 69, 349, 386.

Public health and safety : police administration, 125-149; protection from fire, 149-157; health departments, 157-175 ; building departments, 175180 ; economic regulation, 180 ; administrative organization, 181 .

Public squares: ancient Rome, 13 ; 16th century, 36; modern cities, 267.

Public works. See Municipal improvements.

Quarantine, 170.

Quincy, Josiah, 82.

Quincy, Josiah, Jr., 217.

Quincy, Mass., 97, 276.

Rates, 347, 348, 351.

Reading, Eng., 304.

Reading, Pa., 155.

Receveur, municipal, 365.

Recreation piers, 265.

Reformation, influence on municipal affairs, 37, 182.

Reform of the English corporations, 5462.

Regensburg, 27, 242.

Regierungspräsident, 369.

Removal, power of, 414, 417, 419, 426 .

Revenues, municipal : ancient cities, 6 , 16 ; commercial revenue, $335-338$; subventions, 339-341 ; fiscal systems, 341-358.

Revere, Mass., 264, 276.

Rheims, 26, 162, 163, 192, 213, 221, 261.

Rhine, river, 244.

Rhode Island, libraries, 218.

Rhodes, 4, 6, 9.

Rhone, river, 242.

Rialto, bridge of the, 242.

Richardson, Charles, 423.

Richmond, Va., 73, 93, 94, 190, 284, 295, $296,413$.

Riga, 36, 154, 195, 199, 252, 302.

Rio de Janeiro, 139.

Rochester, N.Y., 97, 137, 206, 234, 309, $377,379,405,420$.

Roman Empire, cities of the, 9-18.
Rome: ancient, 11-15, 127, 227, 242; building regulations, 177; charities, 186 ; loan office, 196; theatre, 223; street improvements, 240 ; sewers, 252; baths, 13, 261; parks, 267; waterworks, 12,274 ; street railways, 297 ; burials, 310 ; expenditures, 320 , 329.

Rotterdam, 35, 153, 277, 283, 287, 301.

Roubaix, 153, 261, 267, 305, 363.

Rouen, 157, 192, 221, 240, 261, 363.

Rowe, L. S., 423.

Rugby, Eng., 253.

Russia, cities of : population, 121, 122 ; police, 136-139; loan offices, 195; schools, 202; theatres, 223; docks and harbors, 305 ; revenues, 335.

St.-Étienne, 162, 163, 192, 261, 363.

St. Joseph, Mo., 100, 139, 155, 235, 266, 275.

St. Louis : charters, 82, 93; police, 100 , 133, 137; population, 102; liquor licenses, 148; health department, $166,167,174$; building regulations, 178; charities, 190; schools, 201, 205, 206,209 ; music, 224 ; street pavements, 231, 233, 234, 235; bridges, 244 ; sewers, 250 ; special assessments, 254 ; scavenging, 260 ; parks, 268; board of public improvements, 269 ; waterworks, 273 ; ferries, 301 ; wharves, 306; expenditures, 329; revenue, 356 ; council, $377,378,379$, 380 ; administrative officials, 402,408 ; mayor, 413, 418, 421.

St. Pancras (London), 130, 286.

St. Paul, Minn., 152, 155, 156, 169, 170, $190,205,231,234,235,244,266,307$, 334, 377, 379.

St. Petersburg : fire brigade, 152 ; sewers, 252 ; ferries, 301.

Salaries: members of councils, 398; administrative officials, 405 ; mayors, 413.

Salford, 161, 216, 253, 257, 260, 267, 276.

Salt Lake City, 413.

Salzburg, 27.

San Francisco: state police board, 100, 139 ; liquor licenses, 148; health department, 168 ; employment bureau, 192 ; schools, 205, 209; street pavements, 231, 233, 234; waterworks, 275 ; docks, 306; markets, 309; organization, 377, 379, 413, 421.

Sargon, 227.

Savannah, Ga., 79, 205, 356.

Savings banks, 196-199. 
Saxony, cities of: organization, 117, 379,412 ; population, 121 ; fire insurance, 150 ; schools, 210,213 ; finances, $320,346$.

Scavenging, 12, 46, 255-260.

Scheldt, river, 35 .

Schleswig-Holstein, 369 .

School boards, independent: Great Britain, 203, 381; United States, 205.

Schools : elementary, 31, 70, 203-207; high schools and academies, 208-212; technical schools, 213-217; powers of municipal councils, 393 . See also Education.

Schuylkill, river, 244.

Scot and lot, 348 .

Scotland : organization, 61,376 ; schools, 200, 212; charities, 187 . See also Great Britain, Glasgow, and Edinburgh.

Scranton, Pa., 154, 155, 209, 235, 275, 276,397 .

Seattle, Wash., 413.

Secondary schools: high schools and academies, 208-212; technical schools, 212-217.

Seine, river, 38, 242, 249.

Self-government: mediæval cities, 21, 28; United States, 93, 99; France, 105 ; police, 142 ; health departments, 174; charities, 187, 189; schools, 203.

Seville, 33 .

Sewers: ancient Rome, 12; London, 53, 246, 248; Paris, 245, 247, 249; United States, 75, 247, 250; modern systems, 245-255 ; final disposal, 248-250, 252253 ; construction by contract, 253 ; special assessments, 254; expenditures, $323,324,327,329$.

Shaw, Albert, 423,429 .

Sheffield, 52, 161, 216, 236, 253, 267, 273, $283,293,299,309$.

Sidon, 4.

Sienna, 229.

Silesia, fire insurance, 150.

Single-headed departments : police, 137 ; schools, 205,407 ; public works, 268 ; general view, 406 .

Sinking funds, 336.

Slaughter-houses, 307-309, 323.

Snow removal, 259.

Somerville, Mass., 148, 276.

South Africa, police, 138.

South America, cities of: population, 122 ; police, 138, 140; loan offices, 196 ; markets, 309.

Southampton, 272.
South Bend, Ind., 139.

South Carolina, powers of municipalities, 395 .

South Framingham, Mass., 253.

South Shields, 305 .

Spain, cities of : mediæval times, 20,24 ; after 1500,33 ; population, 121,122 ; police, 140 ; loan offices, 196 ; savings banks, 197; organization, 378, 379, 411.

Sparta, 5.

Special assessments, $338,342,344,345$, $357,358,393$.

Special legislation: Great Britain, 55, 63,387 ; United States, $85,87,93,100$, 409 ; constitutional prohibitions, 87 , $93,99$.

Speedway, 265.

Spezia, 283, 297.

Spoils system, 80, 81, 94, 99, 312, 407.

Sports, 264.

Spree, river, 244.

Springfield, Mass., 93, 222.

Springfield, O., 153.

State boards of health, 175 .

State commissions, $89,100,139,157,174$, $401,404$.

State legislatures, influence of, in municipal government, $75,76,77,85$, $87,89$.

Statistical tables: urban population, 121, 122; vital statistics, 173 ; schools, 207, 209-212; street pavements, 236 ; street cleaning, 259 ; municipal lighting, 284, 286; markets, 308; expenditures, 318-329; debts, 331 , 332; revenues, $338,342,343,344,346,347,351$, 354,358 .

Statistics, official, 362, 371.

Stettin, 150.

Steubenville, O., 232.

Stockholm, 154, 261, 283, 287.

Strand, the (London), 228.

Strasburg, 28, 256.

Street cleaning, 12, 46, 255-260.

Street lighting. See Lighting, public.

Street pavements : ancient cities, 12, 16 , 227 ; Paris, 26, 39, 228, 236 ; mediæval cities, 29, 36; London, 50, 53, 228, 229, 232, 236 ; United States, 75, 230, 233235 ; other countries, $232,235,236$; comparative merits, 236-237; construction by contract, 253 ; special assessments, 254; expenditure, 323, $324,327,329$.

Street plans: ancient cities, 6, 8, 13; mediæval cities, 30 ; London, 50, 53; modern cities, 238-241. 
Street railways: development, 69, 89, 292-295; present systems, 295-299; public aspects, 299-300; revenues, 338.

Streets and highways, powers of municipal councils, 393.

Stuttgart, 412.

Subventions, 139, 202, 203, 339-341, 351.

Subways, 274-275.

Suffrage, municipal: Great Britain, 62 ; United States, 73, 84; France, 108, 109; Prussia, 116, 382 ; Austria, 382.

Superior, Wis., 234.

Suppression of nuisances, 390 .

Susa, 4.

Susquehanna, river, 276.

Swampscott, Mass., 276.

Swansea, 161, 305.

Sweden, cities of : population, 121, 122.

Switzerland, cities of: loan offices, 196; savings banks, 199; schools, 215; museums, 221; lighting, 283; street railways, 299 ; proportional representation, 382; organization, 378, 411.

Sydney, N.S.W.: police, 138; fire brigade, 156 ; waterworks, 276 ; markets, 309.

Syndic, 411.

Syracuse, ancient, 5 .

Syracuse, N.Y., 96, 97, 137, 190, 224, 235, $377,379,405,420$.

Taunton, Mass., 253.

Taxation: United States, 76, 84, 85, 321, 351-357, 393; Great Britain, 43, 62, 318, 347-351; France, 104, 341-343; Italy, 343, 344; Belgium, 345 ; Germany, $320,345-347$.

Technical schools, 213-217.

Telegraph, fire alarm, and police, 291.

Telephones, 291.

Tenement houses : regulation, 176 ; municipal ownership, 178, 338.

Tennessee, organization, 411.

Term of service: members of councils, 379 ; administrative officials, 406 ; mayors, 412.

Terre Haute, Ind., 139.

Texas, special legislation forbidden, 93.

Thames Conservancy Board, 304.

Thames, river, $242,245,246,248,301$, 304.

Theatres, municipal, 222, 223.

Thebes, 3, 5, 227.

'Thirty Years' War, 37.

Three-class system of voting: Prussia, 116, 382; Austria, 382. .

Tiber, river, 242.
Ticino, river, 242.

Tokio : police, 139 ; expenditures, 320.

Toledo, O., 190, 205, 206, 284.

Tolls, 244.

Toronto, 295, 298.

Toulon, 267, 301.

Toulouse, 38, 157, 163, 240, 363.

Town meetings, 76 .

Trade schools, 213, 214, 216.

Trade taxes, $346,355$.

Tramways, 69, 89, 292-300.

Transportation, urban: early history, 291-292; street railways, 292-300; ferries, 301-302.

Trenton, N.J., 72.

Trieste, 154, 283, 297.

Troy, N.Y., 97, 135, 137, 377, 379, 405, 420.

Troyes, 157, 162.

Turin, 229, 297.

Tweed ring, 93, 322 .

Tyre, 4.

Underground roads, 274-275.

Uniform municipal accounts: need of, 362 ; proposed requirement, 424.

United States, cities in : colonial period, 72-77; 19th century development, $78-102$; population, $80,86,95,101$, 121, 122 ; police, 132-134, 137, 147 ; fire brigades, 151, 154-157 ; health departmeuts, 157, 165, 169, 170, 171, 174; building regulations, $175,176,177$; charities, 188-191; employment bureaus, 192 ; allotments, 193 ; pawnshops, 196; savings banks, 199; schools, 201, 203-209, 216; libraries, 217-219; museums, 222; music, 223, 224 ; street pavements, 233-235 ; street plans, 238; street improvements, 241 ; sewers, $247,248,250,251,252,253$; special assessments, 254 , 357 ; scavenging, 258-260; baths, 261; parks, $262,263,265,266$; waterworks, 273 , 275,278 ; lighting, $282,284,285,286$; street railways, 292, 294-296, 298; docks and harbors, 305-307 ; markets and abattoirs, 307, 309; cemeteries, 310 ; expenditures, 321, 322, 325 ; debts, 331, 332, 333; revenues, 336, $337,338,351-358$; finance administration, 359-363; councils, 376, 377, $378,379,380,382,383,384,387-396$, 398 ; administrative officials, 400,404 , 406; mayors, 411, 412, 416, 418, 421.

Universities, municipal, 217.

Utica, N.Y., 96, 234.

Utrecht, 214. 
Vaccination, 169.

Varick, Richard, 413.

Venice, 21, 22, 242, 301.

Verona, 16, 229.

Versailles, 157, 263.

Veto power of American mayors, 79, 88, $416,425,430$.

Vice, control of, 147.

Vicenza, 283.

Vienna: in the Roman empire, 11; mediæval times, 27, 29, 30; police, 134, 139 ; fire brigade, 152,154 ; loan office, 195; savings bank, 198; bridges, 244 ; sewage disposal, 252; baths, 261 ; parks, 267 ; waterworks, 274 ; lighting, 281, 282; street railways, 293; expenditures, 320 ; revenue, 335 ; organization, 378 .

Vincennes, Ind., 285.

Virginia: colonial boroughs, 72; special legislation forbidden, 87 ; state board of health, 175 .

Vital statistics, 160, 172, 173.

Wabash, Ind., 285.

Wandsworth (London), 257.

Waring, George E., Jr., 256, 258.

Warsaw, 154.

Washington, D.C.: police, 135, 139; liquor licenses, 148; charities, 190; schools, 209; libraries, 219 ; street pavements, $232,234,235$; street plans, 238 ; sewers, 251 ; scavenging, 260 ; parks, 266 ; street railways, 295.

Water supply: ancient cities, $6,12,16$; mediæval cities, 29; London, 46, 50, 272, 275; Paris, 39, 273, 274; New
York, 84, 273 ; modern systems, 272278 ; public aspects, 279 ; franchises, 280 ; expenditures, 323, 327, 329; revenues, 338, 351,358 .

Watertown, Mass., 276.

Weights, sealer of, 180, 401, 402, 404.

West Ham, 216, 304.

Westminster (London), 281.

Wharves, 302-307.

Wheeling, W.Va., 232, 244, 284.

Whitechapel (London), 257.

Wiesbaden, 221.

Wilkesbarre, Pa., 276.

Wilmington, Del., 155, 413.

Winthrop, Mass., 276.

Wisconsin: special legislation prohib. ited, 99; liquor licenses, 148.

Wolverhampton, 274.

Wood pavements, 230, 234.

Woodruff, Clinton Rogers, 423.

Woolwich (London), 301.

Worcester, Eng., 52.

Worcester, Mass., 154, 172, 209, 224, 253, $261,273,290$.

Works Committee of London County Council, 254.

Württemberg, cities of: police, 138; fire insurance, 150; schools, 210.

Yokohama, 284.

Yonkers, N.Y., 261.

York, 11, 46, 52.

Ypres, 37.

Zanesville, O., 232.

Zoölogical parks, 263, 265.

Zurich, 27, 150, 215, 277, 278, 332. 


\title{
THE GOVERNMENT OF MUNICIPALITIES
}

\section{BY DORMAN B. EATON}

Cloth. 8vo. \$4.00 net

“ Mr Eaton has in this volume provided us with the best systematic treatise that is available for the American student, law-maker, or municipal reformer, upon the principles that should be observed in the framing of a city charter, and upon the position of the American city in the state, of which it is one of the minor jurisdictions. Mr. Eaton, more than any other man, has identified himself with the great cause of an efficient, non-partisan civil service in this country; and he has been a life-long student of public administration. As a lawyer and public official in times past he has had much practical experience both with the drafting of administrative laws and with their practical working. This volume is the ripe product of many years of thought, experience, and observation." - Review of Reviezws.

\section{THE AMERICAN COMMONWEALTH}

\author{
BY JAMES BRYCE \\ Author of "The Holy Roman Empire" \\ M.P. FOR ABERDEEN
}

In two volumes. Third edition, completely revised throughout, with additional chapters

Crown 8vo. Cloth. Gilt tops

Vol. I. The National Government - The State Government. pp. xix +724 . Price, $\$ 1.75$ net

Vol. II. The Party System-Public Opinion-Illustrations and ReFlections - Social Institutions. pp. 904. Price, $\$ 2.25$ net.

The two volumes in a box, $\$ 4.00$ net

"It is not too much to call 'The American Commonwealth' one of the most distinguished additions to political and social science which this generation has seen. It has done, and will continue to do, a great work in informing the world concerning the principles of this government."-Philadelphia Evening Telegraph.

"No enlightened American can desire a better thing for his country than the widest diffusion and the most thorough reading of Mr. Bryce's impartial and penetrating work." - Literary World.

\section{THE MACMILLAN COMPANY}

66 FIFTH AVENUE, NEW YORK 


\title{
MUNICIPAL HOME RULE
}

\author{
A STUDYIN ADMINISTRATION \\ By FRANK J. GOODNOW, A.M., LL.D. \\ Professor of Administrative Law in Columbia University
}

Cloth. 12mo. \$1.50 net

"A scholarly, thoughtful, and independent criticism of municipal experiences, and the plans now urged to better municipal conditions. . . . The volume is an exceptionally valuable one to close students of municipal affairs." - The Outlook.

"It is one of the finest studies in administration that has ever been offered to political students." - Chicago Inter-Ocean.

\section{MUNICIPAL PROBLEMS}

\author{
By FRANK J. GOODNOW, A.M., LL.D.
}

Professor of Administrative Law in Columbia University

Cloth. 12mo. \$1.50 net

"One of the most trenchant and scholarly contributions to political science of recent writing, remarkable for analytical power and lucidity of statement." Chicago Evening Post.

\section{THE MACMILLAN COMPANY}

66 FIFTH AVENUE, NEW YORK 

RETURN TO the circulation desk of any University of California Library

$$
\text { or to the }
$$

NORTHERN REGIONAL LIBRARY FACILITY

Bldg. 400, Richmond Field Station

University of California

Richmond, CA 94804-4698

ALL BOOKS MAY BE RECALLED AFTER 7 DAYS

2-month loans may be renewed by calling

(510) 642-6753

1-year loans may be recharged by bringing books to NRLF

Renewals and recharges may be made 4 days prior to due date

DUE AS STAMPED BELOW MAY 171935 

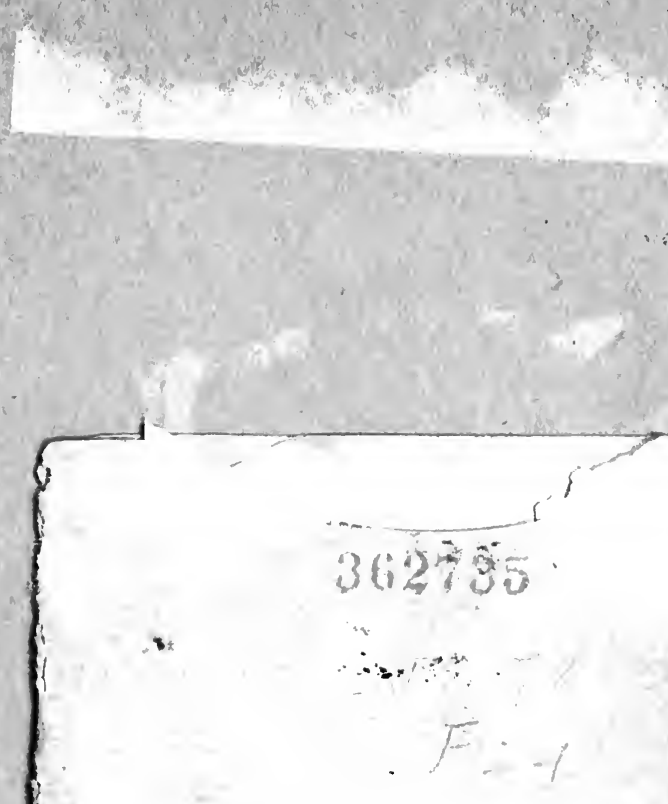

UNIVERSITY OF CALIFORNIA LIBRARY

$\mathrm{i}, \ldots$ 


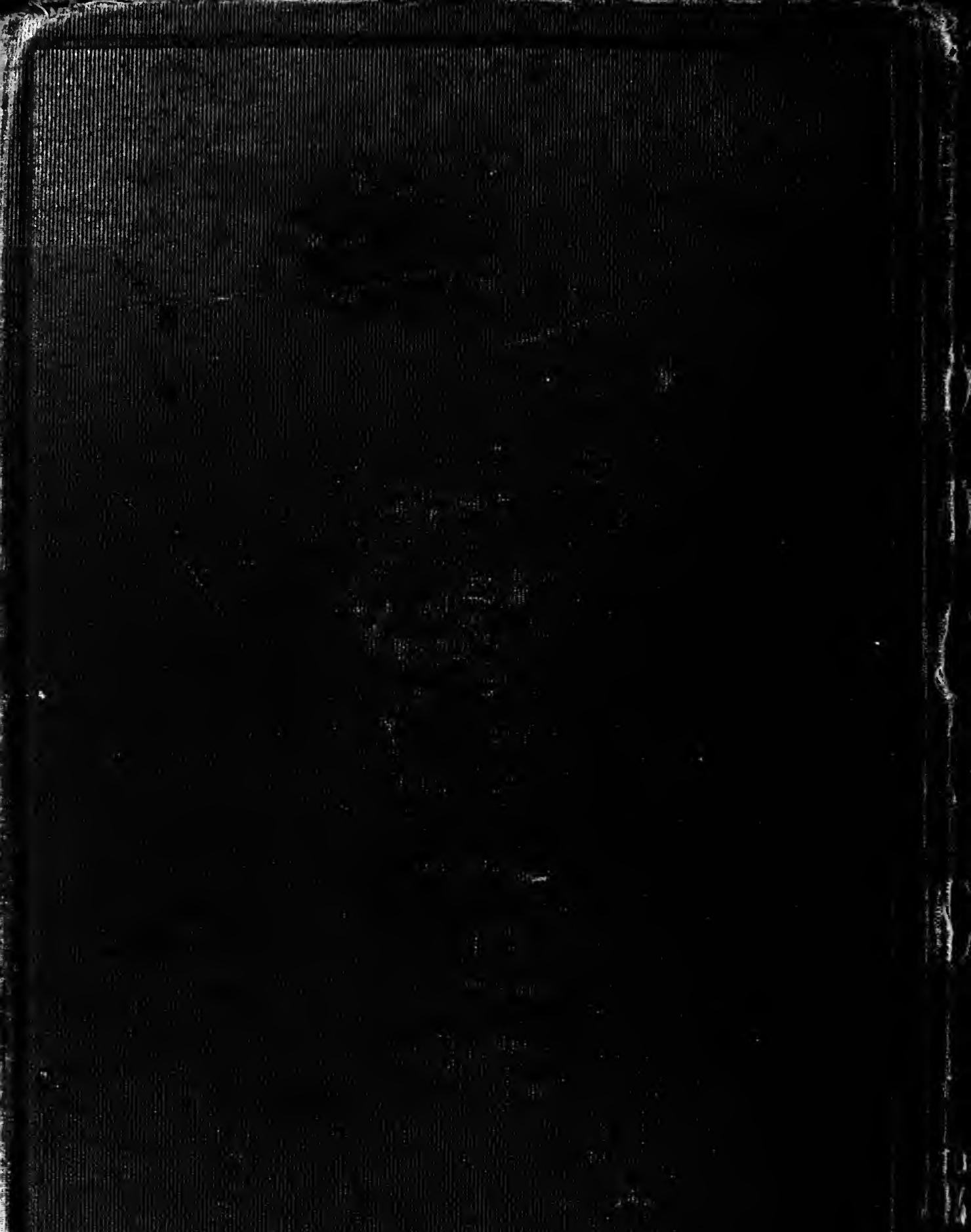

